Scott Cane

and

Owen Stantey

\section{Land Use and Resources in Desert Homelands}

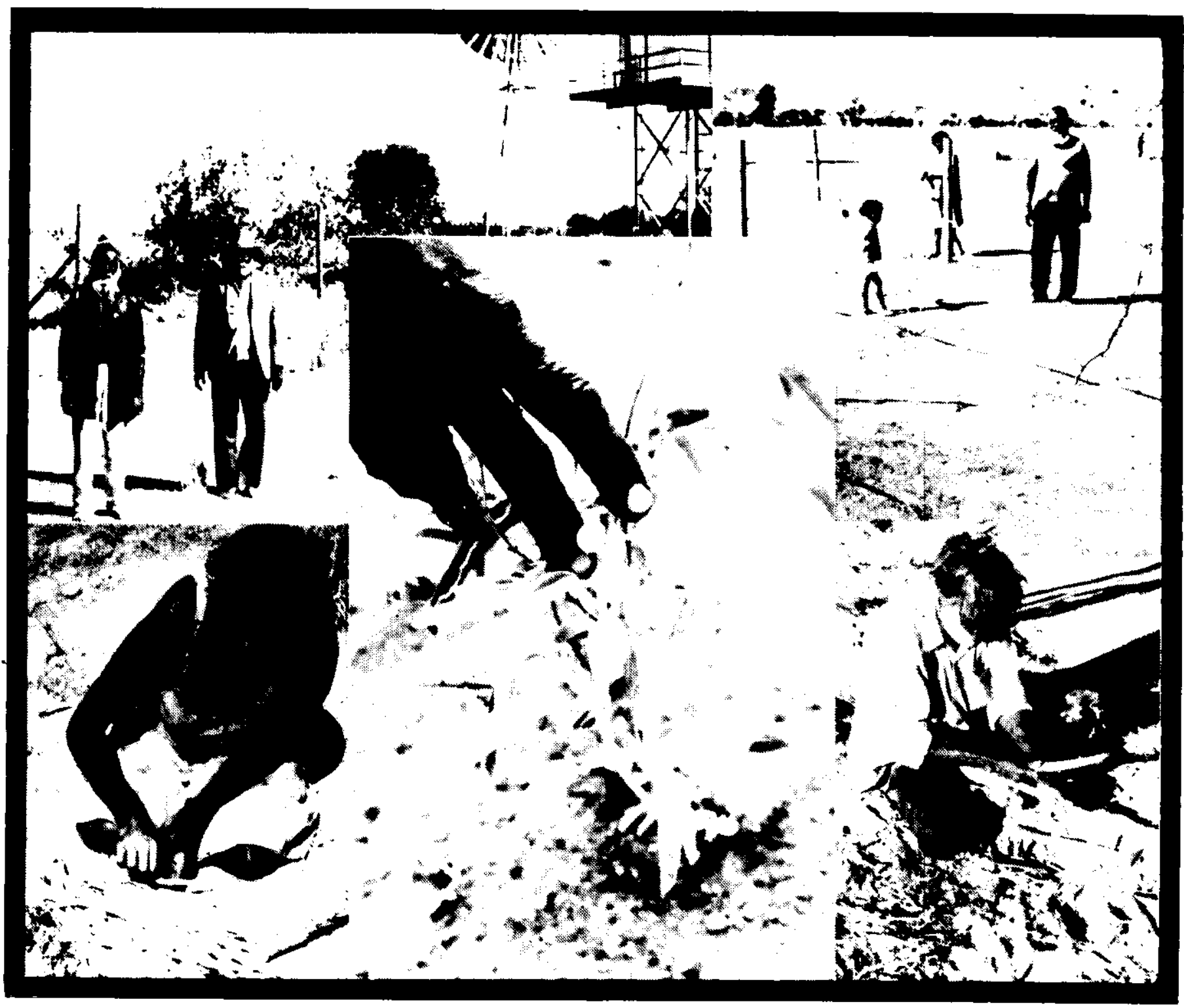

NARU

HD1039

. $\mathrm{C} 46$

. $\mathrm{C} 36$
Australian National University

North Australia Research Urit

Monograph

Darwin 1985 
$\checkmark$

$\checkmark$ 


\section{Land Use and Resources in Desert Homelands}

by

\section{Scott Cane and Owen Stanley}

Australian National University

North Australia Research Unit

Monograph

Darwin 1985 
First published in Australia 1985

Printed in Australia by the Australian National University

(C) Australian National University North Australia Research Unit

This book is copyright. Apart from any fair dealing for the purpose of private study, research, criticism or review, as permitted under the Copyright Act, no part may be reproduced by any process without written permission. Inquiries should be directed to the publisher, North Australian Research Unit, Casuarina NT 5792, Australia

National Library of Australia

Cataloguing-in-publication entry

Cane, Scott.

Land use and resources in desert homelands.

Bibliography.

ISBN 0867847662 .

[1]. Aborigines, Australian - Reserves - Australia, Central. 2. Rural development - Australia, Centra1. 3. Land use, Rural - Australia, Central. [4]. Aborigines, Australian - Australia, Central - Economic conditions. I. Stanley, Owen. II. Australian National University. North Australia Research Unit, III. Title. (Series: Monograph (Australian National Univeristy. North Australia Research Unit)).

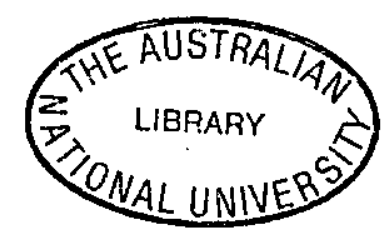




\section{Table of Contents}

List of Tables

List of Figures

List of Plates

vii

Acknowledgements

Chapters

1. Introduction

2. The Economic Environment

3. Pintupi Homelands

4. Luritja Homelands

5. Walpiri Homelands

6. Pitjantjatjara/Ngaanyatjara Homelands

7. Pitjantjatjara/Yangkuntjatjara Homelands

8. The Overview

9. Concluding Recommendations

Appendices

1. Names and Linguistic Area of Camps Visited

2. Check List of Data Recorded in Project

3. Bush Plants Referred to by Common Names in Text

4. Addresses of People and Organisations Referred to 
2.1 Population numbers and growth rates for the Alice Springs Statistical subdivision and percentage in employment

2.2 Employment by industry in Central Australia, Persons, 1981 Census

2.3 Data concerning the marketing of Aboriginal artefacts through 'the Company', 1979-80

2.4 Aboriginal employment in certain comanities, Persons, 1981 Census

2.5 Department of Commity Development expenditure on outstation development, 1980-81 to 1984-85 organisations, 1982-83

2.7 Government grants and subsidies received by outstation organisations, 1979-80 to 1983-84

3.1 Profiles of the outstations visited in the Pintupi Homelands

3.2 Land summary of Pintupi Bomelands

4.1 Camps occupied and vacated in Luritja Homelands

4.2 Profiles of outstations visited in Luritja Homelands

4.3 History of population and land use at outstations visited in Luritja Homelands

4.4 Land summary of Luritja Homelands

5.1 Profiles of outstations visited in the Walpiri Home lands 
6.1 Profiles of outstations visited in Pitjantjatjara/ Nganyatjara Homelands

6.2 Land summary of Docker River Region

7.1 Profiles of outstations in Pitjantjatjara/ Yangkuntjatjara Homelands

7.2 Land summary of Ernabella Region

8.1 Comparative number of people recorded at

8.2 Number of camps in use in the Homelands visited

8.3 Age structure of people recorded living at camps visited compared to age structure at Yuendumu

8.4 Level of facilities at camps recorded

8.5 Number of houses, radios and toyotas at camps recorded

8.6 Water facilities at all camps visited

8.7 Number of camps with excessive levels of nitrate, fluoride and other contaminants

8.8 Level of services at camps recorded

8.9 Relative importance of bush foods at camps recorded

8.10 Major contemporary bush foods and their cultivation potential 


\section{List of Figures}

1.1 Homeland regions visited 3

2.1 Alice Springs statistical subdivision 7

3.1 Locations of Pintupi camps visited 36

3.2 Water quality at camps west in Pintupi Homelands 40

3.3 Eire patterns in the Pintupi Homelands 1981, $1983 \quad 47$

4.1 Location map of Luritja outstations visited 51

4.2 Water quality of camps in Luritja Homelands 65

4.3 Fire patterns in the Luritja Homelands, 1979, 198372

5.1 Location map for Walpiri outstations 85

5.2 Water quality of camps in Walpiri Homelands 91

5.3 Mean rainfall and temperature profiles for Yuendumu 96

5.4 Fire patterns in the northern Walpiri Homelands 99

6.1 Location map of outstations near Docker River 111

6.2 Water quality of camps near Docker River 116

6.3 Mean rainfall and temperature profiles at Giles 119

6.4 Fire patterns in Docker River region 123

$7.1 \quad$ Location map of outstations near Ernabella 133

7.2 Water quality of camps near Ernabella 141

7.3 Mean temperature and rainfall for Ernabella 145

7.4 Fire patterns in the Ernabella region 147

8.1 Approximate distribution of camps in the Western Desert 161

8.2 Distances of camps from communities 179 


\section{List of Plates}

\begin{tabular}{|c|c|}
\hline 3.1 & Aboriginal outstation - Muyinnga \\
\hline 3.2 & Aboriginal outstation - Muntarti \\
\hline 4.1 & First stage or 'Colourbond' houses at Alkipi \\
\hline 4.2 & Part of the camp at New Bore \\
\hline 4.3 & Hand pump at New Bore \\
\hline 4.4 & Shower facilities at Mt Liebig \\
\hline 4.5 & Collecting bush tomatoes at Ilpili \\
\hline 4.6 & Large area cleared for garden at Mt Liebig \\
\hline 4.7 & Small garden attempted at Ili Ili \\
\hline 4.8 & $\begin{array}{l}\text { Burning holes through red beans for decoration } \\
\text { at New Bore }\end{array}$ \\
\hline 5.1 & Camp at Wayililinypa \\
\hline 5.2 & Camp at Yumurrpa \\
\hline 5.3 & Cleared area for orchard at Yaribiilangu \\
\hline 5.4 & Row of bean trees planted at Emu Bore \\
\hline 5.5 & $\begin{array}{l}\text { Planted trees, Chinese lantern and attempted lawn } \\
\text { growing at Wayililinypa }\end{array}$ \\
\hline 5.6 & Chook pen at Yumurrpa \\
\hline 6.1 & Kutjuntari waterhole \\
\hline 6.2 & Open hexagonal house at Kunapula \\
\hline 6.3 & Petermann Ranges near Docker River \\
\hline 6.4 & Trellised grapes growing in the garden at Puta Puta \\
\hline 6.5 & Pecked vegetable at Puta Puta \\
\hline 6.6 & Hiding watermelons from birds at Puntitjarta \\
\hline 6.7 & Large pumpkin patch at Puntitjarta \\
\hline 6.8 & Dead garden at Warrapura \\
\hline
\end{tabular}




$\begin{array}{lll}6.9 & \begin{array}{l}\text { Destruction of ground cover around areas of rabbit } \\ \text { infestation }\end{array} & 130 \\ 7.1 & \text { Fibro house at Katjikatjitjara } & 130 \\ 7.2 & \text { Visitor accommodation built at David well } & 139 \\ 7.3 & \text { Temporary shed constructed at New Well } & 139 \\ 7.4 & \text { Result of an afternoon hunt near Araluen Bore } & 149 \\ 7.5 & \text { Present garden at Itjinpiri } & 149 \\ 7.6 & \text { Garden at Tjatja } & 151 \\ 7.7 & \text { Small fruit trees (peaches, mulberry) in garden at } & 151 \\ 7.8 & \text { Katjikatjitjara } & 153 \\ 8.1 & \text { Red gums planted around house at Katjikatjitjara } \\ 8.2 & \text { Fire lit in spinifex as people walk across plains } \\ 8.3 & \text { 'Rings' of spinifex ready for burning } \\ 8.4 & \text { Pintupi people with a collection of bush potatoes, } & 183 \\ 8.5 & \text { native yams and bush tomatoes } & 190 \\ 8.6 & \text { Cyperus bulbs roasting in hot sand and coals } \\ 8.7 & \text { Witchetty grubs collected from a coolibah tree } & 190 \\ 8.8 & \text { Pintupi man preparing spears for trade } & 192 \\ & \text { Kangaroo being baked in earth oven }\end{array}$




\section{Acknowledgements}

Special thanks are extended to Elizabeth Cane who assisted with the field research, typed and proofed the initial drafts of the report.

We would also like to thank the Aboriginal communities of Kintore, Papunya, Yuendumu, Docker River and Ernabella for their assistance and hospitality during field work (see introduction also). Particular assistance at these communities was given by Pat Kemp, Jill and Arpad Kolatas and Mike Bowden.

In Alice Springs, advice and assistance was given by Yami Lester, J. Liddle, Stuart Philpott, Ray McGuiness, Rob Cruikshank (deceased), Peter Latz and the officers of the Department of Aboriginal Affairs. Dr Peter Loveday, Field Director of the North Australia Research Unit (NARU), Dr Pat Werner from CSIRO Darwin and Michigan State University, and Dr Elspeth Young from the Australian Defence Forces Academy Duntroon, read the draft of this monograph and made valuable comments.

In the final stage of the report invaluable assistance was provided by Betsy-Jane Osborne who drew the figures in chapters 3 to 8. Leona Jorgenson typed the tables accompanying the land summary figures. The typing pool in the Research School of Pacific Studies typed the remaining tables in the text. Dragi Marcovic from the Department of Prehistory (RSPacS), ANU, prepared the photographs. The Department of Prehistory (RSPacS) provided production facilities during the writing of the report. Robyn Darben, Janet Sincock and Raelene Cummings (NARU) are thanked for their patient typing of later versions of this monograph. The NARU Librarian, Colleen Pyne, gave valuable assistance with the references.

Finally, we are most grateful to the Department of Aboriginal Affairs for funding this project. 
Chapter 1

\section{Introduction}

Terms of Reference and Method of Study

On 26th January 1984, the Department of Aboriginal Affairs accepted a tender from the North Australia Research Unit (NARU) of the Australian National University to undertake a study of land use practices and related matters in outstations in central Australia. The terms of reference required that the Unit report to the Minister of Aboriginal Affairs on the following matters, as aids to policy making:-

1. The locations of outstations and their extent amongst the various language groups.

2. The demographic characteristics of outstations.

3. The histories of outstations and of their resources.

4. The histories and current traditional and European land management practices.

5. The availability and quality of land, water, animal and vegetable resources.

Further, the study was to comment on the economic and social dynamics of outstations and to make recommendations on policy matters.

To undertake this task, NARU employed two researchers, Dr Scott Cane, a prehistorian with extensive field experience at Balgo in western Australia, and Dr Owen Stanley, an economist who has been conducting studies of the economics of Aboriginal communities since 1974. Scott Cane and family undertook the fieldwork and Owen Stanley concentrated on policy related matters. To assist the study with advice, an advisory committee was formed in Alice Springs, consisting of J. Liddle from the Central Australian Aboriginal Congress and $Y$. Lester from the Institute of Aboriginal Development. Thanks are extended to these gentlemen.

Fieldwork commenced on 24 th April 1984 and continued until 17 th August 1984: Processing and writing the material took until April 1985. It was first thought that it would be necessary to select a small number of outstations, study them intensively, and collect less detailed information on a large number of others. As the study developed however, it became clear that it would be possible to make a comprehensive study of a large number of outstations and this procedure was followed.

The intitial step was to contact as many outstation organisations in the study area as possible, by letter and in person, to explain the nature of the project and to seek their permission to visit. Those contacted were at Docker River, Ernabella, Fregon, Hermannsburg, Kintore, Papunya, Utopia, Warburton, Wingellina and Yuendumu. Permission was recieved first from Yuendumu, then from Docker River, Papunya, Kintore and Ernabella and 
these regions were visited in that order. Permission was later received from Fregon, Warburton and Utopia, but insufficient time prevented visits to those regions. Consequently, they were excluded from the study. Figure 1.1 shows the areas studied.

Most of the field work was conducted by Scott Cane, his wife Elizabeth and their three daughters. Owen stanley accompanied them on the field trip to the outstations near Papunya. Fieldtrips lasted between ten days and two weeks and were separated by five to seven days in Alice Springs. This time was used to organize successive trips, work on fieldnotes and tapes, to consult with the advisory committee and to collect data available in Alice Springs.

During field trips we worked closely with Aboriginal people and some Europeans and we wish to thank them. At Yuendumu we visited 13 camps and were aided by Sandy Tjurra, Lumi Tjakamarra, Paddy Tjapaltjeri and Peter Bartlett. At Docker River we also visited 13 camps and worked with Arpad Kolatas, Charlie Walkabout, Bill Munanti, Heizicle Tjinguna, Sam Protty, Andrew Tjakamarra, Joseph Donald, Anatjari No. 2, Ivan Butler, Henry Giles, Walingurra, Maggie Porter and several other women. At Papunya we visited 12 camps with Menzies Tjampitjinpa, Ray Ingkamala, Barney Tjakamarra, Andy Tjungarayi, Allister Burns, Peter Tjungarayi and Whiskey Tjapaltjeri. At Kintore we visited six camps with Billy Nolan and Benny Tjapaltjeri and at Ernabella we went to nine camps with Gordan Ingkatji, Harry Brumby, Alex Minadjugu, Tjimi (from Tjatja) and Ruby Archee.

In the course of the field work we visited 53 outstations, six communities and travelled $18,000 \mathrm{kms}$. The outstations visited are listed alphabetically in Appendix 1. Data were collected for each outstation with the aid of the 26 point check list shown in Appendix 2 . In addition, information was recorded with the aid of 360 photographs, 900 minutes of tape, four notebooks and 197 foolscap pages of diaries.

The structure of the report is as follows. Chapter 2 describes the general economic scene in which outstations exist, and the avenues available to them for obtaining resources not obtained from. the bush. Chapters 3 to 7 present descriptions of the homeland regions visited. Each of these chapters deals with the same set of issues: the background and motivation for the homeland movement, population structure and mobility, facilities and services, the nature of land use, and discussion of the findings. Chapter 8 presents comparative data and discusses some general issues. Chapter 9 provides a list of comments and recommendations. There is considerable overlap and some repetition in the presentation of data and discussion. This has been done deliberately to aid readers who choose to read particular sections of the report of special interest to them, rather than read the whole report. Chapter 1 was written by cane and stanley. Stanley wrote Chapters 2 and 9 and Cane wrote Chapters 3 to 8 . Each writer, however, contributed to the other's chapters and both writers are jointly responsible for the comments made in the report. 
Figure 1.1

\section{Homeland regions visited}

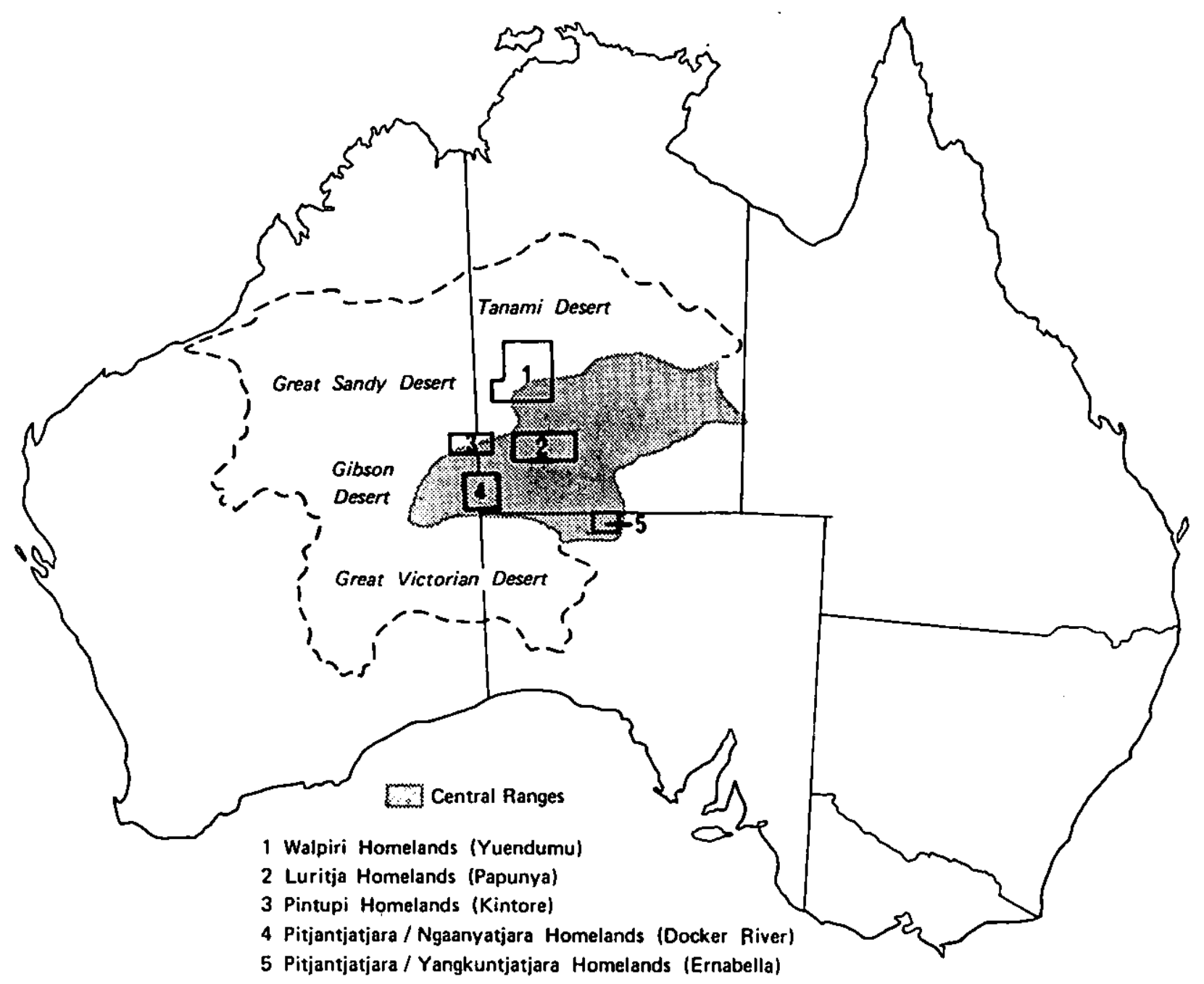




\section{Terminology}

There are a number of terms used in the report which require explanation.

The first of these is the term 'outstation'. The particular merits of this term have been reviewed elsewhere (Nathan and Japanangka 1983, Gerritsen 1982) and it has become popular to use what Europeans perceive as a more acceptable term - 'homelands centre' (see for instance Brokensha and McQuigan, 1977). However the terms 'outstation' and 'camp' have been used in this report because these are the terms which Aborigines themselves use. Aborigines do use the term 'homeland' to refer to traditional areas of land where their camps are located and consequently we use the term in the same context here - e.g. Walpiri Homeland, desert homelands or homeland movement. The Aboriginal term for outstations in the Western Desert is ngurra tjugutjugu - or little camp (compared to ngurra pulka - or big camp or community).

Other terms used in this report in reference to camp stability, facilities, services and land use also require definition. These are defined below and the implications of these definitions are discussed in Chapter 8.

\section{Camp Stability}

Stable: Camp in regular use at the time of our visit.

Unoccupied: Permanent group of people living regularly at the camp but absent at the time of our visit.

Abandoned: No evidence that the camp has been used consistently for at least three months.

\section{Facilities}

Standard: A camp with one ABTA toyota, underground water and hand pump, 2 way radio, one 'first stage house' per family or five people.

Substandard: A camp at which any of these facilities are missing.

Superior: A camp with more than standard facilities.

\section{$\underline{\text { Services }}$}

Standard: Regular weekly visits by a health sister or within two hours access of health care. Within two hours access of store food and one hours access of schools.

Substandard: A camp not receiving standard services.

Superior: A camp with more than standard servicing. 
Traditional land use

Minor: Minor burning of landscape; bush foods contributing about 158 of food eaten at outstations, use of wood for building, firewood and artefact making.

Moderate: More than minor evidence of Aboriginal burning; bush food contributing between 20 and 508 of food eaten at outstation; use of wood for building, firewood and artefact making.

Major: Extensive Aboriginal burning; bush foods contribute 50 per cent or more of food eaten; wood used extensively for building, firewood and the manufacture of artefacts.

\section{European Land Use}

Minor: Incipient gardens and/or little animal husbandry.

Moderate: Moderate sized gardens $(25 \mathrm{~m} \times 25 \mathrm{~m})$, camp improvements and/or more substantial involvement in animal husbandry.

Major: Large garden (greater than $25 \mathrm{~m} \times 25 \mathrm{~m}$ ), extensive camp improvements and/or extensive involvement in animal husbandry. 


\section{Chapter 2}

\section{The Economic Environment}

The past, present and future of the outstation movement in central Australia are greatly affected by its general economic and political environment. Outstations are not islands of economic and political activity. Rather, they are integrated into the general economic and political scene. For example: developments and employment opportunities in the general region will affect the standards of living which people can achieve on outstations and away from them; the volume of many resources available to outstations is determined by policies made in Canberra and elsewhere; the rules and regulations which people must conform to in order to gain access to many resources are imposed by people from distant places and a distant culture. The need for brevity here means that only the most relevant parts of the economic environment will be discussed and that the discussions themselves will be far from exhaustive. We will concentrate on two things. The first is the economy of central Australia in so far as it affects Aboriginal people and especially those on outstations. The second is the volume, nature and conditions relating to resources being directed to outstations.

\section{Economy of Central Australia}

The first thing to note about 'central Australia' (meaning, broadly, the Alice Springs statistical sub-division, which is composed of the local government areas (LGAs) of Alice Springs, Petermann, Sandover-Balance and Tanami) is that it has experienced considerable economic and population growth in recent years. The average annual population growth rates for the various LGAs between the 1976 and 1981 census are shown in Table 2.1. Figure 2.1 shows the areas covered by these LGAs. The population growth rates are high by world standards. The Aboriginal population is known to have a high growth rate but much of these population increases have been due to immigration of Europeans, to gain jobs in industries such as tourism, tourism-dependent industries, community services and building. Agriculture has not been a significant source of employment growth.

Table 2.1

Population numbers and growth rates for Alice springs Statistical subdivision and percentage in employment (The percentage of population in employment is shown in brackets)

\begin{tabular}{|c|c|c|c|c|}
\hline $\begin{array}{l}\text { Local Government } \\
\text { Areas }\end{array}$ & $\begin{array}{l}\text { Aboriginal } \\
\text { Population }\end{array}$ & $\begin{array}{c}\text { Non-Aboriginal } \\
\text { Population }\end{array}$ & Total & $\begin{array}{l}\text { Average annual } \\
\text { growth rates of } \\
\text { totals since } 1976 \\
\text { census }\end{array}$ \\
\hline
\end{tabular}

Alice Springs
Petermann
Sandover-Balance
Tanami

$2,974(23.0)$
$554(17.3)$
$1,661(16.9)$
$3,395(11.5)$
$15,421(51.6)$

$969(55.2)$
$602(65.3)$
$663(55.8)$

18,395

1,523

5.39

2,263

3.30

4.32

4,058

2.83

$8,584(16.9) \quad 17,655(52.4) \quad 26,239 \quad 4.75$

Source: Derived from ABS, 1982, Census Microfiche 
Figure 2.1

Alice Springs statistical subdivision

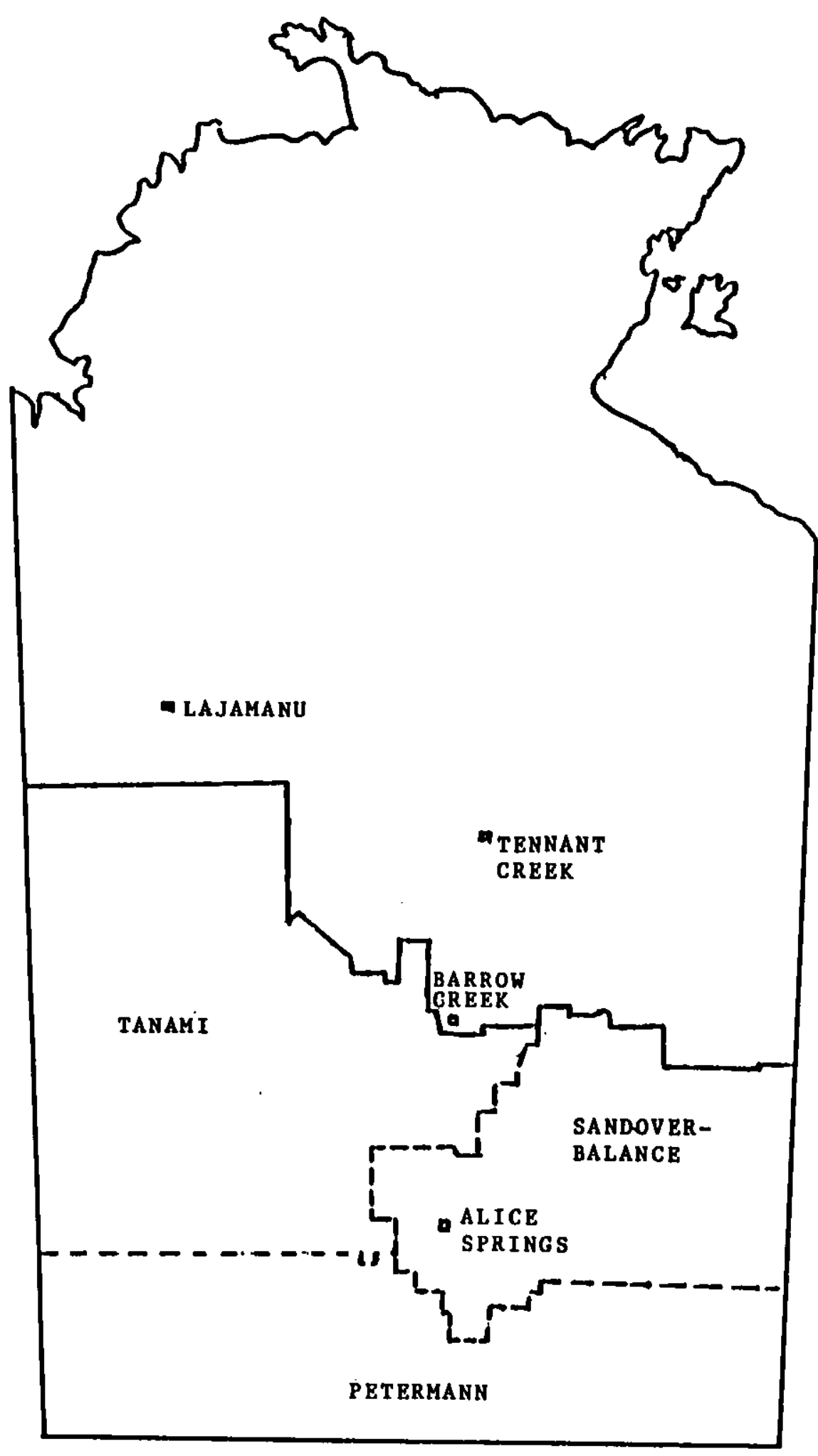




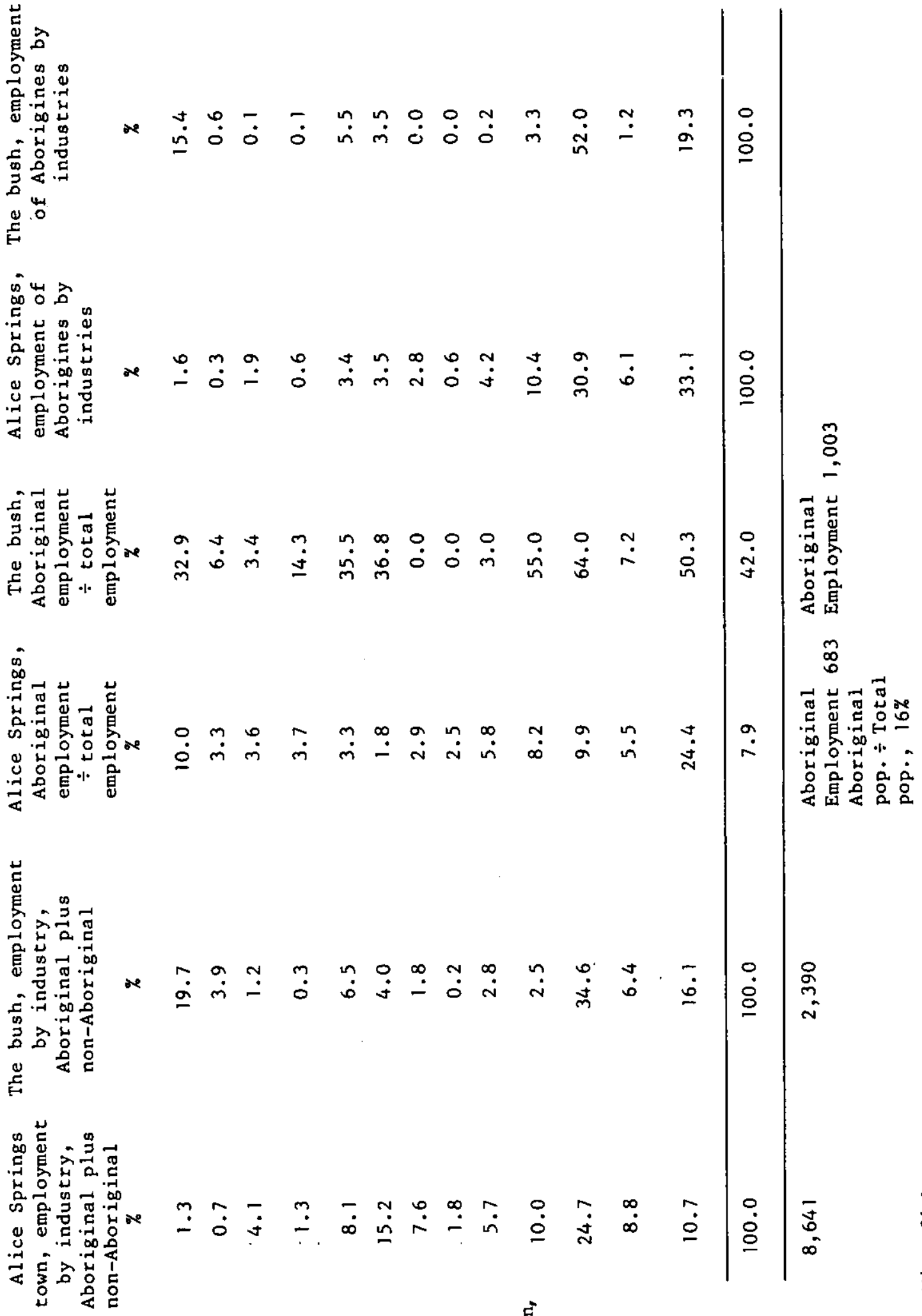

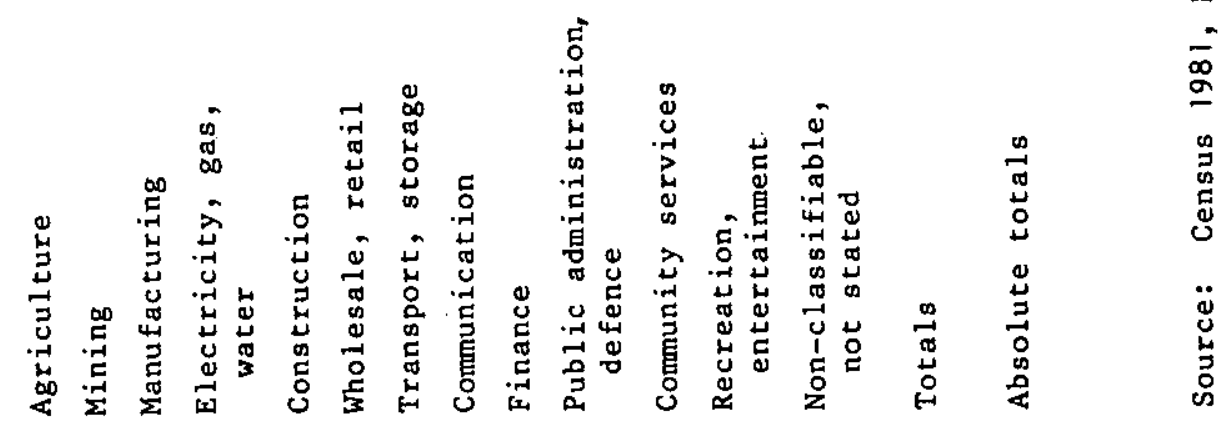


Table 2.2 shows data concerning employment structures in Alice Springs and 'the bush'. The 'bush' is the area composed of the Alice springs statistical sub-division, excluding Alice Springs itself, plus the South Australian communities of Ernabella, Fregon, Everard Park and Amata. No details could be obtained from census sources on pipalyatjara because to do so with its small population would cause a breach of confidentiality. The reason for including the South Australian communities is that they are also dependent on Alice Springs for various services. As can be seen from the two left-hand columns, the various industries are of about equal importance in Alice Springs and the bush, excepting agriculture, for obvious reasons, public administration, manufacturing, wholesaling and retailing, and finance, which reflects the role of Alice Springs as a major service centre for the area. Employment in the bush is dominated by employment in community services, and many people in this area work for Aboriginal communities and organisations.

The next two columns show the proportion of jobs in various industries which are occupied by Aborigines. Aborigines account for 16 per cent of the Alice Springs population but only have 7.9 per cent of the jobs. The youth of the Aboriginal population and higher unemployment rates account for this difference. Aborigines only gain a significant proportion of jobs in agriculture, public administration and community services. It is very likely that these jobs are in Aboriginal organisations or for government departments dealing with Aborigines. In the bush, Aborigines hold 42 per cent of all jobs and are important employees in community services, public administration, wholesale and retailing, construction, agriculture and essential services. Most of these jobs are on Aboriginal communities.

The last two columns shows the dependence of Aboriginal employment on the various industries. It can be seen that, in both Alice springs and the bush, Aboriginal employment is very heavily dependent on the community services sector and, as mentioned earlier, these jobs overall involve servicing Aborigines and Aboriginal communities. It is our contention that the labour market in central Australia broadly conforms to the 'dual labour market model'. That is, there are two markets for labour, Aboriginal and European, with jobs in different areas and having different conditions of employment. The relationship between the labour markets is such that an increase in demand for labour in one market does not necessarily flow through to the other market. In particular, we believe that the stimulation of the central Australian economy through tourism or any similar industry will not automatically lead to a substantial increase in demand for Aboriginal labour. Indeed the physical remoteness of many Aborigines means that they form an enclave in the central Australian economy and the projected development of central Australia may have very little effect on the standard of living of Aborigines in the area.

We will now discuss the development prospects for particular industries and their consequences for the welfare of outstation people.

\section{Tourism}

The prospects for the development of the tourism industry are good, all over the Northern Territory, and especially around the centre. The NT Development Corporation and the NT Tourist Commission $(1984,12)$ together prepared a study recently which estimates that the demand for tourist rooms in Alice Springs will rise from 897 in 1983 to 1800 rooms in 1990. Further, it estimates that the visitor trips to Ayers Rock will rise from 88,000 in 1983 to 202,000 trips in 1988. Both of these estimates seem unduly 
optimistic, but we do agree with the general proposition that tourism in the area will grow rapidly in the future.

Tourism has many direct and indirect benefits in generating facilities, income and employment. It can lead to the establishment of towns and roads, it can result in compensation to Aboriginal owners of the resource (as in the case of Ayers Rock), it can lead to employment in the tourist facilities themselves, in construction, retailing and wholesaling, transportation, community services and government administration. Pearse (1985), estimates that 100 jobs in the Northern Territory are created for an increase of $\$ 1.7 \mathrm{million}$ in expenditure by tourists and in tourism support (including construction of accommodation and roads, maintenance of parks, promotion, etc). Most of this employment takes place in the area where the expenditure takes place.

The question is, of course, whether Aborigines, and especially those in outstations, are likely to gain some of those jobs. We believe that unless Aboriginal employment is required under some agreement or unless they are proximate to the development, few Aborigines will be employed.

Aborigines are likely to benefit most from tourism where the development takes place on Aboriginal land. In such cases, Aborigines could be employed in the running of the facility, provision of food, grading of roads, production of artefacts, staffing guided tours, selling petrol, etc. In many areas visited during our fieldwork there were places which would be of considerable tourist interest and these could be developed to take advantage of the growth in tourism in the rest of the centre. Such a development could provide royalties and considerable employment in the facilities for people in the communities and outstations, if managed properly. It would involve the invasion of Europeans, and many people have moved to outstations partly to avoid them, so that there is a clear tradeoff, which would have to be considered carefully by the people concerned.

Mining

Despite a recent downturn in exploration in the Northern. Territory, mining is likely to remain an important and expanding industry in the long term. As in the case of tourism, Aborigines are likely to benefit very little from mining which takes place outside their land.

The Central Land Council (CLC) Annual Report, 1981-82, records that in its area some 119 exploration licences had been applied for. Mining on Aboriginal land has two major benefits: monies received under the Aboriginal Land Rights (Northern Territory) Act, 1976, and employment. Money received from mining under the Act is administered by the land councils and in 1982-83, the CLC royalty trust account received money from the Petermann Gravel Pit, the Yuendumu Mining Company, and under the Palm Valley Agreement. Monies received from miners are divided between the land councils [for administration ( 40 per cent), the affected community ( 30 per cent)] and the Aboriginal Benefit Trust Account (ABTA) (30 per cent) which is distributed at the direction of the Minister of Aboriginal Affairs. People in outstations benefit from the existence of the CLC, receive money as affected communities, and receive grants from the ABTA. Clearly an increase in mining will increase resources available to outstations. There are substantial social costs associated with mining for the people, of course.

Even on Aboriginal land, mining provides few jobs for Aboriginal people (see, for example, Stanley 1982 and Cousins and Nieuwenhuysen 1984). 
There appear to be both demand and supply reasons for this: that is, mining companies sometimes show little interest in employing Aborigines and Aborigines sometimes show unwillingness to be involved with a mining company working on their land.

The unwillingness of many mining companies to employ local workers is not confined to cases where the locals are Aborigines. Many small modern mines prefer to employ highly professional workers, who are housed in temporary accommodation, work weeks without breaks and are flown by the company to a major southern city for leave and recreation. Where this technique is used the mine has very little impact on the local economy. In such cases the mine is said to form a 'enclave' in the economy and such operations are of concern to all regions where this type of mining takes place. Even with conventional mining, production techniques are very capital intensive and few jobs are created apart from during the construction stage. Greater employment of Aborigines can be achieved when mining takes place on Aboriginal land through mining agreements requiring the employment of Aborigines.

Grazing

Aborigines have been employed in the cattle industry in central Australia from its inception. Until equal pay was introduced in the pastoral industry in 1968, the industry employed Aborigines on a 'feudal' basis. The station supported the Aboriginal camp, in varying degrees, and the camp provided stockmen who received 'pocket money' for their efforts. Little training was given to these workers and few of them achieved head stockman or mechanic status and none was given training in management. Whether this system was a truly profitable arrangement for the stations is open to question. Many stations employed mainly or only European labour and logic dictates that if the feudal arrangement was superior, those stations would make greater profits and force the others to imitate their practices. Further, although the equal pay decision related only to workers who were members of the union, pastoralists introduced equal pay on their stations even though Aborigines were not members of the union. Stanley (1976) found in 1974 that pastoralists in the Alice springs area broadly complied with the award, even though none of the Aboriginal employees were members of the union.

The equal pay decision did, however, radically change the economic structure of the cattle industry. Pastoralists reduced their employment of labour from an average of 550 man weeks per year in $1968-69$ to about 300 man weeks per year between 1975-76 and 1977-78 (Phillpot 1985). Aboriginal labour was shed and the stations provided facilities only for the remaining employees and their immediate families. Many of the 'social welfare' functions which some station managers performed were taken over by government agencies and some stations attempted to drive Aborigines from the land.

There are still many Aborigines working on cattle stations, of course. Parthmennathan (Phillpot op. cit.) estimates that one-third of the employees on Northern Territory cattle properties (including Aboriginal properties) are Aborigines, employed mainly as station hands and stockmen. Only seven per cent are employed as tradesmen and none as managers. He estimates that 77 per cent of them are under 30 years of age. Further, he suggests that they have a lower turnover rate than European employees.

Nevertheless, the declining employment opportunities and need for living space in the early 1970 s were amongst the factors which resulted in 
the government purchasing properties for Aborigines. Many of the missions and government settlements on Aboriginal reserves had cattle activities, but wages on reserves increased dramatically during the 1970 s and many of these projects met with difficulties.

In 1982-83 there were 23 Aboriginal cattle enterprises in central Australia. The following is a list of their names (Phillpot 1985).

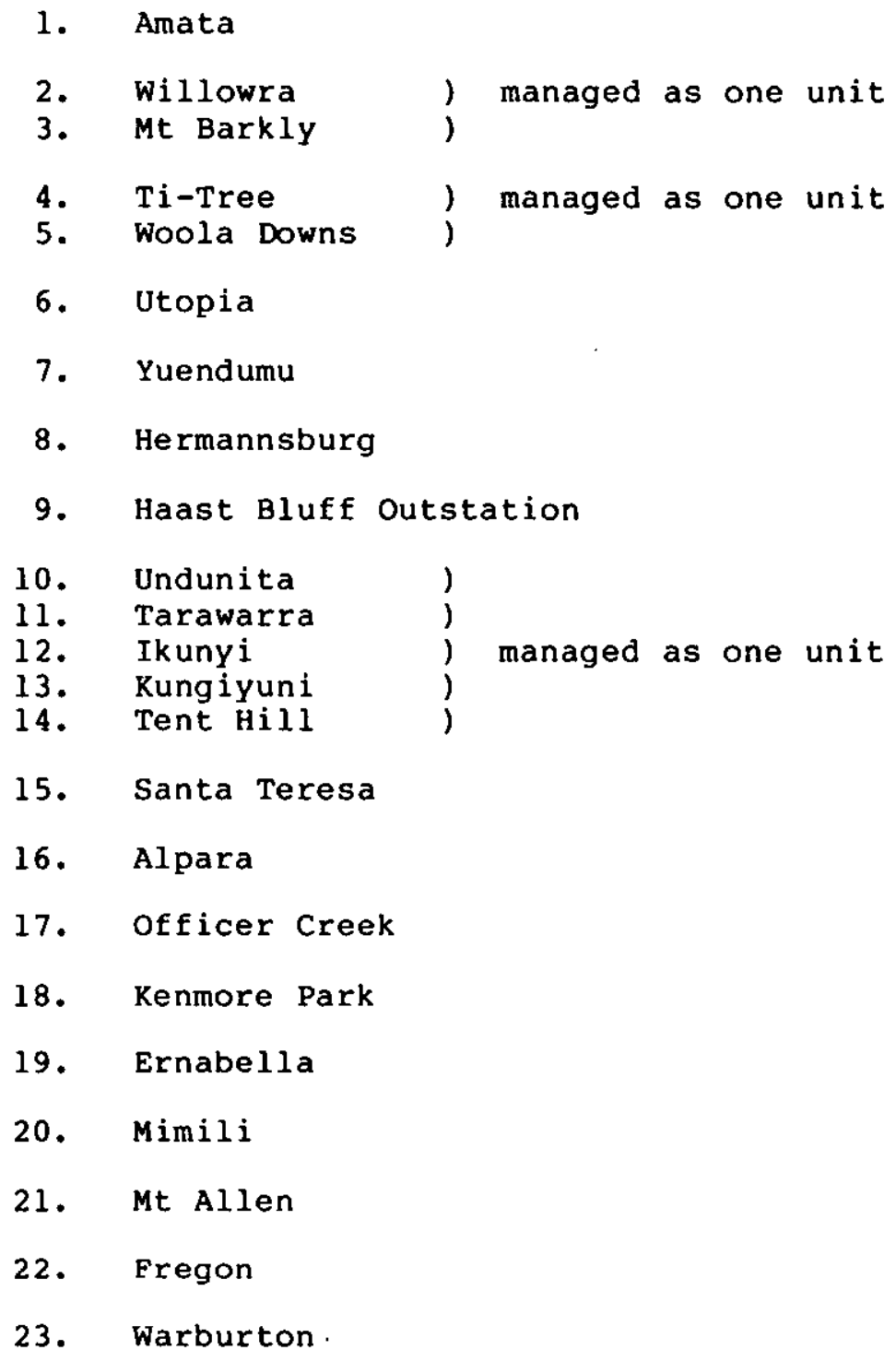

Overall, the benefits to Aboriginal groups of gaining stations or establishing cattle activities, on their land are, in varying degrees, the following:

1. A means of gaining land for living space, of allowing them to protect their sacred sites and to perform ceremonies in an unconstrained way. 
2. Providing employment of the type which is desired and does not conflict directly with the culture.

3. Providing training which can be used in gaining employment outside the community.

4. Providing a killer herd to supplement low cash and bush incomes.

5. Providing profits for the community.

6. Gaining independence from Europeans.

7. Gaining funding for the community, either for the cattle operations or for social overhead capital (houses, school, etc.) which would not be forthcoming without the group owning land.

Cattle operations, overall, have been moderately successful in providing these benefits with the exception of making profits. This poor profit performance is not surprising when it is considered that European cattle enterprises too have had great difficulties making profits.

In recent years, however, two important developments have taken place which complicate the operations of Aboriginal cattle enterprises. The first is the outstation movement itself. The economies of scale in cattle production require that large areas of land be worked as a single unit. The development of outstations on a pastoral property can lead to conflicts over many issues including who owns the cattle grazing on an outstation's land, royalties to be paid by the cattle company to the land owners of particular areas, outstations excluding cattle from areas which are good grazing country or vital watering points, and outstations excluding the company's cattle from large areas. Given low profits which cattle properties earn overall, these companies have little tolerance for increases in costs of production.

The second major problem is the bovine brucellosis and tuberculosis eradication campaign (BTEC). This is an important issue and deserves elaboration. Bovine brucellosis and bovine tuberculosis are contagious diseases found in cattle and buffalo for which there is no cure. Brucellosis causes abortions amongst cows and tuberculosis causes death and failure to thrive. Humans can be infected by both diseases. Generally speaking brucellosis is a problem in the south of the Northern Territry and tuberculosis is a problem in the north. These diseases have existed in Australia since at least the 1920 s and since that time state governments have instituted eradication policies, mainly for the purpose of protecting human health. Special attention was paid to tuberculosis in dairy herds prior to the pasteurisation of milk. By the 1960 s many foreign beef exporting countries had been successful with their 'eradication' programs and this put pressure on Australia to accelerate its programs. It was thought that national coordination was required because of the fear that Australian exports of beef and dairy products would be discriminated against on the grounds that trade within Australia would cause reinfection of areas previously rendered clean. Thus in 1970 an Australia-wide coordinated BTEC program came into being. The original aim was to achieve provisional freedom' by 1984. This would involve a prevalence of brucellosis of less than 0.2 per cent of the national herd and a prevalence of tuberculosis of less than 0.1 per cent. The program has been. largely successful in southern 
parts of Australia but there have been special problems in northern and central Australia which have led to the extension of the completion date to 1992. It is doubtful that even this date will be met.

The main problems in relation to the campaign in the Northern Territory are the following. Firstly, most stations have little fencing so that major fencing improvements have to be undertaken before economic numbers of BTEC clean cattle can be separated from feral animals. Secondly, BTEC clean herds must be kept behind fences and this means that management of such a herd is much more capital and labour intensive than under the open range grazing, causing cost increases that are resulting in financial difficulties for many stations and may result in some stations being abandoned. These abandoned stations and parts of pastoral leases not fenced will in time become major reservoirs of the diseases. The pastoralist receives some financial assistance including the following: cattle which are slaughtered under the program, including unmusterables, are compensated for at market prices after deducting transport costs; fencing and yard construction associated with BTEC programs receive a 100 per cent tax deduction in the first year; money from the sale of cattle as a result of destocking order does not attract tax until five years have elapsed; and pastoralists are aided in restructuring their debts. However, compensation in the form of tax deductions is of very little use to many pastoralists, including Aboriginal cattle companies, who do not generate taxable incomes. Meanwhile the program creates considerable financing problems for pastoralists.

The program affects Aboriginal interests in the following ways. First1y, financial difficulties experienced by some European pastoralists will result in more stations being offered for sale which can be purchased by Aboriginal interests. Secondly, the ADC underwrites and gives loans to Aboriginal cattle interests so that Aboriginal cattle enterprises can conform to BTEC requirements early. The purpose of this is to enable these enterprises to gain from being early suppliers of BTEC clean cattle to stations in the process of destocking. The profits from this process may not be great, however, if cattle producers in the southern and eastern states also actively seek this market. Thirdly, cattle management required under the BTEC program is much more rigid than is ideal for Aboriginal communities. The constant need to patrol and maintain fencing and the systematic turn-off operations required to meet interest payments on loans obtained for BTEC improvements, and to meet destocking plans, may impose undesirable burdens on the communities. Finally, the additional financial problems for an Aboriginal community associated with higher variable and capital costs of producing cattle and the lower revenues resulting from the stations carrying much smaller herds may lead communities to abandon cattle activities. The results of these forces is that Aboriginal cattle enterprises can no longer be run on a casual - and hence suitable - basis. Best European practices must be followed. Expert, contract musterers, probably from outside, must be used and so the advantages of running a pastoral property in terms of employment and training are lost. The greater financial planning required means an increased European involvement. Greater debts and small herds mean that the chances of making profits have become even more remote. Given these complications the options for Aboriginal cattle enterprises are: that either they are run like European stations, with few spinoffs to the local community, or that small BTB clean killer herds are maintained or that cattle operations be abandoned.

It is our opinion that the BTEC program is illconceived in relation to much of remote Australia. To some extent the program is based on naive 
beliefs about the politics associated with international trade in beef. Importers of beef such as the USA and Japan determine import quotas largely as the outcomes of conflicts between domestic producers and consumers, from the desire to open up markets for their exports, and as part of economicpolitical international relations. If it is convenient for such countries to reduce import quotas for Australian beef then no degree of BTB 'cleanness' in the Australian herd will deter them. Certainly the Industries Assistance Commission (1982) could not find evidence of a relationship between BTB in the Australian herd and access to export markets.

The costs of the program are immense. It is estimated that the cost to the Commonwealth and Northern Territory governments over the nine years to 1992 will be $\$ 105$ million although some authorities suspect that it will costs may be in the vicinity of $\$ 300$ million. To this must be added the costs incurred by private pastoralists. It seems highly likely that the government and private resources used in the BTEC program would be more efficiently employed in seeking new markets, particularly in Asia. Access to beef export markets is primarily a political, not an animal health problem and must be treated as such. Thus political manouvering including bargaining with potential buyers of Australian beef in terms of import quotas affecting their access to Australian markets, ought to be used. Meanwhile, the movement of cattle in Australia from areas where BTB remains a problem could be made subject to BTB testing and the very expensive program of restructuring cattle stations be abandoned. Such quarantine arrangements have been successful in the past. Limited disease control programs should be initiated in infected areas, of course. There is, however, a great cost difference between disease control and disease eradication, especially in the top end where 'clean musters' are considered to be impossible.

Many proponents of the scheme declare that one benefit of it is that it is 'bringing the Northern Territory cattle industry into the 20th century' by requiring fencing and careful management of the herd. Far from this being the case, it is taking the industry back into the 19 th century. The industry has high labour costs and high capital costs (caused partly by the fact that gross incomes fluctuate greatly while interest payments are constant). Low quality land, however, is cheap. Economic rationality, therefore, dictates a production technique which uses little labour and capital, but much land. The traditional open range techniques of the Northern Territory cattle industry are thus optimal under these conditions. The fencing and careful management of the herd which is being forced on the industry, therefore, is a misallocation of the nation's resources. Further, Aboriginal cattle enterprises often determine their own returns for labour. Insofar as wage rates reflect the supply and demand of labour for this type of work, this procedure is also optimal. Phillpot (op. cit.) found that Aboriginal cattle operations were more labour intensive (as they should have been) than European stations, in 1982: the average Aboriginal cattle enterprises in central Australia employed 323 man weeks per year for an average herd of 923 head, while the average European cattle enterprise in central Australia employed 450 man weeks per year for an average herd of 7500 head. It should be noted that most of the Aboriginal enterprises had partially or totally destocked under the BTEC program, while the European stations had not.

While it is suggested here that large cattle operations are likely to be of little value to outstation people, it will be suggested later that outstation people consider the possibility of maintaining small killer herds. Various schemes could exist. One possibility is that a group of 
outstations keep a small, BTB clean herd behind fences in some suitable area. Stock duties for a group of such herds could be undertaken by stockmen and apprentices. They would be employed by the relevant outstation organisation. Such herds would be relatively easy to manage in accordance with BTEC requirements. The arrangement would provide employment and training for a small number of people, and would supplement protein consumption while not leading to the destruction of vegetation which is useful for bush production. In some areas where the outstation population has become large, the constant burning of vegetation in the search of bush foods will lead to environmental degradation. This problem will become worse in some areas as the outstation movement continues to develop and the rate of natural increase remains high. Such killer herds would be usefulin reducing the pressure on vegetation and animal resources.

Similarly, small sheep herds could be kept by outstations for meat and wool. Sheep are sometimes harder to maintain because of attacks by dogs and flies. However, some of the more sedentary people may wish to keep them.

\section{Art and Craft $\underline{\text { Production }}$}

Art and craft production takes place in many outstations in central Australia. It was common, when visiting outstations, to find evidence of the making of spears, woomeras, necklaces, coolamons and sand paintings. It was not possible, in the scope of this study, to discover the contribution of this production to outstation peoples' incomes and only vague indications exist as to the importance of artefact production. Table 2.3 provides a range of data concerning the operations of Aboriginal Arts and Crafts Pty Ltd, known as 'the company', and established by DAA in 1971 to encourage the production and sale of Aboriginal art and craft.

Table 2.3

Data concerning the marketing of Aboriginal artefacts through 'the Company', 1979-80

Community

$\begin{array}{cc}\text { Community Sales } & \text { Markup by } \\ \text { to the Company } & \text { Company } \\ 1979-80 & 8 \\ \$ 1000 & \end{array}$

Hourly Earnings

Rates

8 /hour

\begin{tabular}{|c|c|c|c|}
\hline Hermannsburg & $<1$ & n.a. & n.a. \\
\hline Papunya & 10.2 & 28 & $\begin{array}{c}6 \\
\text { (sand painting) }\end{array}$ \\
\hline Warburton & 2.9 & 97 & n.a. \\
\hline Amata & 6.4 & 58 & (animal carvings) \\
\hline $\begin{array}{l}\text { Ernabella } \\
\text { Fregon } \\
\text { Mimili } \\
\text { Pipalyatjara }\end{array}$ & $\begin{array}{r}12.9 \\
3.8 \\
1.6 \\
3.1\end{array}$ & $\begin{array}{l}28 \\
29 \\
53 \\
78\end{array}$ & $\begin{array}{l}\text { n.a. } \\
\text { n.a. } \\
\text { n.a. } \\
\text { n.a. }\end{array}$ \\
\hline
\end{tabular}

Source: Arts Research, Training and Support Ltd, June 1981: exhibits III-6 and $\mathrm{V}-2$ 
This study provides us with some information which is useful. The company was the major outlet for these products produced in central Australia. The first column shows that, whatever the undoubted cultural benefits of these activities, they contributed only a small amount of income to the people living in central Australia. Further, these communities were not large suppliers to the company. Sales of Ernabella artefacts, for instance, accounted for only 4 per cent of national sales of the company (ARTS [1981] exhibit III-1). The figures on hourly earnings show that hourly wage rates in artefact production were quite good. Finally, the local tourist market was a large market, with Alice Springs alone accounting for 20 per cent of national sales of the company (ARTS [1981] exhibit VII-10).

These data together provide evidence for the proposition that a tourist development could provide a greatly increased income from artefact sales. A trek of the type described later would bring a potentially substantial market to the outstations. This would also lower transport, wholesaling and probably retailing costs of marketing artefacts and hence lower the required markup rates, thus increasing returns to the producers.

Regardless of whether this idea is taken up, the growth of tourism in central Australia provides a growing local market and local producers should enjoy a growing income from artefact production, providing the collection and marketing arrangements work effectively. However, regardless of how the total artefact market develops, it is not conceivable that income from these activities could grow to become a substantial proportion of total cash incomes coming into the communities and outstations. A growing demand for artefacts could, of course, provide substantial benefits to particular individuals, an important supplementary income for many, and provide substantial cultural benefits.

\section{Agriculture and Horticulture}

The growing of crops such as sorghum, maize, mung beans and soybean is confined to the Katherine and Darwin regions. Around Alice Springs, however, a range of fruit and vegetables is grown. The fruit include grapes, rockmelons and watermelons, and the vegetables include lettuces, cabbages, pumpkins, spring onions, parsley, silverbeet and zucchini.

In 1982-83, the most valuable crop in the Alice springs area was grapes with a total value of production of $\$ 31,600$ and, of the vegetables, only lettuces, cabbages and pumpkins had values of production in excess of $\$ 2,000$. The total value of fruit production was $\$ 59,700$ and of vegetable production was $\$ 34,900$ (Department of Primary Production, 1984: 49). These figures starkly reflect how insignificant horticulture is to the economy of central Australia. The industry with most promise seems to be the grape industry and Department of Primary Production announced recently a project to develop grape farms at Pine Hill, some $150 \mathrm{~km}$ north of Alice springs. The project will involve a $\$ 2$ million investment, with expected sales reaching $\$ 7$ million per annum, within the next 10 years. Employment is expected to reach at least 25 people permanently, with a seasonal workforce of 125 workers (NT News, 25 March 1985). One must be cautious with such expectations, of course.

Despite the possibility of expansion in employment in horticulture, and the possible employment of outstation people as seasonal and permanent workers, we believe that it is unlikely to provide much employment for Aborigines who normally live on outstations. 
There are two other ways in which outstation people could benefit from horticulture. Firstly, a certain amount of commercial European fruit and vegetable production could be undertaken on outstations and the products sold to local Aboriginal community stores or to the European community. Similarly, European fruit and vegetables could be grown for consumption by the grower. These types of schemes have been suggested and tried many times with little success to date. Thirdly, local bush resources could be harvested. One of the most promising products are plant seeds. These have been collected in the past and have yielded high per hour returns for the collector. Seeds of river red gums (Eucalyptus camaldulensis) and seeds of various acacia species have been collected. If such a program of seed collection was developed, seeds could be collected by the same agents as those who collect artefacts. Again, it is very likely that even if horticultural projects were to prove to be very successful, they would at best provide only a useful supplement to low cash incomes rather than a major source of income.

Table 2.4

Aboriginal employment in certain communities, Persons, $\underline{198} \frac{\text { census }}{1}$

\begin{tabular}{|c|c|c|}
\hline$\underset{8}{\text { Papunya }}$ & 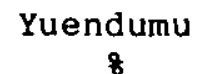 & Docker River \\
\hline
\end{tabular}

Agriculture

Mining

Manufacturing

Electricity, Gas, Water

Construction

Wholesale, Retail

Transport, storage

Communication

Finance

Public Administration

Community Services

Recreation, etc

Non-classifiable, not stated

Total

Absolute total employed

Aboriginal Population

4.8
-
-
-
3.2
3.2
-
-
-
1.6
76.2
1.6
4.8
100.0
63
561

Footnote: when obtaining percentges.

Source: Census 1981 Microfiche

\section{TMPU, Schools and Health}

Table 2.4 shows Aboriginal employment by industry for the communities in the regions where the outstations we studied are located. Data for Kintore were not available from the census 1981 microfiche. As can be seen, employment in community services dominates in these communities. This is the case in Aboriginal communities, generally (see Stanley, 1983, 1985a, 
1985b forthcoming). Employment on council duties (TMPU) composes the major category, followed by employment in the schools and clinics. Employment in these areas is likely to continue to grow as Aboriginal populations grow and as attempts are made to improve the quality of services in the communities. Only a few of these jobs will be available to outstation people, however. Some people who live in outstations near communities can commute to attend work, and some jobs will be decentralised to central outstations, however people living beyond commuting distance to work will have no opportunity to gain employment in these areas. Most outstation people fall into this category.

Summary

The discussion above suggests that the outstation movement is developing in a general economic context that involves a bleak outlook for jobs and cash incomes for people living on outstations, and to a lesser extent, in Aboriginal communities generally. To expect Aborigines to become economically independent of government aid is to expect them to achieve economic successes in areas where Europeans have been unable to generate significant economic activity over the last 200 years. This is clearly unrealistic. Aborigines suffer the same disadvantages in the form of labour and transport costs, poor soils and climate as Europeans living in similar areas; and Europeans cannot support large numbers of people who are dependent on the land in such areas. Substantial employment for Aborigines could be provided if local industries were supported with very large subsidies but we feel that this situation would not be maintained in the long run. Thus in the discussions to follow we will assume that most people on outstations will have few fulltime employment opportunities in the future, will have to rely mainly. on social security benefit incomes, will supplement their low cash incomes by occassional employment, the sale of artefacts and bush tucker production. Funding agencies will have to be relied on heavily to supply the social overhead capital expenditure (local government, schools and health facilities). As bleak a picture as this may seem to many Europeans, many Aborigines believe conditions in the outstations to be superior to the conditions they experienced in the Aboriginal communities and European towns.

\section{Volume, Nature and Conditions Relating to Resources Directed to outstations}

Outstation people are entitled to receive the same range of social welfare payments as other Australians. These include unemployment benefits, supporting mothers benefits, family allowances and aged, widowed, and sickness pensions. These constitute a large proportion of incomes and minor changes in their rates or the terms under which they are received can have major consequences for people on the outstations.

Outstation people also have access to resources because of their proximity to Aboriginal communities or European towns. Firstly, such large centres provide employment for people living in or near them. Secondly, the centre may provide access to more resources and many are of a superior quality to those available in the outstations. It is common, for instance, for a mobile store and a district nurse to visit outstations. There may even be a rudamentary school provided at a central outstation. However, shopping, health and education facilities are better at the community or town and outstation people will visit and stay at these centres partly to gain access to their superior resources. In some cases certain resources 
are only available at these centres. These include some shopping, health and education facilities as well as air transport and vehicle repair facilities. Thirdly, outstation organisations, their administration, their resources and their European employees are often based at these centres. Finally, the centres may be the places where political, social and ceremonial activities are arranged or take place and may provide a refuge for outstation people avoiding punishments or social disapproval.

Such relationships between the outstations and local communities mean that there is not a simple distinction between outstation and community resources and that improvements in facilities at the communities will often have benefits for outstation people. It is also true that since people usually living at the community visit and stay at outstations, an improvement in conditions at the outstations will benefit people usually resident at the community.

Various government departments provide resources for outstations, directly. Until the Northern Territory achieved self government in 1978, most matters concerning Aborigines in the NT were under the control of DAA. After self government the NT Department of Community Development (DCD) assumed responsibility for essential services, including water supply (drilling, testing, fitting) and roads for communities and outstations. DCD did not have an office in Alice Springs until 1981 so that until that year the department allocated resources largely on DAA's advice. The establishment of the office allowed DCD to operate independently of DAA and friction emerged between the two offices. One view is that unwillingness to share information has been a cause or a product of this friction and poor communications between the departments have led to mistakes being made in allocating resources to outstations. Recent attempts have been made to improve relations between the departments. DAA has been especially concerned about the lack of satisfactory water supplies in communities and outstations and hopes that cooperation between the departments and a costsharing arrangement will result in all communities and outstations gaining satisfactory water supplies by July 1985. The belief is that the good seasons of recent years cannot last and there is a sense of urgency about the water supply problem. It is clear that Aborigines, too, consider water supply to be of primary importance.

The cost of providing an adequate water supply for outstations are considerable, of course. As an illustration, the following costs have been derived from the appropriate DCD records: costs of drilling a bore $-\$ 5,000$ to $\$ 22,000$; costs of equipping a bore (including a tank and windmill) $\$ 50,000$ to $\$ 55,000$; costs of providing a hand pump $-\$ 2,000$ to $\$ 2,500$. The bores which are equipped with hand pumps require the user to pump the water to the surface when water is desired. Although this is a very cheap way of fitting a bore it is unpopular with Aborigines, especially the old people, who naturally prefer their bores to be equipped with a windmill and a water tank. Windmills and tanks are not only more expensive to install than hand pumps, they are also more expensive to maintain.

Table 2.5 shows the DCD expenditure on the outstations in the study area in the NT since 1980-81. The. Ernabella Outstations are not in the NT and so are not supported by the DCD. It is obvious from this table that expenditures on the outstations have fluctuated greatly between the outstation areas and over time for any particular group of outstations. These outstation systems are at different stages of development and the differences between the allocations are not surprising. In particular, the Kintore outstations are the most recent to develop and it is to be expected 
that DCD expenditure on them is greater than for the others. Further, Kintore itself, is developing as a major resource centre.

Table 2.5

Department of Community Development expenditure on outstation development, 1980-81 to 1984-85

$\begin{array}{lllll}1980-81 & 1981-82 & 1982-83 & 1983-84 & \begin{array}{l}\text { Proposed } \\ 1984-85\end{array}\end{array}$

\begin{tabular}{l} 
Kintore Outstations \\
\hline Bore Drilling \\
Water Equipment \\
Roads \\
Airstrip \\
Other
\end{tabular}

Totals

38,266
-
-
-

38,266

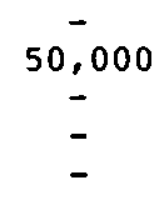

50,000

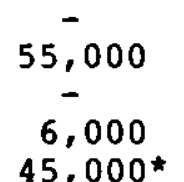

8,000

$\overline{0,000}$

$45,000^{\star} \quad 94,140$

106,000

142,140
80,000

430,000

60,000

$96,234^{*}$

666,234

* Including research expenditures

\section{Papunya Outstations Water Equipment}

Total

Yuendumu Outstations

$$
\begin{aligned}
& \text { Bore Drilling } \\
& \text { Water Equipment } \\
& \text { Rubbish Dump }
\end{aligned}
$$

Totals

Docker River Outstations Bore Drilling
Water Equipment

Totals

$\begin{array}{ccccr}- & - & - & - & 67,000 \\ \text { Nil } & \text { Nil } & \text { Nil } & \text { Nil } & 67,000 \\ & & & & \\ \text { n.a. } & - & 45,000 & 70,000 & \text { n.a. } \\ \text { n.a. } & - & 165,000 & 2,500 & \text { n.a. } \\ \text { n.a. } & - & - & 8,500 & \text { n.a. } \\ \text { n.a. } & \text { Nil } & 210,000 & 81,000 & \text { n.a. } \\ & & & & \\ \text { n.a. } & 45,000 & - & - & 180,000 \\ \text { n.a. } & 92,000 & - & - & 27,000 \\ \text { n.a. } & 137,000 & \text { Nil } & \text { Nil } & 207,000\end{array}$

Source: DCD Records

Until recently DAA retained responsibility for housing in outstations, however this role has been taken over by the Aboriginal Development Commission ( $A D C)$. It provides funds for all types of housing at communities and outstations. It is understood that people on outstations will not receive housing of the more substantial European style found in communities. Most outstation housing is in the form of small iron lock-up sheds with concrete floors. The costs of delivery and construction of these buildings vary greatly depending on the site's remoteness from Alice springs and other conditions. DAA files show, for instance, that costs have varied from $\$ 2,300$ to $\$ 4,000$ for each building. ADC also provides loans and grants for enterprises. Many other previous DAA responsibilities have been allocated to other departments and funding agencies so that DAA now has largely fillin functions. These include general surveillance, provision of transport equipment (usually vehicles), provision of communication equipment 
(radios), and the provision of finance for administration by community and outstation organisations.

Matters relating to health are the responsibility of the NT Department of Health. This department usually provides a nursing sister who visits outstations, substantial medical facilities at the nearby community, a resident or visiting physician for the community and arranges evaluation when necessary. The NT Department of Education provides education; however in general, outstations are not provided with their own schools and parents have to take their children to school, or more usually, children are left at the nearby community or at an outstation with a school during the school year. Aboriginal organisations are active in the areas of health and education, attempting to offset what they see as deficiencies in the services provided by the government.

Some resources from the above and other organisations are injected directly into outstations while others are allocated to local organisations who then administer them. The provision of water, health and education resources are usually administered directly by the departments concerned. The administration of many other resources is undertaken by the relevant outstation organisations or by the associated community organisations (grading of roads to the outstations, for instance, may be done by the community council).

The Aboriginals Benefit Trust Account (ABTA) is under the control of the Minister of Aboriginal Affairs and it, among other functions, provides funds for outstations. The ABTA was established in 1978 under the Aboriginal Land Rights (Northern Territory) Act 1976-82. It developed from the Aborigines Benefits Trust Fund (ABTF) which was established in 1952 to provide funds to assist Aborigines assimilate into the European community. The ABTF received, and the ABTA currently receives, monies from mining royalties. The ABTF provided funds for community development, housing, training and other such purposes. Most of these activities are now funded by other sources. The ABTA is a 'clearing house' for royalties received under the land rights legislation. Royalties paid by companies mining on Aboriginal land are paid into the account, from which 40 per cent is paid to land councils, 30 per cent is paid to the communities directly affected by the mining and 30 per cent is allocated by the Minister of Aboriginal Affairs. Some of the funds allocated by the minister have been used to make direct grants to outstation organisations. The ABTA guidelines for allocating funds include as priorities for funding, projects which aid independence and which involve the provision of basic facilities for outstations. Most of the funds directly allocated by the minister $(70$ per cent of grants) have been used for the purchase of vehicles (Altman 1983, 77, 81) and many of the vehicles found in outstations were funded in this way. As a general rule, the local organisation is required to provide 10 per cent of the purchase price of a vehicle and ABTA provides the remaining 90 per cent.

Ernabella (and Fregon) outstations have used Community Development Employment Projects (CDEP) funding to assist their development. This scheme is funded by the Department of Finance and administered by DAA. It is designed to assist self management and reduce the high rates of unemployment amongst Aboriginal groups. Under normal circumstances, unemployed Aborigines living in communities or on outstations receive unemployment benefits. However the community and/or outstations may apply to DAA to join the CDEP scheme. Government approval needs very broad acceptance amongst the Aboriginal group concerned. If the request is granted the 
rights of individuals to receive unemployment benefits are withdrawn and the local administering organisation receives a sum equal to the total of unemployment benefits which the group would have received plus up to 20 per cent of that sum for administration costs. The council then uses that sum to employ people and buy equipment. Although wage rates and the allocation of funds to wages or equipment purchases etc. are matters for the council, the DAA guidelines for the scheme state that an unemployed person living on an outstation would normally be expected to receive wages at about the same rate as his unemployment benefits entitlement.

The system as it has operated at Ernabella outstations has involved the establishment of a basic work program for each outstation. The outstation then receives a basic weekly allowance, or a greater sum if the program is major. Inspections are made regularly to observe progress and to seek explanations if progress is unusually slow.

The CDEP scheme, in principle, has many good features. Firstly, it can increase the degree of self management because the local community organisation has control over a greater proportion of resources coming into the community. This gives people greater oportunity to shape their society in the way they wish. Secondly, the increase in financial resources going to organisations can enable greater local production and greater provision of local facilities. Thirdly, the scheme can provide more jobs and under more flexible conditions than is usually possible. Fourthly, by providing jobs the scheme can provide training and work experience. Finally, the scheme can be used to subsidise enterprises which would not otherwise exist.

The scheme has had, of course, problems at various times and at various places where it was operated. The main problems are listed below. Overall, the scheme is considered to be operating successfully at Ernabella and it should not be inferred that the problems listed here are relevant or important at Ernabella. The problems are:

1. Once a community or system of outstations joins the scheme people who were once on unemployment benefits have no option but to work for the organisation, if they wish to continue to live in the area. This means that more power becomes concentrated in the hands of local administrators and individuals become more vulnerable to local politics. Further, this power may be concentrated in the hands of European council staff.

2. Workers on CDEP sometimes resent those on full wages if the two groups are doing similar jobs. Also, many people believe that a bonus should be paid to skilled workers (grader drivers, mechanics, etc.) on CDEP, who now usually receive only wages at their rate of unemployment benefits.

3. It is sometimes difficult to obtain a satisfactory work performance from CDEP workers. This is a result of low wages and because the economic environment results in there being relatively few 'meaningful' jobs. Consequently, the increased community production under the scheme may not be great and the work experience obtained from CDEP jobs may be counterproductive.

4. It is said that some councils have been unable to handle the financial and labour control problems associated with the scheme. 
5. Generally, the scheme has not led to the undertaking of a range of new projects. Rather, it has been used as a new way to finance projects of the type undertaken in the pre-CDEP period.

6. Finally, it is often said that the scheme is organised and administered by Europeans in the organisations so that it has not led to greater Aboriginal independence.

The scheme cannot be said to be an overwhelming success. However, despite its problems, it has so much potential that it ought to be encouraged as a way of $f$ inancing outstation and community development. The problems 1 isted above need to be worked on continuously. Most of them are not, of course, problems that are unique to the CDEP scheme and they apply in varying degrees to the usual operations of community councils and enterprises. Their solutions will not be easily forthcoming and will probably be unique to particular situations.

The Commonwealth Community Employment Program (CEP) is a new program undertaken by the Department of Employment and Industrial Relations, which is designed to reduce unemployment rates amongst the most disadvantaged employee groups, including Aborigines. The program finances projects which are undertaken by approved 'sponsor' organisations. These are usually State, Northern Territory, local government or community organisations. State and Territory government organisations are expected to contribute at least 30 per cent of the cost of the projects, while local government and community organisations, are expected to contribute at least 20 per cent. In the case of community organisations, the group most relevant to outstations, part or all of their contributions may be waived if the organisations can demonstrate their inability to make the contributions. Approval of a project will be granted only if it meets certain criteria, including the following: the sponsor organisation must be capable of managing the CEP grant and project; the project must employ previously unemployed people from a disadvantaged group; the project must be a discrete project, and labour intensive; the project, and employment, must last from three months to twelve months; and it must provide benefits to the community in addition to providing employment.

Funds from this scheme can be directed for the benefit of outstation people through a community company, the community council or the outstation organisation. Some money has been allocated by the Federal government to such organisations for the benefit of communities and outstations in the area of study. Projects approved in October 1984 were:

1. The Kungi Yuntu Cattle Company at the Haast Bluff community was awarded a grant of $\$ 306,639$ to employ fourteen men to undertake a major fencing program and for restocking under the BTEC program.

2. The Kaltukatjara Nguratjaku Council at Docker River was awarded a grant of $\$ 112,061$ to plant trees and to develop vegetable and ornamental gardens at the community and outstations: The grant will result in the employment of a botanist/horticulturalist and four gardening assistants for 52 weeks.

3. A grant of $\$ 119,233$ was awarded to employ nine Aboriginal women and one man for 52 weeks to liaise with communities and to establish a craft collective to retail artefacts at uluru National Park. It is hoped that about 500 craft workers in communities and outstations will benefit from the project. 
Outstations and remote communities may receive considerably more funding in the future under this and other programs as a result of a review of the program to be undertaken in the near future. The report of the review is expected to be completed in May 1985. The Minister for Employment and Industrial Relations, Mr Ralph Willis, in October 1984 declared:

The government's ultimate objective is to reduce the unemployment rate of more than 50 per cent amongst Aborigines to a level comparable with that of the general community (News Release, 223/84, 25 october, 1984).

Clearly, the achievement of this goal will require a very substantial increase in funding by the government.

\section{Outstation Organisations}

Table 2.6 provides data on the sources and distribution of funds obtained by the outstation organisations in the areas under study, for the year 1982-83. These organisations were very heavily dependent on DAA funds. Both the Papunya and Kintore organisation received a small amount of money from DCD. DCD expanded this allocation subsequently since it became clear that this 'outstation' is in fact developing into a community. On the expenditure side, it is clear that administration and outstation services absorb much of the resources available to the organisations. The figures for the Ernabella outstations are misleading because CDEP income and expenditures are not included in the table. Dwelling construction was an important cause of expenditure at Papunya, Yuendumu and Ernabella outstations and there were significant expenditures on garden supplies at Docker River and Ernabella.

The data presented in the table are, unfortunately, only a poor indication of how resources were used in outstations. There are several reasons for this. Firstly, each outstation organisation used its own method of accounting so that the way in which expenditures were grouped under headings varied between the organisations. For example, 'garden supplies' in one set of accounts may be included as 'other capital items' while in others those items are listed separately. Secondly, the accounts followed financial accounting rather than a cost accounting approach. This means that 'water supply' for instance, may include equipment for both domestic and garden use; or 'outstation services' may have included wages paid to an employee who worked in the areas of dwelling construction, vehicle repairs, water supply, radio repairs, etc and there is no way of allocating those wages to each of these categories. Thirdly, resources may have been supplied by the local community and the costs of those would have been recorded in community accounts. Finally, in some cases a resource was provided through an outstation organisation (water equipment, for instance) and in other cases it was provided directly by an external organisation. To some extent, outstation organisations are required to perform a 'fillin' role in providing resources. The inadequacy of such financial data as a reflection of resources available and used at outstations has required physical observations of these resources. Descriptions of them are provided in later chapters. 


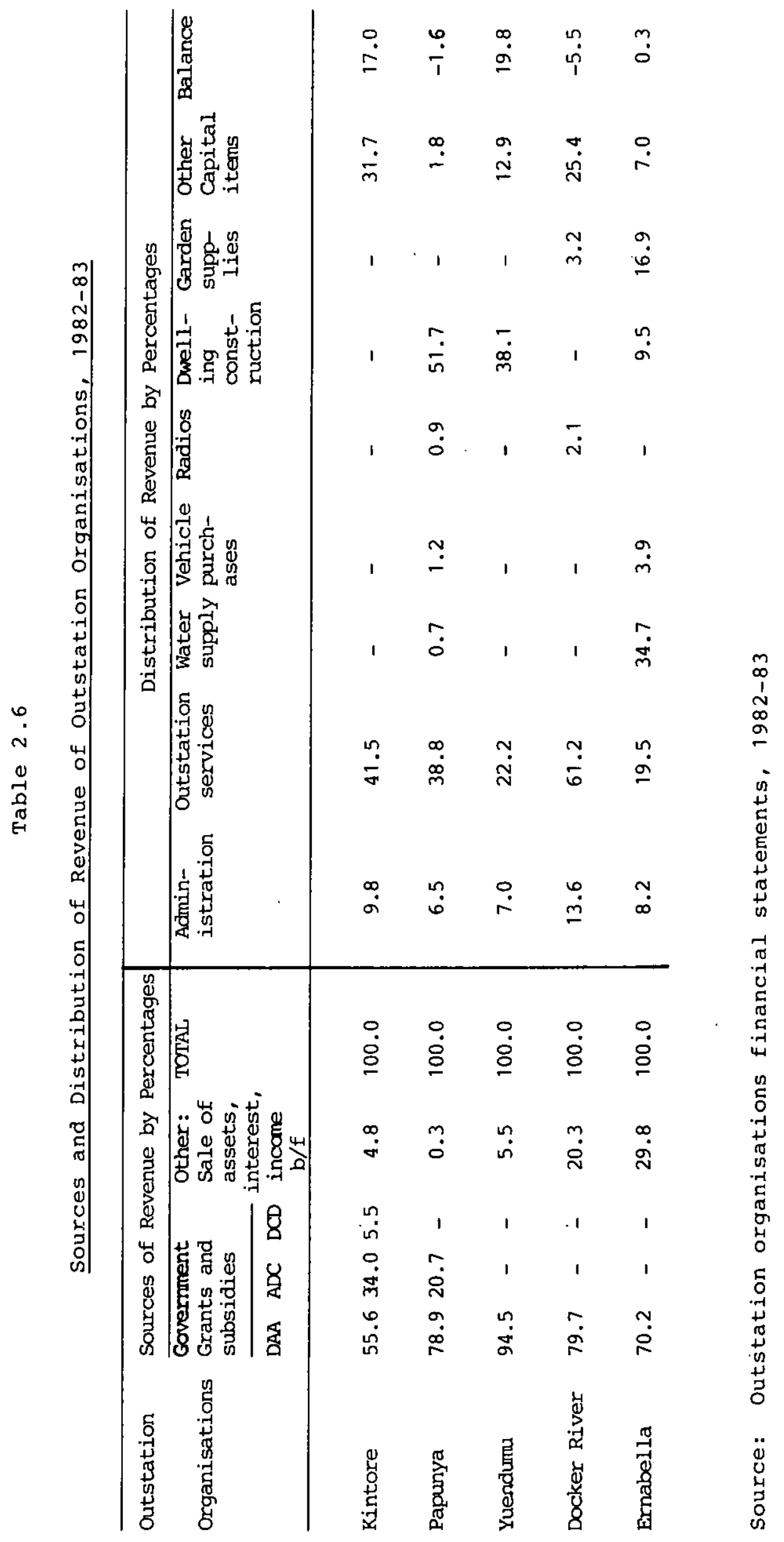


Table 2.7 shows data on government grants and subsidies (excluding CDEP grants) for outstation organisations from 1979-80 to 1983-84. Almost all of the funds granted to these organisations came from DAA, although some was obtained from ADC for housing and the Kintore organisation received a large allocation from DCD in 1982-83.

Table 2.7

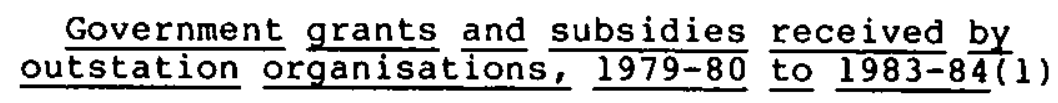

\$'000 in nominal values and (\$'000 in 1983-84 values using C.P.I.)

Year

Kintore

Papunya

Yuendumu

Docker River

Ernabella

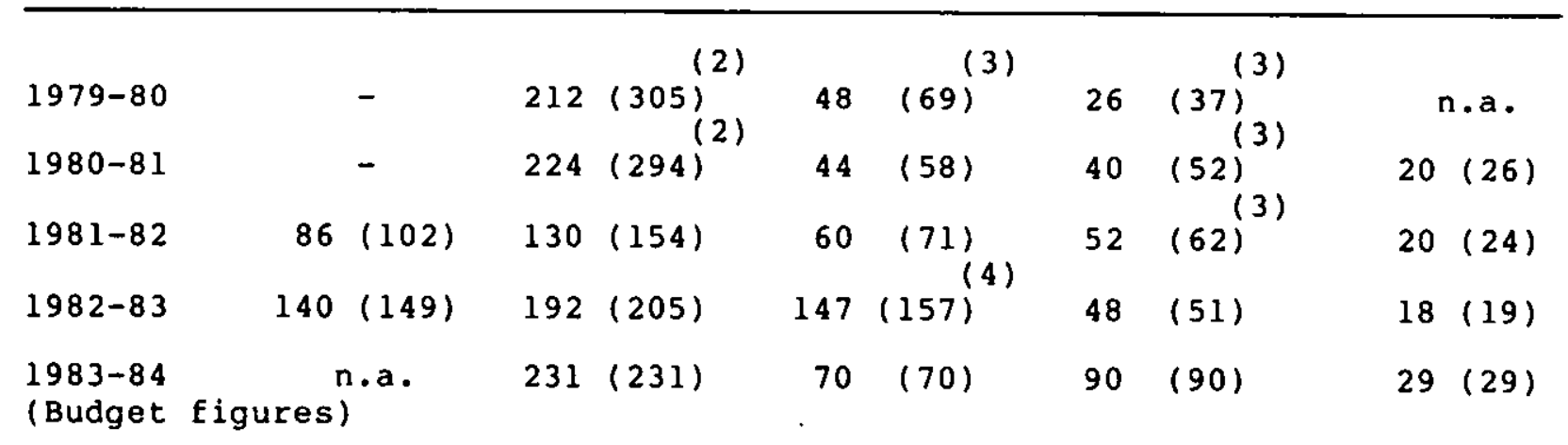

Footnotes: (1) Ernabella outstation development is partly financed by CDEP funds and organised by the Pukatja (Ernabella) Community Council. These funds are not included in the table since they would have been paid to the outstation people as unemployment benefits anyway. The outstation organisations were incorporated in the following years: Western Deserts Outstation Council (Kintore) in 1981, Central Deserts Outstation Council (Papunya) in 1978, Docker River outstation organisation in 1983 .

(2) In these years the 'Papunya outstations' included Kintore outstations.

(3) Figures obtained from Nathan and Japanangka, 1983.

(4) Includes a grant from the $A D C$ of $\$ 95,000$ for 'temporary housing', not spent in 1982-83.

Sources: Outstation organisations' annual financial statements unless otherwise indicated in footnote (3).

The real values of the grants and subsidies in 1983-84 values are shown in brackets, in the table. They reveal that the total amounts of these grants and subisides are not great, considering the number of people living at the outstations. The figures also show that there have been very considerable year-by-year variations in the level of support. Such 
fluctuations in support would make it difficult for any organisation to operate efficiențy and there is a strong argument for the development of a funding system which is more predictable. Certainly there is an argument for some type of two-year or three-year funding horizon.

There are two new concepts in DAA funding for outstation organisations which deserve comment:

\section{(1) Program Performance Budgeting}

DAA intends to move to this system in the near future. Under the system, community and outstation organisations will set, with DAA assistance if necessary, a goal for their funding. If the organisation's program is approved, funding will be provided and reports will be made to DAA regularly on progress toward the achievement of the goals. The goals will be stated in terms that are measurable physical aspects of projects. The department believes that system will be of benefit to the department and the organisation by improving efficiency and accountability.

\section{(2) Block Grants}

In an attempt to increase the degree of self management in outstation organisations, DAA has given them the option of adopting a block grant system. This allows the organisation to set its own goals, within limits, and to apply for funding for a whole expenditure program. In some cases, resources may be reallocated by the organisation from one use to another without DAA's approval. Permission will be required, however, where the funds are for items of capital, salaries and allowances. Most of the accountability conditions currently imposed on organisations will remain but it is hoped that some of these will be relaxed in the future. In its initial tentative form this system represents only a minor increase in local control. It may, however, develop substantially in the future.

\section{Conclusion}

The overall picture painted in this chapter of the general economic context in which outstations are developing is not an optimistic one. For most outstation people their sources of income are, and will remain, mainly DSS incomes, occasional employment (though some will enjoy continuous employment), and bush production (including the production of food and artefacts for sale). The availability of jobs, and conditions relating to them are determined very largely by administrative and political forces which are operating in the south and out of the control of outstation people.

Funds for social overhead capital and most enterprise projects cannot be expected to come from people whose incomes are so low. Thus funds are allocated directly to outstations or are channeled through local organisations. These organisations, however, have 1 ittle control over the ways in which these funds can be used and any major deviation from an approved budget requires the approval of the fund-granting authority. While attempts are made by authorities to gain the views of local Aborigines when deciding on a program, this process is a long way from allowing the people themselves to determine how resources ought to be allocated. Any use of funds in a way which deviates from the pattern most desired by a community represents a misallocation of resources. Clearly this type of misallocation is very significant in relation to outstations. 
There are three reasons which are particularly important in causing such misallocation:

1. The public service system of accountably is designed to detect accounting errors and fraud in relation to a project, rather than to answer the question, 'Should this project have been undertaken?'. This is not surprising since the system was developed to handle a situation where politicians decided whether a project should be undertaken and it was the public services' task to undertake the project as cheaply as possible. Thus, for instance, the public service is likely to spend much time finding or explaining a missing $\$ 2,000$ and little time on the fact that an outstation which cost $\$ 30,000$ to equip was unoccupied because it was built in the wrong place. Public service officers are concerned with such problems, of course, but the accountability system handles them in only a haphazard way.

2. When seeking Aboriginal opinions on how funds should be spent the authorities commonly ask the wrong question. An authority providing funds for housing for instance, may ask Aborigines a question to the effect, 'Would you like a larger house?'. When the answer is either, 'Yes' - possibly resulting in the respondent gaining a larger house - or 'No' - in which case the respondent receives nothing. Under these circumstances everyone would answer 'Yes' unless having a larger house actually made one worse off. Consequently, this question yields almost no information about Aborigines' tastes. The appropriate question is, 'If we gave you $\$ 25,000$, would you like to spend it on a larger house or on something else?' It is only when the respondent says he would like to spend it on a larger house, that the house ought to be provided. Otherwise the funds should be spent on the more preferred item. This problem is difficult to avoid because funds come from numerous bodies who can provide funding only for given purposes.

3. The returns from some expenditure are easy to calculate while the returns from others are not. The returns from enterprise activity are profits and employment and these are easy to observe. They tend to be low in the situation we are discussing here. Returns from expenditure on TMPU, health, education and housing are much more difficult to calculate. They are generally assumed to be high but they may be lower than those for enterprise activity. The result of the differences in ease with which returns can be calculated is that the rationality of a particular allocation of resources cannot be judged by people outside the community, and only with difficulty by those within it. In some situations, this factor has led to too much funding going to social overhead capital and too little funding going to enterprises.

4. Different funding agencies use different criteria to allocate funds to outstations. This leads to inconsistency (funds 'wasted' in one area and scarcity of funds in another) and none of the criteria may accord with the recipient's views.

The fundamental problem is that the underlying philosophy in relation to funding outstations (and Aboriginal groups generally) is dominated by the notion of 'donors rights': that is, the right of a donor to determine the size of the gift, who receives it, under what conditions and how it can be used. The 'donors' in this case are, of course, the general European 
Australian community and DAA in particular. There needs to be a change in philosophy to include the rights of Aborigines to receive funds at a certain level and to be able to do with them what they wish. Such a change in philosophy is needed in relation to all needy groups in the community, and not just Aborigines.

As already noted, there have been moves in the direction of giving Aborigines greater control over how resources are allocated within the outstations. The CDEP and block grants schemes are tentative moves in that direction. The ideal arrangement would involve total block funding which involved local control of all resources which currently come from DCD, Departments of Health and Education, DAA, ADC and other funding bodies. The local organisations would determine how all these resources are used. The budget should also be on a three-year or so basis, so that the organisations can plan their development. They should also be able to transfer expenditure to the future by investing surplus funds if they wish (the Gagudju Association has shown that a properly constituted Aboriginal organisation may have a very high investment rate - Stanley 1982).

The problems of achieving this ideal are obvious. Firstly, there are various governments and various government departments involved, with their own philosophy and positions to protect. Secondly, outstation organisations are often not effective political bodies at the moment. They will become more efective and representative as they are given more power, however, because more local people will become active in the organisations. Thirdly, the organisations will have to greatly develop their administrative abilities and this may result in the employment of more Europeans. It also may not, of course, because the need to account to government departments will diminish. Finally, there may be considerable problems when the program is first established and 'misuse' of resources in European terms - may occur and attract adverse publicity. However greater misallocation problems, which are harder to document, are likely to be diminished in the long run by the allocation of resources conforming more to Aboriginal tastes.

A compromise program could involve government departments granting responsibilities for determining the allocation of resources to local organisations. DCD, for example, could budget certain funding for water and roads to a group of outstations and allow the outstation organisation to nominate who would get water equipment and where the roads should be built. Similar schemes could exist for health and education resources.

Although this compromise program is much more realistic than the ideal program, we are a very long way from it at the moment. Thus, although in later discussions we are tempted to say leave it to the Aborigines' to decide policy issues, this would be a useless recommendation at present. Thus we have made recommendations where appropriate but these should be abandoned if they were disagreed with by an effectively constituted relevant Aboriginal body.

Finally, our expectation about employment opportunities at outstations has implications for the training and education of young people living on outstations. Under current circumstances, people living at outstations will have poorer education and training than those in communities or towns. Some points need to be made about this:

1. Some education of children is designed to produce people who can fit into European society. In the context of outstations, this is 
inappropriate and an outstation child missing this type of education may be better off. School often produces inappropriate status symbols and models, and causes disputes with parents and in the community. There is, however, a great need for education of the appropriate type.

2. The notion that giving Aborigines a European education results in them having 'a choice' between Aboriginal and European lifestyles is very naive, and especially for outstation children. Aspects of European education are, of course, necessary if Aborigines are to deal effectively with Europeans.

3. School curricula for outstation children must be sensitive to their environment and their likely future opportunities. Courses should include education in the local language, English, mathematics, manual arts, bush skills, and in later years instruction should be given in government institutions, European and Aboriginal history, politics and institutions. Instructors should include local people where possible. Local organisations should have a considerable influence on, or control of, the education process.

4. Many Aborigines have been through training schemes which have not led to jobs and some individuals have been through many such schemes without having a job which uses their training. There is no point in providing training schemes for people in outstations unless there is a real chance that an appropriate job will exist.

This concludes our discussion of. the general economic environment of outstations, and related matters. Now we turn to a detailed discussion of resources and land use on the outstations. The general conditions at outstations are discussed first, for their intrinsic value, and because they are important in determining land use. We begin with the Pintupi Homelands. 


\section{Pintupi Homelands}

\section{Background}

The outstation movement in the pintupi Homelands reflects the achievement of a long-standing desire of Pintupi people to return to their own country. Originally Aborigines belonging to the Pintupi linguistic unit occupied an area within about 200-250 kilometres west from Lake McKay. This tribal country merged east into country shared by both Pintupi and Walpiri, south into Pintupi/Ngaanyatjara country and north and west into Gugadja and Mardudjara country.

European contact with Pintupi people came fairly late in Australian history compared with other Aboriginal groups and as a result of this the Pintupi were the last group of Aboriginal people in Australia to leave their traditional country and settle in European created Aboriginal communities. The first European to meet the Pintupi was Carnegie in 1898 . This contact was rather unfriendly and the few Pintupis Carnegie met were captured and forced to lead the explorers to water (Carnegie 1898). Following this, other contacts with Europeans were sporadic, and in general Aborigines claim they were frightened and tried to keep out of the way of Europeans.

Until the late $1920 \mathrm{~s}$ and 1930s most of the Pintupi Aborigines continued to live within their own territory. Some however, had begun to move east, occupying land vacated by Luritja people who had moved to Hermannsburg Mission (Fry, 1933). The movement of Pintupi people away from their traditional lands increased in tempo during the 1930 s and early 1940 s and was stimulated by the establishment of a ration depot at Haast Bluff in 1941. By the mid 1950s, there were over 500 Aborigines camped at Haast Bluff. The bulk of these were Pintupi. In 1955 the water at Haast Bluff was declared undrinkable and as a consequence the people there were moved to a new government community at Papunya. By 1959 only 65 people remained at Haast Bluff. Over the next seven years the last 100 or so Pintupi remaining in the desert were settled at Papunya (Myers 1976; Penny et al. 1977; Stead 1982; Nathan and Japanangka, 1983).

This 20 year period of contact for the Pintupi people was most unpleasant and characterised by considerable tension and depression. The bush Pintupis were treated with disdain by other Aboriginal groups and fights were common. They were unable to adapt to European food and malnutrition was widespread. The death rate was very high. There were problems of over-crowding, poor hygiene and chronic problems with alcohol and juvenile petrol sniffing. Such factors provided the fuel for Aboriginal riots at Papunya in 1960, 1970 and 1972. Even today life at Papunya is so unpleasant it is difficult to get anybody, black or white, to stay there for very long (see Penny et al. 1973; Myers 1976; Long 1970; Nathan and Japanangka 1983).

To lessen the stress encountered at these settlements the Pintupi people separated themselves, as far as was logistically possible, from other Aboriginal groups at these communities (Myers 1976). They found life at Papunya dreadful and not surprisingly have always been keen to return to their own country (Stead 1982; Nathan and Japanangka 1983). The reason the 


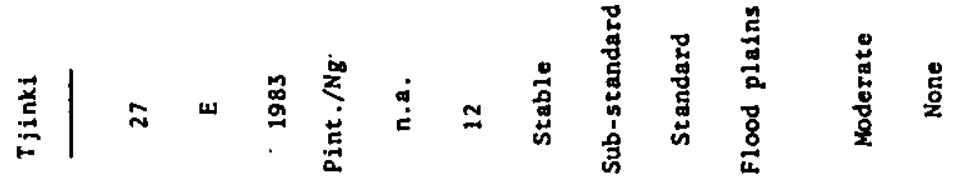

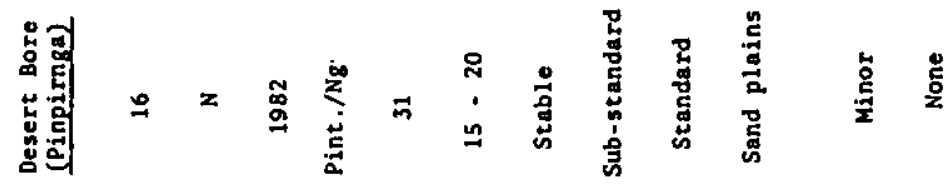

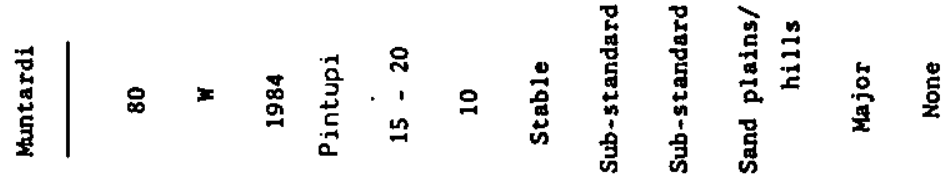

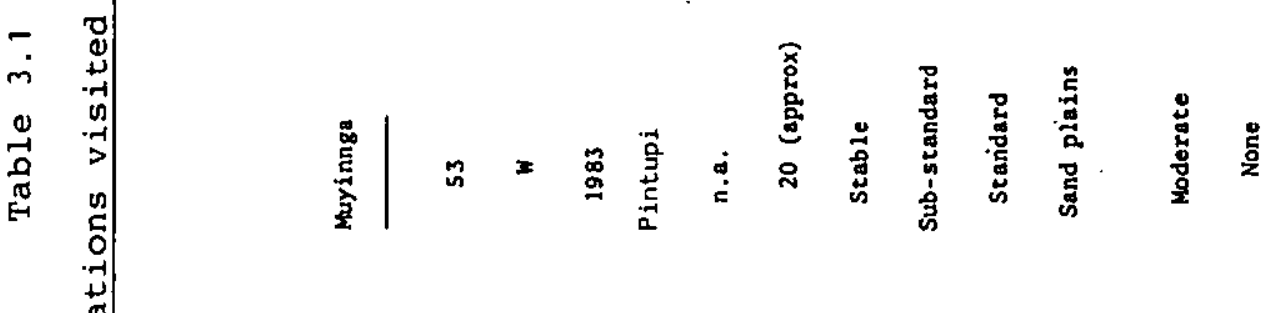

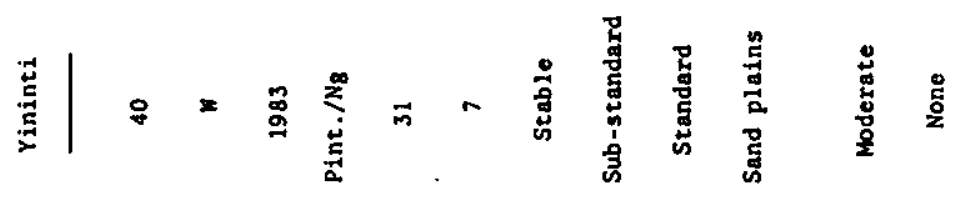

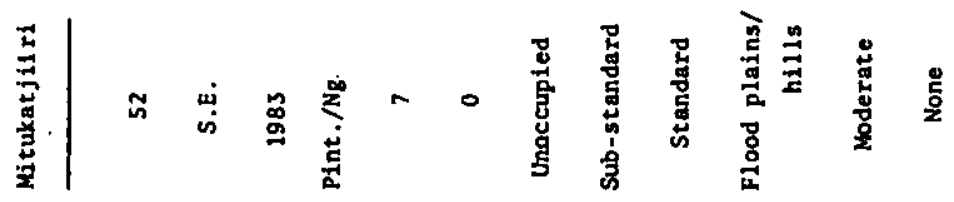

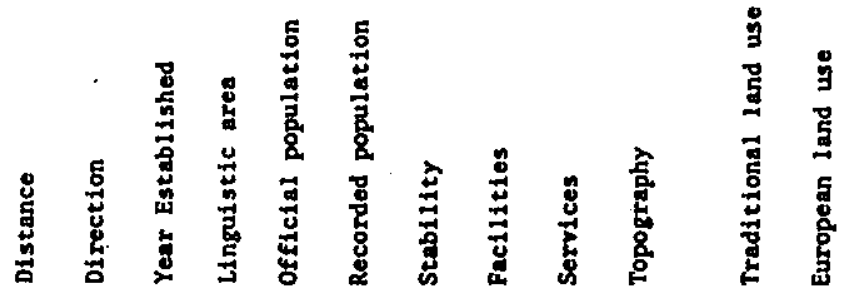


Pintupi people left their country in the first place is often debated. Generally, the view is held that they were pushed of $f$ the land by droughts in the 1950s and 1960s (Myers 1976; Kimber 1982) but this view has been challenged forcefully by Nathan and Japanangka (1983) who argued that the remaining Pintupi people were not starving but were 'trucked in' by a series of patrols conducted by the Native Affairs Branch and the Weapons Research Establishment. This may or may not be true and in any case only accounts for about one $f$ ifteenth of the original Pintupi population living in the bush (see Birdsell 1970 and Moyle 1979 for population estimates). We imagine that the bulk of the Pintupi 'walk in' was probably quite voluntary. The Pintupis probably had no idea how difficult life was going to be at settlements and probably had no intention of staying at settlements anyway (see also Tonkinson 1974). The abundance of food and water at Papunya and Haast Bluff and other communities such as Balgo and Yuendumu must have been very hard to resist for people from such a marginal environment. Nevertheless, the end result was that many Pintupi people found themselves at Papunya where the quality of life was grossly unsatisfactory.

Thus the Pintupis, along. with other Aboriginal groups living at Papunya wanted to get out and the outstation movement began in this region. This movement was fuelled by additional factors such as a strong desire to look after traditional country, care for places of religious importance and the desire to live again in their own land. These combined factors meant that no sooner had all the Aborigines been settled at Papunya than they began to move away again. The first move came in 1966 when a number of Pintupis went to Alumbara Bore. In 1968 approximately 200 Pintupi went to Waruwiya, but returned to Papunya when a spearing and car accident resulted in deaths (Myers 1976). In 1971 a large scale movement of approximately 200 people went to Yai Yai (60km west of Papunya). By 1974 the Pintupis had moved further west to Kungkayunti (Moyle 1979). Between 1975 and 1978 the population of Pintupi people began to fragment further west to Inyilingki and Mt. Liebig. By 1981 they had pushed further to New Bore, Warren Creek and Ilpilli (200 km west from Papunya; Figure 4.1). Kintore itself was established in 1981 (see Stead 1982; Kimber 1982).

\section{Kintore}

The establishment of Kintore marked the achievement of the goal of Pintupi people in establishing a 'main place' on the edge of Pintupi country - a base from which mechanical, health, economic and educational resources could be supplied to a constellation of outstations in the heart of Pintupi country. Consequently, the Pintupis have pushed Kintore which has grown physically (rather than demographically) over the last three years to meet this end. The changes over the last few years have in fact been quite substantial. Originally, for example, there was only one hand pump servicing 200 people whereas now there are two bores, two 5,000 gallon tanks and $2.5 \mathrm{~km}$ of reticulation at the camp. Similarly the store, which was once in the back of an old truck, now consists of a large shed with two large cool stores, two freezers and a full time store keeper. There are now four toyotas, several trailers, one tractor (broken down), a truck and ten radios (three of which belong to outstations near Kintore). The road is in good condition and there is a good airstrip. There is a power plant, a health service with a full time doctor, two sisters and a health administrator. There is also a builder, a full time teacher, visiting teacher and community co-ordinator (D.A.A.file $81 / 125(3)$ ). Clearly therefore Kintore is moving towards the service centre that has always been envisaged by the Aborigines. Yet it still has a way to go. The appearance of Kintore is extraordinarily rugged by European standards and certainly has fewer 
facilities than most Aboriginal camps of this size. For example, there are 316 official residents at Kintore and 280 of these live in sub-standard dwellings (humpies). There is no effective method of sewage disposal, and there are no ablution blocks. There are no mechanical services, the school is very poorly equipped and only consists of a couple of sheds. The lack of facilities and services at kintore is highlighted if one compares them to a community such as Jay Creek where there are only 56 people. Here there are nine houses and six pre-fabricated houses. No one lives in sub-standard accommodation. There is sewage disposal in septic tanks, water reticulation to all dwellings, an effective drainage system, and the service of radio, telephone and television.

The material discrepancies between the two camps are obvious. However Kintore is in a different situation. One reason for this is that the Pintupi people display a very obvious desire to retain old traditions and to be left alone to run their own affairs. At the same time, they express a desire for services and facilities that are invariably administered and run by white Australians. Presently the 300 people at Kintore have relatively few facilities, and only need the skills of half a dozen Europeans to run them. This compares to the community of 240 Aborigines at Ernabella who enjoy excellent facilities but employ 60 Europeans to run them. One wonders to what extent the inhabitants of Kintore will compromise their independence to attain extra services and facilities.

\section{Camps from Kintore}

Since the establishment of Kintore in 1981, another nine outstations have been set up in the Pintupi Homelands. The bulk of these are venturing further west into Pintupi territory and, from east to west, include Desert Bore, Yininti, Muyinnga, Mantarti, Yumari Bore, Winparku and Wala Wala. Wala wala (Kiwikurra) is over $200 \mathrm{~km}$ from Kintore and is located amongst the Pollock Hills in the heart of the-Gibson Desert. The Aborigines are anticipating the development of this site as another resource centre to service new outstations established in the western Desert. It is likely that outstations will develop in the north towards Balgo and west towards the Pilbara. Another two outstations are located east and south of Kintore. These are Tjinki and Mitukatjiiri respectively. The outstations we visited for this project were Mitukatjiiri, Djinki, Desert Bore, Muyinnga, Yininti and Mantarti (Fig.3.1).

Number and composition

\section{Population}

There were people living at all the outstations we visited from Kintore, except Mitukatjiiri. Here the owner complained that the water was 'no.good' and thus the people were spending a lot of time at Kintore. At the other camps the population varied from five to 20 people. These groups appeared stable and well established although the population figures were lower than official estimates. The age structure and sex composition of these groups seemed well balanced and there was a sizeable proportion of children at each camp. The largest groups were at Muyinnga and Desert Bore. At Desert Bore there were five families and we estimated between 15 and 20 people of all ages. It was difficult to count the people accurately at Desert Bore, because we brought half a dozen people with us and many children. Consequently there seemed to be people walking all over the place. At Muyinnga there were 20 people. This group consisted of five men, three middle aged women, four single women, three old women and four children under the age of 16. At Mantarti there were two families composed 


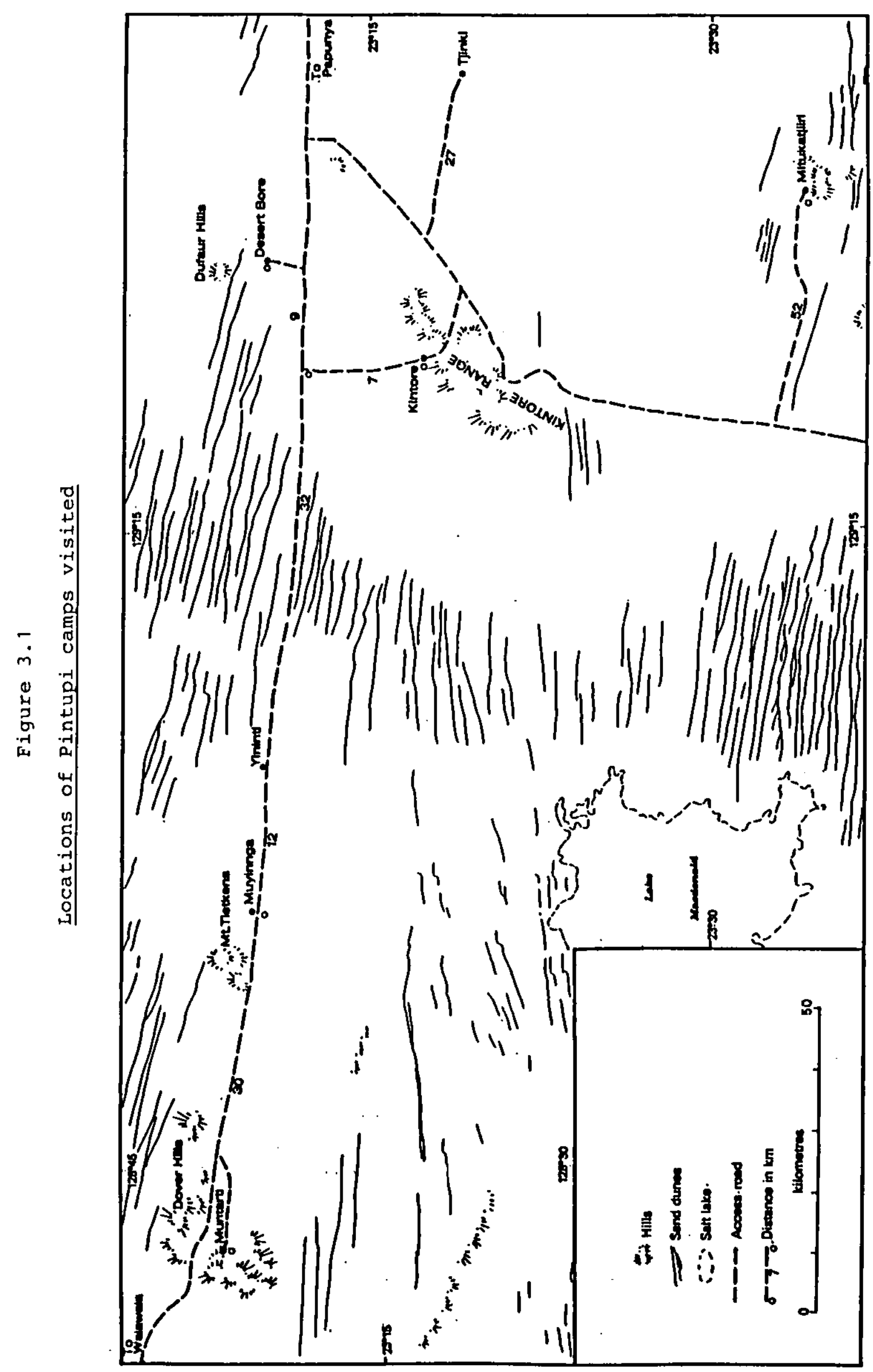


of two women, two men and six children under 16. There were twelve people at $\mathrm{Tjinki}$, consisting of six old men and women and six children under ten. At Yininti there were only three old women and two young boys. The owner of this camp and another man were hunting nearby on foot.

$\underline{\text { Stability }}$

A characteristic of outstations in all the regions we visited was the marked fluidity of movement between camps and the main community. As mentioned already, the population in these camps appeared stable, but people continually moved between camps, visiting friends and family, delivering food or going hunting. While we were in Mantarti for example, the younger brother of one family arrived unexpectedly with store food for the group. Also at Muyinnga people who normally reside at walawala were camped there on an extended visit.

The thing that struck us about the people living on these outstations was that they were still very nomadic; that they were naturally inclined to move from camp to camp fulfilling ceremonial obligations and visiting friends and relatives. This kind of contemporary nomadism was nowhere more apparent than at kintore itself. In the week we spent there, a truck-load of about 20 people went to Balgo, and returned a few days later with about 20 different people from Balgo. A truck-load of Yuendumu men were camped out of town on their way to Docker River on 'business' and they were soon joined by about 15 men from $M t$. Liebig and 12 people from Inyilingki outstation near Papunya. A week after we left Kintore we were told that 119 people arrived at Kintore from Balgo on their way to Walawala (McGuiness pers. comm.). The greatest amount of movement at outstations occurred at those closest to Kintore, although obviously the availability of vehicles had a lot to do with population stability as well. At Desert Bore (l6km from Kintore) for example, the owner travelled daily to kintore, taking his children to school and working in the health clinic. This contrasted with the situation at Mantarti which was $80 \mathrm{~km}$ from Kintore. Here there was no vehicle and the people were obliged to 'sit down one place'.

The only evidence of any kind of instability in the outstation movement in the Pintupi Homelands was at Mitukatjiiri and Mantarti. At the former camp, as already mentioned, the people were spending a lot of their time at Kintore because they could not drink the underground water. At Mantarti the people had recently moved from the original camp of Tjitjurunnga on the main road. In both cases this instability would appear to be short lived. At Mitukatjiiri for example, the camps appeared to have been occupied just prior to our visit and the people were keen to get back primarily to watch out for a sacred site near by which had been vandalized in the past (see also Kimber 1982). At Mantardi, the owner indicated to DAA in 1983 that they were not keen to establish an outstation at Tjitjurunnga (DAA file 81/125 (3):83), thus the selection of the new site (Mantarti) was not really a surprise. The new site, is also more important economically and mythologicaliy and has the advantage of being of the main road. The move, at the risk of sounding cynical, also had the advantage of leaving a hand pump on the main road for passers-by (DAA file 83/050037:130).

Houses

Facilities

The Pintupi outstations were the newest we visited in central Australia. Not surprisingly, therefore these camps enjoyed fewer facilities 
than outstations we visited elsewhere. Despite this, all camps except Mantarti had been provided with two first stage houses. First stage houses are in fact tin sheds about $3 \mathrm{~m} \times 3 \mathrm{~m}$ in size with a door and louvre windows. They have two verandahs which are aligned to provide morning and afternoon shade. The numbers of houses supplied in this region are adequate at camps such as Yininti and Mitukatjiiri where there were not many people, but this was not so at Desert Bore and Muyinnga. At Desert Bore there were five families, most of whom were living in six humpies and two very large windbreaks. At Muyinnga most of the group were living in seven humpies and four windbreaks, made from sheets of corrugated iron, upturned halves of water tanks and tarpaulins (Plates 3.1 and 3.2 ).

The Aborigines living in the Pintupi Homelands seemed to like first stage housing very much and we did not see any that had been damaged. The value of first stage houses lies in the protection they provide for food and valuables from children and dogs. The Aborigines usually only camp in them during summer rains but sometimes camp under the verandahs and, with a little makeshift innovation, turn the verandahs into enclosed windbreaks. Traditional windbreaks are still popular during the dry season and at Yininti we recorded a large wooden framed windbreak almost $30 \mathrm{~m}$ long. The Aborigines also make bough shelters from local materials. These are basically a roof of brush thatch supported by posts, used to provide ventilated shade during the summer months.

\section{Water}

All the camps visited except Mantarti were equipped with hand pumps, tapping underground reservoirs of water. At Mantarti, a bore had been sunk and casing laid but the Aborigines were waiting for a hand pump to be installed. At the moment this group are using water transported from Kintore in eight 44 gallon drums. At the other camps the hand pumps seemed to provide an adequate service although at Desert Bore the people were very vocal about their desire for a windmill. They complained they had been waiting 'too long' for a windmill, that there were a lot of people at the camp and a good supply of water was needed for good health.

As already indicated the people at Mitukatjiiri said their water was 'no good' and were also transporting water from kintore in eight 44 gallon drums when at the camp. The people here complained the water 'made you like flagon' (drunk or hung over). On tasting the water we noticed it was coloured like tea and tasted strongly of iron. Subsequent examination of the water quality report for this bore revealed a very high iron content (34mg/l whereas WHO maximum permissible is only lmg/l), high turbidity or muddiness $(260 \mathrm{mg} / 1$ whereas WHO permissible maximum is $25 \mathrm{mg} / 1)$ and high fluoride content $(1.9 \mathrm{mg} / 1$ whereas wHO permissible maximum is $0.6-1.7 \mathrm{mg} / 1$ according to water temperature).

Curiously the people from this camp had signed a letter written to the DCD acknowledging the high iron content of the water and accepting it as the water supply. This is curious as the Aborigines clearly had no idea what the problem with the water was - and were not happy about living at the camp because of the water quality.

We have water quality data for three other camps in the Pintupi Homelands and all of these had unacceptably high levels of either fluoride, nitrate and/or dissolved solids (Fig.3.2). 


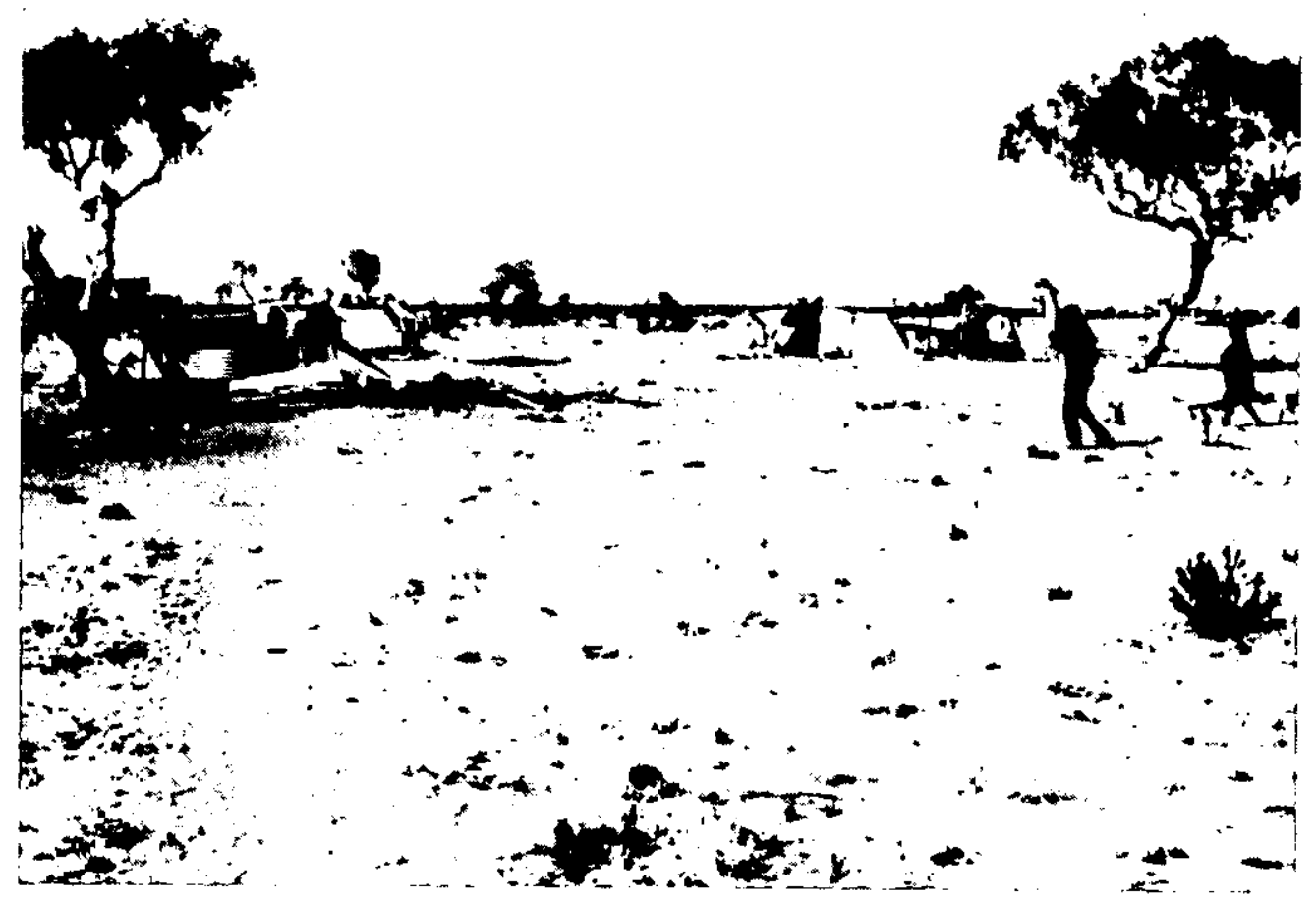

Plate 3.1 Aboriginal outstation - Muyinnga

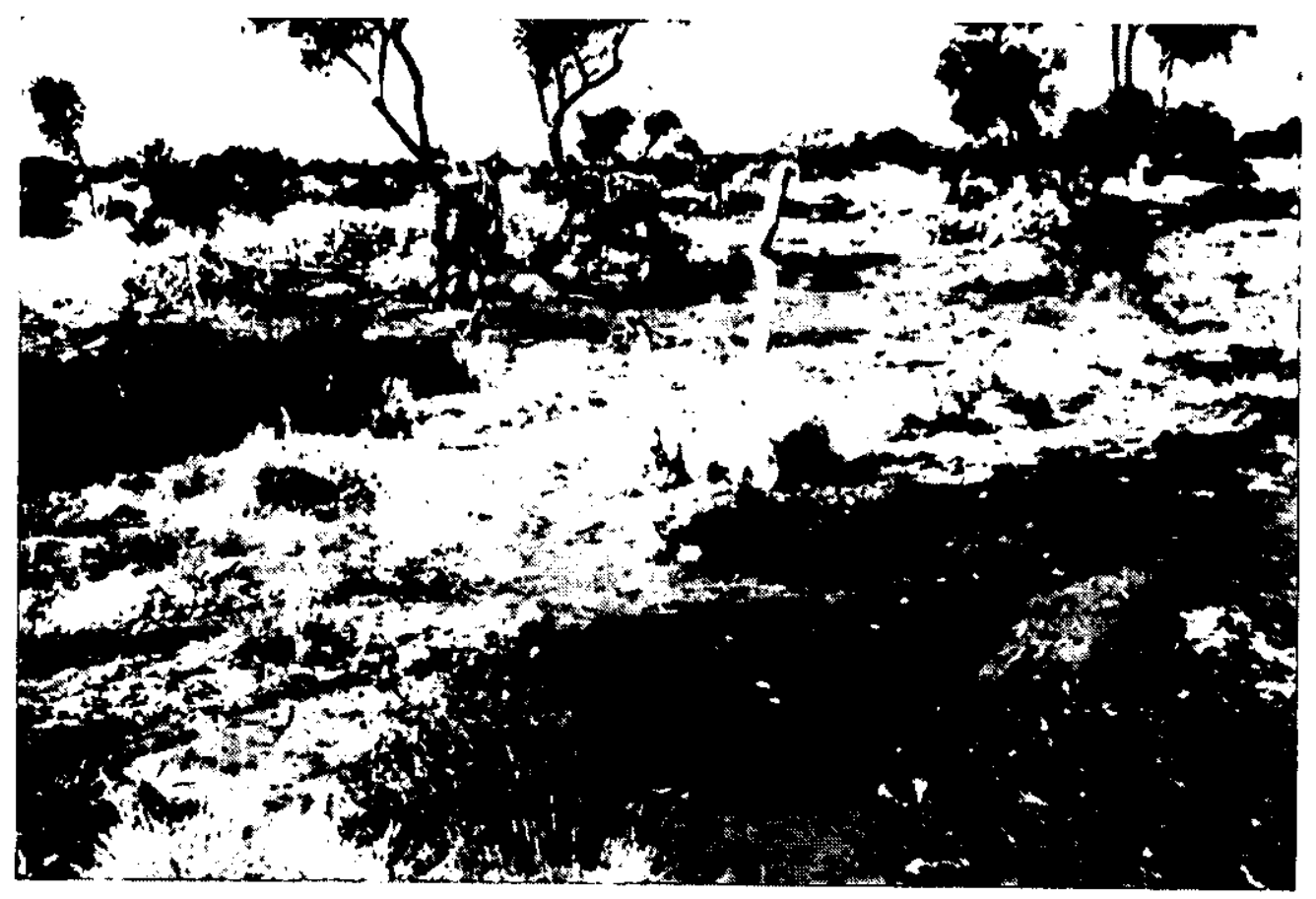

Plate 3.2 Aboriginal outstation - Muntarti 
Figure 3.2

Water quality at camps west in Pintupi Homelands

Nitrate

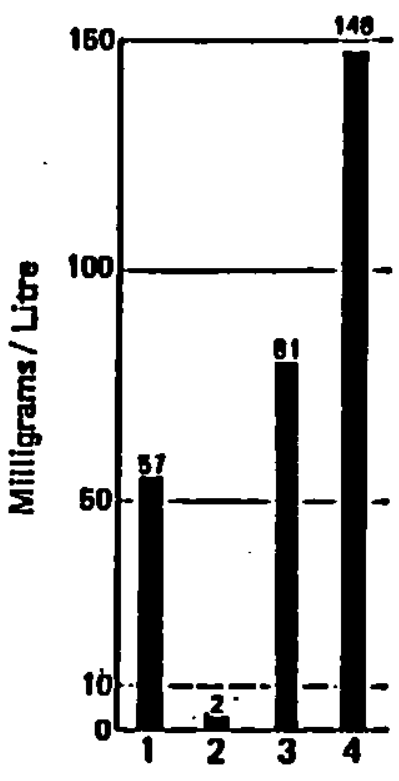

19.
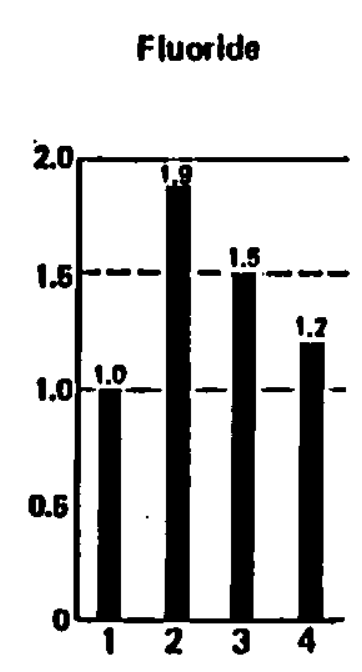

Location
Total dissolved sollds

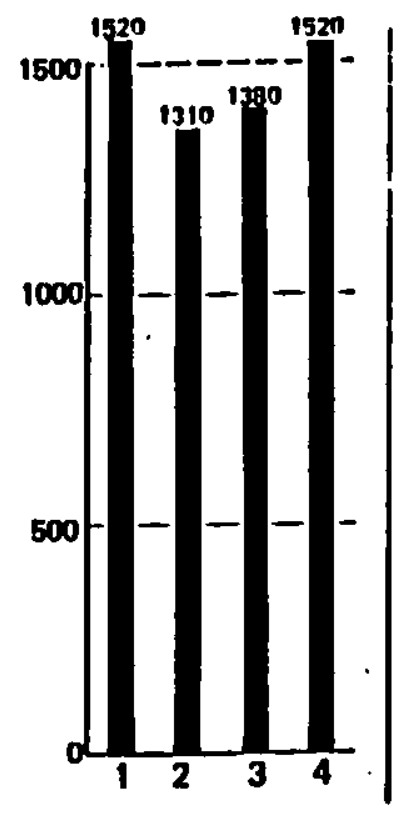

- - - - Mecomended maximim level

1 Ylnint

2 Mitukat|ilsi

3 Desert Bore

4 TJlnkl 
Radio Phones ('radios') and Toyotas

The Pintupi outstations we visited had relatively few radios and toyotas. As far as we could ascertain, only two camps had radios, Mitukatjiiri and Yininti. The only toyota was at Desert Bore and they were expecting another funded by the ABTA in the near future. The present vehicle was a private vehicle and was used, amongst other things, to transport workers and children to Kintore. The people at Mitukatjiiri, Muyinnga and Mantarti owned or had access to private cars but most of these were in appalling condition. There were no vehicles at Yininti or Tjinki and Mitukatjiiri.

Most of the roads in the Pintupi Homelands had been recently graded although the only access to $\mathrm{Tjinki}$ and Mitukatjiiri was over corrugated tracks and vehicle ruts in the spinifex. According to the standards set by roads in other parts of Central Australia, the roads in the pintupi and other Aborigine Homelands are pretty bad. As a consequence, the life of vehicles (particularly the old Holdens Aborigines invariably seemed to own) is very short. This is aggravated in this region by the absence of a mechanic at Kintore and the fact that Aborigines are unquestionably harsh on vehicles. We frequently saw heavily overloaded vehicles being driven out of tune, on under-inflated bald tyres, with flat batteries and low on oil and water. Nevertheless, the conditions are so harsh that no one expects vehicles to last long. Even the vehicles belonging to Europeans, which are much newer and better cared for than than those of the Aborigines, are due for replacement once they have done about $50,000 \mathrm{~km}$. With the exception of new vehicles, brought with ABTA funds, most vehicles have done twice that distance before Aborigines can afford to buy them. The following experience at Kintore has relevance here. When travelling back from one outstation late one afternoon we passed two new Ford four wheel drive vehicles parked on the side of the road. The vehicles were covered in sponsorship advertisements and were driven by young, white Australians who were 'going across the Centre mate'. It struck us that this was a classic 'outback' experience; man and his technology pitting himself against the dangers of the harsh interior. The vehicles were laden with gear - spare water and fuel, two way radios, refrigerators, tools, fold away tables and chairs, built-in beds and so on. There is a great difference between the gear Europeans consider necessary to travel and survive in arid Australia and the gear they are prepared to see Aborigines survive with. By the same token, however, we could not help feeling acutely embarrassed for the intrepid adventurers as they were constantly passed by Aboriginal families in old Holdens.

\section{Other Facilities}

Each of the camps we visited had differing quantities of hand tools and gear. Most of this was stored in houses or under windbreaks, so it was difficult to ascertain exactly what was where. Most camps had acquired piles of fencing wire and star pickets for fences and we noted that axes, crowbars and tarpaulins were rather common. Two camps ( $\mathrm{Tj}$ inki and Yininti) had small portable water tanks and at Mantarti there was a block and tackle. Some men at camps had rifles, but these were usually in poor condition. It was not uncommon to see guns in which the breeches were dirty, grips falling off and the sights either broken or battered so much they were useless. These guns struck us as very dangerous and largely ineffective. We recall on one occasion hunting bush turkey with such a gun. On this occasion the Aborigines fired away, but kept missing the bird. The gun eventually stopped altogether and was then passed back and forwards 
(loaded) in the vehicle while the problem was diagnosed. The gun was then dismantled, doused with petrol and put together again. The turkey stood by watching, so the men climbed back in the vehicle and started shooting again. They finished the remaining bullets but still had not hit the bird. They eventually got out of the car and chased the bird with tyre levers, but it flew away.

\section{Services}

The Aborigines told us that with the exception of the children at Desert Bore none of the children from outstations go to school unless they are in Kintore. The children at Desert Bore are taken to Kintore by the owner of the camp who works at the health clinic in the community. There are no visiting teachers at any of the outstations and the educational services at Kintore are inadequate for the 105 school age children living there. The school only consists of two sheds. There are only three fulltime teachers aides and one permanent teacher. Another teacher visits from Papunya two out of every three weeks. The local teacher has no vehicle and there was no budget for books and stationery. These were provided by Papunya school.

Kintore has established its own health service called the 'Pintupi Homelands Health Services'. They employed three health workers and one doctor. The doctor made regular visits to the outstations. Kintore also has a builder, but does not have a mechanic.

\section{$\frac{\text { Landscape }}{(T a b)} \frac{\text { and }}{1 e} \frac{\text { Land }}{2)} \underline{\text { Use }}$}

\section{Topography}

Topographically, the Pintupi Homelands are characterised by a general lack of relief. The bulk of the countryside is either flat sandplains or dune fields. The sand dunes align east south east to west north west and are relatively widely spaced and low $(3 \mathrm{~km})$. On the eastern side of the Kintore Ranges the sandplains are virtually dune free and here the plain is intercepted by small domes of granite, clay pans and broad bands of mulga.

Hills and ranges punctuate an otherwise horizontal landscape and often provide magnificent scenery. The largest range is the Kintore Range which rises $900 \mathrm{~m}$ above sea level and runs north-south for over $10 \mathrm{~km}$. Numerous steep, short creeks run from these hills and disappear into the surrounding plains. Lateritic and flood plains hug the base of the rocky ridges. The largest of these extends between Mt. Tietkens and the Dover Hills on the western side of the homelands. There are some large salt lakes in the general area. The largest of these is Lake Mackay to the north and this is approximately one quarter of the size of Tasmania.

\section{Climate}

The nearest comparable climatic data we have for the Pintupi Homelands comes from Yuendumu in the Walpiri Homelands (see Chapter 5). In this region the climate is characterised by hot summers and cold winters. Most rainfall occurs during the summer when tropical lows extend into the region bringing humidity, cloud cover and rain in the form of severe convectional thunderstorms. Winters are colder and rainfall significantly less, 


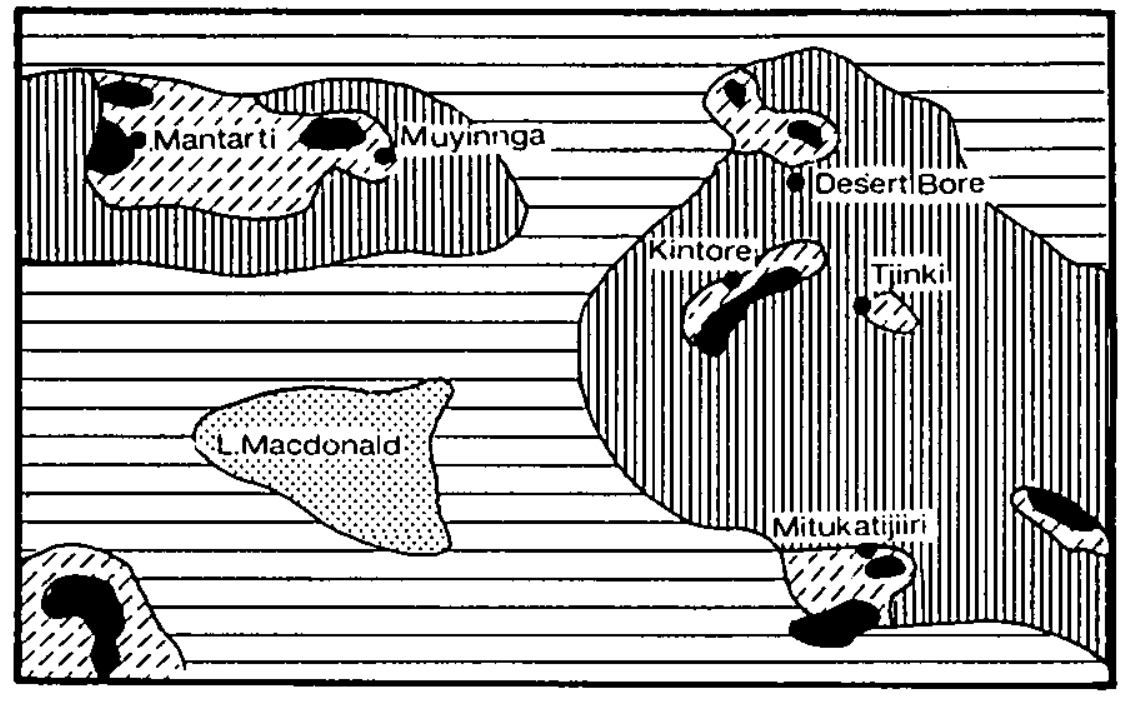

\begin{tabular}{|c|c|c|c|c|c|c|}
\hline UN!T & AREA & LAND FORM & SOIL & VEG̣ETATION & TRADITIONAL & EUROPEAN \\
\hline & large & $\begin{array}{l}\text { Sand plain: flat, undulating } \\
\text { plain: occasional clay pans, } \\
\text { low granite outcrops, little } \\
\text { surface drainage. }\end{array}$ & Red sand. & $\begin{array}{l}\text { Shrub steppe: Triodia pungens } \\
\text { dominant with scattered Acacia, } \\
\text { Grevillea, Hakea. }\end{array}$ & $\begin{array}{l}\text { Surface water. } \\
\text { reotiles, bustards, } \\
\text { stray kangaroo. } \\
\text { tubers, fire wood. }\end{array}$ & $\begin{array}{l}\text { Underground } \\
\text { water. }\end{array}$ \\
\hline & large & $\begin{array}{l}\text { Sand dunes: long, evenly spated } \\
\text { dunes; } 3.4 \mathrm{~m} \text { high running } \\
\text { eastwest. }\end{array}$ & Red sand. & $\begin{array}{l}\text { Ditto with Plectrachne schinzii } \\
\text { on dunes and pockets of blood. } \\
\text { wood (E. terminalis) and desert } \\
\text { oak (Casuarina decaisneana). }\end{array}$ & Ditto. & Ditto. \\
\hline \multirow[t]{2}{*}{ 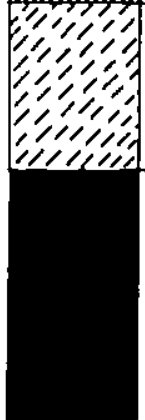 } & medium & $\begin{array}{l}\text { Flood plains, lateritic plains: } \\
\text { low, undulating plains, small } \\
\text { creeks, erosion gutters, wash. } \\
\text { outs and small clay pans. }\end{array}$ & $\begin{array}{l}\text { Red clayey sand. } \\
\text { laterite. }\end{array}$ & $\begin{array}{l}\text { Mulga dominant; various other } \\
\text { Acacia, Cassia spp. and grasses. }\end{array}$ & $\begin{array}{l}\text { Wood tor shelter; } \\
\text { fire and imple- } \\
\text { ments, kangaroos, } \\
\text { and bustards. }\end{array}$ & $\begin{array}{l}\text { Some nutritious } \\
\text { shrubs and grasses } \\
\text { could support } \\
\text { stock. }\end{array}$ \\
\hline & small & $\begin{array}{l}\text { Rocky ground: sand stone hills } \\
\text { and mesas between } 50-300 \mathrm{~m} \\
\text { high; steep dissected, boulder } \\
\text { strewn slopes. }\end{array}$ & $\begin{array}{l}\text { Shallow stony } \\
\text { soil. }\end{array}$ & $\begin{array}{l}\text { Triodia longiceps dominant, } \\
\text { spinifex scattered Eucalyptus, } \\
\text { Acacia and Cassia spp. }\end{array}$ & $\begin{array}{l}\text { Water holes, wild } \\
\text { figs (Ficus platy- } \\
\text { Doda). native } \\
\text { tobacco (Nicotiana } \\
\text { benthamiana). } \\
\text { ochre and } \\
\text { pigments. }\end{array}$ & Nothing. \\
\hline & medium & $\begin{array}{l}\text { Salt lake: flat evaporative } \\
\text { basins, salt encrusted surfaces }\end{array}$ & $\begin{array}{l}\text { Salty waterlogged } \\
\text { clays. }\end{array}$ & $\begin{array}{l}\text { Samphire, salt bush and } \\
\text { Melaleuca. }\end{array}$ & $\begin{array}{l}\text { Occasional lenses } \\
\text { of fresh water: } \\
\text { soaks. }\end{array}$ & Nothing. \\
\hline
\end{tabular}

Table 3.2 Land Summary of Pintupi Homelands 
decreasing as winter progresses into spring (July to September) (Fig.5.3, Chapter 5). The climate in the Pintupi Homelands is more or less the same, although being further south the region receives more winter rain, less summer rain and less rain annually. Beard and Webb (1974:25) record the region receives about $200 \mathrm{~mm} /$ year with the evaporation well in excess of that. This is a true desert climate. Temperatures are comparable with the Walpiri Homelands. The summer maximums range between 36 and 42 degrees Celsius and minimums between 18 and 24 degrees Celsius. Winter maximums are equivalent to the summer minimums (18 to 24 degrees Celsius) while winter minimums range between 6 to 12 degrees Celsius (Bureau of Meterology 1974). occasional frosts are experienced in the region.

\section{Vegetation}

Botanically the Pintupi Homelands can be divided into mixed shrub steppe on the sandplains and dunes and low mulga woodland on the flood plains. Spinifex dominates the vegetation on the sandplains. Common shrubs include dogwood, gidgee, cork wood, and desert poplar. Thick patches of honeysuckle and mallees are also often found on the sandplains. The desert bloodwood and pockets of desert oak are frequently encountered on sand dunes and areas of thicker sand. Three economically important species of bush tomatoes are found on the sand plains. These include Solanum centrale, s. chippendalei and s. diversiflorum.

Mulga is the most common tree on the plains surrounding the hills and ranges. Associated species include Acacia cuthbertsonii, Cassia notabilis and Cassia oligophylla. vegetation is scarce on rocky ground and spinifex is again the dominant form of vegetation. Wild figs and native tobacco grow in shady crevices and sheltered overhangs amongst the rocks. Red gums often grow along creek lines in the hills. Bean trees grow along creeks in the sandplains and coolibahs grow in swampy areas of internal drainage inundated by wet season rains.

\section{Plants of economic importance}

Traditionally there were about 100 economically important plants used by the Pintupis (Cane 1984). Many of these have since been supplemented or replaced by European goods. Most obviously, the production of unleavened bread from wild seeds has virtually ceased with the introduction of flour. Also many of the traditional medicinal plants have been superseded by European medicines and plants with more utilitarian functions such as making rope and sandles have been replaced by better European products. Nevertheless many of the traditionally important plants are still in use in the kintore region. These include a variety of food plants and plants used for making wooden implements.

Foremost, perhaps, amongst all the food plants are three species of bush tomato (Solanum centrale, $S$. diversiflorum and $S$. chippendalei). These grow abundantly on the sandplains and respond well to fire and are quick to colonize cleared or disturbed areas. The latter was particularly true and for s. centrale which was common along road sides and in camps.

Another important plant used by the Pintupi growing on the sandplain are bush potato tubers. These are a particularly important crop to the north (between Balgo and Yuendumu) and as far as we could ascertain, the Pintupi Homelands were on the southern margin of the bush potato 
distribution. These tubers are therefore of more importance to people living on outstations around Yuendumu than to those around Kintore. Two other species of economic importance growing on the sandplain in the Kintore region include coconut apples (parasitic galls growing on the desert bloodwood) and witchetty grubs obtained from the trunks of desert poplars. Nectars are also gathered from various flowers - but the most important are the corkwoods and grevilleas. Another important plant growing on the sandplains is spinifex. The sap from this plant is converted to an adhesive resin by fire and used as a hafting agent on spears, spear throwers and repairing damaged wooden dishes and other implements.

A variety of edible plants are also found around water bodies. Two types of underground tubers are commonly collected in this environment. These include the native yam, collected seasonally in abundance along the banks of dry creeks, and the bush onion collected around creeks, swamps and clay pans year round. Two important shrubs which produce edible berries also grow around water courses. These are the bush plum and konkle berry. The latter was once an important medicinal plant and has a fragrant wood which is burnt as an insect repellant. Two economically important trees grow around creeks and swamps. These are coolibahs and bean trees. Coolibah trees are the main source of witchetty grubs in sandy desert country and the wood of the bean tree is soft and light and is used for making dishes (coolimans) and shields. The seeds of this tree are bright red in colour and used for decorating hair string necklaces.

In the Pintupi homelands, the flood plains are used primarily for collecting wood. Mulga is by far the most important tree growing in this region. It is used for making wooden implements such as clubs, shields, spear throwers and boomerangs. Dry mulga is an unsurpassed wood for domestic fires. It is very dense and burns easily and slowly. During the winter mulga trees exude great quantities of malt tasting sticky sap and this is avidly collected.

The two most economically important plants growing on rocky ground are the wild $f i g$ and native tobacco. The $f$ ig is widespread on the lee side of rocks and cliffs in this region and produces great quantities of fruit for several weeks towards the end of winter. Wild tobacco is collected from rocky shelters. The tobacco is dried and mixed with ash from the leaves of Grevillea stenobotrya, to make chewing tobacco.

Animals

Large animals are relatively scarce in the kintore region. The most commonly encountered and frequently caught are bush turkeys (Eupodotis australis). Emus and red kangaroos generally live amongst the mulga plains and populations of these animals concentrate around water holes during the drier months of the year. Men make frequent hunting trips in vehicles to catch kangaroos and consequently both kangaroos and turkeys are a regular part of the bush diet. In the larger hills such as the Kintore Ranges euros (Macropus robustus) are quite common and there are plenty of dingoes.

Apart from insects, lizards are the most common form of animal life in arid Australia. The largest and most economically important in the pintupi Homelands are two sand goannas (Varanus gouldi $i$ and $v$. acanthurus). Goannas are still very much a staple part of the diet in the Pintupi Homelands. 
There are not many introduced animals in this part of Australia. We did not see any evidence of rabbits and were told none existed in the general area. This is surprising considering they are common at Lake Hopkins only $100 \mathrm{~km}$ to the south. Nor did we see any signs of wild cattle, although we saw tracks of feral cats and camels. There are apparently more camels in the sand dune country to the west and on one occasion in this region we saw a herd of 17 camels walking through the dunes.

\section{Camp Locations and Land Use}

Three of the six outstations we visited were located on the sandplains. The remainder were situated amongst mulga plains near rocky country. All the camps were in close proximity (walking distance) to a variety of different ecological zones, and thus had access to many of the plants and animal species summarized above. For example Yininti was located on a sandplain and was between sand dunes to the east and mulga plains to the west. Desert Bore was also located on sandplains and south of Dufaur Hills and associated pediments, laterite and floodplains. Tjinki was located in the centre of a sandplain, but on an island between a vegetated swamp and a small clay pan in a large mulga covered floodplain. Muyinnga was also located among mulga plains, south of a heavily vegetated creek and within walking distance from Mt. Tietkens. This mulga woodland extended all the way from Muyinnga to Muntarti and was relatively good kangaroo country. Mantarti itself was nestled among the Dover Hills. This was an ideal location, surrounded by small breakaways (escarpments), clay pans, patches of mulga and sandy alluvial plains. The location thus presented a rich and diverse bush environment to hunt and gather in. Mitukatjiiri, in the south of the region was situated in a similar location, set amongst a thick grove of mulga, backing onto a low range of sandstone hills. Both these camps had access to supplies of bush turkeys, kangaroos, euros, hardwoods, wild fruits and goannas.

The Pintupi outstations had the most traditional flavour of all the outstations we visited. This manifested itself in ways such as the general layout of camps and the behaviour and dress of the people. It was common, for example, to see men wearing head bands with their hair drawn back from their foreheads in the traditional fashion. At one camp an old man was naked, bar a pair of small shorts, and completely covered in oil. It was common also to see children running around naked, playing with spears made from the traditional wood, sida virgata. Such characteristically traditional behaviour was particularly obvious in the food resources used at camps and by the obvious maintenance of the land by the traditional method of burning. As indicated at the beginning of this chapter, the Pintupi outstations are relatively new, but already large areas of desert have been burnt by the Aborigines in order to return the country to its former state of productivity.

The extent of recent burning is particularly apparent if one compares Figures 3.3a and 3.3b. Fig. 3.3a was drawn from satellite imagery taken in July 1981, before Kintore was established, and Fig. 3.3b in October 1983. In the former figure (Fig..3.3a), numerous old burns and some new wild fires can be seen. In the more recent figure (Fig. 3.3b) however, one can see a great increase of recent fires. Their geographic association with roads and/or outstations indicates their human origin and underlines the resurgence of traditional land management practices in this region. 
Figure $3.3 \mathrm{a}$ and $3.3 \mathrm{~b}$

Fire patterns in the Pintupi Homelands, 1981, 1983

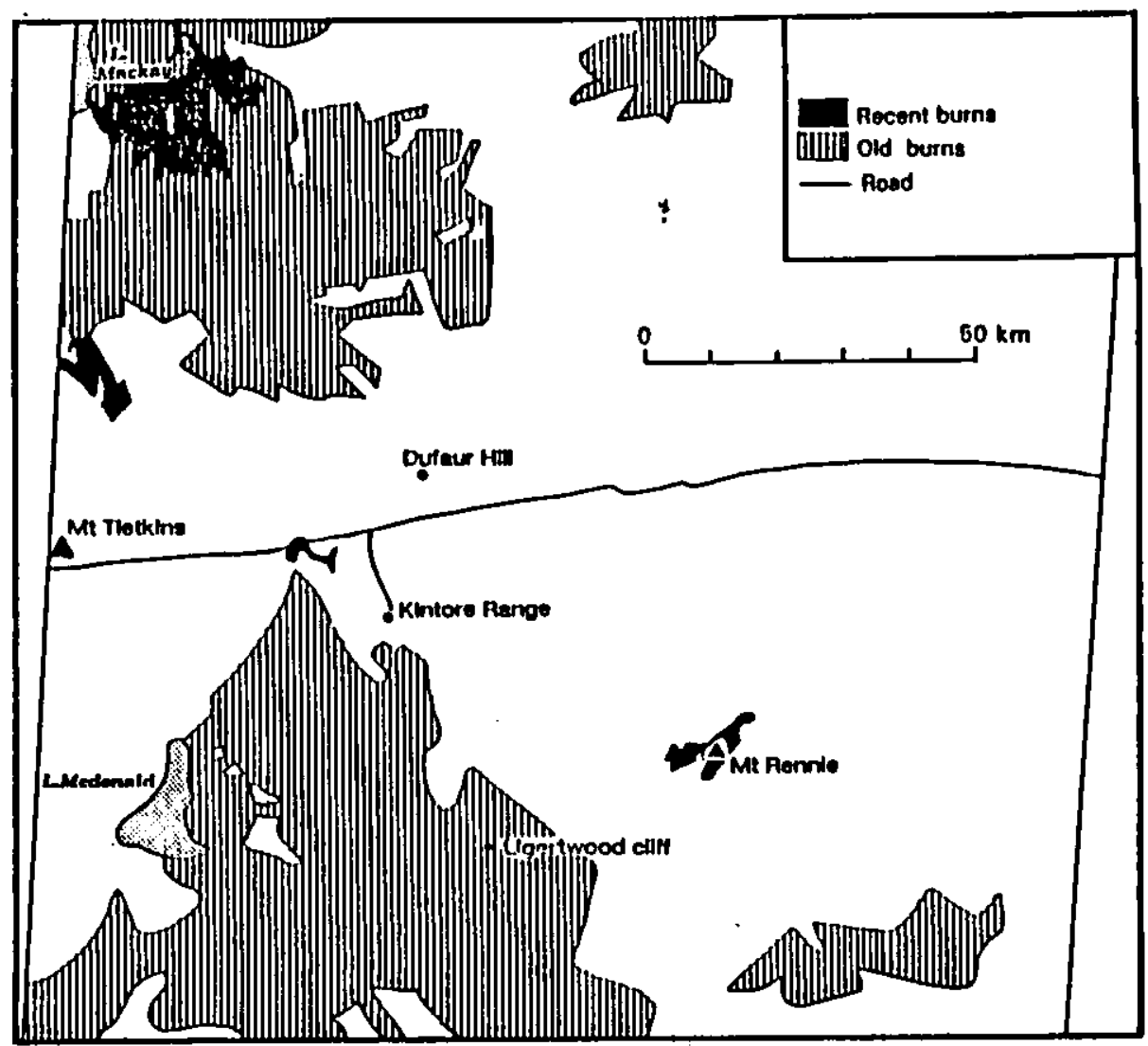

Figure $3.3 a$

1981

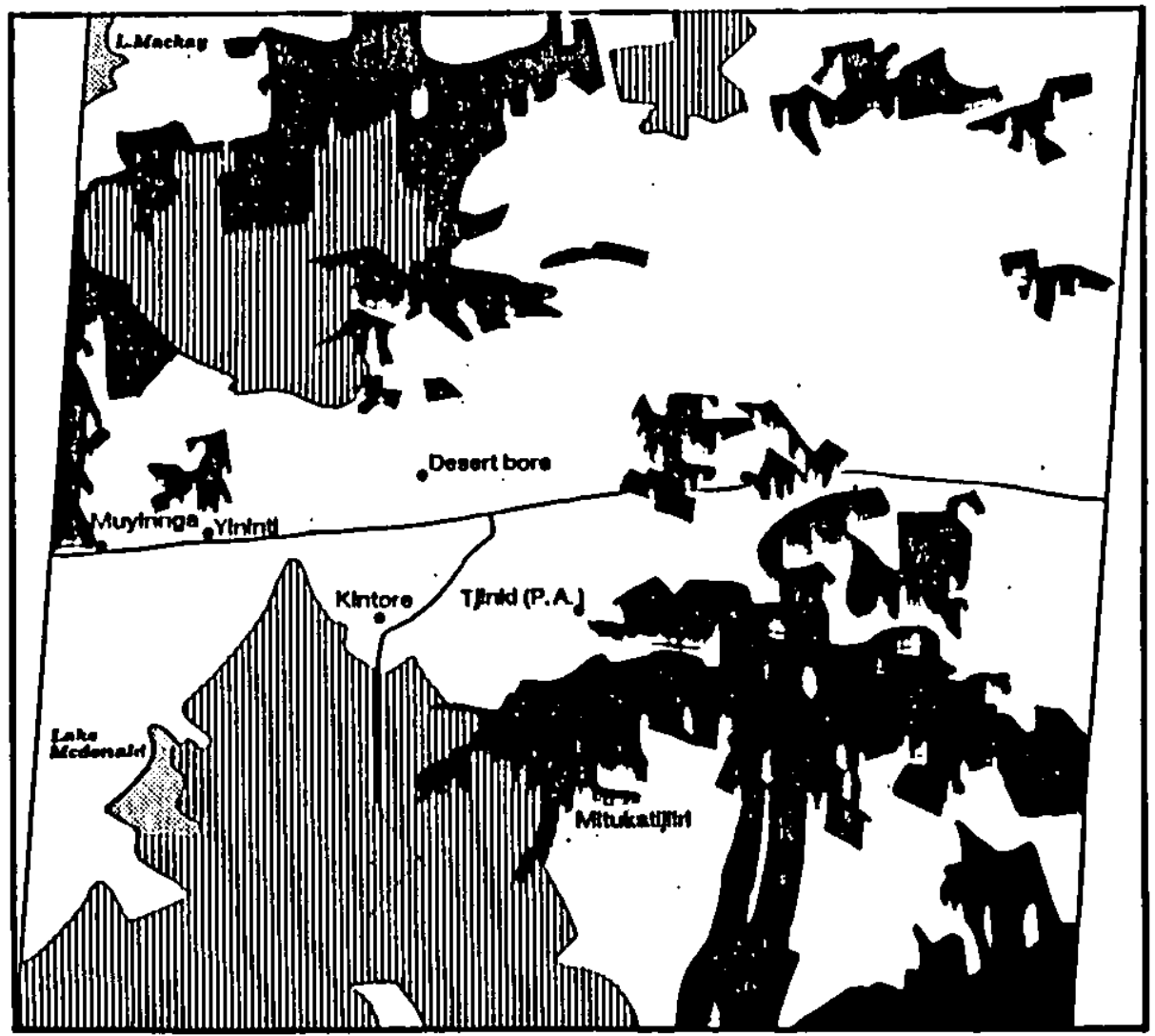

Figure $3.3 \mathrm{~b}$ 1983 
The role of fire in Aboriginal subsistence strategies is discussed in Chapter 8. Thus it is sufficient to note here that following fire, game is attracted to the burnt country, there is a marked increase in the quantities of edible vegetable foods and the ground is cleared, making goanna hunting easier and more profitable. Hence, in the Kintore region, one sees evidence of the Aborigines pursuing their goal of 'looking after' their country and making it fit for more traditionally orientated patterns of subsistence.

On the ground we noted extensive areas of freshly burnt country around Mitukatjiiri, Yininti, Muyinnga and Tjinki. While we were at the last three camps people were out hunting and smoke could be seen scattered within several kilometres of each camp. At Mantarti, the most recent camp, the country had not been as extensively burnt and the country south of Desert Bore appeared not to have been burnt for a long time.

Not surprisingly, given the burning patterns evident in this region we found a relatively heavy reliance on bush tucker among outstation dwellers. This reliance was not 'heavy' in the traditional sense, rather it was significant in comparison with outstations in other regions we visited. Unfortunately we were not in any camp long enough to gather quantitative data on the consumption of bush food compared to store food. Nevertheless, our impression was that bush tucker contributed substantially to the diet, contributing perhaps up to 50 per cent of the food consumed at camps (Table 3.1). This contribution varied somewhat according to the availability of transport and the proximity of camps to Kintore. Generally the closer a camp was to Kintore and the more transport available the more store food consumed at those camps. The reverse was also true. For example, at Mantarti people ate a lot of bush tucker. This was the most remote camp we visited and the people only had access to one dilapidated holden belonging to a brother at kintore. At this camp we saw evidence of euros, kangaroo, emu, turkey, witchetty grubs, goannas and coconut apples. This contrasted the situation at Desert Bore which was close to and in daily contact with Kintore. This camp was strewn with flour drums and the only evidence of bush food was some fresh kangaroo in camp and two cooking pits for kangaroo and turkey. At the other camps we visited we saw evidence for various combinations of European and Aboriginal foods. Camps were invariably littered with old cans of 'tin meat' and flour drums but at the same time there was evidence that the people were eating bush foods such as tomatoes, wild tubers, goanna, turkey and kangaroo.

The actual contribution of bush food at each outstation also fluctuated from week to week. The situation would often arise where someone would bring a load of store food into a camp and this would be eaten instead of bush food. Similarly, there was a distinct tendency to buy bulk store food on pay day and eat this until it ran out. Thus, more bush food seemed to be eaten in of $\mathrm{f}$ pay weeks than on the days following receipt of unemployment and pension cheques. Nevertheless even when there was a supply of store food people would complain they were 'hungry for meat' and go out hunting for goanna or kangaroo. Often they would simply go hunting and gathering to break the monotony of sitting around talking and playing cards.

Bush food requires more physical effort to get than store food and often people do not have the means (i.e. guns, bullets or cars) for obtaining substantial quantities of wild food. Both factors are important underlying reasons for the selection of store food when there is the money to buy it. However it is our experience that (with the exception of flour) if given a choice between a truck load of store food or a truck load of its 
wild equivalent (e.g. tin meat or kangaroo, oranges or bush tomatoes) the Pintupi Aborigines would generally choose bush tucker. Thus, our interpretation of the situation in the Pintupi Homelands was that bush tucker made a substantial contribution to the diet of people living on outstations.

In addition to obtaining food from their environment, the Pintupi Aborigines still use the desert to supply many of their material needs. For example they collect ochre and feathers from birds such as emus, cockatoos and fledgling wedged tail eagles for ceremonial decorations. There was also a vigorous trade from Jupiter well of a valuable resilient wood (Acacia dictyophleba) used for making spears. Softwood dishes were made from the wood of the bean tree and implements such as clubs, punishment spears, spear throwers, shields and boomerangs were made from mulga. Sturdy trees such as mulga, corkwood and desert oak and shrubs were commonly used in the construction of fences, shelters, windbreaks and summer shadeshelters. Yininti had the largest brush shelter we have ever seen. This was over $30 \mathrm{~m}$ long and stood $2 \mathrm{~m} \mathrm{high}$. It was built from a frame of corkwood and thatched with spinifex and bushes. The dense hardwoods in this region are also very important for domestic fires. Fires are important for cooking and for warmth at night and are usually left smouldering all day. The availability of firewood is an important factor to consider when selecting a site for an outstation and not surprisingly all camps were located near good supplies of firewood.

European Land Use

European practices of land management at outstations in the Kintore region are virtually non-existent. One aspect of outstation development that was characteristically European was a tendency to erect fences around each camp. This tended to make outstations look like concentration camps and appeared to reflect the European habit of parcelling of $f$ and assigning distinct ownership to pieces of land.. We gathered from the Aborigines that this was also an attempt to make their camps look nice in order to impress visiting Europeans like ourselves. Other attempts at European style camps beautification had been equally unsuccessful. At Yininti, water was drained from the spillage at the hand pump to a small red gum tree. Despite this, the tree was only about a foot $\mathrm{high}$ and looked in bad shape. Two bean trees had been planted at Desert Bore and these were doing a little better. Neither attempt had made much difference to the appearance of each camp.

The owners of Desert Bore and Mitukatjiiri, both expressed a desire to plant gardens at their camps. Both men stressed the necessity of first obtaining a windmill, tank and reticulation. They said a garden could not be effectively watered without a windmill and while this is true, we are inclined to think these men were using gardens solely as a lure to attract windmills.

One final aspect of the economic activities at outstations is the involvement of the Pintupi Aborigines in the production of art for sale through the Tula Artists at Papunya. In 1983 there were eight full time and 20 part time artists at Kintore (DAA File:81/123(30)). On the outstations we visited we saw two artists working on canvases at Muyinnga. One of these was very large $(2.5 \mathrm{~m} \times 3.5 \mathrm{~m})$ and was expected to sell for about $\$ 1,000$. We do not know what sort of annual income this provides individual artists, but we imagine it would provide reasonable subsistence for those directly involved. In 1976 Tula Artists only earned $\$ 16,500$ for its 22 members (Wilkinson 1981:68) but we expect that this income is substantially more now. 
Chapter 4

Luritja Homelands

Background

In the previous chapter the historical background to the Pintupi Homelands movement and its association with Papunya were outlined. The historical background to the Luritja Homelands movements has close parallels with the Kintore movement, the major difference being that the contact between European and Luritja people was a decade or so earlier. As indicated in the introduction to the previous chapter, Pintupi people had expanded east, as early as the 1930s, occupying land near Mt. Liebig that had been vacated by Luritja people (Fry 1933). Prior to that, Luritja people had begun to drift towards Hermannsburg Mission, which was established in 1877, and to Glen Helen Station, one of the first stations set up in the Northern Territory and established before the turn of the century. In the early 1930s three camel patrols were sent from Hermannsburg to look for Aborigines in Luritja country and reached as far as Putarti and Ilpili Springs (Fig. 4.1). By the 1940 s the bulk of the Luritja people had vacated their land.

Some Luritja Aborigines moved from Hermannsburg and Glen Helen following the establishment of a ration depot at Haast Bluff in 1941 and subsequently many shifted to Papunya when it was established in the late 1950s (Penny et al. 1977). The Luritja Homelands movement then followed the Pintupi exodus, being motivated by more or less the same forces and desires. At Kungkayunti for example (a camp occupied by both Luritja and Pintupi people) the most commonly stated reason for leaving Papunya was the Aborigines' desire to distance themselves from drinking and fighting, to return to a traditional way of life and to be removed from constant white supervision (Morice, 1978:56).

The Luritja Homelands movement thus grew alongside the Pintupi movement and from the early camps at Yai Yai and Kungkayunti (see Chapter 3) established itself independently within an approximate radius of about $70 \mathrm{~km}$ west from Papunya. It appears that there were only five outstations near Papunya in 1975 (Table 5.1), but these were relatively large, accommodating approximately 300 people. By 1976 and 1977, the number of outstations had grown to eight and their total population was about 500 . This was half the 1970 population at Papunya. The years of 1978 and 1979 saw a boom in outstation development and another five outstations were established in 1978 and another three were established in 1979. It appears that 16 outstations were occupied near Papunya in 1979. This total fell to nine in 1980; grew back to 11 in 1981, but had dropped to only seven in 1982. By 1983, nine outstations were being occupied. At the time of our visit in 1984, there were 12 outstations of which four were occupied (new Bore, Mt. Liebig, Warampi, Alkipi); four were unoccupied, but in use (Inyilingki, Ulumbarru, Black Water, Kungkayunti) and four appeared to have been abandoned for some time (Ili Ili, Ilpili, Warren Creek, Five Mile).

Thus one sees considerable fluctuation in the history of outstation occupation in Luritja country - a situation which seems to have been characterized by a sequence of boom, bust and re-establishment. Because of this, the Papunya Homelands movement has a reputation for instability although the camps now in use appear to be cohesive and, according to the life-style characteristics of traditional nomads, relatively stable. 


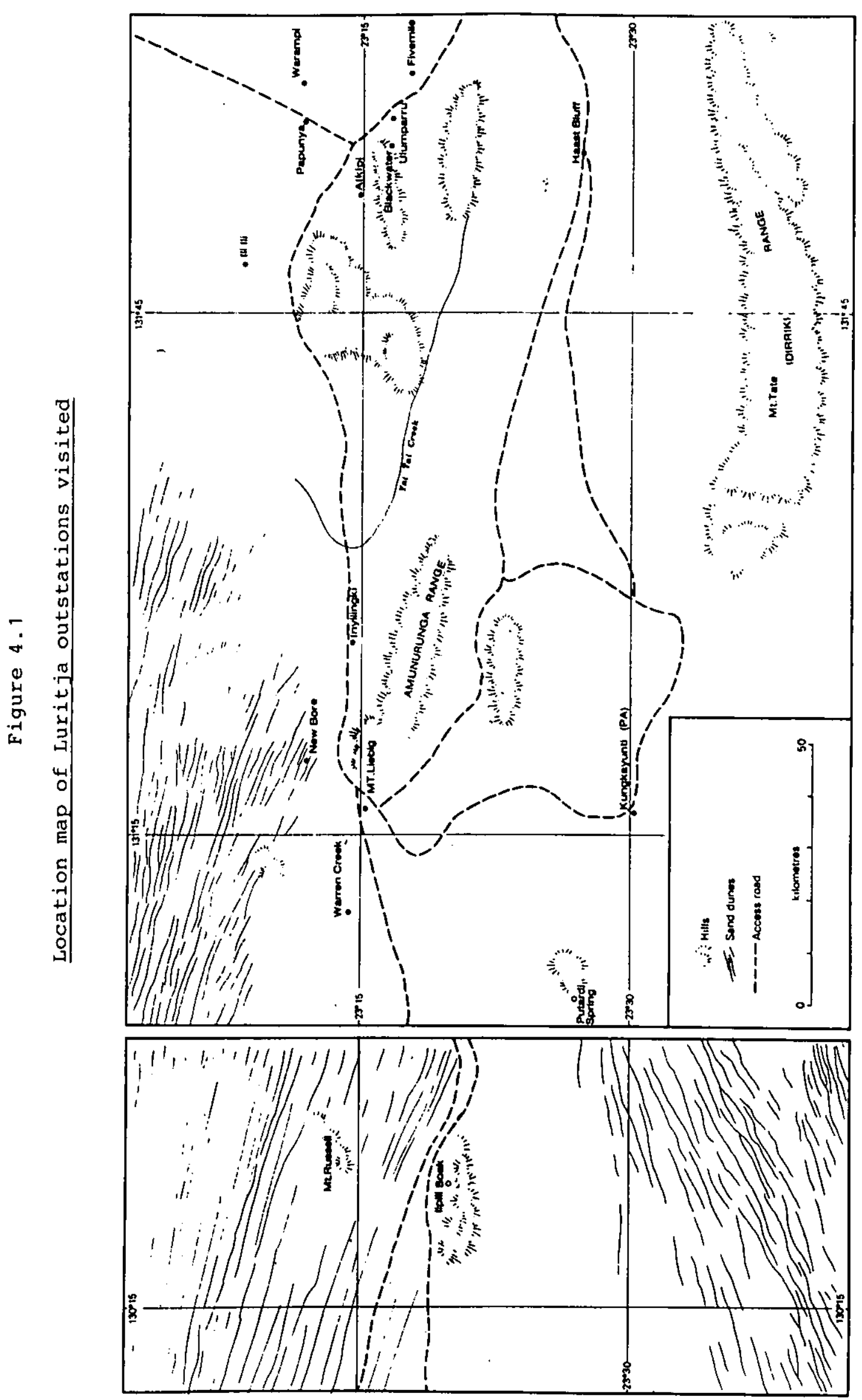




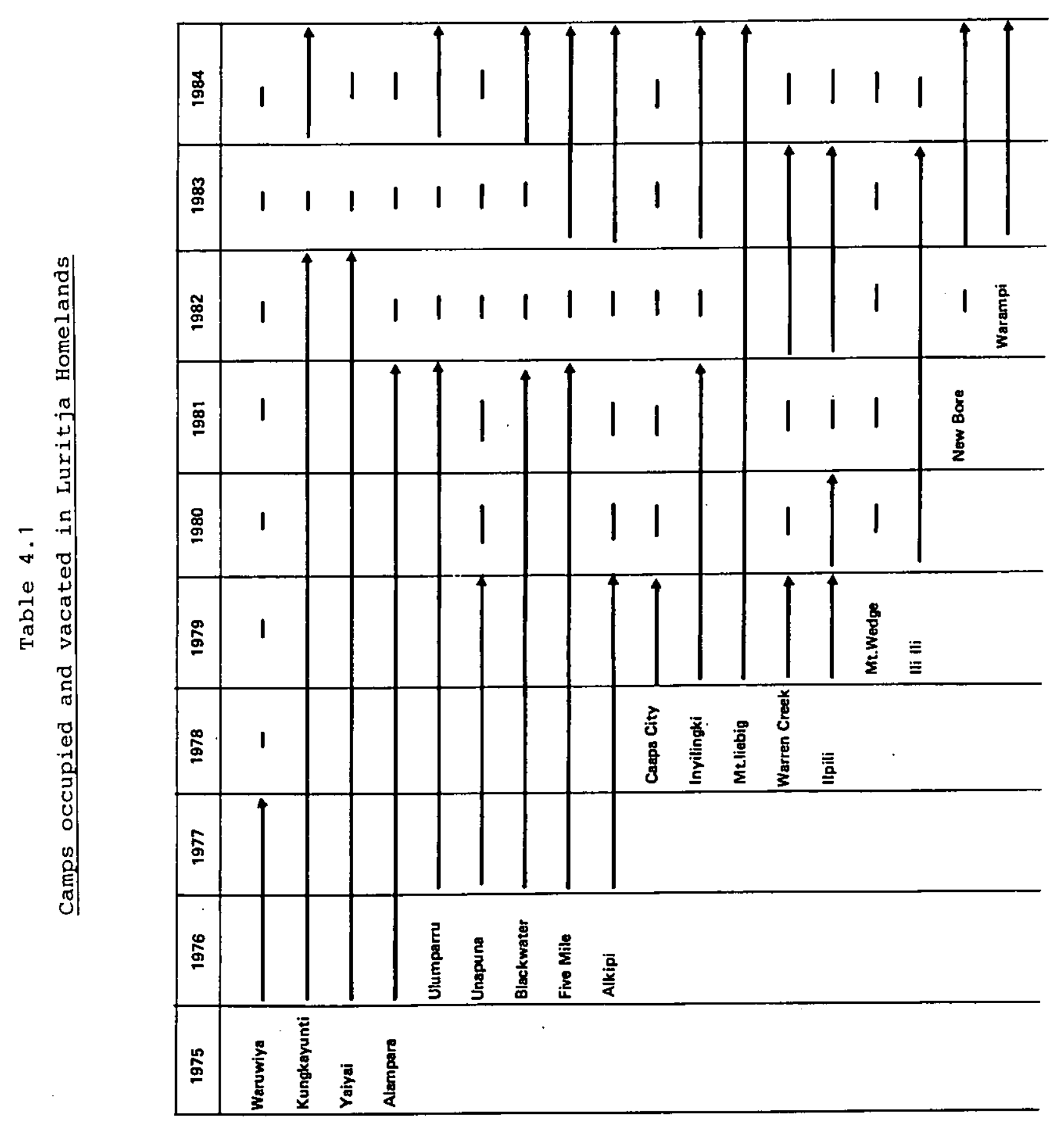


The original instability appears to have been largely the result of the dislocation and vacuum caused by the movement of Pintupi people from the Papunya outstations towards Rintore in the late 1970 s and early 1980s (see also Nathan and Japanangka, 1983). Reflecting upon the historical background to this instability, it seems that the situation could almost have been anticipated given the long-standing desire of the Pintupi people to establish camps in their own homelands. In fact, the instability and waste of resources associated with this period of flux may have been avoided completely, if government departments had bitten the bullet initially and provided basic facilities directly in Pintupi country as advocated by Long (1957) and requested for so long by the Pintupi people. It is common to hear the view from Europeans that the Aboriginal people in this homeland region do not have sufficient commitment to their outstations. It is our view that 'lack of commitment' is an inappropriate characterization of the nature of the development at these outstations during this period. It appears that the Pintupi were using outstations in the Luritja country as stepping stones leading towards their own country and the Luritja were expressing the same strong sense of territorialism by constantly pushing the Pintupi away from the Luritja Homelands towards Pintupi country. Thus the notion that this instability reflects an irresponsible attitude to camps and a disregard for what Aborigines profess to be deep rooted concern for their country and sacred sites is not accurate. Seen historically this period of instability reflects a cogent territorial and neo-territorial spirit on behalf of Aboriginal people; not a lack of commitment to the Homelands movement in general.

In addition to the dominating influence of the kintore movement, the smooth development of camps in the Luritja Homelands was also punctuated by other unfortunate social and environmental factors. These included the abandonment of Ilpili and Alkipi to a new camp at Ili Ili because. of deaths. In 1981 the well at Unapuna dried up and the people from there also went to Ili Ili and a new camp at Warampi. Consistent occupation of the early camps at Ulumbarru and Black Water was hampered by inadequacies of the natural water supply. People moved from Kaapa City because this outstation was outside the Haast Bluff Reserve. Five Mile was more or less abandoned for several years following the death of its original leader and its present population suffers continual problems with alcohol.

Thus one can see a constant interplay of social and environmental problems which plagued the development of outstations in the Luritja Homelands. These factors have meant that over the last ten years, six for 33 per cent) of the 21 outstations established around Papunya have been completely abandoned (Table 4.1).

In recent years there appears to be a re-focussing of the outstation movement in the Luritja Homelands. Since 1982, for example, one sees the re-establishment of outstations at Alkipi, New Bore, Ulumbarru and the consolidation of historically cohesive groups at Kungkayunti, Mt. Liebig, Warampi and Black Water. These camps appear to form the enduring core of the Luritja Homelands movement.

\section{Luritja camps}

During our two week visit to Papunya, we visited 12 outstations (Table 4.2). Half of these were located within a $20 \mathrm{~km}$ radius of Papunya and included Warampi (Three Mile), Five Mile, Ulumbarru, Black Water (Alturu), Alkipi and Ili Ili. An additional five camps were located between 50 and $80 \mathrm{~km}$ west from Papunya. These were Inyilingki, New Bore (Wadiyawanu), Mt. 


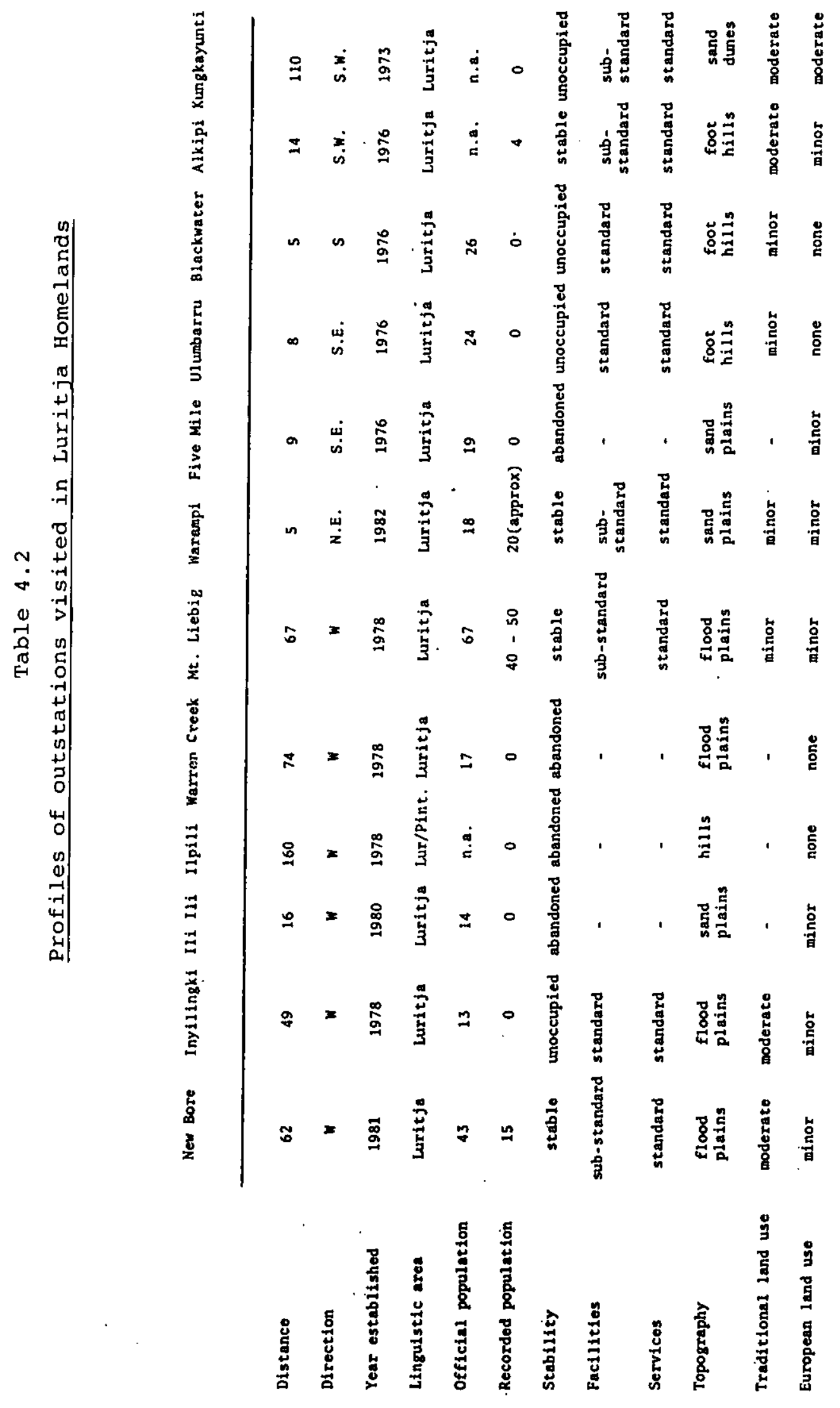


Liebig (Yamundurrungu), Kungkayunti and Warren Creek. The twelfth camp, Ilpili, was located half way to kintore, $160 \mathrm{~km}$ from Papunya (Fig. 4.1).

With the exception of Ilpili, all these outstations were located in the heart of the Luritja country. In fact the Luritja people at several camps made this very clear and asserted an unusually strong sense of ownership and belonging. This is not surprising considering the relatively long history of Pintupi presence in this area. Ilpili was located to the western margin of the Luritja country, $1 \mathrm{~km}$ north of Ilpili Spring in the Ehrenberg Range. This spring is one of the few permanent water resources in the region and was once an important 'living water' in times of drought. Traditionally, the spring was shared by Luritja, Pintupi, Pitjantjatjara and Walbiri people.

Some of the Luritja camps are amongst the oldest in Central Australia. Kungkayunti, for example, was established in 1973. It was originally located at 'Browns' cattle bore, but has since been relocated $1 \mathrm{~km}$ to the south. As far as we can ascertain, Ulumparru was established in 1975, but has since been moved from its original site because the natural water supply was insufficient for the needs of the group. Blackwater and Five Mile were established in 1976. Originally, the people at Five Mile were described as the 'most energetic mob' of all outstation groups near Papunya (DAA 76/12(2):21), but since the death of the original owner interest in the camp has declined and there have been recurring problems with alcohol. Blackwater has been consistently occupied since its inception although this group is only $5 \mathrm{~km}$ from Papunya and they commute regularly to the settlement.

Alkipi, Inyilingki, Warren Creek and Mt. Liebig were established in 1978. Mt. Liebig has become the largest of all the camps established since then and has developed into a small resource centre servicing a cluster of outstations nearby. Ili Ili was established in 1979 when people from the now defunct camp at Unapuna (Mt. Larrie) moved to this location. New Bore was established in 1981 and the most recent camp, Warampi, (Three Mile) was established in 1982 .

Population

Among the 12 camps we visited only Mt. Liebig, New Bore, Warampi and Alkipi were occupied at the time of our visit. The greatest number of people were at Mt. Liebig although the number fluctuated greatly while we were there. When we first arrived most people had just left for a meeting at the Granites, north of Yuendumu and there were only a few old ladies, children and many dogs in camp. The following day everyone returned and the camp then seemed to be crawling with people. A few days later a truck-load of men from Yuendumu arrived on their way to Docker River on business and when they left a truck load of Mt. Liebig men went with them. People from Ilpili and Warren Creek were also camped at Mt. Liebig following deaths at those camps. Mt. Liebig also serves as a small resource centre and when the store is open people come from New Bore, Kungkayunti and Inyilingki. Such movements made it difficult to determine the population of Mt. Liebig, but we estimated a core population of between 40 to 50 people. There was a large group of children at this camp as well as young, middle aged and elderly people.

The second largest group of people were camped at Warampi. This group appeared to have a core population of about 20 people but when we were there an additional 20 or so people were in camp from Mt. Allen. Apparently 
these two groups have close family ties and there is constant movement between them. There were about 15 people at New Bore. When we arrived at this camp the people had just returned from hunting goannas and half of these then went on to Papunya. At Alkipi there were only five people in camp - one middle aged man, three middle aged women and one old woman. A well known man, Nosepeg Tjupurula usually lives at this camp, but is currently living at $\mathrm{Tj}$ inki near Kintore. He is a Pintupi man and said he was planning to move back to 'proper' Pintupi country. It is possible that other people from this camp will also move west when he goes. This was the only camp at which there were no children.

Four of the camps we visited were empty at the time of our visit, but were obviously being used regularly. At Inyilingki, for example, the camp fires were still smoking and we were told the people were out hunting. We saw the Inyilingki mob later at Mt. Liebig and on the road to Kintore. Kungkayunti was unoccupied when we arrived but these people returned to their camp that evening. There was nobody at Ulumparru or Blackwater although both camps still appeared to be in use. Both camps are close to Papunya and the people from these apparently spent much of their time at Papunya. These outstations tend to be used as weekenders. Ulumparru appeared to be the least used of the two and we were told that the owner rarely goes there. The people from Blackwater apparently have 'mobs of kids' who go to school at Papunya and the wife of the owner works as a cleaner at the school.

There was nobody living at Ili Ili, Warren Creek, Ilpili or Five Mile. warren Creek had been abandoned since the 1983/84 wet season following the death of an old woman. Ilpili had also been vacant for about one and a half years following a death. Ili Ili and Five Mile appeared not to have been occupied for several months. Both camps have a recent history of instability and there is nothing to suggest this pattern will change in the future.

Stability

The camps which are regarded by Europeans as stable in the Luritja Homelands include Mt. Liebig, New Bore, Inyilingki, Kungkayunti and Warampi. Our impressions confirmed this. Historically however, these and other camps such as Blackwater and Ulumparru have experienced considerable population fluctuations (Table 4.3). Blackwater was originally established with 45 people, but was vacated in 1979, following continuing problems with the natural water supply. The camp was redeveloped in 1983, but as indicated in the previous section, the people spend a lot of their time in Papunya. Ulumparru had a very auspicious beginning. There were originally 60 people and the camp was described as 'very cohesive' (DAA 76/12(1):67). Problems with the natural water supply again caused problems and the original site had to be abandoned.

Similar histories are recorded for Alkipi, Five Mile and Kungkayunti (Table 4.3). By 1979, Alkipi had a population of 100 people, but following a death the camp remained vacant for three years. Aspects of the development of Kungkayunti are well recorded and need not be retold here (see Moyle, 1979; Kimber, 1982; Morice 1978). It is sufficient to say that this camp originally contained about 100 people, but with the establishment of Kintore and Ilpili, most of these people left. The camp is now in a new location and is only used by a few families. Five Mile was originally occupied consistently, but this has also changed over the last few years. The people at Five Mile apparently have a drinking problem and outstation life has been disrupted by some serious drink related incidents. 


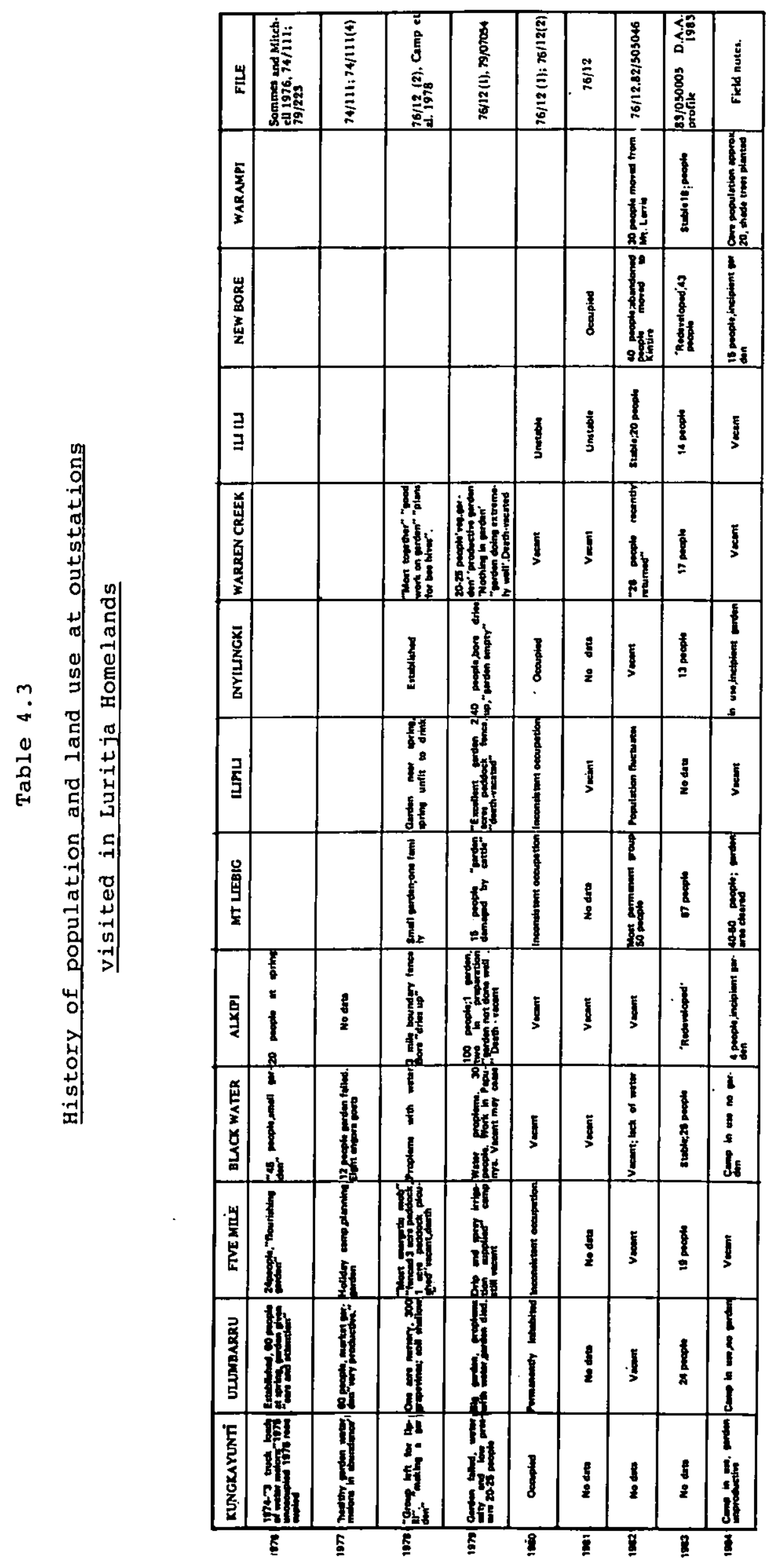


Three other camps we visited had also been abandoned for a long time. These were Ili Ili, Warren Creek and Ilpili. Warren Creek, when originally established, was described as 'stable and cohesive' but was vacated for two years following a death in 1979. The camp was re-established in 1982 and remained stable until early 1984 when there was another death. The people are now living at Mt. Liebig, but will no doubt return to Warren Creek in a few years.

Ilpili was also vacated following a death in early 1983 (the date may have been earlier than this as the most recent graffiti at the camp was written in 1982). The Ilpili mob said they would return soon; when a grader was organized to clear the scrub in the camp. We are inclined to be sceptical of this as the people here have a long history of inconsistent occupation. Ilpili is also a very convenient water stop for people travelling between Kintore and Papunya and the Aborigines implied that this was the camp's primary function. I was told that the camp at Ili Ili had 'never been permanent'. When we were there, the owner was in Alice Springs. He did return to Papunya, but only visited Ili Ili for one day during our visit. Prior to that, the camp did not look as if it had been occupied for months. We suspect the population using the camps at Ili Ili, Five Mile and Ilpili will remain transient in the future.

In the historical background given to this chapter, it was apparent that much of the instability characteristic of Luritja outstations was the result of the movement of Pintupi people west towards Kintore. The impact of the Kintore movement has already been discussed sufficiently in this report, so before leaving this section, brief reference should be made to other causes of instability in the Luritja Homelands movement.

The availability of water is one of the nagging problems of outstation development in Central Australia. Central Australia is very marginal country and it is not possible for sedentary populations to be supported by the ephemeral water supplies in that region. This did not happen in the past and is therefore unlikely to occur in the future. Even herds of cattle are not expected to live off natural water supplies in creeks, rock holes and clay pans. Thus to ensure permanent occupation of camps, permanent supplies of drinkable water must be obtained. The seasonal drying of natural waters has been a constant problem at the Luritja outstations in the past. Now all the outstations are serviced by bores or hand pumps and the availability of water should cease to be such a problem to those living on outstations.

With regard to deaths, it is apparent that camps are usually vacated for one and a half to two years following a death. This is the traditional period of mourning and Europeans should understand that such periods of absenteeism will always occur while Aboriginal people adhere to their traditional beliefs and practices. Because of this custom camps in the Luritja Homelands, and in other regions which are culturally related to the Western Desert Aboriginal groups, will be vacated for long periods after deaths among close family. These absences should not be confused by Europeans with a lack of commitment by Aboriginal people to their camps, but seen as a commendably uncompromised adherence to traditions by Aboriginal people.

There are also other causes for temporary absences from camps which may not be understood by Europeans. For example, Aborigines in this area have a tendency to be superstitious and may therefore move from camps because of unusual environmental occurrences (such as unusually heavy 
rains, unusual cloud patterns) or because of unpleasant dreams which arouse fearful superstitions seen as premonitions of the future. The Aborigines also have a constant dread of sorcery and gudidja men (sorcerers) and we were told that part of the reason Unapuna was vacated was the presence of gudidja footprints. There were also more obvious reasons for people being away from camp, such as a need to fulfil ceremonial and social obligations at different places or to escape punishment for social and religious misdemeanours. People from outstations will also stay at Papunya for long periods in order to help sort out problems or fights which other family members may be involved in.

Alcohol is also a disruptive influence on life at some outstations. The people at Ili Ili, Ilpili, Five Mile and Black Water were described as a 'mob of pisspots' and these camps are sometimes used as drinking stops by Aborigines so as to keep out of sight of the Papunya police. Aborigines see alcohol as a problem. They say camp life is disturbed by alcohol related fights and say that people from some outstations spend time away from camps on binges and use community vehicles to get grog.

Another factor which gives the appearance of outstation instability is the many temporary absences from camps when people are away doing things, such as hunting, visiting, taking people places, delivering food, getting videos and going to church or sport. This may mean that people may be away from camps for up to three days out of every five, but again, this should not be interpreted as a lack of commitment on behalf of the Aborigines to their camps. We recall one Pintupi man visiting from Balgo telling us 'It's in us, I don't know why, I can't help it. I've just got to keep moving'. This does not mean Aborigines are instinctively hyper-active, just that they are still nomadic by culture. Accordingly, they will move from place to place, but will nevertheless always return to their proper place.

Today toyotas are an integral part of that mobility and people will travel widely when toyotas are available. Often Aboriginal wanderlust is suppressed for long periods by the absence of vehicles and when a usable vehicle turns up it usually gets a hammering and is overloaded with people making up for all the travelling they had not been doing. Thus it is not uncommon during the first few months after the arrival of a new vehicle for outstations to be virtually abandoned as people travel around. In one instance, for example, one new toyota clocked up $25,000 \mathrm{~km}$ in the first seven weeks of operation (DAA $76 / 2(2)$ ). Even in the two weeks we were in the Luritja Homelands we were constantly amazed at the amount of travelling people were doing. In that period, for example, we saw 'Liebig' people make an overnight trip to the Granites $(970 \mathrm{~km}$ return). We saw Yuendumu people at Mt. Liebig on their way to Docker River, via Rintore (1,300 km return), followed by people from Mt. Liebig making the same trip ( $900 \mathrm{~km}$ return). We saw people from Mt. Allen at Warampi and Warampi people going to Mt. Allen (two trips; $240 \mathrm{~km}$ return) and there was already a truck load of Warampi people at Docker River $(1060 \mathrm{~km}$ return). We also saw people from New Bore, Kungkayunti and Inyilingki at Mt. Liebig and saw people from Mt. Liebig and Inyilingki at Kintore. We also saw all people from all these camps, including Kintore and Haast Bluff at Papunya watching football during the weekend.

There is a feeling, particularly among Europeans that 'toyota dreaming' is behind much of the outstation development. The suspicion is that because people on outstations are eligible to receive a 90 per cent subsidy from ABTA funds for a toyota, some outstations are simply set up to get cheap toyotas. The view was put that if you can get a fully equipped 
long wheel based land cruiser for 1600 bucks, which is what you pay for a clapped out holden in town, you will go onto an outstation for a few month's. The view is understandable (and is certainly what some Europeans would do) and is reinforced in the eyes of some Europeans when toyotas arrive and people do spend much time in them travelling around the country. However, we believe this view is overly cynical as we have no evidence, and were given no evidence, of any outstation in the Luritja Homelands which had been set up specifically to obtain a cheap ABTA toyota.

One final point should also be made regarding instability on Luritja outstations. This goes back to the historical problem over land ownership. The outstations which now exist in the Luritja Homelands are mostly occupied by Luritja people. Most of the Pintupi people have moved to Kintore and further west. Nevertheless, there are still a few men owning outstations who are not Luritja and this may be a cause for instability in the outstation movement in the future. As already mentioned Nosepeg Tjupurula from Alkipi is a Pintupi man and plans to move permanently to pintupi country. This may mean that the rest of the people from this camp will move with him when he goes and the camp will become unoccupied. At present Alkipi is being run by a brother and is well maintained and gives the impression of permanency. Similar problems may also arise at other camps. At New Bore, for example, the owner is Pitjantjatjara and his wife is Pintupi. At Blackwater, the owner is also Pitjantjatjara and at Ilpili and Warampi the current camp bosses are only 'Kurdulungu', or managers of the land, rather than the actual landowners or 'Kurda' (see Palmer 1983; Myers 1976, 1982 for explanation of land ownership). Thus it is possible that these people may be pressured to move as Luritja people seek to gain greater control over their land or when younger men grow up and wish to take control of land which belonged to their fathers.

\section{Facilities}

\section{Houses}

All the camps we visited, except Kungkayunti, had at least two first stage or 'colourbond' houses (Plate 4.1). These houses are the same as those described in the Pintupi Homelands and more closely resemble tin sheds than houses. They cost about $\$ 4,000$ to erect and consist of a single room (about $3 \mathrm{~m} \times 3 \mathrm{~m}$ ) and have two verandahs which provide morning and afternoon shade. They seem popular and are well looked after. They are small, but can be extended, and provide effective although basic shelter and storage. None of the houses we saw had been vandalized or damaged - a situation that was very different from the condition of houses at papunya.

At Kungkayunti, accommodation consisted of one square shed (resembling a first.stage house without verandahs) and three humpies. Camps at Inyilingki, New Bore, Alkipi, Ili Ili, Ilpili and Five Mile had been provided with two first stage houses each. At Inyilingki, the frames for another three houses were laid on the ground and this, in addition to one tin shed and two windbreaks seemed sufficient for the three families living there. At New Bore additional accommodation was provided by four tin humpies, three windbreaks, one tent and two sun shelters for the summer (Plate 4.2). There was also a small caravan at New Bore but this was only used by. the local priest when he visited on Sunday. At Alkipi there were an additional two house frames ready for construction and the Aborigines had constructed one summer shade shelter. 


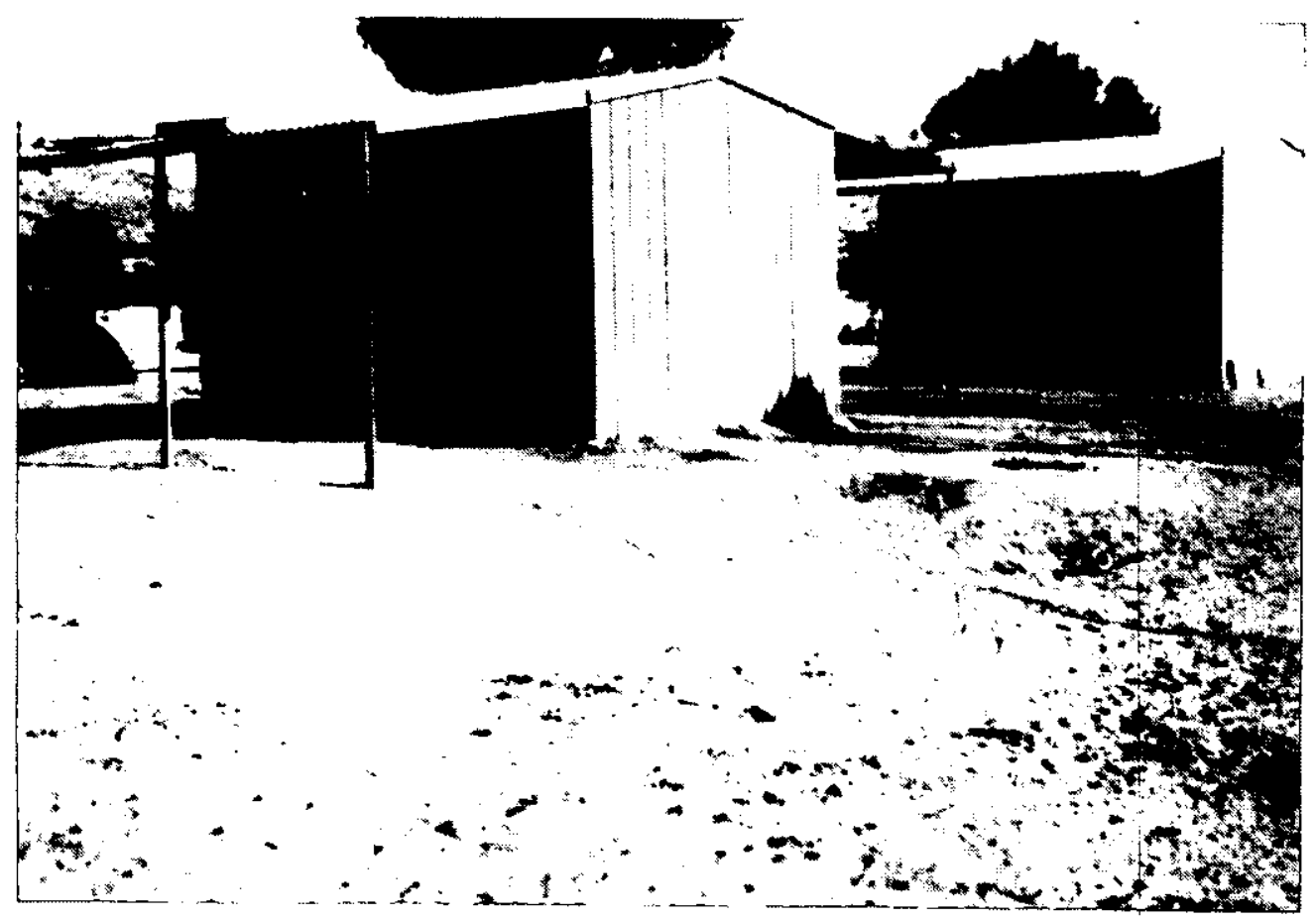

Plate 4.1 First stage - or 'Colourbond' houses at Alkipi

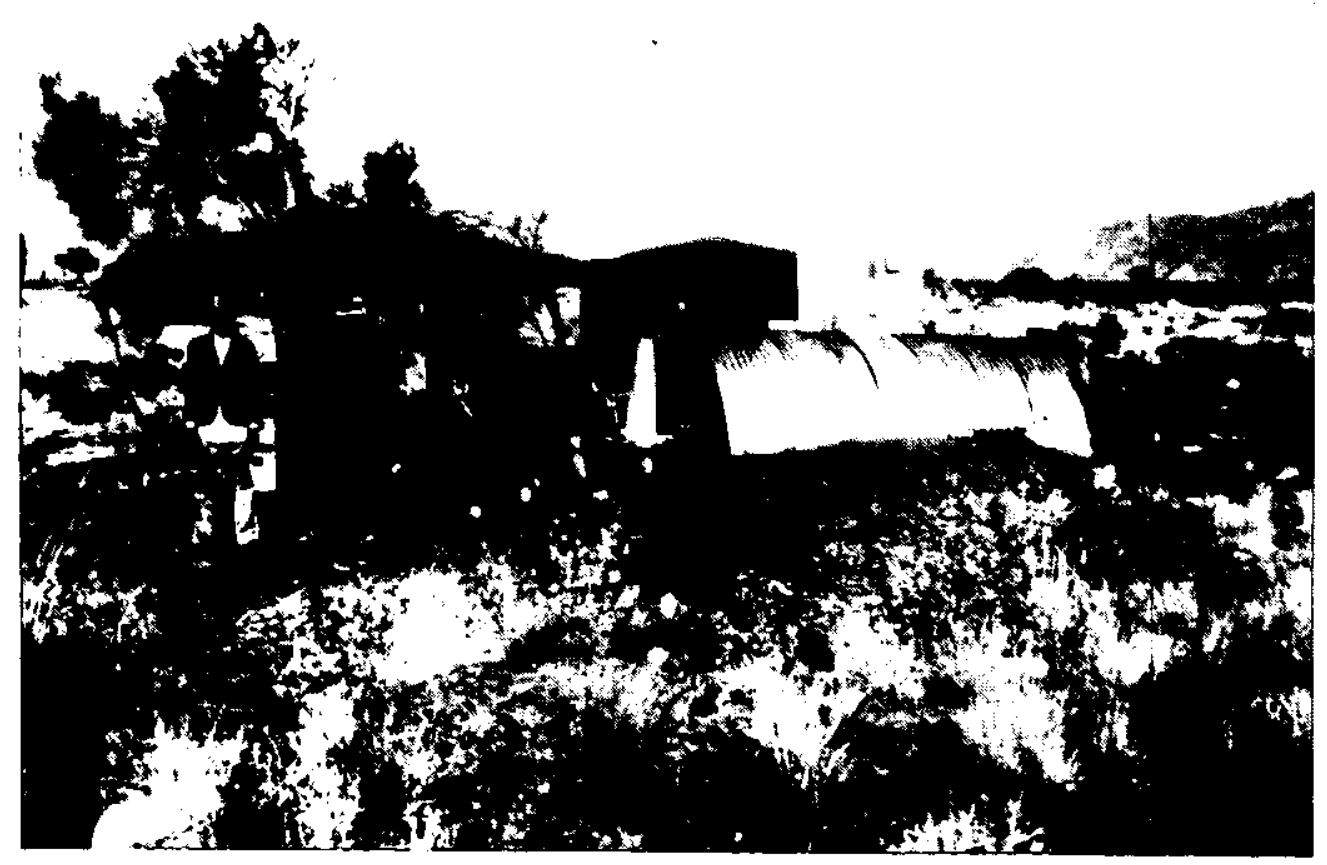

Plate 4.2 Part of the camp at New Bore 
In addition to the first stage houses at Ili Ili accommodation also consisted of two galvanized iron windbreaks, two tin sheds (one of these had curtains in the window) and one sun shelter. There were also frames for two more first stage houses there. At Ilipili there was an additional tin shed used originally for the radio and stores, and four tin humpies made from the upturned halves of water tanks.

Each of the camps at Ulumparru, Black Water and Warampi had three first stage houses. In addition Black Water also had one sun shelter and two shelters made from upturned sections of water tanks bolted to rectangular wooden frames. Similar 'bolted' humpies were at Ulumparru and here there was also a shed and a large tent. The accommodation at Warampi consisted of eight humpies and two sun shelters. There were also two frames laid for additional houses. Each of the houses already constructed at Warampi had a large room attached to one verandah. This had been done by the Aborigines with pieces of wood and corrugated iron scavenged from Papunya. The Warampi houses also had concrete floors. Concrete floors were very popular and were wanted by everybody in outstations around Papunya and Yuendumu. Concrete floors keep the inside of houses dry during the wet season and keep out mice, snakes and scorpions during the hot months before rain. Concrete floors were in the process of being laid at Ulumparru.

At Mt. Liebig there were six first stage houses and six humpies. One of the houses had been extended to 'second stage' by the attachment of another first stage house. Frames for another two houses had been laid; although one of these was to be used as a school. Most of the humpies and windbreaks at Mt. Liebig were occupied by people from Ilpili and Warren Creek and these were located on the western side of the camp.

Mt. Liebig was the only place where people were actually living inside or underneath the verandahs of the houses supplied. At the other camps the houses were acting as store rooms, only being used for shelter during wet season rains. People preferred to camp out of doors, around fires, during the cooler months and under the shade of thatched shelters during the hot summer months.

With the exception of Kungkayunti and New Bore we felt that the existing and in-progress houses met the needs of the number of people using the Luritja outstations at the time of our visit. The people at Warampi were the only ones who specifically indicated a need for more houses.

\section{Water}

All of the camps we visited had been equipped with bores or hand pumps tapping underground supplies of water (Plate 4.3). Originally this was not the case and people at Ulumbarru, Black Water, Alkipi and Ilpili were plagued by contaminated and/or irregular supplies of water from natural springs and soaks. Now, the water supply at five camps is provided by hand pumps (New Bore, Warampi, Ulumbarru, Black Water, Ili.Ili) and six camps have windmills and tanks (Warren Creek, Mt. Liebig, Five Mile, Ilpili, Alkipi and Kungkayunti). One camp, Inyilingki is equipped with a nissan diesel pump.

At the five camps with hand pumps the people complained about the lack of windmills and reticulation. The people at Ulumparru said they do not spend much time at that camp because they are 'waiting for a windmill'. At New bore, Warampi and Ili Ili, the hand pumps are a long way $(0.5-1 \mathrm{~km})$ from the camps. Water is usually transported from the pumps in empty flour 


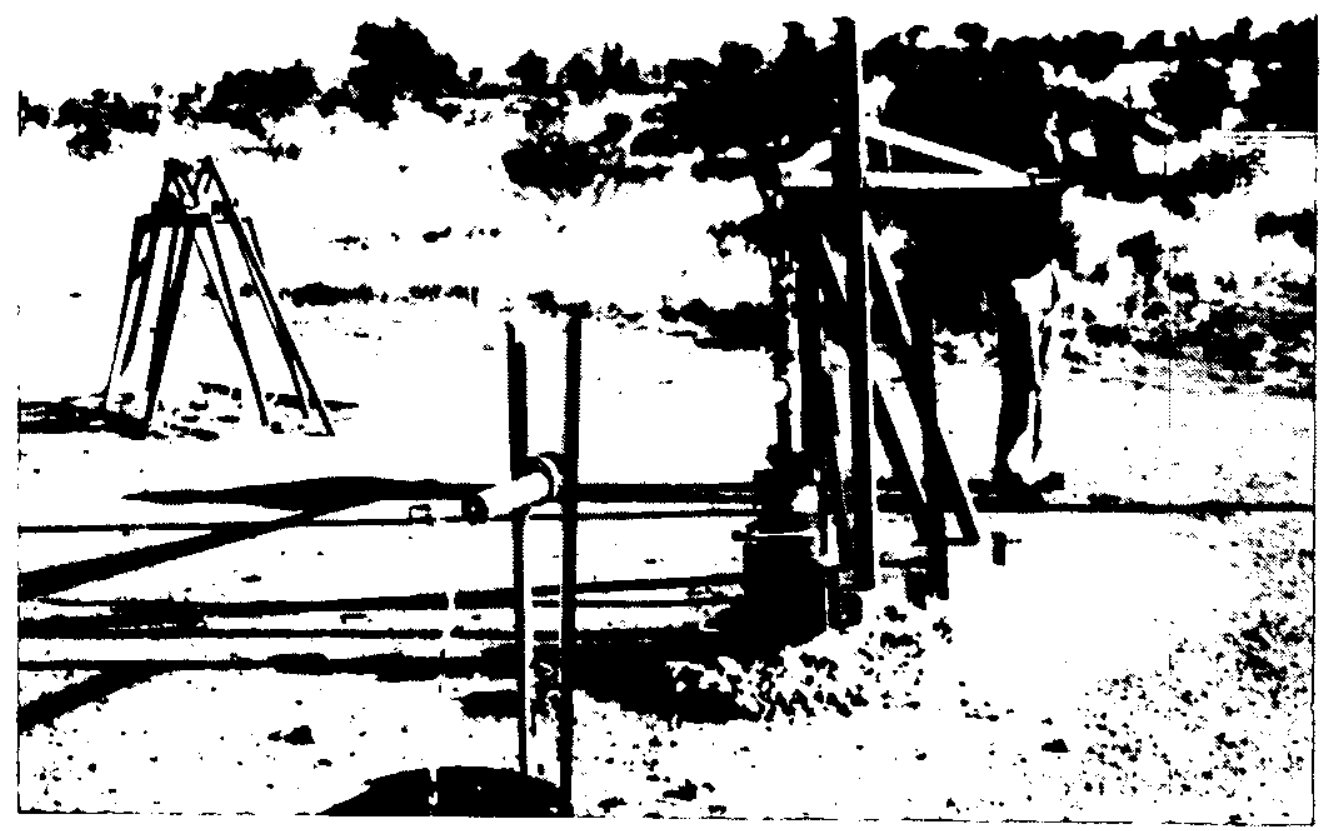

Plate 4.3 Hand pump at New Bore

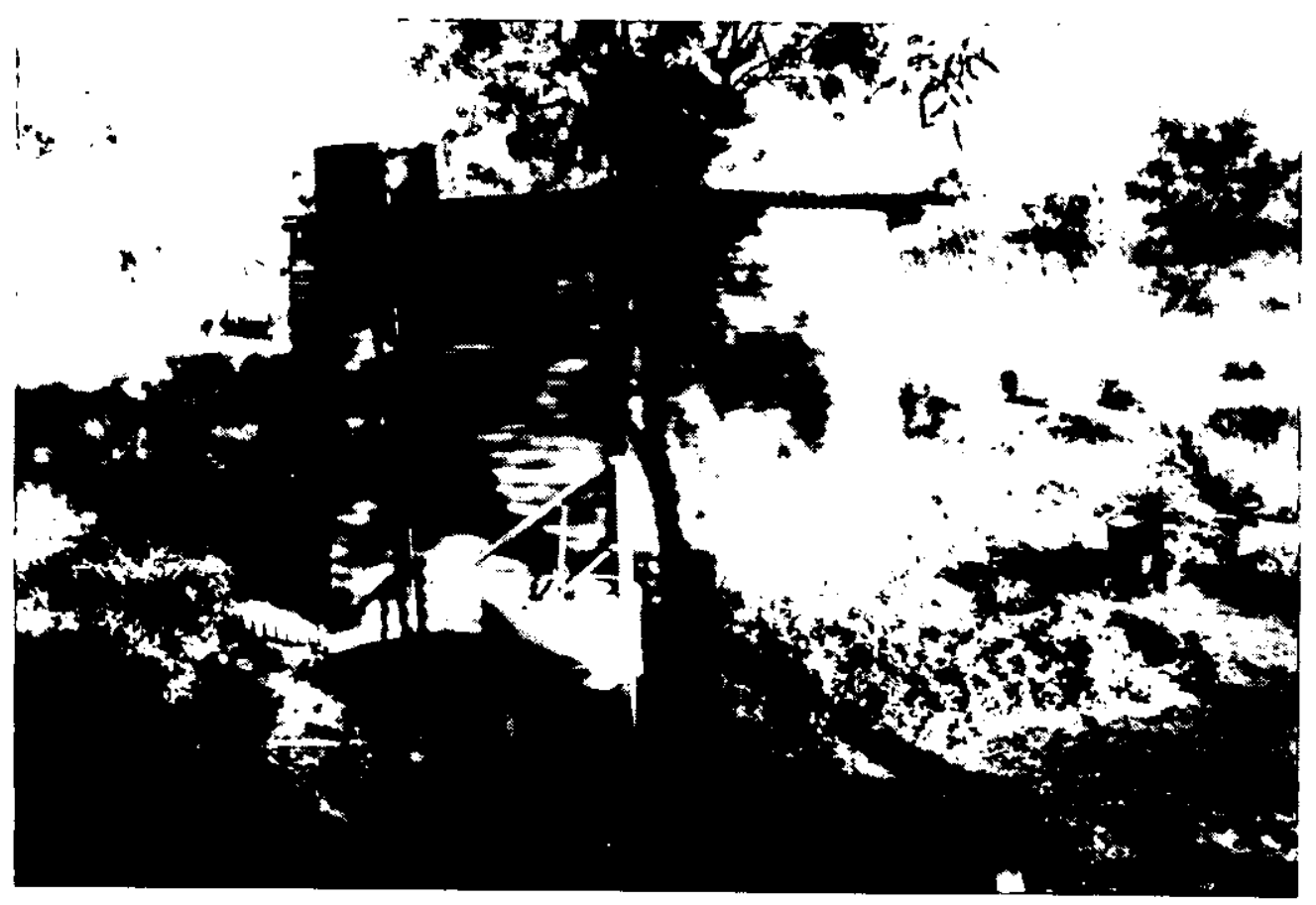

Plate 4.4 Shower facilities at Mt Liebig (note camp wasining machine in foreground) 
drums. These weigh $20 \mathrm{~kg}$ when full of water and, if no transport is available, are difficult to carry over those distances. Water transportation becomes a major chore during the summer when temperatures in the shade get close to 50 degrees Celsius and the ground temperatures are sweltering. At this time people need to drink between 20 to 30 litres of water a day and water cartage becomes a major problem.

The people at Warampi complained that getting water from the hand pump was too much work and said it made their arms ache. It is likely that this would be a problem for some of the older people as filling a flour drum with water does require some effort. Hand pumps, however, have the important advantage of being more or less maintenance free and relatively inexpensive to provide.

All the camps next to bores, except Inyilingki, received an adequate quantity of water. Here the bore continually dried up after several hours pumping and had to be left for about half a day while the underground supply restocked. Warren Creek, Mt. Liebig, and Five Mile were located on old cattle bores around which stockyards, fences and water troughs were still visible. Kungkayunti was originally located on a cattle bore (Browns Bore), but is now located $1 \mathrm{~km}$ to the south.

Water is reticulated to most camps. At Five Mile there are three taps near the camp but none provided any water. As far as we could gather the windmill there has been defective for a while. There are two taps at Mt. Liebig. One is located near the bore and used to wash vehicles. The other is located over $100 \mathrm{~m}$ from the nearest house at camp. This tap is so far away from camp because the water pressure, supplied by a small tank set at ground level, is insufficient to push the water all the way to the camp. This water supply is obviously inadequate for the population at Mt. Liebig and while we were there we observed a constant stream of women moving to and from the tap to get water. An additional problem is that the tap leaked and spillage collected in a large boggy pool around the tap. This pool has a very unhygenic smell and must be a snake hazard during the spring and summer. The Aborigines complained to us about the pool and had thrown all sorts of junk (car radiators, camp ovens, hub caps) into it, so they would not get their feet wet when getting water. This just added to the messy stagnation of the pool.

At Ilpili and Alkipi the water is piped over a distance of one to one and a half kilometres to each camp. When we were at Ilpili the windmill was spraying water from its base. The water tank and windmill had not been disconnected at Kungkayunti and the water tank was over-flowing.

Clearly, windmills provide the most convenient way of supplying water to outstations and one can understand the desire of the Aborigines to obtain them. Nevertheless, windmills are expensive and require servicing and maintenance. . At present, the Aborigines are not skilled and do not seem all that keen to maintain them and there are not enough European service staff to do the job. No one, for example, had done anything about the water problems at Kungkayunti, Mt. Liebig or Five Mile and the Aborigines had not even dug a trench to drain the spillage away from the tap at Mt. Liebig or disconnected the windmill and tank at Kungkayunti to stop the tank over flowing. It is in the light of such problems that the provision of hand pumps, despite their unpopularity, seems sensible.

There is also an additional problem associated with bores the reticulation of water in black PVC pipes. These pipes are

caused by invariably 
Figure 4.2

Water quality of camps in Luritja Homelands

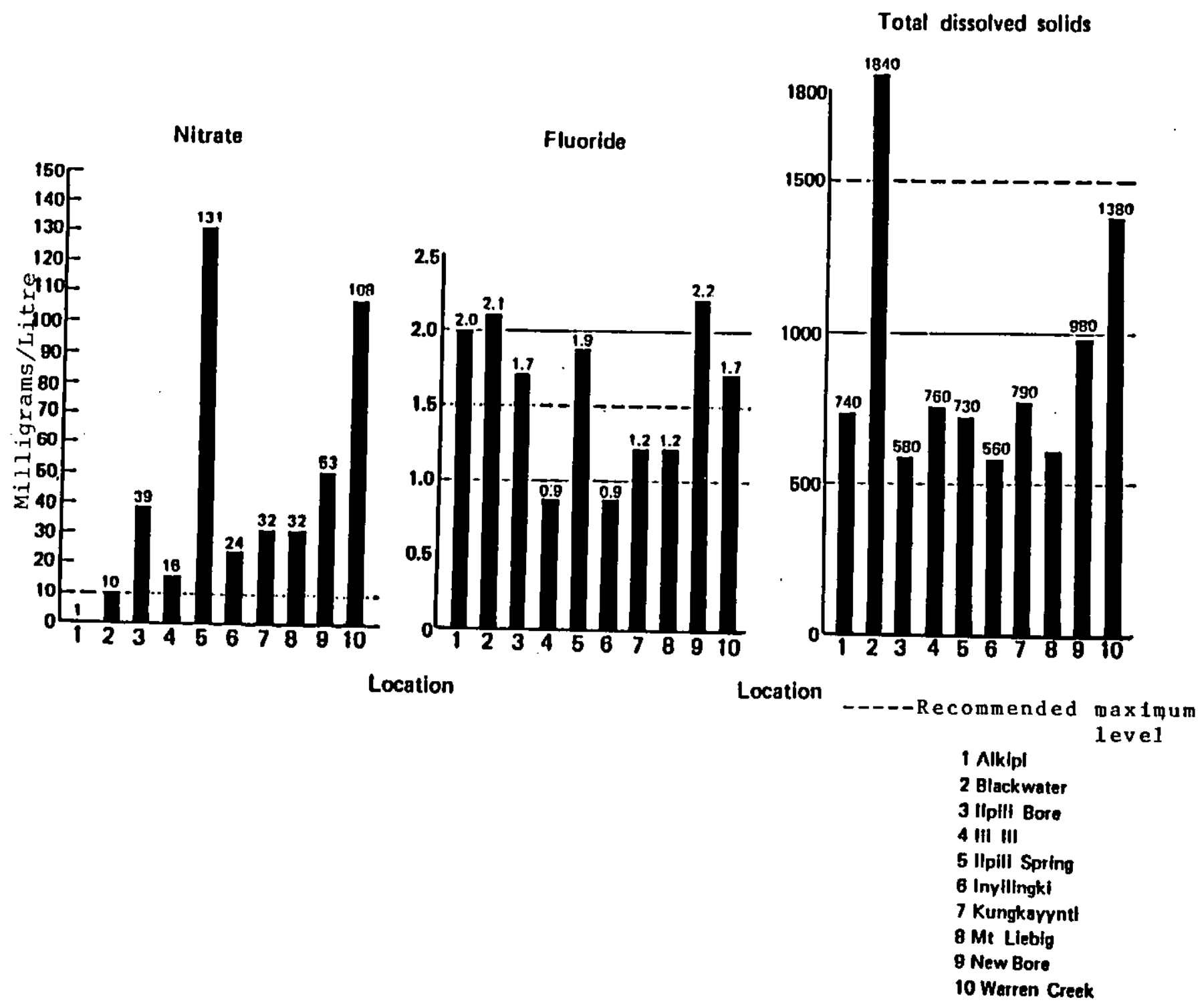


laid close to the surface and thus get very hot. This is particularly obvious at Ilpili and Alkipi where stretches of pipe are also exposed above ground and the water was unpleasantly warm. The water at these camps must get dreadfully hot in summer. It would be a simple matter to use white or grey pipes instead. At Alkipi and Warren Creek we also noted that the pipe is even exposed across roads. Consequently, the pipes were being driven over and were squashed and cracked. One cannot expect plastic pipes to last long if they are constantly run over. Another danger to exposed plastic pipes is fire. Aborigines continually burn the country around camps and the danger of melting exposed pipes presents a constant threat to camp water supplies. Children also present something of a problem when water pipes are exposed. They are inclined to bouts of vandalizing and sometimes punch holes in the pipes. Obviously these problems could be solved if the water pipes were placed several feet underground.

One of the major and final problems with the water supply at Luritja outstations is that people at all the camps are drinking water which contains unacceptably high levels of chemicals (Fig. 4.2). We could not get water quality data for Ulumbarru or Five Mile but among the remaining ten we noted specifically that Blackwater had excessive concentrations of iron, dissolved solids and fluoride; Alkipi had excessive fluoride; Ilpili was high in fluoride (the water from Ilpili spring was high in fluoride and nitrate) and the water at both New Bore and Warren Creek were high in nitrate and fluoride.

\section{Communications}

As far as we could ascertain, radios have been provided to all camps in the Luritja Homelands, except possibly Alkipi, Kungkayunti and Warren creek. At these three camps, there are no radios when we visited and we could find no evidence in DAA files that radios had been supplied. Despite the provision of radios to the remaining nine camps, none of the radios at any of these are operational at the time of our visit. There are in fact no signs of radios at all at Inyilingki, Ili Ili, Warampi, Five Mile and Black water. Nor are there any radios at Ilpili or Ulumbarru although the aerials, solar batteries and radio sheds are still in existence. At Mt. Liebig and New bore the radios are broken. One of the major causes of damage to radios, apart from physical abuse, is wet season rains. Radios are usually fixed near their aerials and protected by waterproof metal containers. If the lids are left of these containers during rains, water gets in and ruins the radios. This had happened at Mt. Liebig and New Bore.

In 1978 all the Luritja outstations obtained ABTA toyotas (DAA file May 1980). These are no longer in use and the camps we visited were using a variety of private vehicles and some new ABTA toyotas and dyna trucks. The people at Mt. Liebig, Ilpili and Warampi had relatively new dyna trucks. Eive Mile had also received a dyna truck last year but had apparently destroyed it after only nine weeks. The people at warren creek and Kungkayunti both have community toyotas. The Kungkayunti toyota is new and there are wrecks of four well used toyotas at their camp. There are no community vehicles at New Bore, Inyilinki; Ili Ili, Ulumbarru, Black Water or Alkipi and at these camps people used private vehicles for transport.

As already mentioned the appearance of new toyotas at Luritja outstations seems to cause consternation among some Europeans at Papunya. Toyotas are generally identified as being indirectly responsible for outstation instability and problems with alcohol. There seems to be some justification for this concern as people do tend to travel a lot when they 
have a new toyota. The suggestion was made to us that it would be better to supply outstations with tractors and trailers rather than toyotas. Then people could still go hunting and gathering, could collect firewood and transport sick people to Papunya. The rationale was that tractors were slower and less comfortable and would thus reduce the frequency of grog runs and the general mobility of people. It was argued that people could still go to 'business meetings' using private cars. There may be some merit in this suggestion, although a DAA official pointed out that tractors had been tried before and were unsuccessful. Grog runs still occurred, tractors got flat tyres and were forever breaking down. On one occasion, a tractor was taken from an outstation near Mt. Liebig to Glen Helen for a load of alcohol. This is a return journey of $340 \mathrm{~km}$ !

\section{Other Facilities}

All the camps we visited contain an assortment of hand tools (axes, crowbars, shovels, rakes) and hardware (particularly tarpaulins and tents). There is also a wide range of other miscellaneous bits and pieces. For example, there is a rain water tank at New Bore, although the tap is missing and the tank was unusable. Both Inyilingki and Mt. Liebig have manually operated washing troughs. Inyilingki also has a video machine. This is shared with Mt. Liebig which has a generator. Thursday nights are video nights at Mt. Liebig and video tapes were supplied by the outstation co-ordinator from Papunya. There is also a galvanized iron showering shed at Mt. Liebig (Plate 4.4). This unit is very antiquated and is inadequate for the needs of the 50 odd locals. Water has to be pumped into a small copper unit on top of the showering bay but is not heated and is agonizingly cold during the winter. Kungkayunti had the biggest collection of miscellaneous equipment. This gear was housed in a large tin shed and consists of a generator, large axe grinding stone, extension cords, two chainsaws and an electric drill.

\section{Services}

The essential services provided to camps in the Luritja Homelands depended very much on their location. People living at camps within $20 \mathrm{~km}$ of Papunya (Ili Ili, Alkipi, Black Water, Ulumbarru, Five Mile, Warampi) have to commute to Papunya for education, health care and stores. Camps further west (New Bore, Ilpili, Warren Creek, Inyilingki) looked towards Mt. Liebig and Kintore for the supply of essential services. The outstation co-ordinator living at Papunya provided an important and popular service by delivering social security and pension cheques to New Bore, Mt. Liebig, Warren Creek and Inyilingki. He also supplies and opened a small store at Mt. Liebig. This seems to be a key factor encouraging and stabilizing outstation development in that area. The store opens on Mondays, Wednesdays and. some sundays. It is well looked after and the surrounding grounds are kept clean by the Aborigines. The outstation co-ordinator runs a system of credit at the store in which debts accumulated over each fortnight are repaid each pay day. This system seems to work well and is popular. When the store is open people commuted from Warren Creek, New Bore and Inyilingki to get food. People living at Kungakayunti also commute regular$1 y$, but this outstation is also served by Haast Bluff.

There is also a small school at Mt. Liebig. This is run by a school teacher from Papunya who camps at Mt. Liebig from Tuesday till Friday each week. Children from Mt. Liebig and neighbouring camps attend the school. According to DAA profiles for 1983 there are 58 children in this area between the ages of five and 15. Despite the efforts of the teacher the 
facilities are grossly inadequate for that number of children. The school is very rustic and was built by the locals. It consists of an open ended galvanized iron shack set amongst four mulga trees. These provide welcome shade during the summer. School equipment consisted of a few old chairs and tables and a steel cabinet in which crayons, pencils and stationery are kept. A small football oval had been graded next to the school and a first stage house is being constructed as a much needed new school building.

There is no health service at Mt. Liebig and a sister visits this and neighbouring camps from Papunya every Thursday. There are air strips close to Ilpili and Kungkayunti, but these are overgrown and, as the Aborigines explained, are 'finished now'.

\section{Topography}

\section{$\underline{\text { Landscape }}$ and Land Use}

The landscape of the Luritja Homelands provides some of the most magnificent scenery in Central Australia. The backbone of the region consists of the Belt Range near Papunya and the Amunurunga Range near Mt. Liebig (Amunurunga is a corruption of the Aboriginal name for these mountains, Yamundurrngu). These are rugged mountains rising $1000 \mathrm{~m}$ from the surrounding plains. They are made of granite, gniess and schist and are scarred with large cliffs and steep gorge like valleys. South of Mt. Liebig are large hills of dissected sandstone. These end abruptly in a large escarpment overlooking a broad flat sandplain extending south towards the Idirriki Range near Haast Bluff. Hugging the base of these mountains are low foot hills, broad valleys and flood plains. Relatively well developed but ephemeral creeks weave through the valleys and fade into braided channels in the flood plains and sand plains.

Much of the eastern part of the Luritja Homelands consists of small, closely packed, parallel sand dunes. These run east-west from Mt. Liebig to Ilpili. Gently undulating sand plains constitute the greatest proportion of the northern and southern portions of the Luritja Homelands and a band of salt lakes forms an approximate northern boundary between the Luritja and Walpiri Homelands.

Most of the outstations are located in the foot hills and flood plains surrounding the mountainous country of the Luritja Homelands (Table 4.4) Kungkayunti, however, is an outlier, located south of the mountains nestled in close, irregularly patterned sand dunes. Ili Ili is also located in sandy country amongst small dunes north of Mt. Larrie. Warampi and Five Mile are set among patches of mulga and low rocky granite hills. With the exception of New Bore, the remaining camps are all situated next to creeks. New Bore is located on an imperceptible sandy rise among small creek channels and alluvial fans which flood during heavy wet season rains.

\section{Climate}

The nearest comparable climatic data we have for the Luritja Homelands comes from Yuendumu, $100 \mathrm{~km}$ to the north (see Chapter 6). The climatic picture there is characterised by hot wet summers and cold dry winters. The Luritja Homelands, like the Pintupi Homelands are slightly further south than this area and thus receive more winter rain and occasional frosts and less summer rainfall from tropical lows. The mountainous country in the Luritja Homelands also catches more cloud and thus greater precipitation than the Pintupi Homelands. The increased altitude also decreases average 


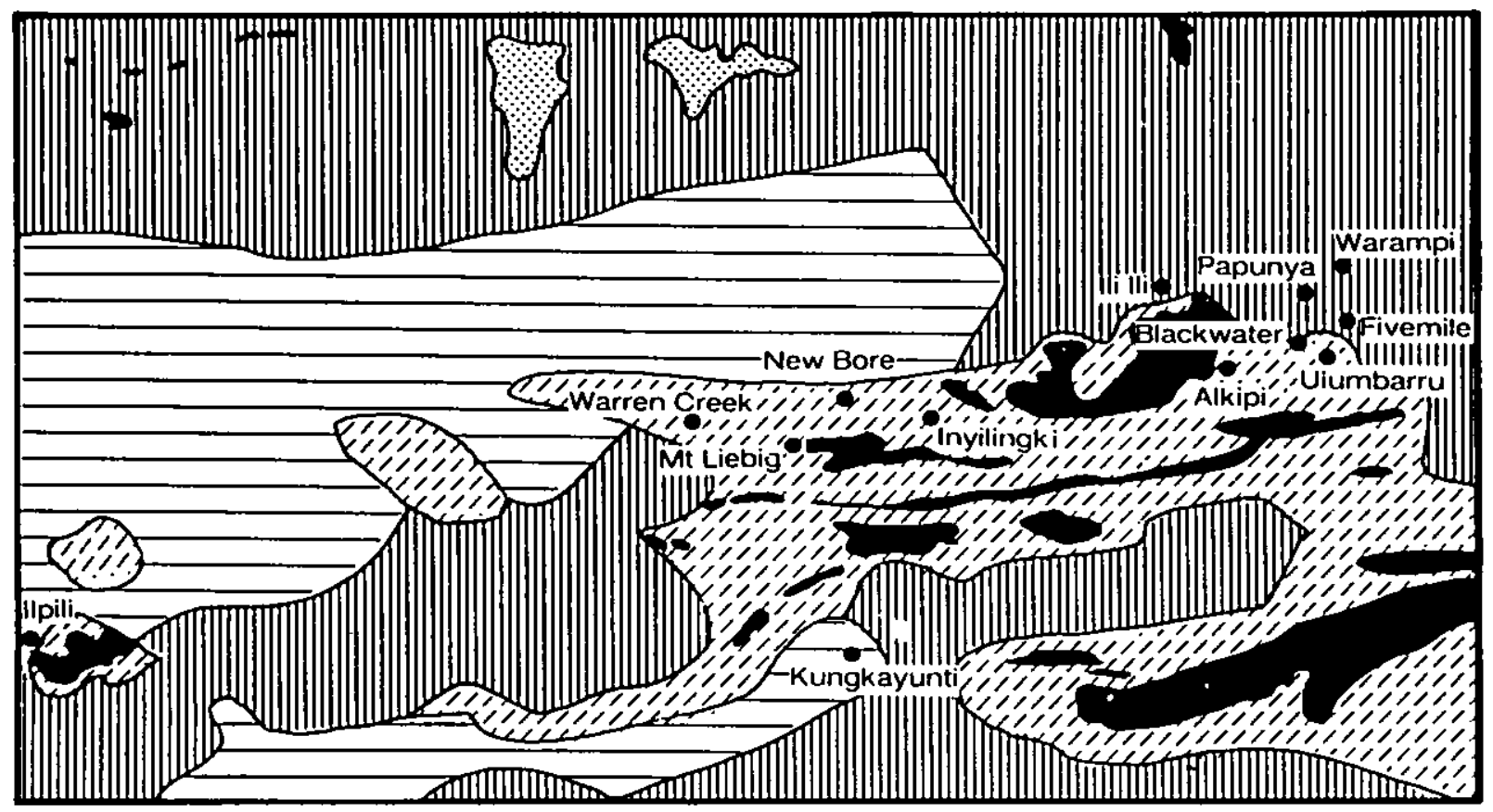

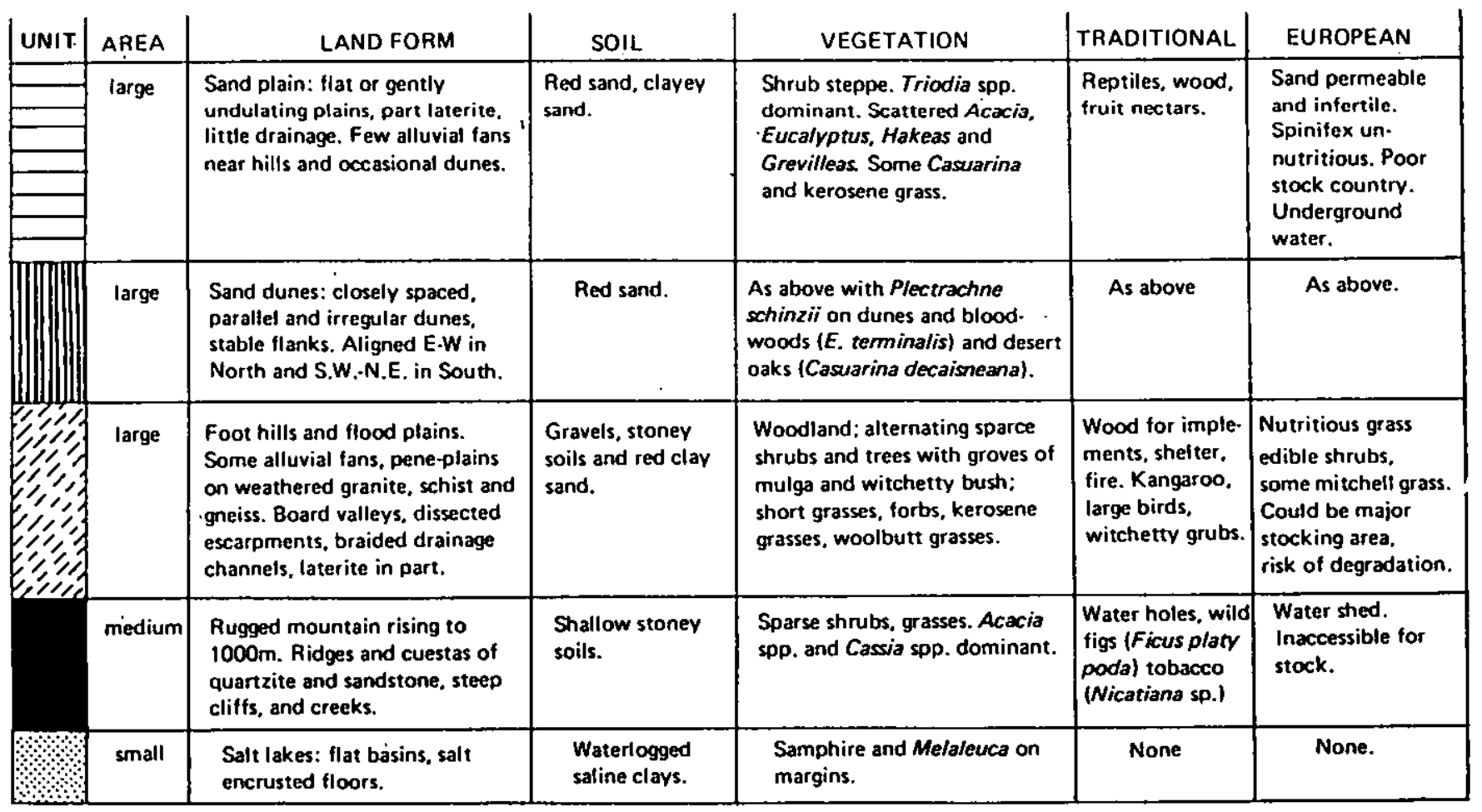


temperatures. The average rainfall for the Luritja Homelands varies between 200-230 mm/year and the temperature varies between a summer maximum of 30-36 degrees Celsius; and minimum of 18-24 degrees Celsius, whereas the winter maximum varies between 18-24 degrees Celsius and the minimum between 0-6 degrees Celsius (Bureau of Meteorology 1974).

\section{Vegetation}

The plant communities surrounding most of the camps in the flood plains and foothills are dominated by mulga, gidgee, witchetty bush, scattered bloodwoods, and small shrubs (Cassia spp. Gossypium sturtianum, G. australe, styloblasium spathulatum). The ground cover usually consists of short grasses, kerosene grass, woolybutt, and a variety of herbaceous plants and daisies generally referred to as forbs. The density and composition of these woodland communities varies somewhat although mulga is always the most common tree present. At Mt. Liebig, for example, there are large groves of mulga while at Ilpili short grasses dominated and trees and shrubs were scarce.

As mentioned already most of the camps located on the flood plain were adjacent to creeks. The dominant plant species along the creek lines were red gums, bean trees, and coolibahs. At Warren Creek these trees were thick and unusually high for a desert environment.

Camps in the sand plains are surrounded by desert oak, grevilleas, hakeas, bloodwoods and mallees. Hard spinifex is the dominant species of spinifex on the plains, but was replaced by a beautiful feathery topped species (Plectrachne schinzii) on deeper sand and dunes. Some camps such as Warampi, Five Mile, Ili Ili and New Bore are located on the interface between the flood plains and sand plains and in such locations mixed communities of sand and flood plain vegetation co-existed. On rocky ground there is very little vegetation. Shrubs (Acacia spp. and Cassia spp.) are scarce and grasses predominated. Wild figs, and tobacco grow in shady crevices where there is some soil.

\section{Plants of Economic Importance}

The bulk of the Luritja camps are located in mulga country and these plains are not rich in vegetable foods. The most economically important plant used in this environment is mulga. This species exudes a popular malt-like 'sap' and is an important fire wood and raw material for making wooden implements. Dead mulga is an excellent slow burning fuel and the green wood is the best material available for making shields, boomerangs, clubs and spear throwers. Another economically important plant species that grows in this type of country is the witchetty bush. These plants are most common in the Warren Creek, Mt. Liebig side of the Luritja Homelands and contain abundant, easily obtained nutritious grubs in their root.

The micro habitats associated with the ephemeral creeks which run through the foot hill sand flood plains also provide a substantial source of traditional food. One of the most important is the bush onion, which is gathered from sandy creek beds. Tubers, bush plums and silky pears are also gathered from creek banks. Coolibah trees provide an additional supply of edible grubs and bean trees supply a valuable softwood used for making wooden implements.

Two species of bush tomatoes (Solanum chippendalei, S. centrale) are actively collected in the Luritja Homelands. These species tend to colonise 
freshly burnt or disturbed ground and are often abundant at camps and along roadsides as well as wild in the sandplains and flood plains. The three main plant foods eaten on the sandplains include bush tomatoes, honeysuckle, and coconut apples from the desert bloodwood. Unfortunately the Luritja Homelands are about $100 \mathrm{~km}$ too far south to enjoy access to rich patches of bush potato like those found in the Walpiri Homelands. We noted extensive areas of kurrajong near Kungkayunti and dogwood near Ilpili. The seeds of both were once important traditional foods but are only eaten occasionally these days.

The mountainous country in the Luritja Homelands is the poorest in vegetable resources. Here there are only three plants of importance. These include the wild fig, native tobacco and the flower heads of a small tuftlike shrub (Mollugo molluginea) which are mixed with ochre and used for ceremonial decoration.

Animals

Although the Luritja Homelands are not generously endowed with vegetable foods the extensive foothills and flood plains are very good country for hunting. The availability of nutritious feed, waterholes and shade make the region most favourable for both cattle and game. Kangaroos are relatively abundant and we saw numerous fresh tracks and droppings and always saw kangaroos when driving off the main road. One afternoon driving to Putarti Springs we saw 16 kangaroos in three herds. Flood plains are usually popular locations for bush turkeys and emus although the Aborigines said these birds were not very abundant in the region. Men said emus and turkeys were more numerous further west and it is possible that the Aborigines have shot out much of the local populations. We did not see any emus and only saw two sets of tracks left by bush turkeys. We have already mentioned the importance of witchetty grubs as a food source in the flood plains and in addition the Aborigines avidly collect honey ants in this country. Honey ants are collected towards the end of the wet season and we were told they are particularly common near Warampi.

The rocky country in the Luritja Homelands is also good country for hunting. The most commonly hunted species are euros, rock wallabies, echidnas and giant perenties. There are literally 'big mobs' of euros in the hills in this region. In one instance, for example, at putardi Spring, we counted six euros on one large rocky hillside. If this density holds true for each hillside in the region then the local population must be quite substantial.

Reptiles are the most important animals collected from the sandplains and dunes. The most important species are goannas, blue tongue lizards and pythons.

Camps and Traditional Land Use

In a fashion similar to the Kintore Homelands movement the Luritja movement has brought back to the land the traditional enthusiasm for 'looking after the country' by burning. Thus since the consolidation of the Luritja outstation movement large areas have been reburnt to clear the ground for goanna hunting, to attract game and to stimulate the growth of fruit growing shrubs. This was in evidence as we travelled through the region and constantly passed through areas of ground that had been burnt in the last three to four years. This was particularly noticeable near warampi and in the region west of New Bore, Mt. Liebig and Kungkayunti. 
Figure $4.3 a$ and $b$

Fire patterns in the Luritja Homelands 1979,1983

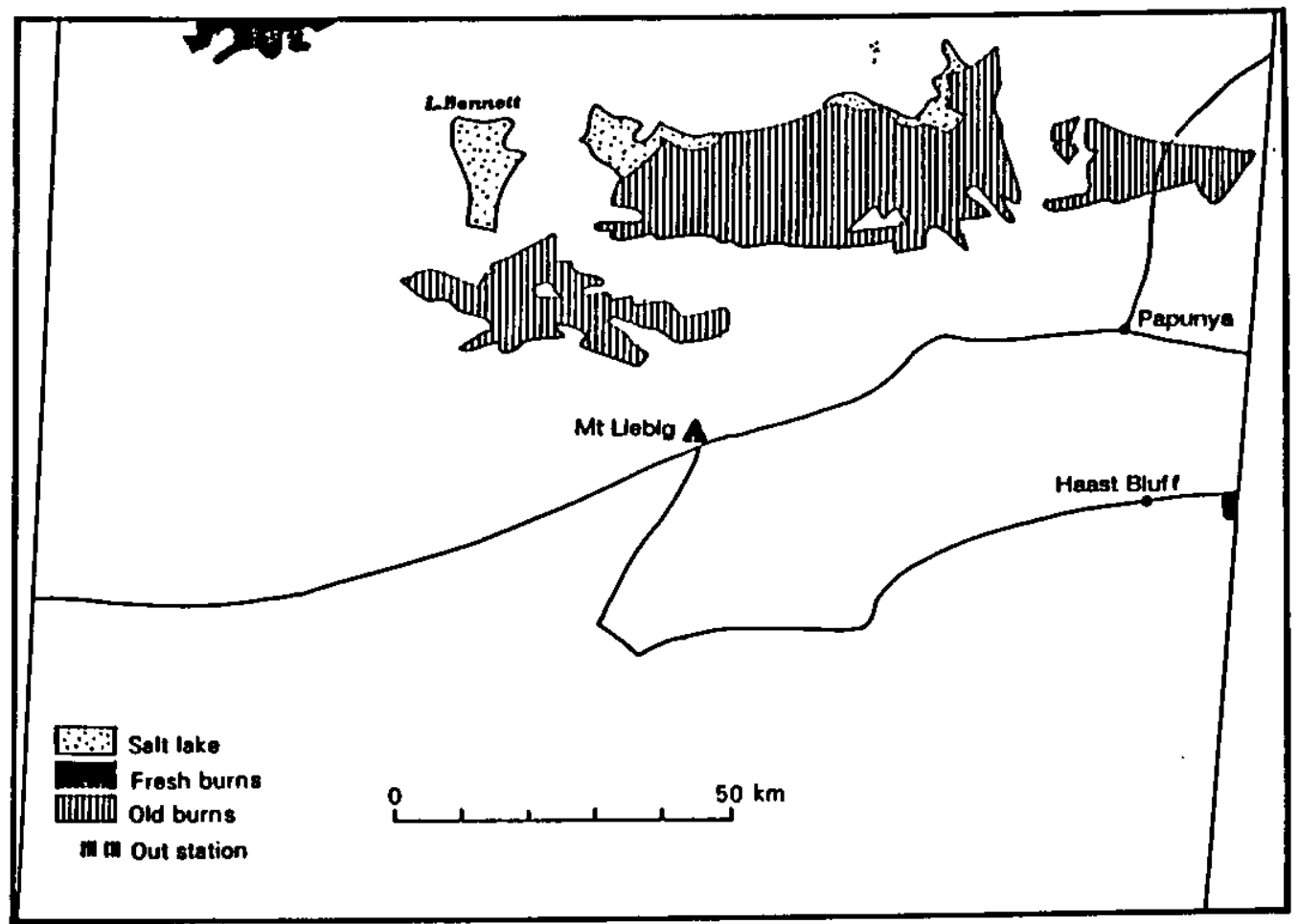

Figure $4.3 a$ 1979

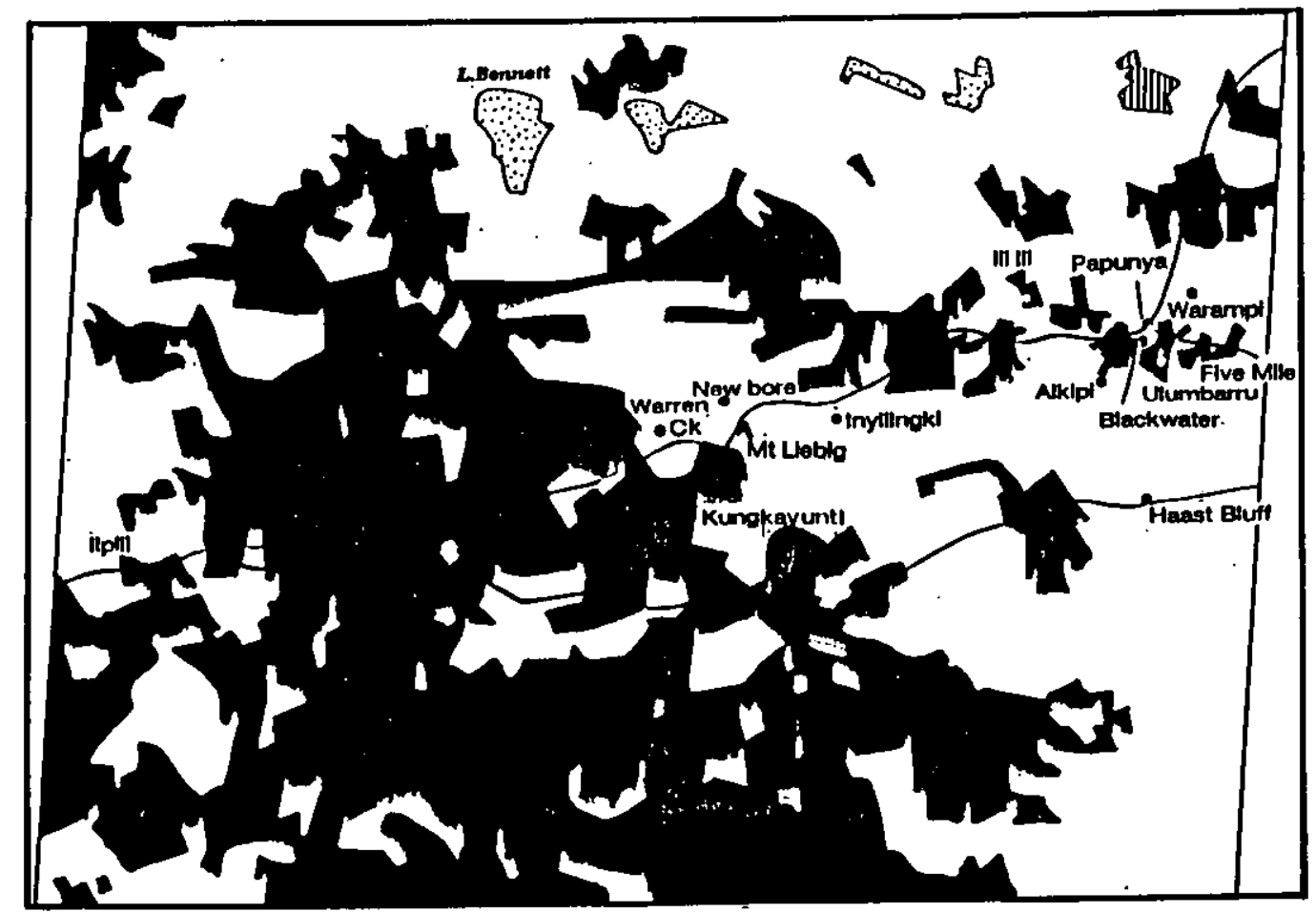

Figure $4.3 b$ 1983 
The extent of fires associated with the outstation movement is highlighted most dramatically in Figures $4.3 \mathrm{a}$ and $4.3 \mathrm{~b}$. These figures have been drawn from sequential satellite imagery of the homelands over the last five years. Fig. $4.3 a$ represents the extent of the fire pattern in the Luritja Homelands in 1979 whereas Fig. 4.3b displays the extent of the fire pattern in 1983. Clearly the absence of fire prior to 1980, compared with the enormous stretches of burnt ground near outstations and roads in 1983 is strong evidence for the extensive use of traditional land management practices in the Luritja Homelands now the outstation movement has established itself.

As far as bush foods were concerned we felt they were probably less important economically to the people in the Luritja Homelands than in the Kintore Homelands. This may seem strange as people from both homelands displayed the same enthusiasm for bush tucker and supplies of large game were in fact far more plentiful in the Luritja Homelands. Unlike the Pintupi people however, the people in the Luritja camps had much better access to store food. For example, six of the 12 outstations (Warampi, Five Mile, Black Water, Alkipi, Ulumparru, Ili Ili) were within $20 \mathrm{~km}$ from Papunya. In fact you could walk from Ulumparru, Black Water and Warampi to Papunya in less than 30 minutes. With the exception of Ilpili and, to a lesser extent, Kungkayunti, the remaining camps had easy access to the Mt. Liebig store. This opened two to three days each week and provided fresh and tinned meat, flour, sugar, tea, fruit juices and miscellaneous vegetables and cereals. Thus, unlike the people occupying the Kintore Homelands, those in the Luritja Homelands had regular access to European food. Consequently, when money was available European food was easy to obtain and tended to be the dominant food eaten. The people at camps near Mt. Liebig would get food on credit and thus the availability of money placed even less restraints on the quantity of European food consumed at these camps.

Nevertheless, there is still a. strong penchant for traditional food; particularly those foods which do not require too much effort to obtain. As indicated in the previous section, there is quite a variety of bush tucker that falls into that category and consequently sizeable quantities of bush food are gathered at particular times of year. Food that are always collected when in season include wild figs, wild plums, silky pears, bush tomatoes, coconut apples, tubers, nectars, reptiles, large marsupials, birds, witchetty grubs and honey ants. At Mt. Liebig the people eat at least one kangaroo a week. At New Bore there are sufficient quantities of emu feathers, turkey feathers, goanna skins, bush tomatoes and coconut apples as well as roasting pits for turkey and kangaroo to indicate that bush foods are still an integral part of the outstation larder. While we were at New Bore, a group of women returned from a goanna gathering trip. We also saw turkey feathers at Ili Ili and kangaroo pits at all the other camps. When we went to Ilpili the men were loaded with bags and billies to collect bush tomatoes growing from seeds dispersed from fruit eaten at the camp previously (Plate 4.5). The crop at Ilpili was very rich and in an hour we had collected enough to feed six adults and five children and fill a large billy and a school bag to take back to Mt. Liebig. Similar fortuitous gardens growing from the seeds spilt from consumed fruit were growing at New Bore and Five Mile.

In a study of outstation life at Kungkayunti in the mid 1970s Morice (1978) indicated bush foods constituted 50 per cent of the diet at that camp. Our impressions were that this figure is higher than it is today and generally felt that bush foods contributed about 20 per cent, perhaps a third of the food eaten at outstations. This is difficult to ascertain 


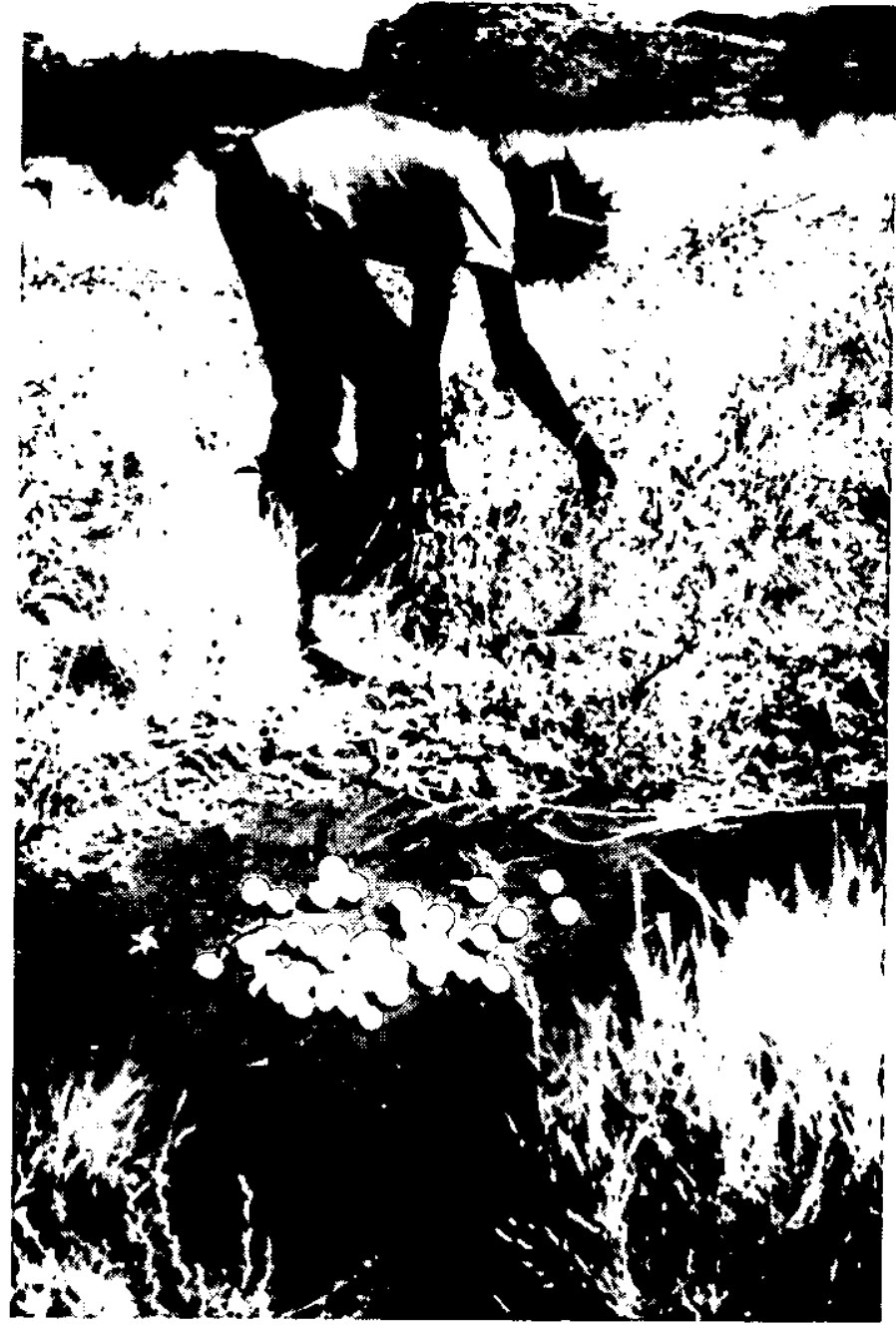

Plate 4.5

collecting bush tomatoes at Ilpil1

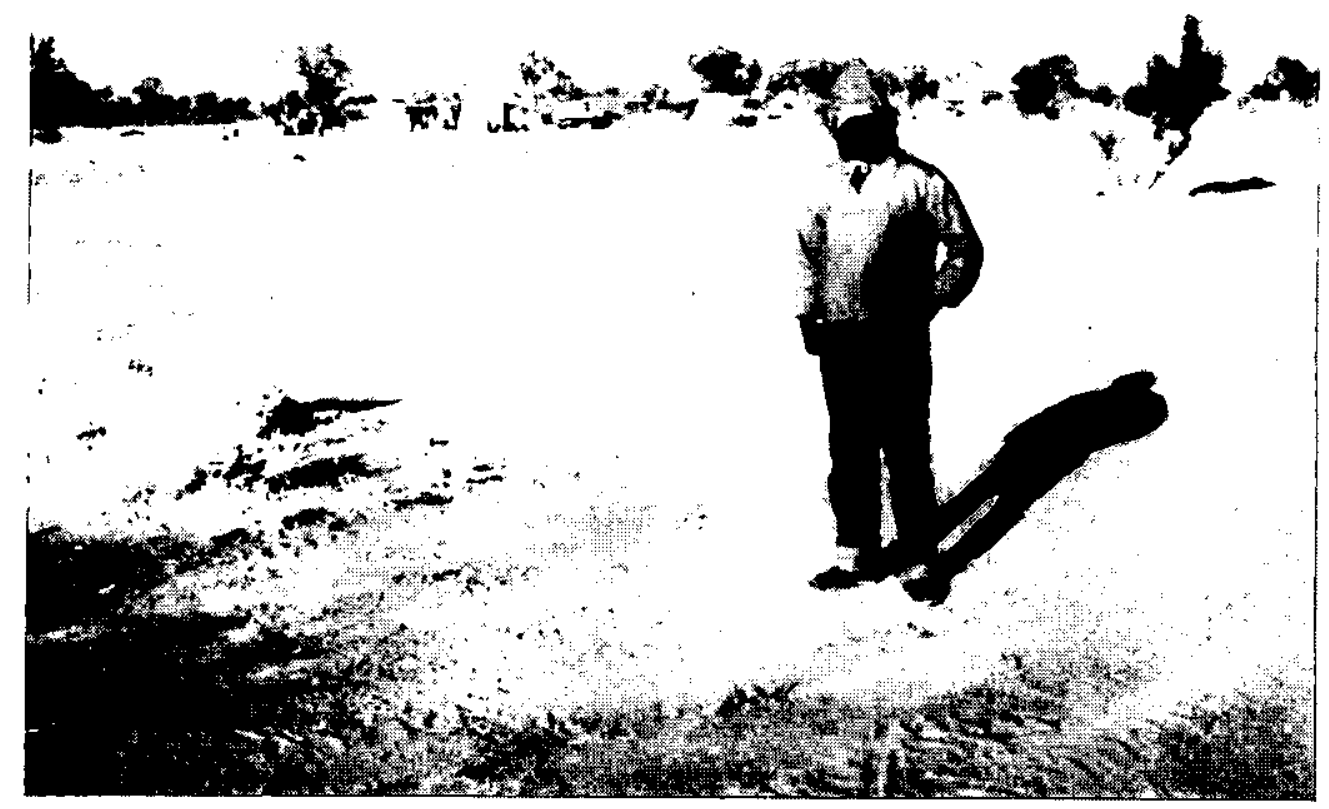

P1ate 4.6 Large area cleared for garden at Mt. Lieb1g 
without long term study but we feel it would not overstate the situation to suggest bush foods account for at least one out of every five meals eaten by Aborigines living in the Luritja Homelands. This quantity obviously fluctuates seasonally and is probably significantly lower during the wet season when game is dispersed, fruits are out of season and travel is difficult. The availability of store food is also very important. The consumption of bush tucker is generally inversely proportional to the availability of store food and, as indicated, less bush food is eaten when store tucker is in camp.

Traditional materials are still used extensively for building, for domestic fires and the construction of shelters at outstations. Local supplies of hakea, desert oak, gidgee, mulga and local shrubs are frequently used in the construction of summer shelters, windbreaks, fences and sheds. These same hardwoods are also important for firewood. Mulga is of course the most popular firewood and the Luritja camps are fortunate to be surrounded by so much of it. Nevertheless, the Aborigines, here and elsewhere are very economical in their use of this wood for burning. Fires are generally arranged to burn into the wind, so they burn slowly, and are usually only made of two or three pieces of wood. One trunk of mulga and a few small branches are usually sufficient for a family for at least 36 hours continual use. Wood from the many wirey acacia shrubs are used extensively for cooking. These burn quickly and provide a lot of coals which are useful for cooking damper and cooking large game in earth ovens.

Mulga is also a very important material for making wooden implements and is used for making spear throwers, shields, punishment spears, clubs, boomerangs and sacred boards. This wood as well as other traditional materials like spinifex resin and kangaroo sinews are still used in preferance to any European substitutes for constructing wooden implements. The light softwood from local bean trees is also important for making coolimans, softwood shields and artefacts for sale (see below). Traditional hunting spears are used extensively in the rejuvenating ceremonial life of the Aborigines in this region and are obtained from the Pintupi people near Jupiter Well.

Gardens

European Land Use

The Luritja Aborigines have a fascinating history of involvement in horticultural enterprises (see Table 4.3). This history appears to have been flavoured by lingering European concepts of progress and the virtues of industry imported from early settlement and mission days as well as a good deal of wishful thinking among contemporary Europeans. In retrospect one sees the gardening exercise of the Luritja Homelands as ill-conceived, based largely on non-Aboriginal initiatives (Nathan and Japanangka, 1983:126). The program seems to have been sparked by a few early successes drawn into a general enthusiasm in which Europeans failed to see what is obvious today; that Aboriginal men in this part of Australia are not interested in becoming peasant farmers.

No doubt the early successes were seen as very auspicious. In 1975, for example, the garden at Kungkayunti produced three truckloads of watermelons for sale (Sommes and Mitchell 1976-8). From another outstation $\$ 200$ worth of watermelons were sold to Alice Springs in 1977 (DAA file 74/111:61). During the late 1970s 10 outstations that are still in existence today had gardens. Among those camps Mt. Liebig and Black Water had small gardens; Alkipi had a garden and another two gardens in 
preparation; Ilpili had 'an excellent garden' near the spring which contained two dozen fruit trees; Warren Creek had a 'productive garden'; Five Mile had a 'flourishing garden' and an additional three acre paddock fenced and a one acre paddock ploughed. Ulumparru had a garden in which 300 grape vines were growing. The garden at Kungkayunti was growing butternut pumpkins and watermelons 'in abundance' and had a second garden growing watermelons and silverbeet. The outstations, generally, were described as growing sweet corn, melon, cabbage, figs, mulberries, grapes and oranges. Some outstations were apparently investigating goat farming, camel herding, poultry and bee keeping (Wilkinson, 1981; DAA files 74/111, 79/07054, 79/12, 76/12(i), 76/12(2); Sommes and Mitchell 1976).

Thus, it was not surprising following the years of Aboriginal repression and economic dependency that the possibility of Aboriginal economic and social independence which presented themselves through horticultural endeavour were greeted with enthusiasm. Such enthusiasm had tangible results. The Luritja outstations were supplied with 2,000 trees for gardens, windbreaks, shade and dust control. One thousand metres of drip irrigation were supplied and 500 citrus trees were bought. In addition there were plans to supply Warren Creek outstation with horses and bee hives and to supply Five Mile with 'fertilizer, seeds, irrigation for growing fodder, feed for hens and green manure crops as well as vegetables' (DAA $76 / 12(2))$. An $\$ 80,000$ nursery and orchard were established at Papunya.

One can imagine the optimism generated by such reports and not surprisingly this filtered through to the press. In 1979 Aboriginal News wrote of the outstation movement:

Gardening is the 'in' thing. Enthusiasm for gardening has been so marked that an outstation agricultural development officer... has been appointed to advise on suitable crops, water reticulation methods, fencing improvements, forestry stands and to help procure suitable cuttings, seeds and plants.

The most popular crops are sweet corn, melons, cabbages, figs, mulberries, grapes and oranges.

Some outstations with better resources, such as Five Mile, have been able to be more adventurous, also growing green manure and crops and hen feed (Robin, 1978:20).

Such reports in fact obscured the true situation, and we suspect, along with other wishful thinking, led the Aborigines down a path they never intended to follow. Ironicaliy the Aborigines seem, somehow, to have received the blame for the failure of the programme. The true situation at Five Mile in 1979, for the sake of the record, was that a one acre paddock had been ploughed, but never planted. There was a death soon after and the people left the outstation for a long period. The garden remained bare and there were even plans to remove the unused drip lines and taps to another camp (DAA file 76/12:92).

Uncritical acceptance of the supposed horticultural development in the Papunya region also seems to have filtered through official reports. In relation to Warren creek in 1979, for example, one finds the extraordinary situation where in four different reports that year the people were described as having a 'productive garden', a 'fine garden', a garden which 
was 'doing extremely well' and yet was also reported as having 'nothing in the garden' (DAA files 76/12, 79/07054).

Despite the general optimism for the horticultural development in the Luritja Homelands, some apparently unheeded advice was received to the contrary. For example, in 1977 the community adviser at Papunya warned that:

Melons, cantelopes, beans, silverbeet and pumpkins were seen but most looked very dry and untended ... I cannot help but be a little sceptical about the motives behind the market garden development and their success; in anybody's terms! With the exception of the melons, the crops are rarely to the taste of the grower and the possibility for export severely limited. The dedication required to operate a garden seems ill-fitting to Aboriginal life style and $I$ wonder if, in fact, they are a hang-over from old 'settlements' and cattle station days when they were deemed to be an essential part of setting up a settlement (DAA file 74/11l:60).

Little notice appeared to have been taken of such views at the time. Perhaps these opinions were seen as an unacceptably pessimistic expression of racism at a time when Europeans saw horticulture as the key to an acceptable and lasting form of Aboriginal 'self determination'. Whatever the case the truth of the warning is common knowledge today (see Nathan and Japanangka 1983:59) and productive horticulture is now non-existent in the Luritja Homelands. In 1984 the only signs of the old gardens at Black Water, Ilpili, Alkipi, Warren Creek, Five Mile, Ulumbarru and Mt. Liebig are a few fence posts and tangles of wire. All that is left of the 'excellent' garden at Ilpili is one fig tree hugging the edge of the spring.

In the wake of such failure one is led to ask why the horticultural programme failed. We were told many reasons. We were told the project was not inspired by Aborigines and thus they were not motivated to garden. We were told the Aborigines were lazy and spent too much time away from their camps. It also seems likely that the first gardens were the product of a few old men with a gardening habit developed through their contact with settlements and missions. Another possibility was that the Aborigines were gardening to appease white people over that initial period in which it was necessary to impress officials and thus ensure the funding necessary to establish and develop their camps. Perhaps a combination of these factors attributed to the failure of outstation gardens in the Luritja Homelands. If our interpretation of the history is correct, however, several other reasons should also be considered.

At Mt. Liebig for example, the garden was destroyed by cattle during a muster. At Black Water the garden failed because the ground was so salty. At Ulumparru the soil was very shallow and the water supply erratic. At Alkipi attempts were frustrated by an erratic water supply, and were then terminated by a death. At Ilpili, Warren Creek and Five Mile, the gardens were also abandoned because of deaths at those camps. At Kungkayunti the first gardens were abandoned when the Pintupi left for Ilpili and Kintore and the camp at Brown Bore was deserted. Thus, in addition to the reasons we can speculate on, one also sees the demise of the gardening enterprises in the Luritja Homelands brought about by the incompatibility of the sedentary lifestyle necessary for successful horticultural development and the mourning customs of the Luritja Aborigines and the extreme difficulties placed on desert farmers by the harsh and unforgiving desert environment. 
Today, with the exception of Mt. Liebig and Kungkayunti, one sees a very different form of agricultural development at the Luritja outstations. At Kungkayunti and Mt. Liebig, the horticultural developments are more like old style gardens. Kungkayunti's garden consists of a cleared and fenced area about $20 \mathrm{~m} \times 40 \mathrm{~m}$ in size. Grape vines, citrus trees and watermelons have been planted in the garden but all are dead except one citrus and one watermelon plant. The garden appears not to have been tended for a long time and is overgrown with prickles. At Mt. Liebig a huge area has been cleared ready for planting in the spring, but given the regions' market gardening history we are sceptical of the Aborigines' long term enthusiasm for such a large garden (Plate 4.6).

At other camps, rather than these typically large rectangular gardens (fenced, cleared and planted from side to side with neat lines of citrus trees, melon and vegetables) one can see a different approach to horticultural development. These new gardens strike us as the tentative beginning of an incipient form of agriculture suited to the environmental and cultural characteristics of the Luritja outstations. For example, at New Bore the people have planted a few bean trees and coolibahs collected from the local river for shade at the camp. They also planted a line of bamboo and some rock melons although we noticed that the coolibahs and most of the bamboo are dead. At Inyilingki the people have planted white cedar trees near taps as well as some climbing beans and watermelons along a $30 \mathrm{~m}$ plate chicken wire fence. This is intended to provide a windbreak and some food. At Alkipi seven year beans, watermelons and native bean trees have been planted. Even at Five Mile we noted one watermelon has been planted. At Ili Ili two rectangular patches about $1.5 \mathrm{~m} x 1 \mathrm{~m}$ in size have been cleared and planted, although whatever was planted was dead (Plate 4.7). At Warampi several white cedar trees have been planted and enclosed with chicken wire to protect them from vandalism by children.

Thus at camps today one sees some very elementary, but Aboriginal inspired attempts at horticulture and camp improvement. The question this raises is whether this is truly the beginnings of an Aboriginal initiated form of agricultural development or simply the last gasp of the agricultural failures of the last 10 years. We are inclined to see these local developments optimistically and believe that if given patient, experienced guidance (rather than European interference) these developments could be very productive for local Aboriginal use in the long term. At present these attempts indicate inexperience, and are largely unsuccessful. Plants are usually inadequately watered, placed in positions exposed to the sun and wind and are easily vandalised by children. Nevertheless, it seems to us that these little gardens and isolated plantings reflect an Aboriginal attempt to adapt European methods of horticulture to an Aboriginal lifestyle and the outstation environment. If encouraged, we think this development, in conjunction with the use of traditional resources, may sow the seeds for a lasting and uniquely Aboriginal form of horticultural practice providing substantial shade, shelter and food for Aborigines on outstations. We will develop this further in chapter 8.

Animals

The Luritja Homelands contain some of the best cattle country in Central Australia (see Perry 1960, 1962) and consequently there have been cattle interests in the area since the ration depot was first set up at Haast Bluff in 1941. The Government set up a cattle project at Haast Bluff in the early 1950s and sunk bores at Mt. Liebig, Warren Creek and Browns Bore. These cattle enterprises were not very successful and were only 


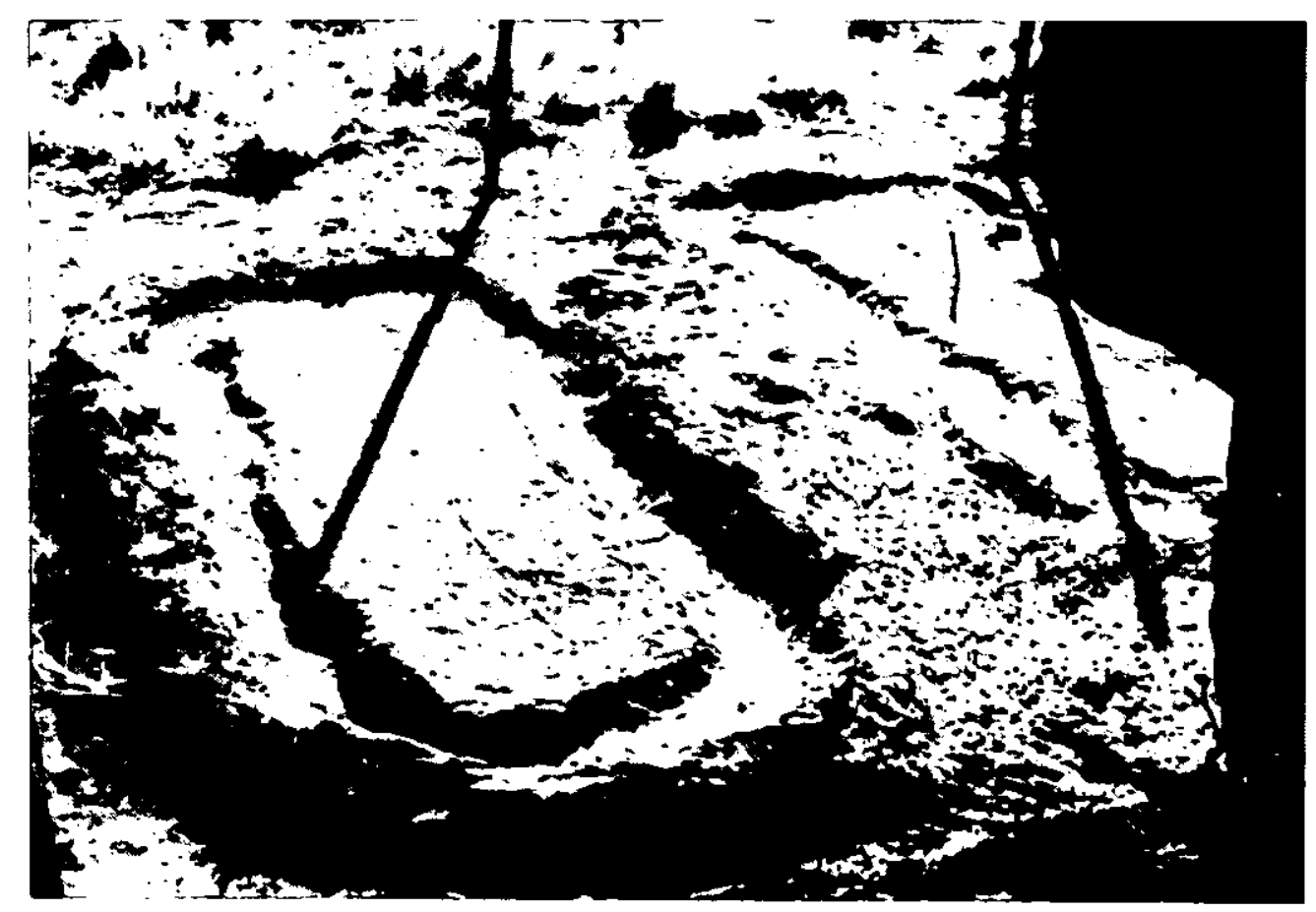

Plate 4.7 Small garden attempted at Ili Ili

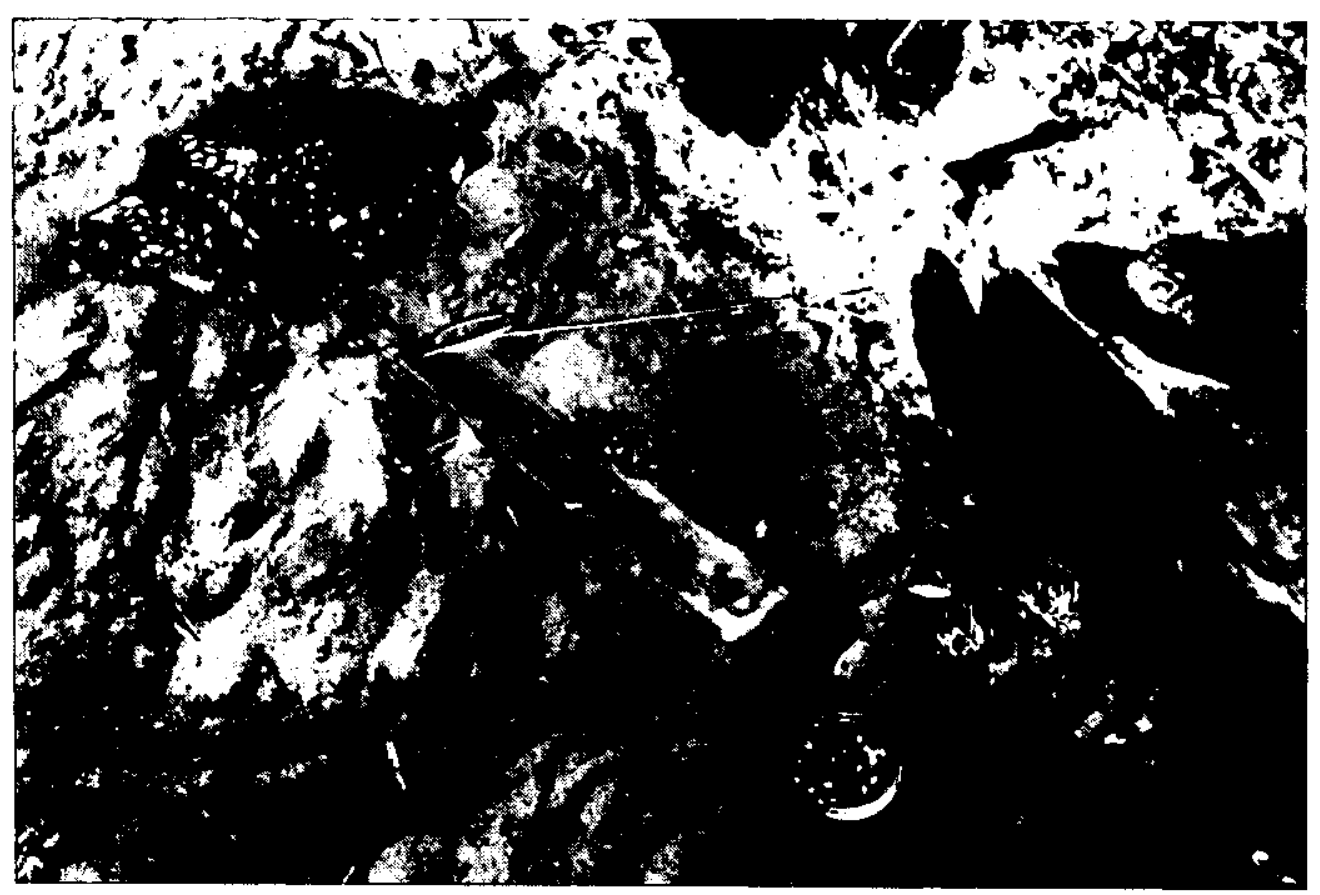

Plate 4.8 Burning holes through red beans for decoration at New Bore 
capable of supplying a modest living for a small group of people - not the hundreds of Aboriginal people living in the area. Cattle projects are even less likely to be successful today in Aboriginal communities for reasons already discussed in Chapter 2.

The Aborigines are not entirely unhappy about the decrease in cattle numbers as the kangaroo population has increased and the degraded vegetation has revived. The Aborigines described the country around Mt. Liebig for example as 'just dust' when they first resettled the area. Now it is thickly vegetated with grasses and shrubs. Both cattle and camels still present environmental problems at permanent waterholes such as Putardi and Ilpili Springs. Here the vegetation is over eaten and trampled and the animals have fouled the water with excrement. The men sometimes shoot female 'clean skin' (unbranded) cattle for meat but tend to leave the tough old bulls. At present the cattle population is unbalanced with many old bulls and few females. This is largely because of the hunting practices of the Aborigines and perhaps because the large population of bulls often kill the females during mating.

There has also been a limited involvement with Aborigines and goats in the Luritja Homelands. In 1977, for example the people at Black Water kept a herd of eight angora goats. These provided an irregular supply of meat as the people only killed one goat when a new kid was born. We do not know how long this herd lasted, but all that remains today is the tangled remains of the old goat pen. The only other interest the Aborigines have shown in animal husbandry has been a desire in 1978 by the Warren Creek people to acquire bees and horses. This didn't eventuate, although there are a few brumbies in the Luritja Homelands and the Aborigines do get honey from feral bees at Yai Yai Creek.

\section{Arts and Crafts}

Some camps in the Luritja Homelands supply arts and crafts to the Tula Artists Centre in Papunya. The only camps we visited that were obviously involved in this were Ili Ili, New Bore and Warampi. The owner of Ili Ili is a well known and successful painter and there were, a lot of paints and brushes at his camp. At New Bore the men had made some miniature coolimans, clubs and spear throwers from the softwood of local bean trees. These were among the poorest quality artefacts we have ever seen. The women at this camp were burning holes in red beans from the same bean tree to make necklaces also intended for sale (Plate 4.8).

At Warampi there were three full time artists at work. They were painting medium sized canvases (approx. $75 \mathrm{~cm} \times 1 \mathrm{~m}$ ) which sell for about $\$ 200$ and a large canvas (approx. $4 \mathrm{~m} \times 5 \mathrm{~m}$ ) which sells for up to $\$ 2,000$. This work displayed painstaking care and unique skill. The art work we saw was quite magnificant. One large canvas was intended as a backdrop for a successful rock and roll band originating from this outstation - the warampi Band. 
Chapter 5

Walpiri Homelands

Background

Before the turn of the century only three parties of Europeans had visited the Walpiri Homelands. The first of these was led by A.C. Gregory (1969) in 1856 and explored the northern Homelands in the vicinity of Hooker Creek. Later in 1862, Stuart (1863) led an exploration party through the western side of the Walpiri homelands and in 1873 Warburton (1875) led a party of seven through the heart of Walpiri country. Contact between these explorers and the Aborigines was minimal but more substantial incursions into Walpiri land occurred in the early 1900s with the discovery of gold at Tanami (Davidson 1905; Gee 1911). Meggitt (1962) claims for example there were 500 Europeans living on the Tanami goldfields at the peak of the gold rush in 1909 but this had declined to only six people by 1914. By 1917 a pastoral lease had been granted to farmers at Conniston and another was taken out at Mt. Doreen in 1926. Both stations occupied some of the best Walpiri land and in the case of Mt. Doreen, about 50 Aborigines attached themselves to the station within a few years of its establishment. These people earned rations by mining wolfram (tungsten) from the surrounding hills.

Clashes between Aborigines, miners and stockmen accompanied the European expansion into walpiri country and, as may be expected, were caused largely through competition for women, land and resources. Reprisals against Aborigines were harsh during this era and the best known is the Conniston Massacre of 1928. In this case minor thefts and the murder of a stockman by Aborigines brought about a punitive expedition in which 17 Aborigines were killed in a 25 day man hunt (Meggitt 1962, Young 1981).

A second gold rush occurred in Walpiri territory in 1932 and 150 white men went to diggings at the Granites for a short time. By 1943 there were 53 Aborigines living at the Tanami and 47 Aborigines at the Granites (Peterson et al. 1976). This led to the establishment of a ration depot at Tanami by the Government in 1945. This settlement contained 160 Aborigines, but their health was bad and the water supply was poor. As a consequence the people were moved to one large community of about 400 people at Yuendumu. Yuendumu has remained a walpiri stronghold ever since, with a few Anmatjira and Pintupi people camping on the fringes of the settlement. The last group of people to come into Yuendumu were Pintupi people from the Lake. Hazlet/Mackay region of the Western Desert (see Thomson, 1975). These people came to Yuendumu via Mt. Doreen in 1963 and it was this group that began the outstation movement by setting up Nyirrpi in 1975 .

The outstation movement which developed in the Walpiri Homelands has been relatively stable and co-ordinated and has displayed less of the helter-skelter frenzy which characterized the Luritja/Pintupi exodus from Papunya. The difference between the homeland movement in these two regions was probably due to the location of Yuendumu in Walpiri country originally and because the settlement was largely composed of Walpiri people. Thus there appear to have been fewer conflicts over land ownership and less racial tensions amongst the Walpiri than the Aborigines moving away from Papunya.

The reasons stated by Aboriginal people from Yuendumu for wanting to live on outstations were very similar to those of the Pintupi and Luritja 


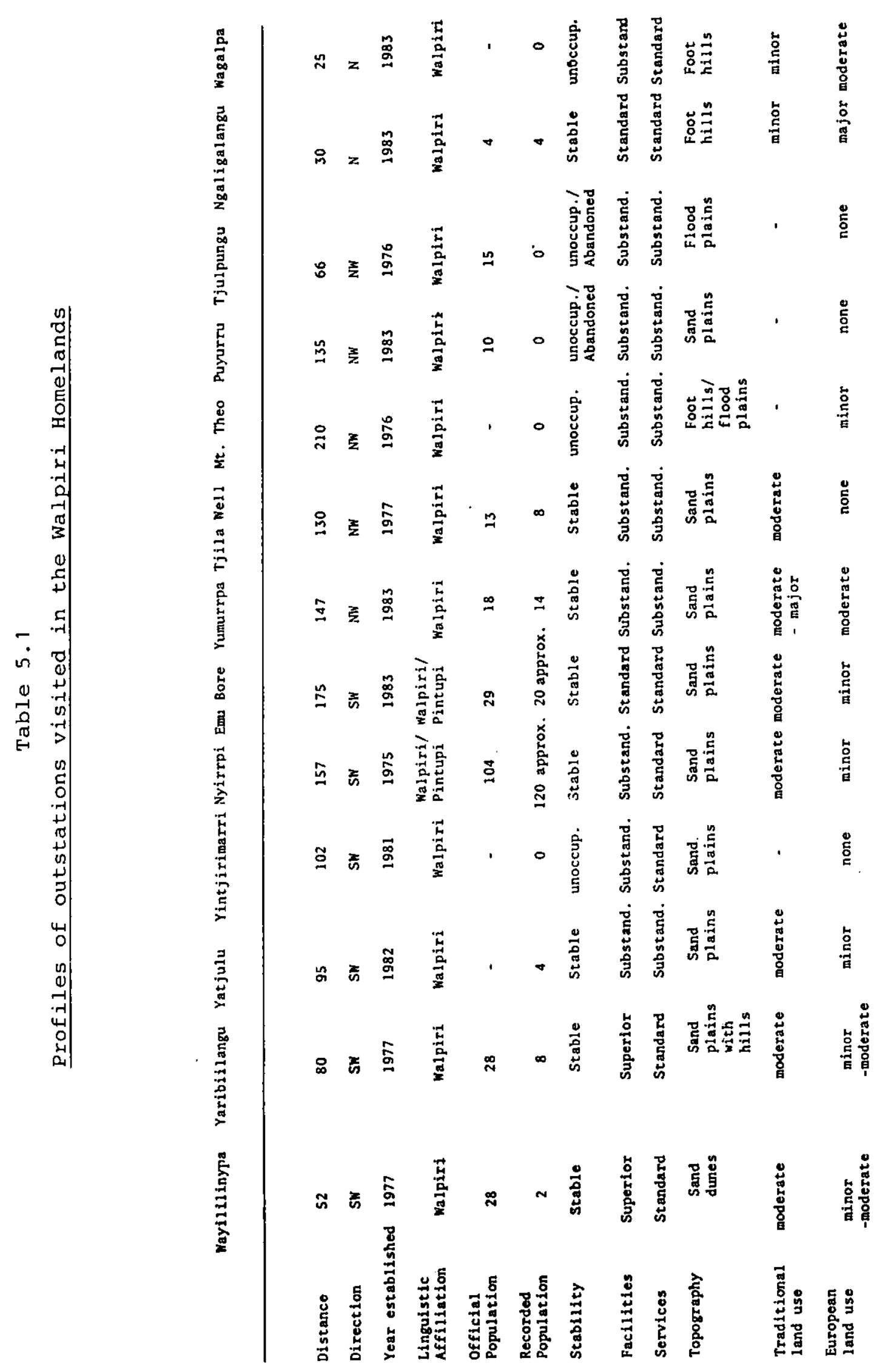


people. The most commonly stated were to escape the drinking and fighting at Yuendumu and because sites of significance (and the country generally) were not being looked after. The people said they also wanted to move so as to have more immediate access to bush foods and other resources such as firewood and ochre (see also Young, 1981; Kesteven 1978). Nathan and Japanangka (1983:113) also add that the Aborigines established outstations because they wanted places for their old people to live, and surprisingly, because government officials kept telling them to move and look after their country.

Over the nine years since the establishment of the first outstations at Nyirrpi in 1975 a total of 14 outstations have been set up in walpiri Homelands. In 1976 three camps were established. These were located at Ethel Creek, Tjulpungu and Mt. Theo but were only occupied sporadically at that time. In 1977 three new camps were set up at Ngana (now called Wayililinypa), Yaripiilangu and Tjila Well. Tjila Well was also established prior to the sale of the $2,613 \mathrm{sq} \mathrm{km}$ Chilla Well cattle lease to DAA in 1978. Apparently no camps were set up in 1979 or 1980 but Yintjirimarri was set up and occupied intermittently in 1981. Another new camp was located at Yatjulu in 1982 and a handful of new camps were begun in 1983. To date, these are the most recent of the Walpiri outstations and include Ngaligalangu, Puyurru, Yumurrpa, Granites, Emu Bore and Wakalpa.

The camp at Ethel creek has been the only camp in the course of this outstation development to have been abandoned. This group always had trouble finding water and used to alternate between two soaks located at Ethel Creek in the past. Bores were sunk at several locations in the region but failed to find water. The group are now camped at Emu Bore and Nyirrpi.

We visited 13 of the 15 outstations in the Walpiri Homelands during our two week trip to the region (Table 5.1). The only camps not visited were the Granites and Tanami as these were a long way north of Yuendumu $(250 \mathrm{~km})$ and were unoccupied at the time of our visit to the Walpiri Homelands.

\section{Location and Linguistic Affiliations}

The Walpiri outstations are located in two broad bands along main roads running north west and south west from Yuendumu. There are six outstations to the south west of Yuendumu. These are located along a main road graded from bush tracks which connected seismic lines cut during oil exploration in the region in 1971. In order of increasing distance from Yuendumu these camps include Wayililinypa (Plate 5.1), Yaripiilangu, Yatjulu, Yintjirimarri, Nyirrpi and Emu Bore (Fig. 5.1). The closest camp to Yuendumu in this part of the homelands was Wayililinypa $52 \mathrm{~km}$ from Yuendumu and the furthest was Emu Bore, $170 \mathrm{~km}$ from Yuendumu. Another six camps were located along the Tanami track running north west from Yuendumu to the Kimberleys. These camps included Tjulpungu, Mt. Theo (also called Yinabalgu), Yumurrpa (Plate 5.2), Tjila Well, Puyurru and the Granites (Fig. 5.1). The closest camp to Yuendumu in this direction is Tjulpungu. Tjila Well is central to these north western outstations and is $130 \mathrm{~km}$ from Yuendumu. The most distant camp is the Granites, $250 \mathrm{~km}$ from Yuendumu. Two remaining camps were located immediately north of Yuendumu. These included Wakalpa and Ngaligalangu, $15 \mathrm{~km}$ and $25 \mathrm{~km}$ north respectively.

With the exception of Emu Bore and Nyirrpi all these camps are owned and occupied by Walpiri people. Emu Bore and Nyirripi are also occupied by Pintupi people, although most of the Pintupi children at these camps grow up speaking Walpiri. This is a cause for some concern among the pintupi - 


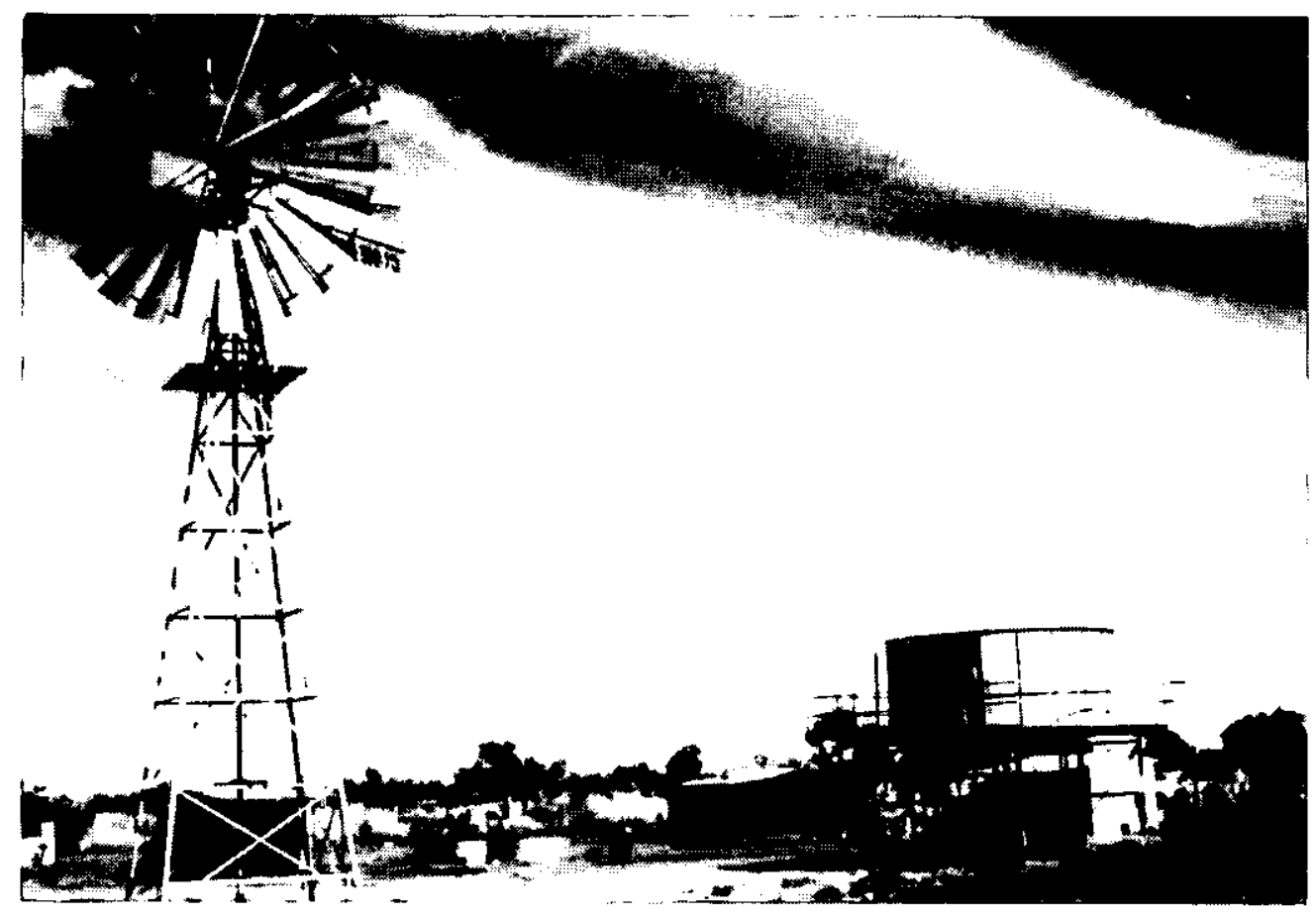

Plate 5.1 Camp at Wayililinypa

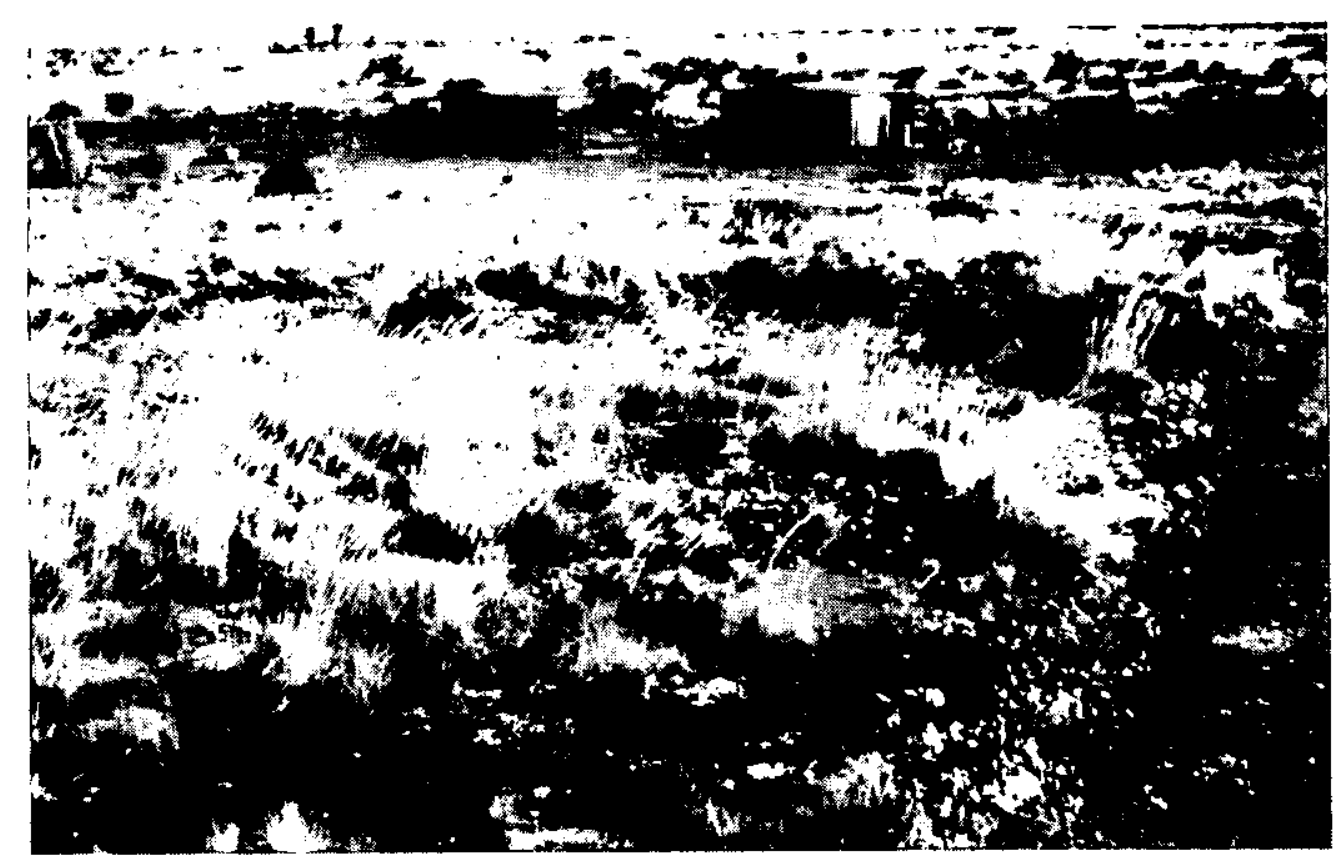

Plate 5.2 Camp at Yumurrpa 
Figure 5.1

Location map for Walpiri outstations

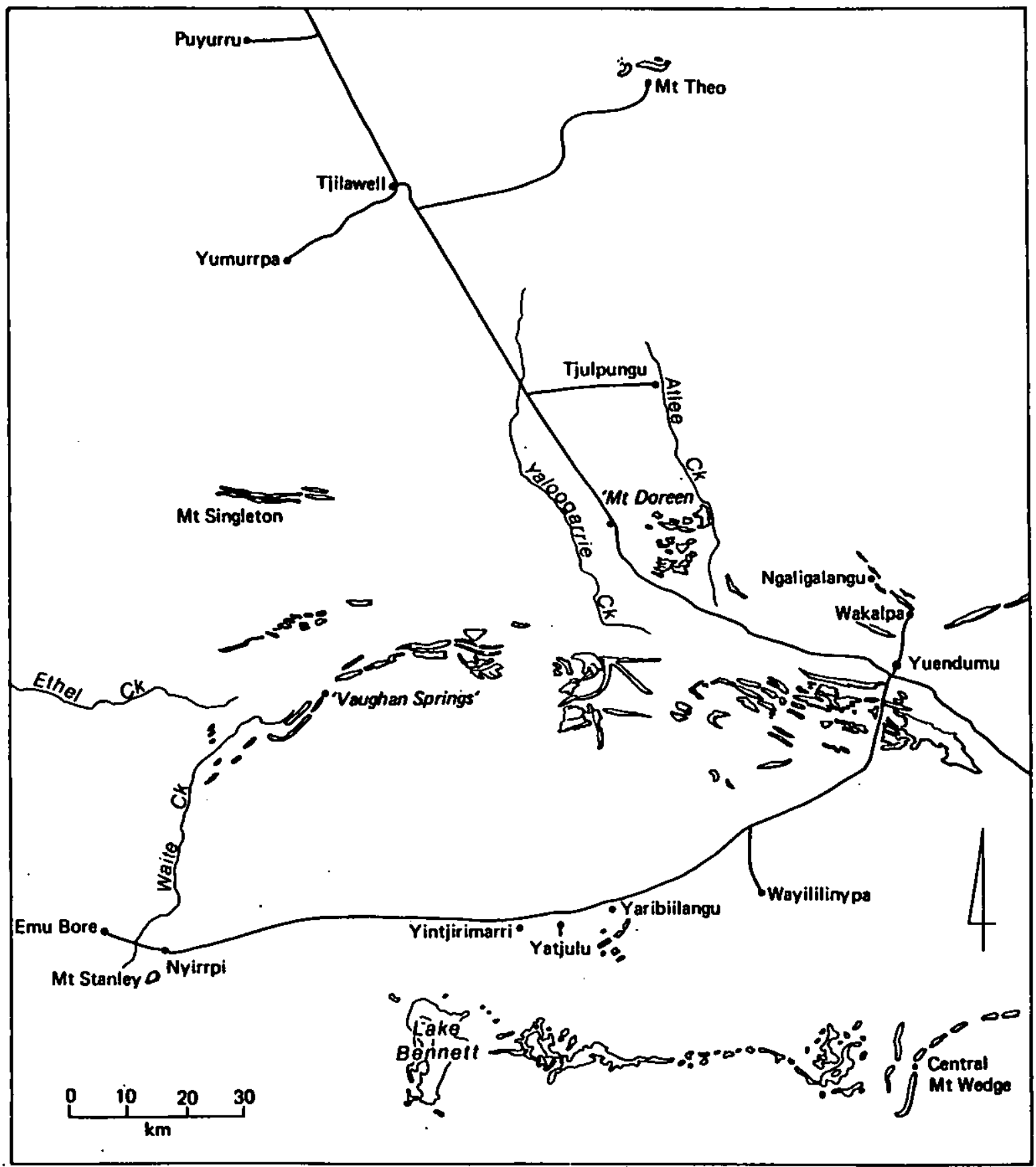


particularly as the Walpiri seemed so keen to point out that because of the language difference the children 'were Pintupi, but really walpiri now'. Many of the Pintupi people at that camp expressed a desire to continue to move west, towards Lake Hazlett and live in proper Pintupi country.

\section{Population}

Number and Composition

Eight of the 13 camps we went to were occupied at the time of our visit. These camps were Wayililinypa, Yaripiilangu, Yatjulu, Nyirrpi, Emu bore, Yumurrpa, Tjila Well and Ngalikalangu. Another three camps were unoccupied but obviously in regular use (Mt. Theo, Yintjirimarri, Wakalpa and two camps appeared to have been more or less abandoned (Puyurru, Tjulpungu).

The largest group of people were living at Nyirrpi (Table 5.1). There were probably about 120 people at this camp, although this figure is approximate as we found it difficult to count everybody with accuracy. The composition of the group seemed well balanced with at least 20 school age children and an even spread of adolescent, middle aged and old men and women. At the time of our visit the people from Emu Bore were also camped at Nyirrpi so the rather compact camp at Nyirrpi seemed quite over crowded. The Emu Bore mob were in the process of returning to their own outstation having participated in some ceremonial business at Nyirrpi. We took some people with us and their one four wheel drive vehicle made four return trips with people and gear from Nyirrpi. We estimated there were about 20 resident at Emu Bore - and once again this group consisted of many children and an even spread of adolescent, middle and old aged people.

The smallest number of Aborigines were camped at Wayililinypa. Here there were only two old women at camp, as their husbands and the rest of the group had gone to Docker River on 'business'. At Yatjulu and Ngalikalangu there were four people camped at each outstation. At the former there was one old man, a young man, wife and infant boy. At Ngalikalangu there were three middle aged women and a baby boy. There were eight people at $\mathrm{Tj}$ ila Well and this group included five old women, and an old man, his wife and grandson from Puyurru. At Yaripiilangu the group was more evenly balanced and contained one old man, two middle aged women, a young married couple, one young son and a young woman with an infant. The remaining camp, Yumurrpa, contained 16 people; six men, six women and four young children.

\section{Stability}

By and large the population on outstations in the Walpiri Homelands appears fairly stable. The number of people living at each of these camps rises significantly during weekends when relatives and friends come out from Yuendumu to visit. These visits had several purposes; often people brought children from Yuendumu to see their parents; often they delivered food and often came simply to enjoy a weekend away from Yuendumu. The use of outstations as weekend retreats for friends and relatives seemed an integral part of an outstation's function in the Walpiri Homelands and is a particularly common feature of outstation life elsewhere in arid Australia. At Yatjulu for example, five fresh regularly used sleeping fires established the presence of regular weekend visitors. 
In addition to weekend visitors at $\mathrm{Tj}$ ila well the population here also fluctuated because of its location almost directly on the Tanami track (see also Young 1981). The well here supplies the only drinkable water on the stretch of road between Yuendumu, Hooker Creek and Balgo and thus this camp was often used as a stop over by people travelling to and from these communities. Because of interruptions to camp life and the perpetual loss of food caused by a never ending stream of visitors the Tjila mob have placed their camp $1 \mathrm{~km}$ away from the bore and thus maintain a semblance of peace and privacy. The convenience of the location of $\mathrm{Tj}$ ila Well on the Tanami track has also meant that drunks returning from Rabbit flat to Yuendumu use the camp as a drinking and/or drying out stop.

The problems of alcohol and Aborigines are well known (see Brady and Palmer 1984) and we have referred briefly to some of the problems encountered at outstations in the section on population stability in the Luritja Homelands. It was our impression that most Aborigines and Europeans view the prospect of heavy drinking associated with the outstation development unfavourably although one Aboriginal man suggested to me that:

If they get drunk that's okay, come back to homelands, that's okay, come back to homelands. Sit down there. If they drink there, doesn't worry. But lot of worries at Yuendumu.

This individual was suggesting there is some merit in being able to have a quite, unmolested drink at your own outstation away from police, rivals, women and other causes of fights. He also alluded to the benefits of being able to sleep of $f$ a bad binge in the peace of the bush. We concede both points although the thought of the desert homelands turning into desert wetlands and the prospect of the movement being infiltrated and debased by a mob of drunks seems a real and depressing prospect.

Two of the three camps which were unoccupied during our trip (Mt. Theo, Yintjirimarri) were also used during the weekend although Yintjirimarri was not inhabited frequently as there was no water supply. The people from the third camp, Wakalpa, commuted daily to Yuendumu for work and spent evenings and weekends at the outstation. In this respect Wakalpa was more like an outer suburb of Yuendumu than an outstation.

By and large however, the Walpiri Homelands movement appeared to be stable and sound, even though there was quite a lot of movement between individual camps and from camps to Yuendumu. This $k$ ind of movement is characteristic of most outstations and in the Walpiri Homelands, as in other areas, occurred when people wanted to go out hunting, or wished to travel to different camps on 'business' or to see their children. At Yatjulu, for example, the people frequently travelled between wayililinypa and Nyirripi to fill 44 gallon drums with water, and travelled to Yuendumu for food. At Ngalikalangu the children went to school at Yuendumu and were brought out each weekend by relatives to see their parents. During the mustering season a large population of men used to camp and work at the cattle station at Ngalikalangu. The Walpiri people also spend much of their time away from camp gathering bush foods. While we were at Yatjulu and Yaripiliangu, for example, people were out collecting bush potato, goannas and bush tobacco. The day after we arrived at Tjila well, four old women went out, laden with bags, digging sticks and billies with water, for an overnight trip to collect bush potatoes. Several hours after arriving at Yumurrpa, the whole group climbed into a Dyna truck and went south to Mt. singleton for the night to collect bush tomatoes and hunt kangaroos. 
Similarly, ceremonial business was a major cause for movement among outstation dwellers. As mentioned above, the people from Wayililinypa were at Docker River on 'business' at the time of our visit and the people from Emu Bore had been camped at Nyirrpi on 'business' as well. Here the men were still covered in a silvery rouge like ochre (karrku) mined in one of the nearby mountain ranges.

A characteristic feature of outstation mobility in the walpiri Homelands seemed to be a relatively high degree of contact and social interaction between outstations and the main community at Yuendumu. Constant interaction between outstations and the main settlements was a feature of most outstations in all the homelands areas we visited, but was a little more obvious around Yuendumu than elsewhere, with the possible exception of Ernabella. There are several reasons for this. One of the most obvious is that the people living at Yuendumu and in the surrounding homelands are almost all Walpiri and still retain strong family, religious and economic ties with the people still living at Yuendumu. Furthermore, the outstation movement is also only nine years old and, as in other areas, people are still partly tied psychologically to the main community. One can imagine that after 30 years of living at Yuendumu the people still tend to see life as it revolves around that community. It is, after all, the centre for communication, health care, food, transport, education, entertainment (video, movies, sport, music) and the place people can go to make money, collect money, settle debts, see people, go to church, to obtain mechanical repairs, buy spare parts, get petrol and get access to vehicles. Thus, the mobility of outstation occupants is quite understandable and, should not be confused with a lack of commitment to the homelands movement itself. There is a notion, we think, amongst Europeans that once Aborigines move to an outstation they should stay there - much in the same way as white Australian families move to new suburbs and stay there; never visiting and never being visited by family. The situation amongst the Walpiri is of course very different. These poeple have very cohesive religious beliefs and have strong bonds with immediate $k i n$. They are a close-knit society and thus have to move about to see family, plan ceremonies as well as obtain supplies and services.

One of the greatest causes for outstation instability in this, as in other areas, has been the difficulty to finding water fit for human consumption. Because of this, three camps (Yintjirimarri, Tjulpungu, Puyurru) have been unoccupied for a long time and appear to have been more or less abandoned. Tjulpungu was originally located adjacent to a cattle bore at Altee Creek, but this continually sanded up and is now unoperational. Several bores have been sunk at Tjulpungu but the water has contained too many dissolved solids and is also undrinkable. At the moment people dig for underground water in Altee Creek when at camp. The people at Puyurru also have to live off soak water. Traditionally this soak was an important and reliable soak and has currently been dug to a depth of about $4 \mathrm{~m}$ to get water. Seven bores have been sunk at Puyurru but again no water has been found (see below). At Yintjirimarri a bore has been sunk and casing laid, although a hand pump is yet to be installed.

An additional reason for the absence of people at Tjulpungu was the recent delivery of a new toyota from ABTA funds. This vehicle was being used extensively and its arrival, in conjunction with the absence of water at that camp, had clearly destabilized the group (see also section on population stability in Chapter 4). Only last year this group was described as having 'great potential' (officially DAA file 77/22(3):91, 1983) and 'an especially high degree of commitment publicly (Nathan and 
Japanangka 1983:113) but when we were there no one appeared to have been at the camp for months. We did see people from Tjulpungu and the new vehicle, at Lander Creek, Yuendumu and Alice Springs however.

Mt. Theo also appeared to have been more or less abandoned. The Aborigines told us the people only used the camp in the weekends and that they were waiting for houses before they came out permanently. At the moment there are two humpies at the camp and a bore with a hand pump. The surrounding country is very good for bush food and the area is of significant mythological importance to the Walpiri people. Coombs and stanner (1974:21) originally indicated that this was the most likely location for outstation development in the area, claiming that 'the most firmly held intentions related to Mt. Theo'. Apparently 130 people then stated they wished to live there, but the place hardly seems to have been occupied since it was first set up in 1976. Kesteven (1978:63) recorded that Mt. Theo was thought of as a 'dangerous' place for women and children and she was not sure people actually wanted to set up an outstation there at all. In the light of the consequent pattern of settlement her original caution may well be justified and suggests that creation of the bore, installation of the hand pump $(\$ 3,000)$ and road being graded to the camp $(\$ 80,000)$ $(77 / 222(3): 188 ;$ DCD 1983) may have been premature.

It is probably worth noting that the pintupi people living in the Walpiri Homelands are likely to continue to push back to their country south of Lake Hazlett. Several men indicated firm desires to establish outstations further west, near Labilabi (a rockhole described by Thomson (1975) adjacent Lake Hazlett). The social and economic consequences of such a move may well be worth investigating before planning for the future development of outstations such as Nyirrpi, Emu Bore and Yumurrpa which are likely to be affected by such a move. The people at Yumurrpa also indicated they wished to relocate their outstation further south, nearer Mt. Singleton (there is a track from there to Labilabi). The present camp is conveniently located next to a windmill tapping an underground spring, but is uncomfortably close to a series of sacred stone arrangements. The men were talking about moving so women and children were not as close to the arrangements.

Houses

\section{Facilities}

The type of houses provided for Aborigines in the Walpiri Homelands are the same as those in the Luritja and Pintupi Homelands. These first stage houses are selected by Aborigines from the Luritja example and seem quite popular (see previous chapter). In fact, unlike the situation encountered in the Pintupi and Luritja Homelands where most of the houses were used. for storage and only camped in during the wet season, many of the houses in the Walpiri camps were either in use or the people were using the rooms for storage and camping underneath the verandahs.

At most of the outstations the number of first stage houses provided seemed adequate for the number of people occupying camps. In fact, given the number of people at some camps the number of houses allocated seemed extravagant compared with the housing allocation in the Luritja and Pintupi Homelands. No doubt most of these extra houses are occupied during weekends and holidays, but one cannot help questioning the justification of this when there are permanent residents at other camps without houses. For example there are six houses each at Wayililinypa and Yaripiilangu yet only two and eight people were at those camps respectively when we visited. Some 
of the group at Wayililinypa were away at the time of the visit and this may also have been the case at Yaripiilangu. The official population is 28 people at each camp and if this is correct then the housing allocation is justified (see DAA outstation profiles, although other files (83/050041:8) indicate only 10 and 15 occupants at these camps respectively).

The reverse is true at camps such as Nyirrpi, Emu Bore and Yumurrpa. At Nyirrpi there are only six houses whereas there are over 100 people at this camp. At Emu Bore there are only two houses for about 20 people and at Yumurrpa only two houses for 16 people. Clearly such a housing allocation is inadequate by comparison. Additional accommodation at these camps has been provided by humpies and windbreaks. We were also surprised to find that two first stage houses and 10 army tents had been provided at Tjulpungu and two first stage houses had been constructed at puyurru, whereas there were no houses at Mt. Theo. This was surprising because the people with the houses from Tjulpungu and Puyurru were not living at their camps because there was no water while the people from Mt. Theo were not living at their camps because there were no houses even though they had water. It would seem more logical to co-ordinate the allocation of houses with the provision of water and thus assist rather than frustrate the smooth development of the outstation movement.

We were also surprised to see that the materials for two houses had been purchased for Mt. Theo in December 1983 but had been left at Tjila Well. The gear was still there when we visited six months later and nobody, black or white, had done anything to put the houses up at Mt. Theo. The Aborigines had not attempted to take the materials to Mt. Theo, even though they said they were waiting for houses before moving to the camp. The houses will probably take even longer to construct now as children have opened and wrecked the bags of ready-mix cement left at Tjila well for the houses.

At the remaining camp we recorded two first stage houses at Yatjulu, Ngaligalangu and Tjila Well and five houses at Wakalpa. The number of houses at these camps seemed more or less adequate for the number of people using them. There were no houses at Yintjirimarri, but nobody was living there as their bore was not equipped with a hand pump.

Water

Eight of the 13 camps we visited had access to underground water (Yaripiilangu, Wayililinypa, Nyirrpi, Enu Bore, Yumurrpa, Tjila Well, Mt. Theo, Ngaligalangu). Among these camps, four had been provided with windmills, tanks and reticulation (Emu Bore, Nyirrpi, Yaripiilangu, Wayililinypa) and one (Mt. Theo) had a hand pump. The remaining camps had been equipped with windmills only. Bores and casing have been laid at Yatjulu and Yintjirimarri but these have not yet been equipped with hand pumps or windmills. Bores were drilled at the remaining three camps (Wakalpa, Puyurru and Tjulpungu) during 1984. Reasonable water was found at Wakalpa but the water at Tjulpungu was rich in dissolved solids (1730 $\mathrm{mg} / \mathrm{l})$, nitrate $(80 \mathrm{mg} / \mathrm{l})$ and fluoride $(1.7 \mathrm{mg} / \mathrm{l})$. At Puyurru seven bores have been drilled at a cost of $\$ 20,000$ (DCD 1984a) but no water had been found. This was probably the result of the drilling strategy in which the Aborigines directed the drillers to drill for water in more or less the same place.

At all but one camp (Wayililinypa) the quality of water at the Walpiri outstation was poor (Eig. 5.2). At four camps the water was very poor. At 
Figure 5.2

Water quality of camps in Walpiri Homelands

Total dissolved solits

Fluorlde

Nitrate
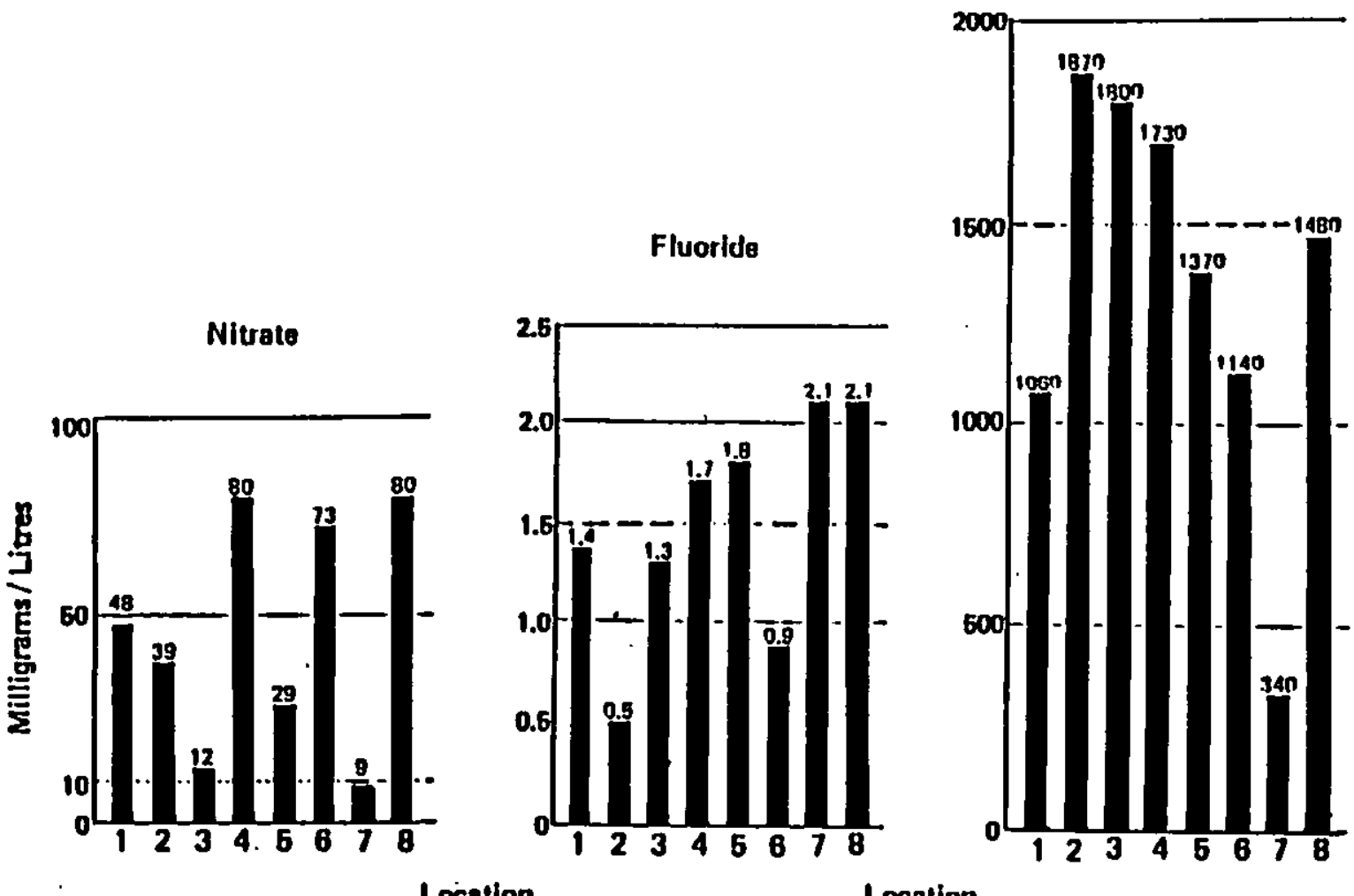

Location

Location

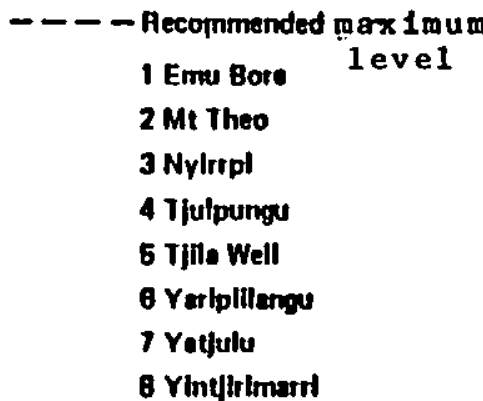


Ngaligalangu the fluoride content was very high $(3.5 \mathrm{mg} / 1)$. At Yintjirimarri and Yaripiilangu the nitrate levels were $\mathrm{high}(80 \mathrm{mg} / 1$ and $73 \mathrm{mg} / 1$ respectively) and at $M t$. Theo the water was high in chloride, salt and dissolved solids $(660 \mathrm{mg} / 1,1088 \mathrm{mg} / 1$ and $1870 \mathrm{mg} / 1$ respectively). Much of the Walpiri Homelands are (like the Pintupi Homelands) in an unfortunate geographic location for obtaining a good supply of water. Many of the camps are located out on the sandplains where the quality of underground water is generally the poorest. The best quality water is generally found near the hills - where captured run-off is still relatively pure. However, as the water travels underground it dissolves more and more chemicals and gradually decreases in quality as it moves from the foothills, under the flood plains, laterite plains and sandplains towards the salt lakes (Perry 1978: 84).

Often the Aborigines claim they are prepared to drink poor quality water. At Yaripiilangu, for example, the Aborigines said (as we have heard white people say) that they used to drink this water in the past and it did not do them any harm. This of course is not true as most of the waterholes used by Aborigines traditionally, contained surface water - collected annually from summer rains and thus not contaminated with nitrate. At a few locations such as Ilpili Springs in the Luritja Homelands and Yaripiilangu locally the people did occasionally live off springs which had a high level of nitrate. These springs however, were only used seasonally when supplies of surface water obtained from rockholes and soaks had dried up. As soon as fresh rains fell the people moved back to surface waterholes. Thus, in early times, any excessive amounts of nitrate absorbed by people living at these springs would have disappeared as soon as the people began to use fresh waterholes filled by summer rains again. Thus in the old nomadic days the Aborigines did not run the risks associated with the long term accumulation of nitrate and other chemicals that are faced by the more sedentary population today.

Radio Phones ('radios') and Toyotas

As far as we could ascertain all but six camps in the Walpiri Homelands have been supplied with radios. The camps without radios included Mt. Theo, Tjulpungu, Ngaligalangu or Emu Bore which were near Yuendumu or Nyirrpi but this was not the case at camps such as Yumurrpa and Tjila Well which were quite remote. All the radios supplied to the remaining camps appeared to be in working order except at Wayililinypa, where the solar battery and aerial were broken.

All camps except Mt. Theo and Wakalpa (and possibly Yintjirimarri - but we could get specific data here) had been supplied with community vehicles. At present $M t$. Theo is only visited rarely and on these occasions the people use private vehicles or a YMCA toyota from Yuendumu. People use private cars to travel to and from Wakalpa. At the other camps in the Walpiri Homelands (as elsewhere in the desert outstations) toyotas provide the means for considerable mobility among outstation dwellers (see also section on population stability in Chapter 4). The only evidence we saw of instability in the overall settlement pattern in the walpiri Homelands which was attributable to the arrival of a new toyota was at Tjulpungu. This group had a new toyota hi-lux and appeared not to have been at their camps since it arrived. We were under the impression however that the group would settle down once the novelty of the new vehicle wore off.

Outstation toyotas are also used on grog runs and new vehicles from Yumurrpa and Puyurru had been confiscated for bringing grog into a restric- 
ted area. This is a problem for people on outstations everywhere and one wonders if vehicle confiscation is the most appropriate punishment for grog running. Young men are usually responsible for taking vehicles and getting grog yet when caught the whole group from an outstation pays the punishment by losing access to the vehicle. It is difficult to know what the solution should be here, but we imagine justice would be better served by punishing the offenders directly rather than innocent people as well.

\section{Other Equipment}

An adequate quantity of hand tools and other gear appeared to have been supplied to the Walpiri outstations. We recorded that most camps had been allocated crowbars, axes, shovels, wheelbarrows, chicken wire, barbed wire, star pickets, PVC piping and garbage bins. Rubbish dumps had been graded by DCD at Wayililinypa, Nyirrpi, Yaripiilangu and Emu Bore at a cost of $\$ 3,000$ each (DCD 1984a) and all the other camps in the Walpiri Homelands except Puyurru were notably tidy and litter free.

While we were at Yuendumu an allocation of $\$ 16,900$ was provided by the Central Land Council for a $72 \mathrm{~km}$ fence between Tjulpungu and $\mathrm{Mt}$. Doreen Station. We were also informed that $\$ 1200$ had been approved for fencing at Wakalpa.

Other miscellaneous equipment was recorded at several camps. At Nyirrpi, for example, there were two prefabricated toilets and two shower units with solar heaters and basins. Obviously this level of servicing was inadequate for the 100 or so people living at this camp. Two prefabricated ablution blocks had also been supplied to Ngalikalangu. This camp is attached to an Aboriginal owned cattle enterprise and also had extra equipment such as a large shed, stock yard and troughs which one would expect of a cattle enterprise. The remains of an old cattle station surround the camp at Tjila Well. These include the old trucking yard, old cattle bores, trough, fence posts and tangles of wire, but these are mostly in disrepair.

\section{Services}

The two service centres in the Walpiri Homelands are Yuendumu and Nyirrpi. Yuendumu is obviously the major service centre and provides the local community as well as the outstations with health care, schooling, mechanical services, sports facilities, church and stores. Nyirrpi outstation is a minor service centre and contains a small store run by the Aborigines. This store is made out of a mobile truck container and is powered by a small generator. The Aborigines do not sell lollies at the store, but sold condensed milk, fruit juices, corn chips, tin food, fresh fruit and disposable nappies. There is also a small sunday school at Nyirrpi run by the United Pentecostal church. The priest cashes cheques for the Aborigines and runs pretty arduous church services. A health sister visits Nyirrpi regularly, stopping at Wayililinypa and Yaripiilangu on the way. The people from Wakalpa and Ngaligalangu are close enough to visit Yuendumu for health care so these camps do not receive visits from the sister or health workers.

As far as we could ascertain, there were no regular health visits to the northern camps around Yumurrpa and $\mathrm{Tj} i \mathrm{ila}$ Well and there was no part time school. The people in this northern band of camps did not receive the same level of servicing as those to the south west band from Yuendumu and had to commute regularly for food, schooling and health care. This appeared to be a significant factor explaining the relatively high mobility, low 


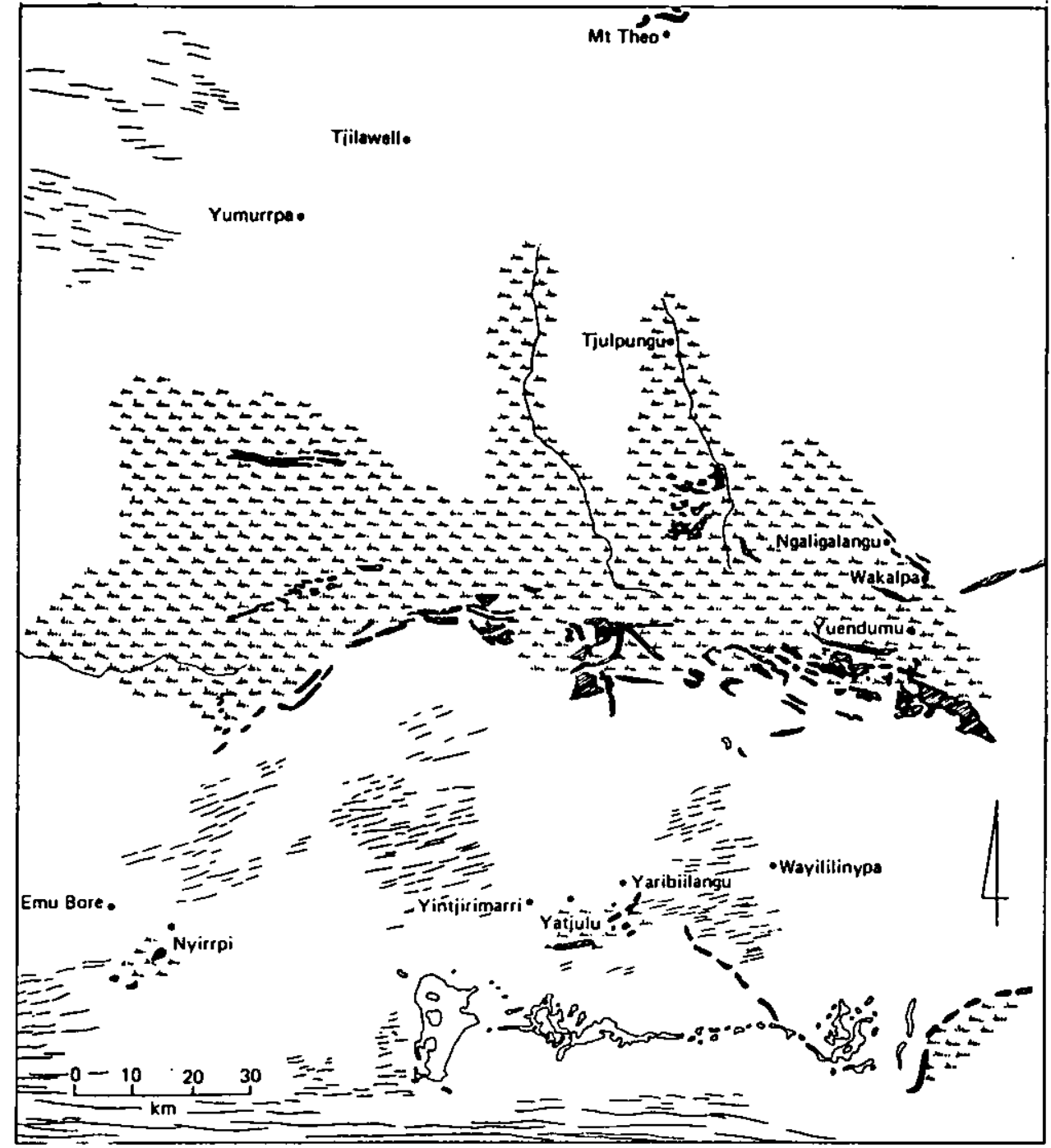

\begin{tabular}{|c|c|c|c|c|c|c|}
\hline UNIT & AREA & LANDFORM & SOIL & VEGETATION & TRAADITIIONAL & EUROPEAN \\
\hline & large & $\begin{array}{l}\text { Sandplains: flat or gently } \\
\text { undulating plains, little drainage, } \\
\text { part laterite. Some alluvial fans } \\
\text { near hills, occasional dunes. }\end{array}$ & $\begin{array}{l}\text { Red sands, red } \\
\text { clayoy sands. }\end{array}$ & $\begin{array}{l}\text { Shrub steppe; Spinifex dominant } \\
\text { (Triodis spp.), scattered shrubs } \\
\text { (Eucalypus, Grovilles, Hakee. } \\
\text { Acacia). }\end{array}$ & $\begin{array}{l}\text { Peptiles, wild } \\
\text { fruits, noctars, } \\
\text { tubers, wood. }\end{array}$ & Poor stock country. \\
\hline & medium & $\begin{array}{l}\text { Sand dunes: low, short dunes } \\
\text { with ' } v \text { ' shaped forks upwind. } \\
\text { Aligned S.W. N.E. in south and } \\
E \cdot W \text { in north. }\end{array}$ & Red sand. & $\begin{array}{l}\text { As above with Ploctrachne } \\
\text { schinzii, bloodwoods (E. } \\
\text { teminalis). Acacio stipuligera } \\
\text { on dune flanks. }\end{array}$ & As above. & $\begin{array}{l}\text { As above, part } \\
\text { consorvation area. }\end{array}$ \\
\hline & medium & $\begin{array}{l}\text { Foothills and flood plains: } \\
\text { brood shallow valieys, alluvial } \\
\text { fens, laterito in part. Opening } \\
\text { onto sandplains as large valloys, } \\
\text { with clay pans, alluvial fans and } \\
\text { drainage channels. }\end{array}$ & $\begin{array}{l}\text { Clavey sonds and } \\
\text { alluvial sands, some } \\
\text { gravelly rises. }\end{array}$ & $\begin{array}{l}\text { Mulga (Acecis mours) in groves, } \\
\text { adso witchetty bush (A. } \\
\text { kempoens). gidgoe (A. poorgina) } \\
\text { spinifex (Triodis spp.) and } \\
\text { woolybutt (Eragrostis eriopoda). }\end{array}$ & $\begin{array}{l}\text { Hardwoods, lerge } \\
\text { game; witchetty } \\
\text { grubs and reliabde } \\
\text { surfece water. }\end{array}$ & $\begin{array}{l}\text { Edible grasses. } \\
\text { shrubs, forbs. } \\
\text { suitable for catte. }\end{array}$ \\
\hline & medium & $\begin{array}{l}\text { Ridges and hills: granite and } \\
\text { oneiss hilts, sundstone and } \\
\text { quartzito ridges; relief up to } \\
\text { 150m above plains. }\end{array}$ & $\begin{array}{l}\text { Shallow and stonoy } \\
\text { soils. }\end{array}$ & $\begin{array}{l}\text { Grasses and stroy shrubs. } \\
\text { (Triodis picuts, Eucalyptus } \\
\text { brevifolis, A. enourd. }\end{array}$ & $\begin{array}{l}\text { Waterholes, wild } \\
\text { figs (Ficus plety. } \\
\text { poda), tobacco } \\
\text { (Nicotienia } \\
\text { bentieniens) } \\
\text { ochre. }\end{array}$ & $\begin{array}{l}\text { Watershed. } \\
\text { Inaccessibie for } \\
\text { stock. }\end{array}$ \\
\hline & minor & $\begin{array}{l}\text { Salt lakes; flat eveporatic busins } \\
\text { encrusted with walt }\end{array}$ & $\begin{array}{l}\text { Cov und waline } \\
\text { mud. }\end{array}$ & $\begin{array}{l}\text { None on laki floor, Molalacea } \\
\text { and sumphire around lake } \\
\text { mergins. }\end{array}$ & Nona. & None. \\
\hline
\end{tabular}

Table 5.2 Land Summary of Walpiri Homelands 
population and absence of children at these outstations although it is difficult to determine whether the lack of services was in fact the cause of the high mobility and low population or whether these characteristics were the reasons for the lack of services provided. Nevertheless, it was apparent that even the minor services provided by Nyirrpi acted as an anchor to the surrounding camps; much the same way as the services provided at Mt. Liebig acted as a stabilizer for the surrounding camps in the Luritja Homelands. It was apparent that the key store services offered by camps such as Mt. Liebig and Nyirrpi were appreciated by the Aborigines and attracted more people to the outstations. The larger population at these centres in turn drew other visitors to nearby camps. These factors tended to stabilize the existing population because Aboriginal people did not have to travel so far to see friends and relatives, participate in ceremonies, get store food and so on. Thus the outstations tended to be more regularly used, the people were more content and the camps contained much higher proportions of children and young people.

\section{Topography}

\section{Landscape and Landuse}

Topographically, the Walpiri Homelands are dominated by the sandplains of the Tanami Desert (Fig. 5.1; Table 5.2). The landscape is thus characteristically flat - broken only by occasional granite domes, sand stone ridges, creeks and calcareous and laterite rises. Longitudinal dunes only occupy a relatively small part of the sandplains, and exist as small irregular dunes in the southern and north western part of the homeland area. Mountainous country forms a band running more or less east west through the centre of the homelands. Much of this rocky country consists of granite hills rising up to $70 \mathrm{~m}$ above broad grass covering lowlands. A ridge of sandstone and quartzite hills runs west from Yuendumu to vaughan springs and south of Nyirrpi and Yaripiilangu where they form a broken chain of beautiful ridges and mesas.

Many large creeks run from the hills onto the surrounding sandplain and these are accompanied by large flood plains, numerous claypans and alluvial sand sheets. The largest of these creeks is Altee Creek, which runs north past Tjulpungu, waite Creek, south adjacent Nyirrpi and Yaloogarrie Creek which flows onto a large flood plain across the Tanami track north of Mt. Doreen.

Only two of the Walpiri outstations are located amongst the hills. These are Ngaligalangu and Wakalpa which are located at the foot of large granite domes north of Yuendumu. The remaining camps are located out among the sandplains although some of these (Yaripiilangu, Nyirrpi, Tjulpungu, Mt. Theo, Tjila Weli) are adjacent creeks, isolated hills and/or flood plains and thus have access to the various resources contained in these different environments.

\section{Climate}

The climate in the Walpiri Homelands is characterised by hot wet summers and relatively cold dry winters (Fig. 5.3). South easterly trade winds are persistent through most of the year. During the winter, skies are clear and the temperature varies between 22-25 degrees Celsius during the day and 5-15 degrees Celsius during the night. Frosts are unusual at this latitude and rainfall is slight as low pressure troughs moving over the south of the continent have little influence so far north. The driest 
Figure 5.3

Mean rainfall and temperature profiles for Yuendumu

\section{Temperature}

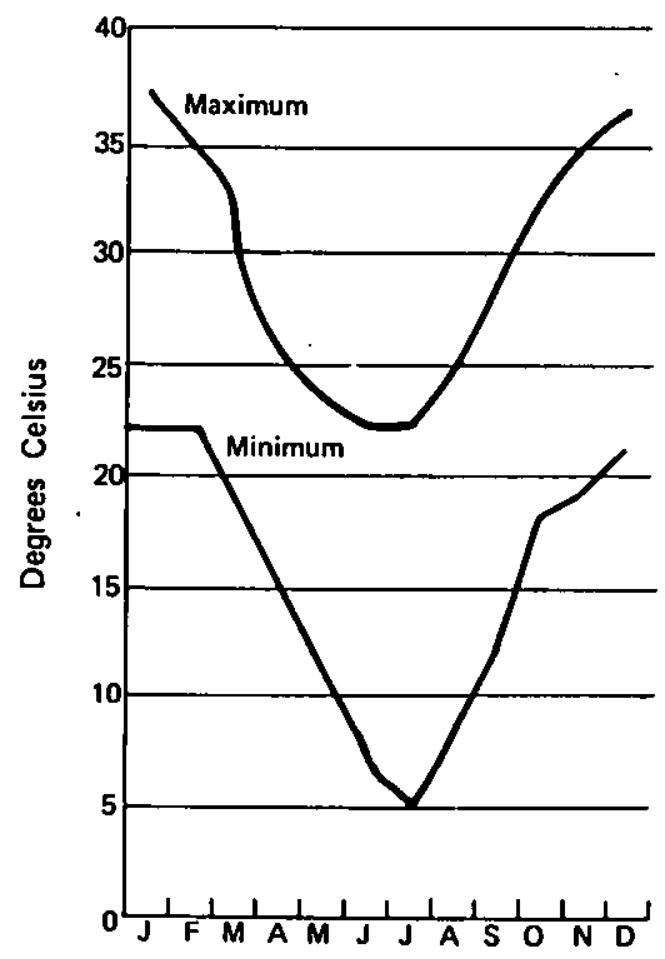

Rainfall

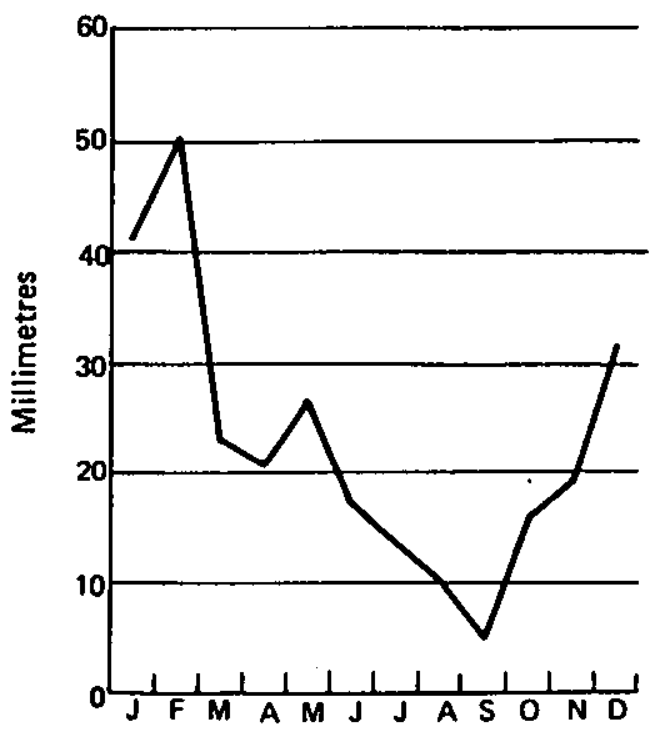


period of the year is spring, prior to the onset of the wet season. From November to March temperatures become very high, ranging from an average maximum of 32-37 degrees Celsius and a nightly minimum of 19-22 degrees Celsius.

During the summer intrusions of moist air associated with tropical lows interrupt the south easterly trades bringing humidity and sporadic rain in severe thunderstorms. December, January and February are the wettest months and the average rainfall is quite high ( $270 \mathrm{~mm} / \mathrm{year}$ ) although this is offset by extremely high evaporation rates (Bureau of Meteorology 1975).

\section{Vegetation}

Most of the vegetation on the sandplains can be defined as shrub steppe and is characterized by low, sparsely scattered shrubs (Acacia, Eucalyptus, Hakea, Grevillea) amongst a sea of spinifex. The large creeks which dissect this landscape provide welcome relief and support large red gums, coolibahs, and bean trees. The flood plains and foothills associated with the creeks and hills are vegetated by groves of mulga woodland and various other shrubs such as gidgee, A. cuthbertsonii, bloodwoods and various grasses and herbacious plants ( $\overline{f o r b}$ ). The granite and sandstone hills are sparsely vegetated with grasses, spinifex (T. 1ongicep), snappy gums and wild figs.

\section{Plants of Economic Importance}

The Walpiri Homelands are far enough north to enjoy milder winters than their Luritja and Pitjantjatjara counterparts and thus do not suffer the cold frosty winter encountered in those southern regions. Thus the walpiri people have access to vast expanses of bush potatoes. This is an underground tuber which grows widely on well drained sandplains. The plant has a geographic range extending north between Utopia and Tennant Creek and west in an arc across the top of the Tanami Desert to Balgo Hills and the Stansmore Range. Bush potato tubers are available all year round, are easy to gather and nutritious (see chapter 8). Consequently, they continue to be an important food resource for Aboriginal people in the Walpiri Homelands. We saw areas of bush potatoes around Tjila Well, Yumurrpa and all the camps located between Wayililinypa and Emu Bore to the south west of Yuendumu.

Other important foods collected from the sandplains by Walpiri people today include three species of bush tomatoes, nectars, edible grubs, and coconut apples. Important additional supplies of plant food grow near the creeks, claypans and swamps. From these locations the Aborigines fequently collect bush plums, witchetty grubs (from Eucalyptus microtheca), bush onions, native yams, and softwood for making implements. The flood plains and foothills supply less plant foods and here the most commonly collected are wild fruits such as wild oranges, wild cucumbers and konkle berries. The Aborigines also collect hardwoods, particularly mulga, from this environment for firewood and making wooden artefacts. Wild fig and wild tobacco are frequently collected from the hills and ridges in the walpiri Homelands.

Animals

As so much of the Walpiri Homelands is composed of sandplains, the overall population of kangaroos is probably less than in more fertile country found in the Luritja and Pitjantjatjara Homelands. Kangaroos and other large game generally only inhabit the sandplains after the wet 
seasons rains when they spread out with the abundant water supplies in search of food. Kangaroos usually spend the rest of the year amongst the foothills and flood plains where there is more shade, the feed is more nutritious and the water supplies more reliable. Thus, the most commonly collected animals from the sandplains in the Walpiri Homelands are reptiles, small marsupials (bandicoot, and mice) and edible grubs. Feral cats are also hunted enthusiastically and bush turkeys are relatively common on the sandplains. Turkeys are most abundant in the remoter corners of the Tanami Desert and are attracted to freshly burnt areas around camps.

As mentioned, kangaroos are most abundant on the mulga plains around the hills and in this environment the Aborigines also collect witchetty grubs from Acacia kempeana and honey ants during the latter part of the wet season. Euros, perentie lizards and echidnas are often hunted in the hills although echidnas are apparently less abundant today than in the past.

Camps and Traditional Land Use

One asset of much of the Walpiri Homelands not found in other homeland areas was the particular abundance of bush potatoes as well as other tubers and fruits. Because of this the Walpiri Homelands differ from the Luritja, Pitjantjatjara and Ngaanyatjara Homelands as these regions are comparatively poor in wild vegetable foods, but better supplied with large game. Consequently game is the major focus of the Aborigines in these southern homelands whereas vegetable foods constitute the major component of the foods collected by walpiri Aborigines. Traditionally this was also the case with anthropologists claiming vegetable foods constituted about 80 per cent of the foods eaten by Aborigines in this area (Meggitt 1962; Peterson 1978; Sweeny 1947).

Bush potatoes are still an important resource at most camps today and nine of the 13 camps we visited (Wayililinypa, Yaripiilangu, Tjila Well and Puyurru) were situated within walking distance of expanses of bush potatoes. While we were at Wayililinypa and Tjila Well, for example women were out collecting sweet potatoes. Bush tomatoes were also an important resource and when we were at Yumurrpa the whole camp spent a night in the scrub collecting them. This was clearly a regular occurrence. At Nyirrpi the children had collected piles of bush tomatoes using the traditional method of cleaning the fruit with wooden spatulas and threading the flesh on skewers of Sida virgata.

The traditional bent of the walpiri people for vegetable foods also reflected itself unexpectedly by the fact that some people still collected and ate some of the edible grass and acacia seeds in the area. Traditionally seeds were an important food supplement, but were very hard to process and were thus the first part of the traditional larder to be dropped when flour was introduced (see Cane 1984; O'Connell et al 1983; O'Connell and Hawkes 1981). Nevertheless the people at Nyirrpi said they used the seeds of dogwood a 'little bit' during the late spring and at Tjila well the women had traditional seed grinding stones which they said were for processing seeds. At Yumurrupa the people had collected and cleaned at least $4 \mathrm{~kg}$ of grass seeds (Fimbristylis oxystachya) for grinding.

Traditionally the Aborigines used fire to increase the yield of sweet potato plants and to increase the quantity and quality of the fruit bearing shrubs. Since the development of the outstation movement the Aborigines here, as in the Luritja and Pintupi Homelands, have again been pursuing a vigorous policy of burning the country. This is most apparent in Fig. 5.4 
Figure 5.4

Fire patterns in the northern Walpiri Homelands

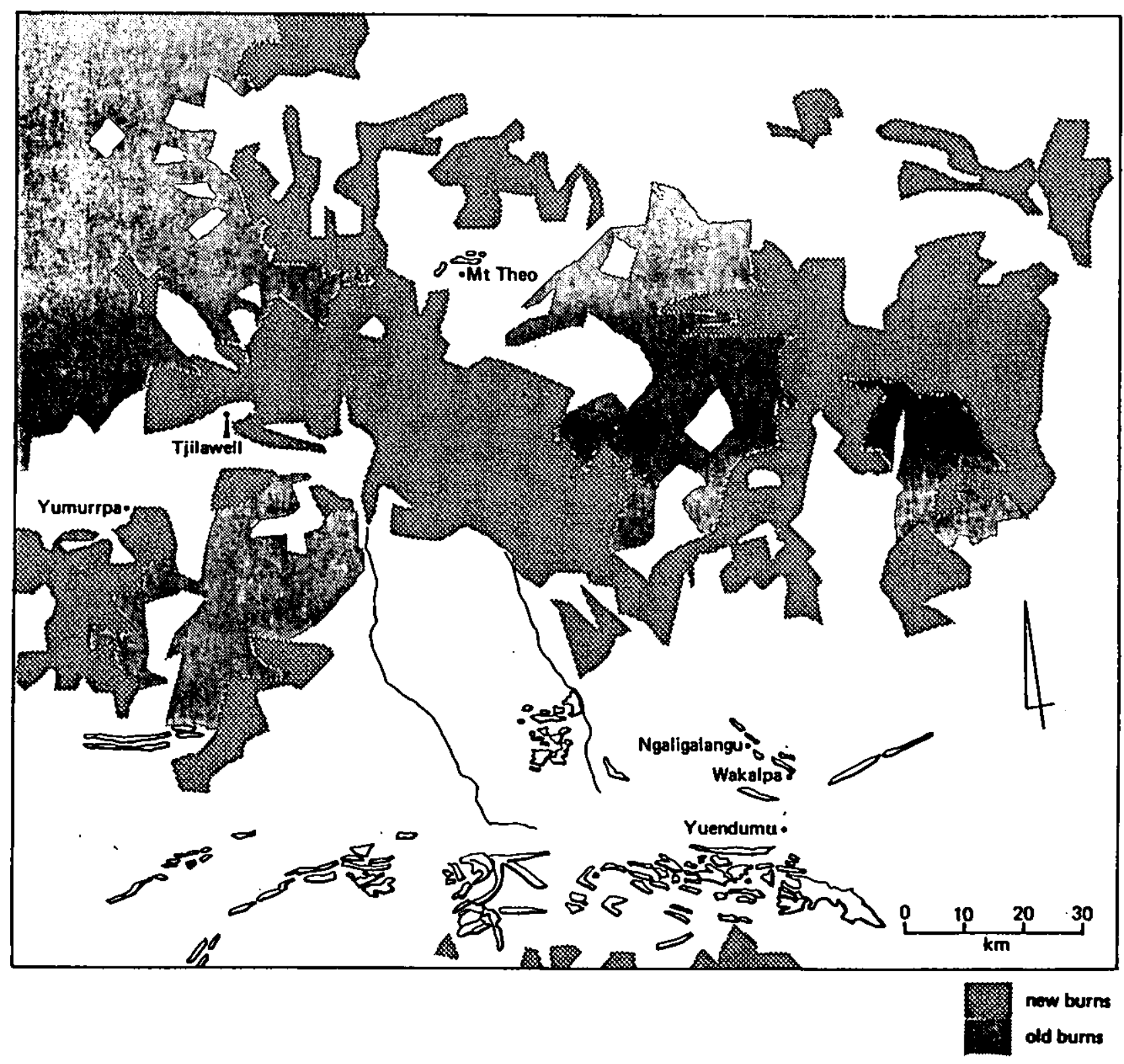


which has been redrawn from a satellite photograph taken of the northern half of the Walpiri Homelands in 1983. In this figure, there is striking evidence of the extent of the resurgence of the traditional custom of 'looking after' the country by burning it and thus increasing the productivity of the desert landscape around the outstations established in this region.

The Aborigines from outstations travel to the hilly country and flood plains when they hunt kangaroos. Most of this country is under lease to the pastoralists at Mt. Doreen and Vaughan Springs and although these Europeans are happy for the Aborigines to hunt on the properties they discourage the use of $\mathrm{fire}$ anywhere near their boundaries. The Aborigines said there used to be 'too many kangaroos' in the mountainous area and that there were in fact so many that the Aborigines claimed they 'couldn't manage him'. This however is not the case now and the Aborigines claimed that the 'bullock bin push him out'. This strikes us as most likely as the countryside in these pastoral areas is obviously degraded. In the Mt. Singleton area, for example, the grass cover and low shrubs are virtually gone. Large stretches of ground were completely denuded and all the accessible natural waterholes we visited had been trampled and fouled with excrement. We spent one long day in the Mt. Singleton area looking for kangaroo but did not even see any tracks. Traditionally this was good kangaroo country (see also Kimber 1976).

With regard to the outstations themselves, we found that there was evidence for a variety of bush foods in use. At wayililinypa for example, we saw a kangaroo and bush turkey pit and recorded evidence for the consumption of sweet potatoes, bush plums and coconut apples. At Yaripiilangu the people had hunted and gathered bush potato, goanna, euro (from the hills adjacent New Haven Station) turkey, kangaroo, bush tobacco, witchetty grubs and bush tomatoes. At Yatjulu, there were remains of goanna, bush potato and coconut apples. At Nyirrpi people were eating coconut apples, nectar (from Hakea suberea), kangaroo, bush tomatoes and goannas. At Emu Bore there were bush tomatoes and remains of turkeys at camps. At Yumurrpa the people seemed to use a significant quantity of bush foods and we recorded grass seeds, goanna, wild tomatoes, feral cats, kangaroo, turkey and bush potato. At Tjila well the people had collected bush potato, bush tomatoes, goanna, coconut apples and the women were burning a pile of broken twigs (probably Acacia curthbertsonii). to get ash to mix with wild tobacco.

Once again the quantity of bush food eaten at each camp varied. Various factors influenced this; some of which were the number of old people at camps, and each camp's access to vehicles and relative proximity to Yuendumu or Nyirrpi. Generally the closer a camp was to store and the more mobile a group was the more store food that could be bought and used at any particular outstation. We noted also, that when the younger people took vehicles into Yuendumu the old people often stayed behind, happy to enjoy the peace of the camps and forage a little in the bush. The availability of money also had a direct influence on the amount of store foods bought and thus indirectly on the quantity of bush foods gathered. As a general rule one could say that more bush food was collected in off pay weeks when the supplies of store food were running out. Store foods were also taken out to camps by visiting relatives during the weekends, but at the same time we noted that weekend visitars often came to outstations specifically to go hunting and collect bush vegetables and get away from the 'rubbish tucker' eaten at Yuendumu. Hence this had a balancing effect on the amount of bush food consumed at camps during the weekends. Unfortunately we were not in 
the Walpiri Homelands long enough to make a detailed quantitative assessment of the amounts of bush food incorporated in the outstation diet. Nevertheless, our impression was that bush food was probably about as important here as in the Luritja Homelands; constituting between 20-30 per cent of the diet.

In addition to using the land to obtain food the walpiri also collected wood (particularly mulga) to make wooden implements, sacred boards and for building shelters and firewood. The Aborigines also used traditional adhesives made from spinifex resins and kangaroo sinews, and we noticed at Nyirrpi, Emu Bore, Wayililinypa and Yumurrpa that the men had traded hunting spears from Pintupi people west of Kintore and had traded steel tipped bamboo spears from Balgo. Bamboo spears are used in ceremonies and had come to Balgo from Fitzroy Crossing in the Kimberleys. These spears had thus been traded a distance of approximately $1000 \mathrm{~km}$ into the Walpiri Homelands.

Another traditional resource of great importance to the Walpiri people is a highly prized vein of red ochre in a mountain near Nyirrpi. This ochre is made of pure haematite (a valuable iron ore) and has a rich rouge red lustre. The Aborigines have probably been mining this for thousands of years and the quarry extends about $80 \mathrm{~m}$ under ground (Peterson pers. comm.). The ochre is traded extensively throughout the desert and as far as we are aware, the only other mine of comparable quality in the entire region was a small quarry near kings Canyon.

\section{European Land Use}

The Aboriginal people living in the Walpiri Homelands use European methods of land use in three ways; incipient gardening, camp improvement and small scale animal husbandry. Gardens, as an outstation enterprise, do not appear to have been as entrenched in the history of the homelands development in this region as was the case among the Luritja camps. In fact the only places that appear to have had any sort of garden prior to the 1980 s were Nyirrpi, (file 77/222 (2):125) and Tjila Well (Kesteven 1978:57). Neither of these gardens are in existence today and the Nyirrpi garden appears to have deteriorated by 1981. Some camps have what may be described as incipient gardens consisting of small patches of cultivated ground near taps and houses. These gardens usually contain a few vegetables or fruit trees, but often involved no more than the planting of a few fruit trees scattered randomly in the camps. At Emu Bore for example, the Aborigines had planted a mulberry tree and at Yumurrpa they had planted one grape vine and an orange tree. Some camps, however, had demonstrated a little more horticultural endeavour and at Wakalpa for example, several grape vines had been planted and trellised. At Nyirrpi one family had planted a row of cabbages and tomatoes. These were well watered from a nearby tap and appeared healthy. The people had covered the plants with chicken wire to protect them from children but they also needed covering with shade cloth and required thinning out. The people at Wayililinypa had planted a variety of fruit bearing plants. These included a few watermelons, mulberry trees, grapes and chestnuts.

The most ambitious gardening project had been undertaken at Yaripilangu. Here the people had cleared a couple of hectares and said they were intending to plant an 'orchard'. Apparently this project had been encouraged by the example of a rather large citrus orchard nearby at Newhaven station. At the time of our visit the Aborigines had planted 12 orange, lemon and grapefruit trees and these were watered by drip irrigation from two taps. No doubt this exercise is very commendable but we found 
it difficult to imagine what use the crop of predominantly lemon and grapefruit trees could be to Aboriginal people. There appeared to be plans to sell the fruits eventually, but lemons and grapefruits are hardly likely to be popular with the local Aborigines and the potential of the Alice Springs market must be severely limited. There are already many citrus orchards around Alice Springs and most suburban families grow their own citrus trees. The people at Yaripiilangu also face the problem of actually producing a ripe crop for harvest as children are likely to destroy the fruit before it is ready. We recall talking to Johnny Liddle at the Central Australian Aboriginal Congress about this and he said that even in the grounds of Congress the children always pull the fruit off the trees before they ripen. If the orchard was intended to improve the nutritional status of the homeland communities by supplying fruits rich in vitamin $C$ the project is equally ill conceived. Aborigines would be wiser to collect some bush tomatoes, shed the seeds, burn the grass and let a crop of wild tomatoes grow. Wild tomatoes grow at most camps anyway, particularly where seeds have been discarded from fruit brought into the camps and these have virtually the same nutritional content as domestic oranges and lemons (see Chapter 8).

Also of particular interest at this orchard was that the cleared ground had begun to be colonized by bush potato (Plate 5.3). This is interesting because it raises the obvious possibilities of domesticating and intensifying the yield of wild bush potatoes at outstations. Bush potatoes are very productive and if the runners are planted by hand and the established bushes burnt regularly each spring they could provide a popular, abundant and nutritious supply of food to outstations in the Walpiri Homelands. (One wonders if, when the time comes to plant more lemon and grapefruit trees, the Aborigines and European advisors will clear away the bush foods in favour of more fruit trees).

One of the obvious characteristics of the horticultural exercises of the Walpiri Homelands was that, like the Luritja examples, the Aborigines generally appear to have forsaken the larger European style gardens in favour of small, more manageable gardens which contain plants that are nice to eat and easy to grow. It was also apparent that in the Walpiri Homelands this incipient form of Aboriginal horticulture was more established than in the Luritja Homelands and generally (despite the inexperience of the Aboriginal men) the gardens were relatively well cared for and maintained. We noted in the previous chapter that these small gardens might be the beginnings of an attempt by the Aborigines to adapt the advantages of European horticultural methods and some of the more desirable plants to the outstation environment and suggested that from these humble beginnings one may see substantial horticultural development in the future. Our impression of the gardens in the Walpiri Homelands tends to confirm this.

Further to this speculation over the Aborigines' interest in gardens it is worth noting that the people at Yumurrpa stated quite clearly that they did not want a garden. We found this information refreshingly frank because at some camps, both here and in other homelands, people often demonstrated insipid and unconvincing enthusiasm for European style agricultural enterprises. The people at Yatjulu, for example, expressed interest in establishing 'a market garden'. The people at Yaripiliangu wanted an 'orchard'. The people at wayililinypa said they wanted a'little station' and the people at Tjila Well said they were going to 'have a farm'. It may well be that these intentions will be realized but it was our impression given the progress made so far, that these plans were no more than the result of pressure and encouragement from Europeans. We also felt 


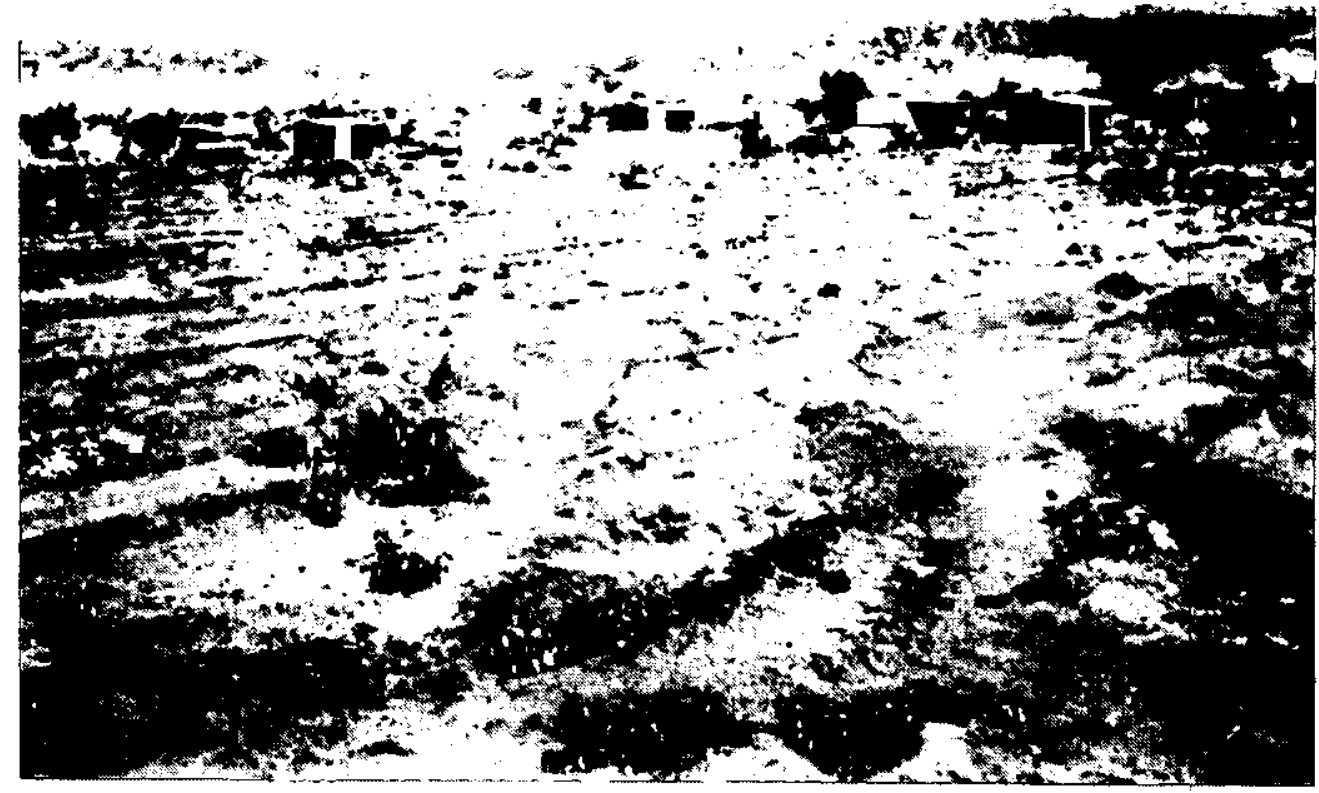

Plate 5.3 Cleared area for orchard at Yaribiilangu. Note bush potatoes (dark bushes) growing in foreground.

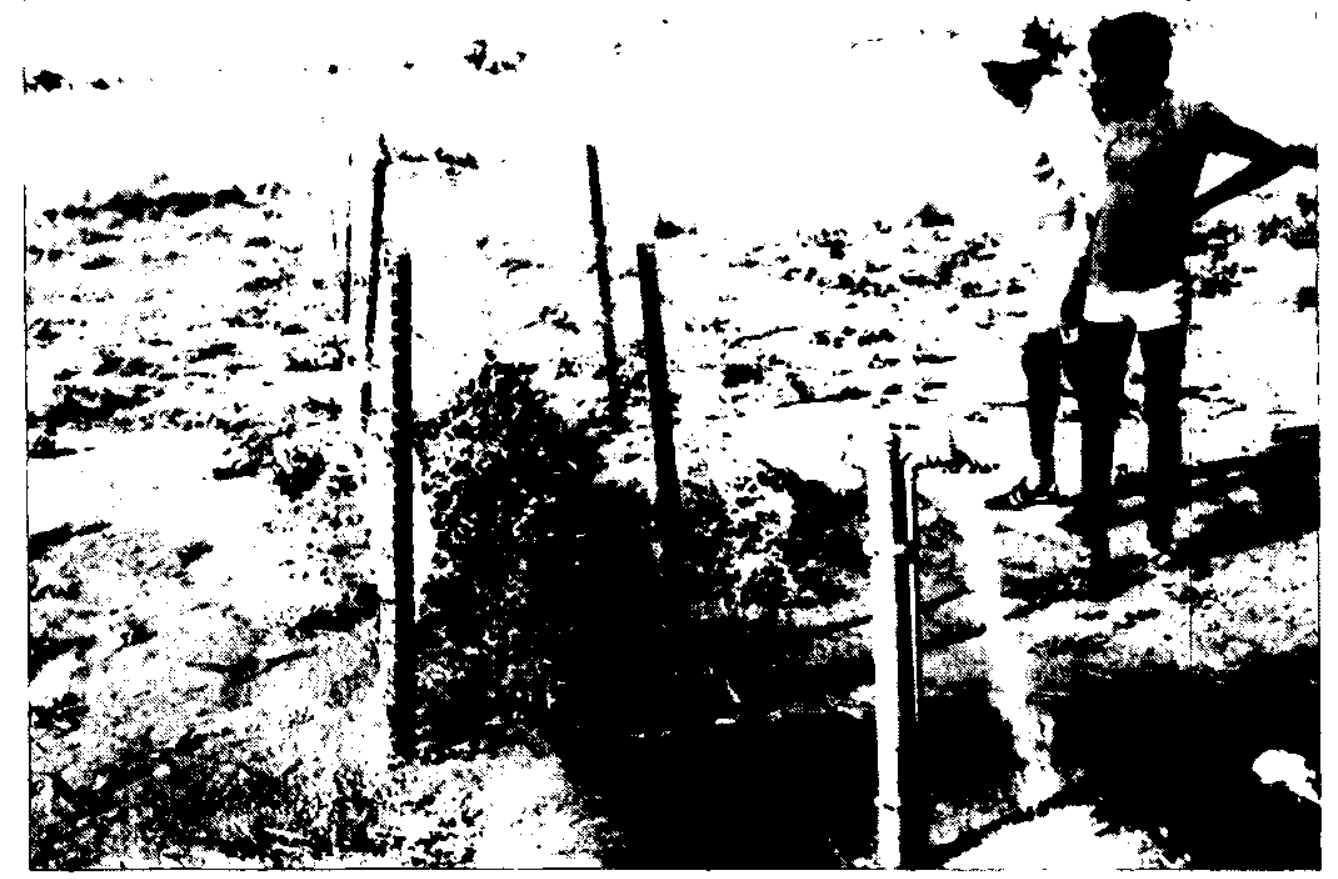

Plate 5.4 Row of bean trees planted at Emu Bore 
the Aborigines were trying to display enterprising plans in the hope that they would gain extra funds in the future. We do note however that activities such as the planting of trees, establishment of gardens and fencing of outstations are used as yard sticks among government and nongovernment people in assessing the 'potential' and 'degree of commitment' of Aboriginal people to outstations (see Nathan and Japanangka 1983:113, 134). This strikes us as unreasonable and unnecessarily ethnocentric.

Developing alongside the small scale gardens described above have been several attempts to improve the appearance of camps and, in a rather European style, provide shade and shelter using exotic and native trees. The most commonly used native trees were red gums, coolibahs and bean trees. Bean trees were particularly popular in this region as they grow quickly and easily from seeds. At Nyirrpi, for example, several rows of bean trees had been planted between camps to provide shelter and privacy. At Emu Bore a row of bean trees had been planted next to a tap about $200 \mathrm{~m}$ from the camp (Plate 5.4). We cannot imagine what possible use this row of trees could be to the camp and suspect it was the nearest the group have come to planting a garden.

At almost every camp at least a few trees of one kind or another had been planted. At some camps the Aborigines had done this quite successfully and to our eyes the camps looked very nice and were well shaded. At Wayililinypa for example, the camp was set under the shade of two large desert oaks and people had planted eucalyptus and white cedar trees and were growing a deciduous climber (chinese lantern) over the verandahs of some houses (Plate 5.5). Some people had even planted a few patches of lawn around their houses. Similarly, at Yaripiilangu the people had planted cactus, bamboo as well as eucalypts and bean trees. At Wakalpa and Ngaligalangu, the people had planted pepper trees and coolibahs. At Mt. Theo some bamboo and a couple of eucalyptus had been planted. The people at Emu Bore had put in cedar and eucalyptus trees and at Puyurru the people had planted a bean tree.

We also observed that most of the camps in the Walpiri Homelands had been fenced or had been provided with fencing materials. The fences we saw had been constructed with desert oak, star pickets and eight gauge wire and barbed wire. These fences always struck us as out of character, both within the nomadic and social context of the Aboriginal lifestyle as well as the remote locations of the camps themselves. By constructing these fences one was led to wonder what the Aborigines were trying to keep out, or what they were trying to keep in. We noted the same tendency to fence outstations almost everywhere we went in Central Australia and have suggested already (Chapter 3) that the construction of fences is probably an attempt by Aborigines to make their camps look 'nice' and impress visiting Europeans. This is understandable, but unfortunately the fences imposed a tasteless suburbanization on what is otherwise an unbridled and beautiful environment.

Some of the people at outstations also had a rather interesting involvement in animal husbandry. This goes back a few years at some camps with, for example, the old camps at Wayililinypa (then called Ngana) and Tjulpungu having goats, a few camels and/or chooks. Today this interest appears to have developed somewhat and we recorded sizeable quantities (i.e up to 18) chooks and ducks at Wakalpa, Yumurrpa, Yaripiilangu and Nyirrpi (Plate 5.6). Two camps (Emu Bore and Wayililinypa) even had little concrete duck ponds at the outflow from their water tanks, but neither had any ducks and their chook pens were empty. One of the most curious aspects of the Aboriginal involvement with domesticated animals was their use of poultry. 


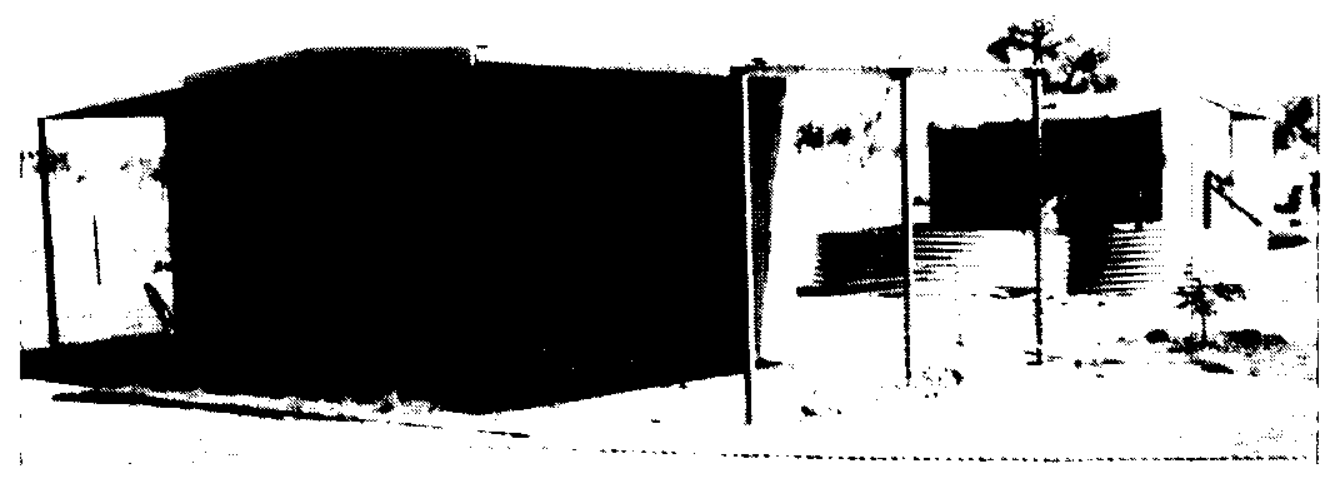

Plate 5.5 Planted trees, Chinese Lantern and attempted lawn growing at Wayililinypa

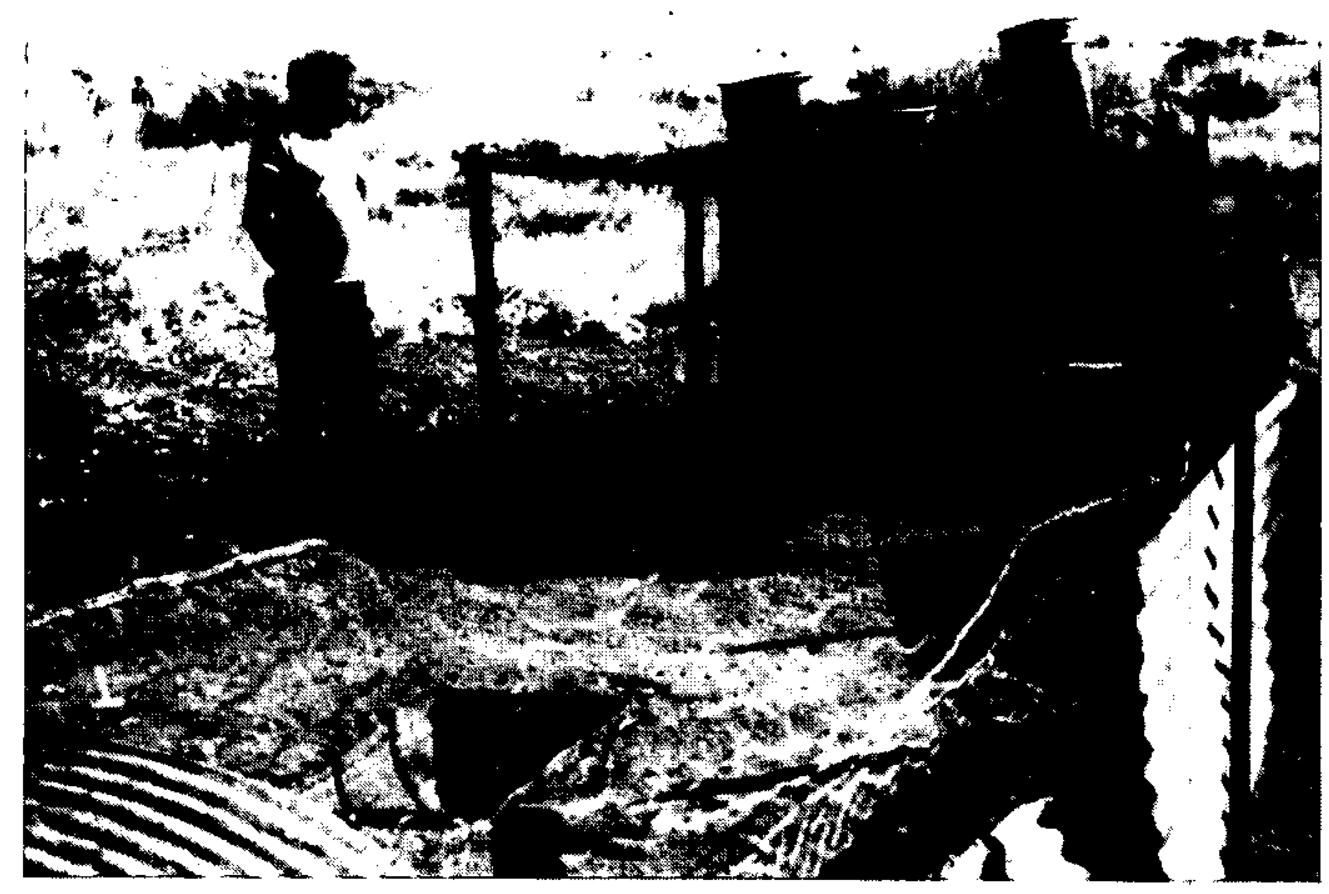

Plate 5.6 Chook pen at Yumurrpa 
When, for example, we asked the Aborigines why they kept poultry they replied they 'didn't know'. When asked if they ate the birds they also replied 'no', and when asked if they ate the eggs they again replied 'no', as the children usually broke them first. Whenever the Aborigines left their camps for more than a few days, the poultry were usually eaten by feral cats or dingoes. Hence the empty pens at Emu Bore and Wayililinypa.

The people at Wakalpa and Wayililinypa had also tried to keep goats in the past. At Wayililinypa the goats had simply walked away whereas at Wakalpa they were said to be living in the hills behind the camp. The problem of wild goats in the desert presents potential environmental problems. Goats are generally seen as a major threat to arid land habitats although it is also argued that they use and live in areas such as rocky mountains which are inaccessible to man (Heathcote: 1983:98; Kolars $1966: 583)$. This point however raises potential problems for Australian arid lands where feral goat herds are in direct competition with euros and rock wallabies (Denny 1983), animals that are an important source of food for Aborigines.

Two camps, (Tjila Well and Ngaligalangu) have had some involvement with cattle and a third camp, Wayililinypa expressed interest in setting up a 'little station'. The prospects of the latter venture are low as the country around Wayililinypa is largely spinifex plains and of little or no value to stock (Perry, 1960). We have no data on Ngaligalangu, except the Aborigines claim that they were 'building up the cattle' there, as we could not get access to various files on this outstation and the station manager was not in Yuendumu at the time of our visit. Tjila Well was occupied in 1978, when DAA bought the Chilla Well cattle lease. The outstation occupants have expressed interest in running a cattle operation, but this has never eventuated and the property and equipment are in disrepair (see also Nathan and Japanangka 1983; Kesteven 1978). The likelihood of this outstation ever running a successful cattle operation is very remote. This is not, as some Europeans are apt to think, because the Aborigines are too lazy and disorganized, but because the surrounding country is so poor. From the time the lease was first taken up at Chilla Well (1959) the property only supported a maximum of 400 head of cattle. Inspectors' reports during that time noted that these cattle were in 'very poor condition' and had to 'walk a long way for food' (Low 1984). In 1964 the cattle were living 10-15 km from the bore and were reported to be 'starving to death'. The property had so little potential that the owner walked off the property in 1964. In 1966 there were only 200-250 head of cattle surviving in the general area and this had declined to 120 cattle by 1969 . By 1980 there were only six head on the lease - most of the others had probably walked to Vaughan Springs Station or died. Thus, it is apparent that the potential of the Chilla Well cattle lease is very low and one suspects it would be pointless to develop the Tjila well outstation as a cattle enterprise.

Finally, some outstations are involved in the sale of artefacts and wild seeds to Yuendumu. The Aborigines usually collect acacia or eucalyptus seeds and these are brought by an agent in Alice Springs who sends them to a buyer overseas. The Aborigines usually collect seeds when word is spread from Yuendumu that the buyer has a contract. The Aborigines get paid about $\$ 25$ a bucket for seeds and collect them with enthusiasm when they have the opportunity. The last time the agent required seeds from Yuendumu the Aborigines collected and cleaned four tonnes of them in just a few weeks. The Aborigines were paid, but unfortunately, the agent has not yet found a buyer. A more systematic approach to marketing is clearly required if this enterprise is to succeed. 


\section{Chapter 6 \\ Pitjantjatjara/Ngaanyatjara Homelands}

\section{Background}

Contact between Europeans and Aborigines in the general vicinity of the Petermann Ranges was significantly earlier and more concentrated than in the homeland areas in the north described so far in this report. There appear to have been two phases to the European occupation of the Pitjantjatjara/Ngaannyatjara Homelands; a period of exploration until 1930 followed by more substantial excursion and settlement after 1930. A relatively large number of explorers had crossed through the region prior to the 1930s. The most famous of these was probably Giles (1889) but contemporaries of his to visit the region included Gosse (1874), Tietkens (1891) and later, Spencer and Gillen (1912), Basedow (1914), White (1915), McKay (1926), Terry (1931) and Lassiter in 1930. Several pastoral stations were also set up in the general area prior to the turn of the century (Erldunda; established before Tietkens crossed in 1889, Temple Downs in 1885, Henbury in 1877). An Aboriginal reserve was established in 1920 which included the Petermann Ranges (Layton and Rowell 1979) but by 1937 this was apparently criss crossed with well defined tracks from camels and motor cars belonging to doggers. Doggers had extensive contact with the Aborigines from whom they bought dingo scalps and sexual favours from women. Following the doggers came more pastoralists (Curtin Springs and Mulga Park in the 1940s), missions (Ernabella Mission 1937, Warburton 1934), prospectors, air strips and roads. Accordingly there were many white and black clashes like those recorded elsewhere in Australia (see Layton and Rowell 1979; Toohey 1979). Throughout this time the Aborigines had begun moving towards cattle stations, missions and settlements and in 1937 strehlow (1968:9) found 'only a few scattered groups of nomads' in the heart of Pitjantjatjara country. The last people to leave this region were a Ngaanyatjara group from Kutjuntari (Plate 6.1) near Gill Pinnacle. This group contained 17 people who had obtained European goods (blankets, billies, clothes) from doggers and to whom flour, tea and sugar were distributed every three months by a truck from Woomera (see Tindale 1965, MacFarlane 1978).

In order to stem the flow of Aborigines from the bush towards European centres and Alice Springs ration depots were set up at Haast Bluff in 1940 and Areyonga in 1942. The ready supply of food and water at these localities attracted large numbers of Aborigines and the depots themselves soon became overcrowded. To reduce the population pressure at these centres and to centralize the Aborigines scattered in small communities spread throughout the Reserve (which were apparently an eyesore to tourists (Nathan and Japanangka 1983, Downey 1980) the government set up new settlements at Amata in 1961 and Docker River in 1968. It is from the latter that the outstations described in this chapter have sprung.

Docker River itself was originally established as an outstation and, as described by Nathan and Djabanangka (1983:111) still looks very much like 'a large traditional camp with humpies scattered through the bush'. We were struck by the similarity in the appearance of Docker River and Kintore and would not be surprised if the pattern of growth and allocation of resources at Kintore parallels that of Docker River in its early years.

The homelands movement from Docker River began in 1976 - slightly later than the regions described so far in this report. In its early years the movement was very vigorous. The first two outstations (Tjuninanta and 


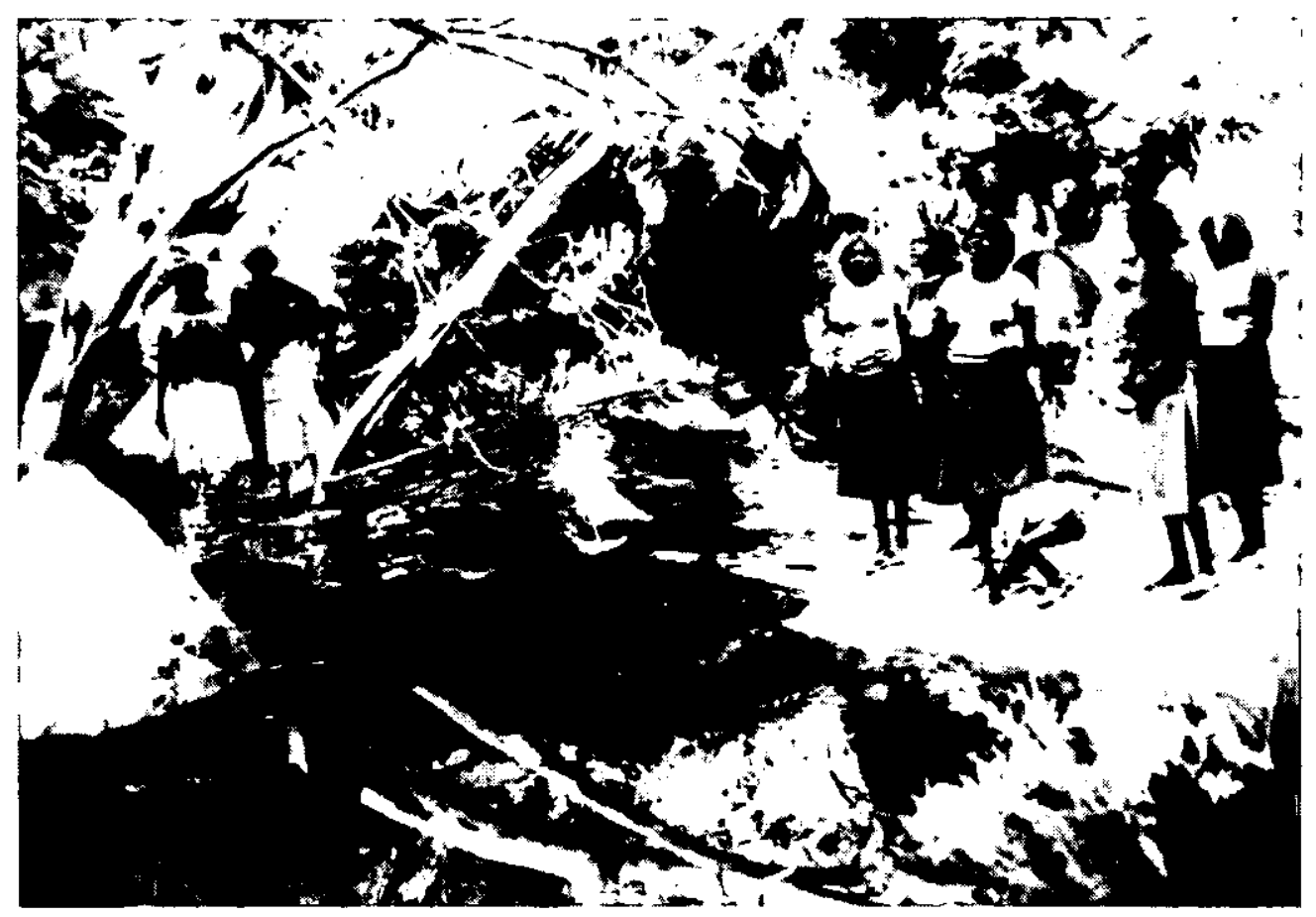

Plate 6.1 Kutjuntari waterhole

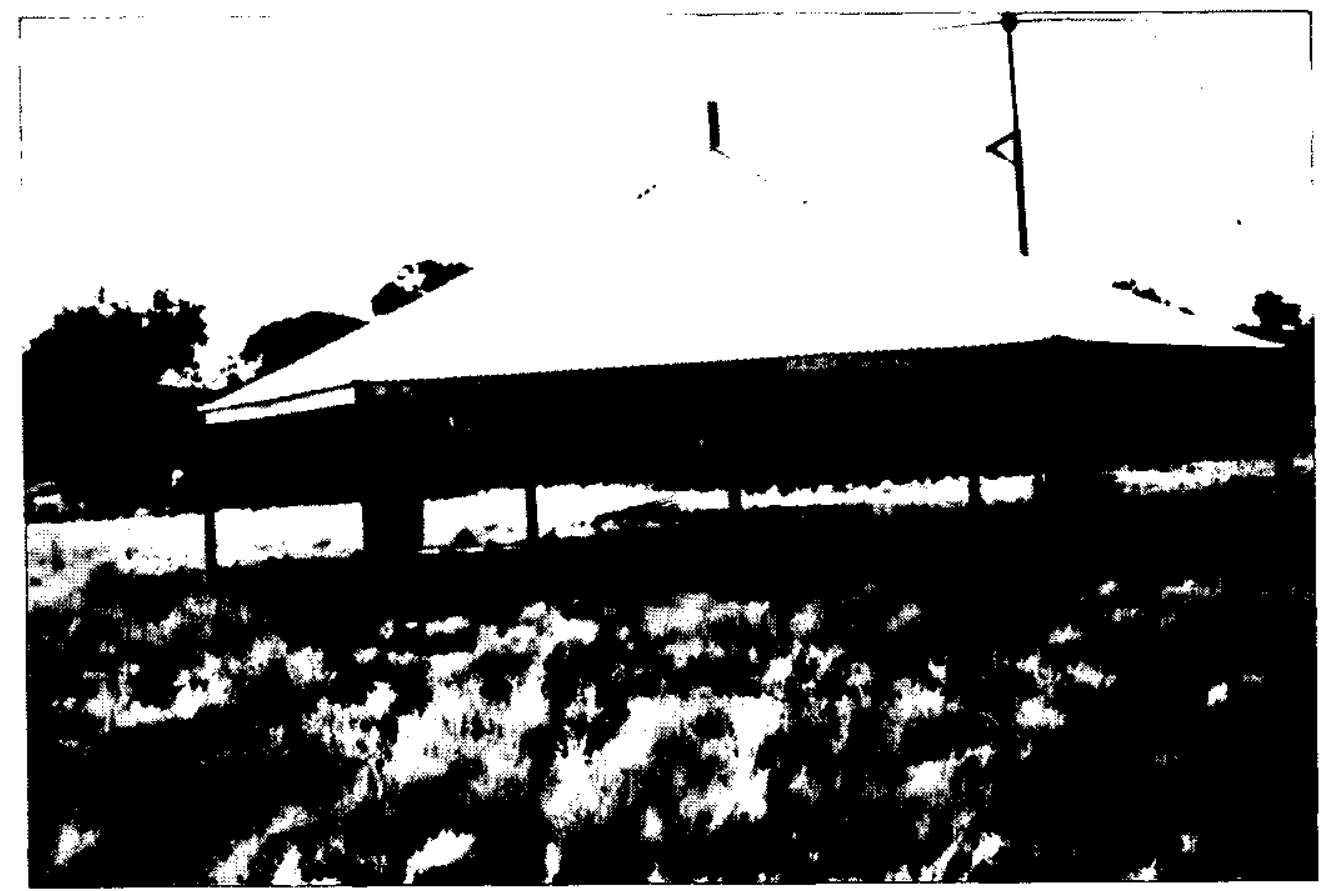

Plate 6.2 Open hexagonal house at Kunapula 
Puntitjarta), were quickly followed by four more (Tjukula, Puta Puta, Tjunti, Wangkari) and another five in 1978 (Kunapula, Walpakuka, Kutjuntari, Amputjutu, Kikingura). Since 1979 another two outstations were established (little Puta Puta, Walka) and one more was set up in 1980 (Warrapura). Ngangurr and Peutjara were set up in 1981 bringing the total number of outstations to 16. Eight of these were in permanent use, with a population of approximately 300 people (DAA file 78/630).

The population at outstations apparently remained remarkably constant throughout that period and people lived on outstations with minimal facilities. The people at Tjuninanta for example, lived at that outstation with no radio, house or vehicle and used to drink water from a soak dug into the nearby creek. Similarly the people at Wangkari had no facilities and once, in 1980, when an old woman was sick an old man and boy walked $40 \mathrm{~km}$ overland to Docker River to get assistance. The same situation was encountered at Puta Puta and Tjukula. Things were very tough and the 60-70 people living at the latter drank rain water which collected in a small hole blasted in a nearby exposure of limestone. In those early days there were many children at the outstations. A health sister from Docker River began regular visits delivering food and pension cheques, and a teacher visited some of the larger camps (this was apparently the first service of its $k$ ind in the Northern Territory).

No new outstations were begun in 1982 but by that year most of the other camps had been supplied with bores and some with houses, radios and vehicles. When visited that year by DAA all the camps were found, in contrast to previous years, to be abandoned (DAA file 78/630). The visit occurred in August and the reason given was that the Aborigines were afraid of being stranded by unseasonal rains!. In 1983 another six outstations were recorded by DAA (Karrukali, Petjalu, Kurkatingara, kulkula, Pilakatal, Pirrulpakalarintja) bringing the total number of outstations to 22 . Nathan and Djabananga (1983) visited nine of these camps and recorded a population of between 235-255 people. When we visited the region in July 1984 there were said to be more outstations (Kulang, Urilpila, Walu) but these in fact exist in name only. None of these or the earlier camps were occupied and appeared not to have been occupied for several months.

We visited 13 of these outstations (Amputjutu, Walka, Kunapula, Wangkari, Puta Puta, Petjalu, Tjunti, Karru Kali, Tjuninanta, Puntitjarta, Tjukula, Kutjuntari and Warrapura, Table 6.1). Among the remaining camps five (Pirrulpakarintja, Walu, Kulkula, Kulang, and Urilpila) were not visited because the Aborigines said they were not outstations just 'names only' or intended outstations. The remaining camps (Ngangurr, Pilkatal, Kurkatingara and little Puta Puta) were not visited because they were too far from Docker River (up to $250 \mathrm{~km}$ ) and the Aborigines did not want to make overnight camp necessary to visit them. Among those we did not visit we were told Ngangurr had a house and Kurkatingara had a bore and radio but no house or garden. At Pilakatal five unsuccessful bores had apparently been drilled for water. All the camps were unoccupied.

Location and Linguistic Affiliations

All the outstations visited in the Docker River region are mapped on Figure 6.1. Here it can be seen that nine of the camps are located between 20 and $80 \mathrm{~km}$ east of Docker River, generally along the road leading to Ayers Rock. Another six outstations are south of Docker River, more or less along the road to Kalka. On this road Amputjutu is the closest camp to Docker River $(13 \mathrm{~km})$ and Kurkatingara is the most distant $(65 \mathrm{~km})$. 


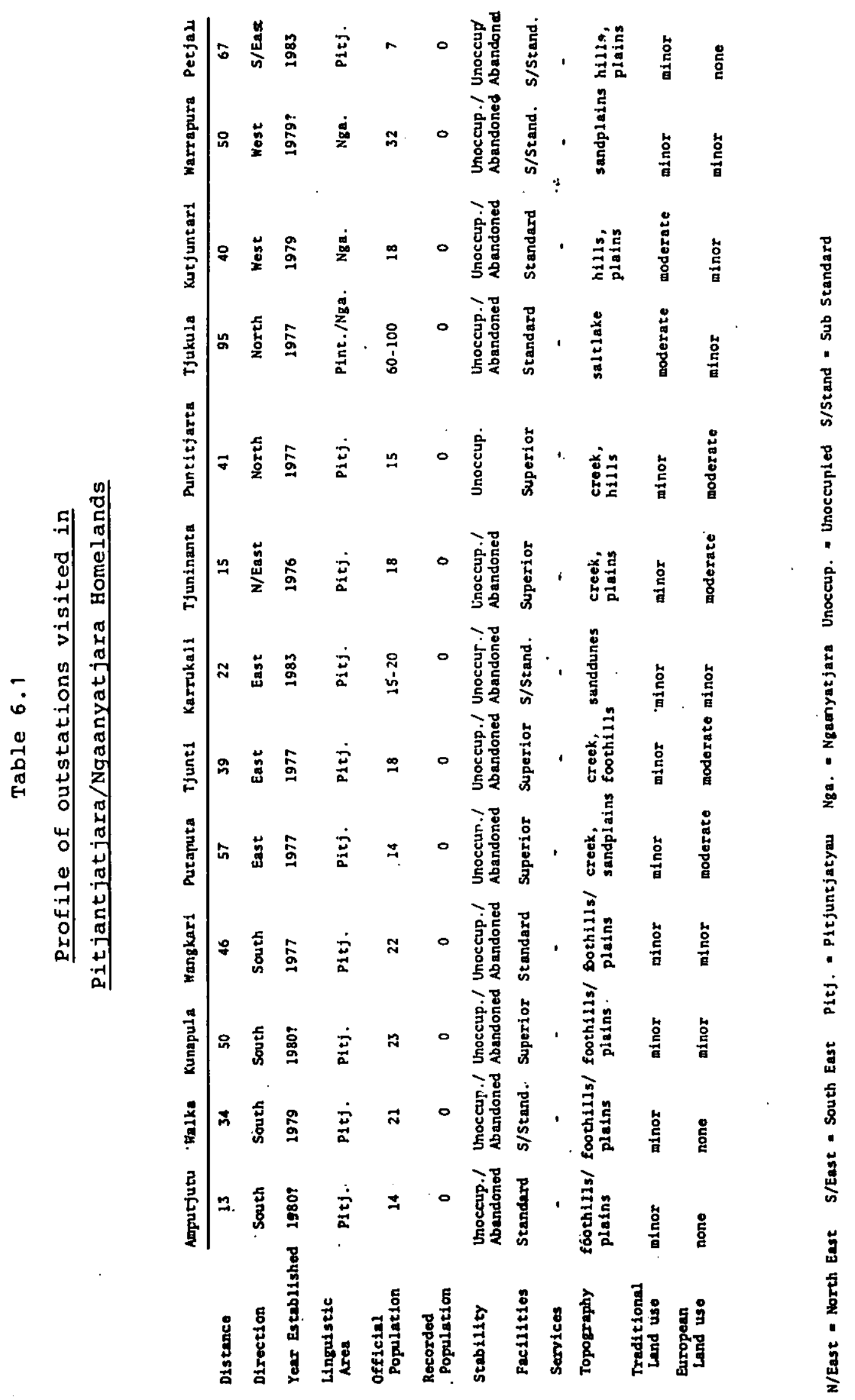


Figure 6.1

\section{Location map of outstations near Docker River}

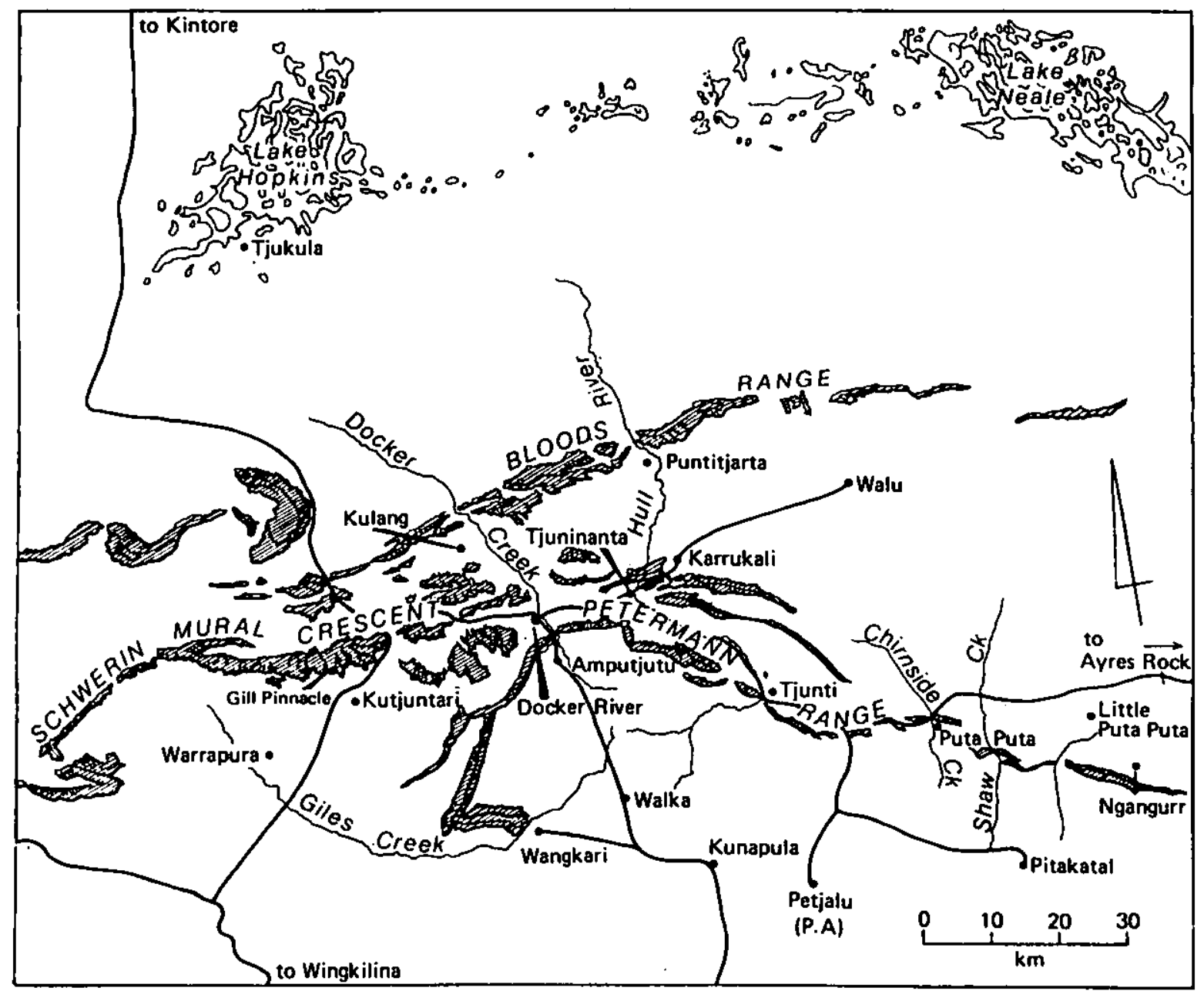


Four outstations are mapped north of Docker River. Two of these (Walu and Kulang) are not yet established and the other (Tjuninanta and Puntitjarta) are the oldest camps in the region. These two camps are 15 and $40 \mathrm{~km}$ north of Docker River respectively. The remaining outstations are located on the western side of Docker River. These are Tjukula and Kulkula (135 km north west and $250 \mathrm{~km}$ north west respectively) and Kutjuntari and Warrapura ( 40 and $50 \mathrm{~km}$ south west respectively).

Linguistically most of the outstations we visited are located in Pitjantjatjara country and owned by Pitjantjatjara people. These camps included Amputjutu, Walka, Wangkarri, Kunapula, Karrukali, Tjunti, Petjalu, Tjuninanta, Puntitjarta and Puta Puta. These are all located in the Petermann Ranges. Among the remaining three camps we visited Tjukula is owned by Pintupi people and is located in Pintupi/Ngaanyatjara 'mix up' (or shared) country extending from the Sherwin Mural Crescent to Lake Hopkins. Apparently Warrapura, south west of Gils Pinnacle is owned by Pitjantjatjara people but located in Ngaanyatjara country. Kutjuntari, east of Gils Pinnacle, is located in Ngaanyatjara country, owned by Ngaanyatjara people.

\section{Population}

Prior to beginning this project we were asked by several people if we were going to include Docker River in our study. We were told the outstation movement there was very interesting; the housing project was unique, the movement was active and the people highly committed. Given these expectations, our experiences in other regions and our knowledge of the history of the region we were surprised to discover that during our visit nobody was living at any of the 22 outstations recorded for the area; that five of those outstations existed in name only and that nobody appeared to have been at the 13 camps we visited for months. Several weeks prior to our visit $D C D$ also made a reconnaissance of the area and recorded more or less the same thing - that camps generally showed 'little or no evidence of permanent occupancy' (1984b).

Given the 'remarkably consistent' occupation of camps recorded in the early years of the homelands movement (DAA $78 / 630$, Nathan and Djabananga 1983:135) and the fortitude of the people living at the early camps we were puzzled over the reasons why the people no longer appear to be using the Docker River outstations. It is possible of course that the history of the Docker River outstations has been exaggerated and overstated and may have never been permenant; but given comments by Europeans who have been at Docker River a long time and early correspondence and notes from the Community Adviser during that era this does not seem likely. There is evidence that more recent reports of the movement have been a little over enthusiastic. In 1981, for example, European personnel claimed there were 16 outstations in the area whereas only eight of these were in fact in use $(78 / 630: 45)$. Today 22 outstations are documented yet $f$ ive of these are not in existence at all. Several possible explanations for the absence of people at camps present themselves, but unfortunately none are entirely satisfactory.

One of the obvious possibilities is that a high proportion of the outstations here have received ABTA toyotas and this has destabilised the population. This has occurred to a certain extent in other areas mentioned in this report but at the time of our visit the people were camped at Docker. River and were hardly using their vehicles at all. The simplest and easiest explanation for the apparent abandonment of camps was that the Docker River Community had been involved in an extended period of 
ceremonial business. However this is also unsatisfactory as we timed our trip several weeks after the 'business', thus giving the people time to return to their camps. This had not happened and when asked why, the Aborigines said they were waiting for payday before returning. The owner from Puntitjarta, for example, said his car was 'buggered up' and he needed money to fix it before he could get back. Others said they needed to buy stores and provisions. This does seem feasible except that the people did not in fact return to their camps. It was not until a DAA official came to Docker River a month later that people actually began to move back and one wonders if his presence did not have something to do with this. Local Europeans also did not believe the 'business' explanation. They said that 'the outstations were never lived in' and that the people live at Docker River all the time because of the greater conveniences. One European told us :

Once these places (outstations) were permanent but now people don't seem to be living in them. There used to be a permanent health sister visiting them, taking out food and pension cheques. Now people come in, like Tjukula, when the radio breaks down! There were more people living at outstations in 1976 than now. There are outstations blooming all over the place and no one at them. The old ones are the most frequently occupied. Almost, they are an excuse to get vehicles. No one goes out there unless they have a radio, house, bore and a vehicle. They want this and that.

There seems to our mind no need to decry the desire of the Aborigines for adequate facilities. In the example quoted, the fear of losing the radio by people from Tjukula is understandable as children died trying to walk from Tjukula to Docker River in 1980 and this may have been prevented if the camp had a radio then. However the major points being alluded to were that people are attracted to the conveniences of the settlements, that the outstations had lost their appeal and are reverting to holiday camps as the euphoria of returning to tribal country seems to be fading (see also Latz 1983:163). Clearly camps have remained unused for a long period, regardless of ceremonial business.

Several other reasons were also offered for the absence of people at the Docker River camps. One of these was that the Aborigines stayed at Docker River to watch video. Because of this the suggestion was made by a European (in all seriousness) that DAA should provide outstations with video machines if they want people to live on them! This seemed to us a most extraordinary suggestion and does little to strengthen the supposed notion of Aboriginal commitment to their country and sacred sites. We should also note here that Aborigines in Luritja Homelands had organized their own video nights at Mt. Liebig - thus the desire to watch videos in this region had not caused the entire homeland movement to collapse back to the main community.

We were also told outstations were too cold in winter but we found this hard to believe as Docker River is no warmer than its hinterland and there is in fact more firewood around outstations than near Docker River. Also in a comparable environment the people at Ernabella spend more time on outstations during the winter because Ernabella is too cold due to local wood shortages.

In several instances there were practical reasons for instability at camps but this does not account for the general destabalization of the 
movement. At Wankari, for example, the water supply at camp was too salty to drink. At Walka and Petjalu there was no water supply at all and people had to cart water in tanks and drums. At Karrukali the owner worked in the health clinic and thus had to be at Docker River all week. At Tjuninanta the owner moved to Docker River to care for sacred boards taken to the settlement following the discovery of tourists' footprints at their hiding place near his camps.

Apart from these specific instances however, we were particularly puzzled by the general destabilization of the homelands movement. We were not in the region long enough to really come to grips with the real causes for this but felt reasons such as ceremonial, business, toyotas, videos and cold weather were inadequate.

There was however, a final factor which we felt may have some bearing on the apparent destabilization of the homelands movement in this area. Although based mostly on intuition it was our suspicion that the outstation movement around Docker River was being ' $k$ illed of $f$ ' by too much European involvement. At Docker River the outstation service staff consisted of an adviser, gardener, builder and mechanic. This compared to the presence of only one outstation co-ordinator at each of the homeland areas around Ernabella, Papunya and Yuendumu and the total absence of official outstation staff at Kintore. In these areas the Aborigines were largely responsible for the planning and direction of the homelands movement. At Docker River however, it seemed Europeans filled much of that role. It was obvious, for example, that they were entirely responsible for the design and construction of houses, reticulation, fencing, gardens and other outstation developments. Thus we were left wondering whether the outstation movement from Docker River had not been 'taken over' by Europeans and if the Aborigines had not withdrawn in the face of increasing European participation in the movement. The European staff at Docker River struck us as being highly concerned with and committed to Aboriginal welfare; but perhaps to the point where Aboriginal initiative was being stifled by their enthusiasm and motivation. We wondered therefore whether the well meant objectives of the Europeans had not outstripped the fundamental aspirations of the Aboriginal people who began the movement. We wondered if the Aborigines did not feel they had simply moved from one form of European control and administration into another and had thus detached themselves from the movement because of this.

Housing

Unlike other regions in the Western Desert the houses constructed in in the Pitjantjatjara/Ngaanyatjara Homelands consist of large hexagonal shaped open shelters supported by steel girders welded to car wheel rims set in the ground (plate 6.2). The construction of these open frames and roofs was apparently meant to provide stimulus for the Aborigines to construct rock walls either around the circumference of the hexagon or from the centre to the external edge, thus making a private triangular shaped room. To date some walls have been started at kunapula and the builder was making walls at Tjunti. The Aborigines however did not seem very enthusiastic about building walls around the houses and said they only used the housing for shelter during rain and for ventilated shade during the hot season. At Puntitjarta the Aborigines had built a humpy inside one of the hexagonal shelters (Plate 6.7)! Our impression of these houses was that they were not suited to the outstation situation. In their uncompleted state they do not provide as effective shelter and storage as the first stage houses used in the Luritja, Pintupi and Walpiri Homelands. We would 
be surprised if the Aborigines ever complete the houses and we imagine it would be expensive for builders to do this.

These hexagonal shelters cost approximately $\$ 16000$ in their first stage and so far 13 have been constructed and another two are in the process of construction. Each of these camps could have had four first stage houses of the kind described earlier in this report for the cost of each of these hexagons. At present the hexagons are functioning as no more than an extravagant form of shelter for two way radios and the Aborigines are still camping in humpies, windbreaks and galvanized iron sheds around them. We recorded three galvanized iron shacks at Kunapula, two shacks at Wangkari, three shacks at Puta Puta, tents and humpies at Petjalu, five sleeping fires in the spinifex at Karrukali, two humpies and a double shed' at Tjuninanta, one shack and one 'double shed' at Puntitjarta, six humpies and shacks at Tjukula, several humpies and three shacks at Kutjantari and four humpies at Warrapura.

The 'double sheds' mentioned above consist of two large parallel galvanized sheds placed about $4 \mathrm{~m}$ apart, with a roof over the space between each shed. These are rather ugly buildings but in many respects are a good design. They offer shelter from wind and rain, storage facilities and incorporate the main advantage of the hexagon - ventilated shade during the hot season. An improved version of this basic design is being used at outstations around Utopia. Here two small galvanized sheds have been placed in diagonal corners under a large galvanized iron roof. These offer the same basic facilities for storage and shelter - but also have a large well shaded sitting area wich is open to breezes. One drawback of this design is that people tend to urinate against the walls in the sitting area and thus they often smell rather unpleasantly.

\section{Water}

All the camps we visited except Petjalu, Karrukali and Walka had been equipped with underground water bores. At Petjalu and Karrukali water is transported in 44 gallon drums. There is also a small soak at Petjalu. The people at Walka cart water in a mobile water tank. They also have a rain water tank and have built a small dam to catch runoff. Among the rest, five camps (Amputjutu, Kunapula, Wangkari, Kutjuntari and Warrapura) have been equipped with hand pumps and the remainder (Puta Puta, Tjunti, Puntitjarta, Tjuninanta and Tjukula) have been equipped with windmilis, tanks and some reticulation to camps and gardens. Water was also obtained from a rain water tank and rockhole at Wangkari and a small soak at Kunapula.

At Kutjuntari the hand pump was a long way from the camp and at Warrapura the water tasted terrible. A new bore had been sunk $1 \mathrm{~km}$ east of the camp but this was not yet equipped. Many of the camps around Docker River suffered the same chronic problem of poor water quality. At some camps it has been difficult to find water at all. For example, five bores had to be drilled at both Pitakatal and at Amputjutu. Three bores were drilled at Walka but no water found. Two bores each were drilled at Djukula, Kunapula, Walka and Tjunti. Unfortunately we could only get data for seven camps in the region yet all these had poor water. The worst camps were; Wangkari - very high salt content $(13400 \mathrm{mg} / \mathrm{l})$; Amputjutu - high in fluoride $(2.5 \mathrm{mg} / 1)$, dissolved solids $(18990 \mathrm{mg} / 1)$, sodium chloride (1300) and very hard (630): Kunapula - high fluoride $(2.5 \mathrm{mg} / 1$ ) and iron ( 3 mg/1); Puntitjarta and Puta Puta - above the acceptable level of fluoride $(2.5$ and $2.2 \mathrm{mg} / 1$ respectively) (Figure 6.2$)$. 
Figure 6.2

Water quality of camps near Docker River

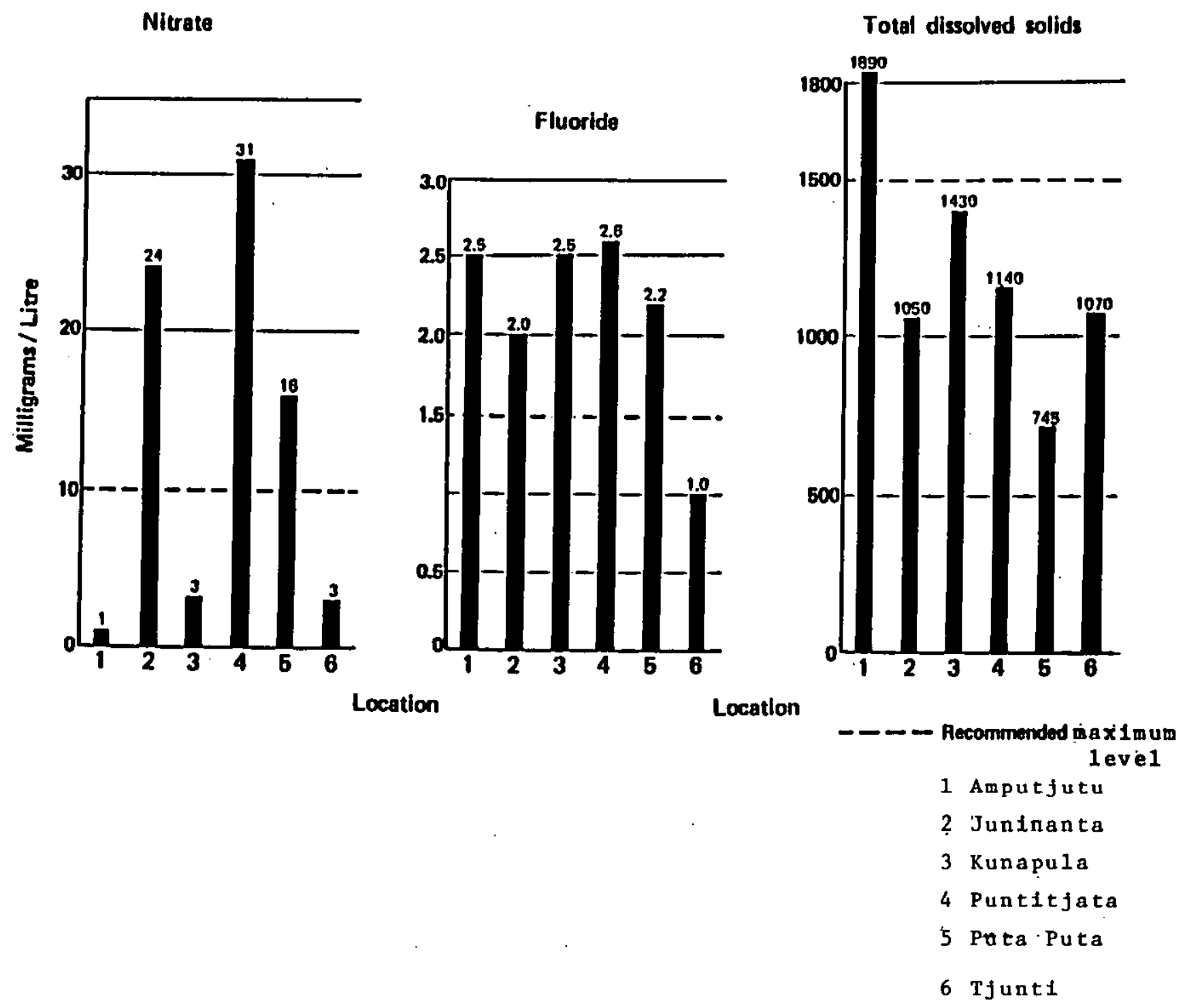


Radio Phones ('radios') and Toyotas

In comparison with other homeland regions so far described the Pitjantjatjara/Ngaanyatjara homelands are relatively well supplied with radios and toyotas. For example all of the 13 camps we visited had been supplied with solar powered two way radios and 11 of the camps had toyotas supplied by ABTA funds. Two camps without toyotas were Warrapura and Petjalu. Among the other camps Tjukula have a truck and toyota but both are in disrepair. The toyotas supplied to Puntitjarta, Rutjuntari have also broken down. An unusually high proportion of Docker River outstations had toyotas and the point was made to us, as in other areas that many of the outstations were set up simply to obtain ABTA funds for toyotas. The same view is expressed at camps in other regions (see Chp.4) and here as in these other regions we have no evidence to confirm or deny this suspicion.

Miscellaneous Equipment

Various pieces of equipment were recorded at several outstations, although as the camps were unoccupied it was difficult to ascertain what gear was in use at individual camps. We did notice that most camps had been supplied with rakes, hammers, saws, PVC piping and fencing materials. Some camps (Amputjutu, Wangkari and Kunapula) also had manually operated washing machines. At Tjunti we recorded hoses and sprinklers and there was also a diesel pump on their bore. An air strip had been graded at Tjukula.

\section{Services}

No services are supplied to any outstation from Docker River. People living in the bush must go to the settlement to get health care, food and education. In the eariy years when the outstations were more active and stable a health sister used to visit camps weekly and deliver food and pension cheques. A teacher also used to visit Tjukula, where there were said to be a large group of children. This was apparently the first outstation teacher employed in the Northern Territory.

Topography

$\underline{\text { Landscape }}$ and Land Use

The landscape in the Docker River region is among the most magnificant in Central Australia (Plate 6.3). Steep escarpments hang onto rugged sunburnt mountains and these fall away to expanses of open woodland resembling the African savannah. The Petermann Ranges form the core of the Ngaanyatjara/Pitjantjatjara Homelands and run east into the Schwerin Mural Crescent near Rutjuntari and Warrapura. These mountains are cut by six large creeks of which Docker River is the largest. Alluvial plains are extensive in and around the hills and are often broken up by rocky ground, ridges and granite domes. An arm of flat spinifex sandplain occupies the eastern corner of the homelands and to the north there is an extensive area of sand dunes. These run more or less east west between the Petermann Ranges and a series of salt lakes across the north of the region. The largest of these salt lakes are Lake Hopkins and Lake Neale (Table 6.2).

Climate

The nearest climatic data for the Docker River region comes from Giles; $80 \mathrm{~km}$ to the west. This homeland region experiences a similar climatic pattern as its northern neighbour with hot summers and cold winters 


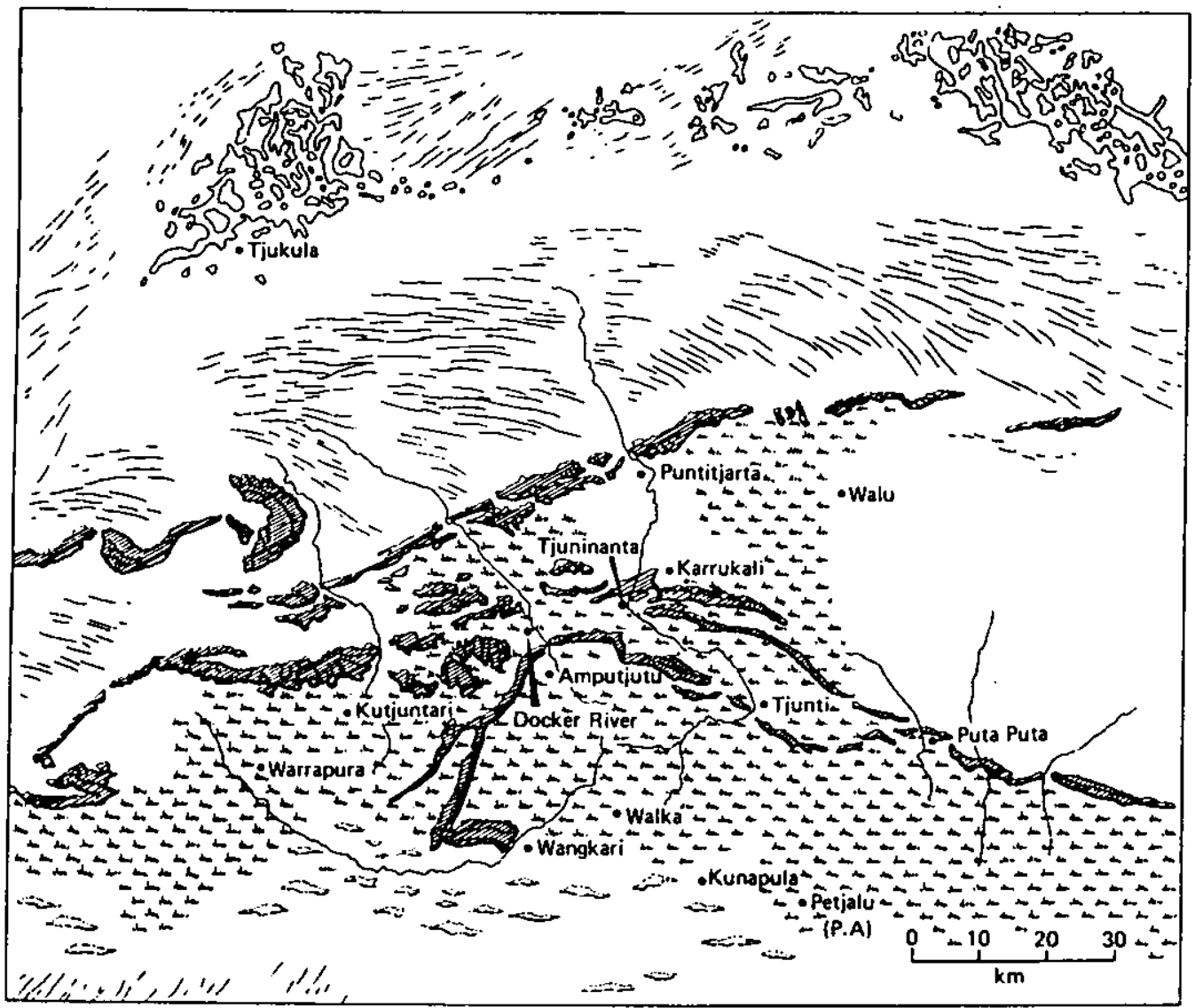

\begin{tabular}{|c|c|c|c|c|c|c|}
\hline UNIT & AREA & LANDFORM & SOIL & VEGETATION & TAADITIONAL & EUROPEAN \\
\hline & large & $\begin{array}{l}\text { Sand dunes: closely spaced } \\
\text { paraliel and irregular dunes } \\
\text { runing E.W and S.W.N.E. } \\
\text { minor areas of mobile sand. }\end{array}$ & $\begin{array}{l}\text { Red dune sand and } \\
\text { red clayey soils. }\end{array}$ & $\begin{array}{l}\text { Sparse shrubs and low trees. } \\
\text { Desert oak (Casuarina decais. } \\
\text { neans), bloodwoods } \\
\text { (Eucalyptus terminalis) and } \\
\text { Spinifex (T. basedowii and } \\
\text { Plectrachne schnizin). }\end{array}$ & $\begin{array}{l}\text { Reptiles, wood. } \\
\text { fruit, nectar. }\end{array}$ & None. \\
\hline & medium & $\begin{array}{l}\text { Rugged hills, fringed with } \\
\text { alluvial fans merging into } \\
\text { broad alluvial vallies. Large } \\
\text { creeks and flood plains. }\end{array}$ & $\begin{array}{l}\text { Shallow rocky soils } \\
\text { on hills. Alluvial } \\
\text { soils and clayey } \\
\text { sands on plains and } \\
\text { alluvial fans. }\end{array}$ & $\begin{array}{l}\text { Sparse on hills: grass lands and } \\
\text { open woodland with mulga } \\
\text { (A. aneura), witchetty bush } \\
\text { A. kempeans). Cassia spp. } \\
\text { Red gums (E. camsidulensis) } \\
\text { along creeks. }\end{array}$ & $\begin{array}{l}\text { Large game. } \\
\text { rabbits, edible } \\
\text { grubs, wood for } \\
\text { implements and } \\
\text { fire. Edible fruits. } \\
\text { waterholes. }\end{array}$ & $\begin{array}{l}\text { None - plains } \\
\text { present reasonable } \\
\text { grazing pastures. }\end{array}$ \\
\hline & medium & $\begin{array}{l}\text { Alluvial plains with occasional } \\
\text { granite domes, ridges and } \\
\text { sand dunes. }\end{array}$ & Clayey sand. & $\begin{array}{l}\text { Spinifex (T. busedowii) grasses } \\
\text { and open woodiand with mulga } \\
\text { (A. eneura), witchetty bush } \\
\text { (A. kempeans). tronwood } \\
\text { (A. estrophiolata). Hakes spo. }\end{array}$ & As above. & $\begin{array}{l}\text { As above, some } \\
\text { gardening on } \\
\text { plains. }\end{array}$ \\
\hline & medium & $\begin{array}{l}\text { Sandplains: flat, gently } \\
\text { undulating plains, few dunes, } \\
\text { little drainsog. }\end{array}$ & Red sand. & $\begin{array}{l}\text { Shrub steppe: spinilex } \\
\text { ( } T \text {. bosdowii and } T \text {. pungens). } \\
\text { and scattered shrubs (Hakas, } \\
\text { Grovilles, Acecis and } \\
\text { Eucatyptus). }\end{array}$ & $\begin{array}{l}\text { Feptiles, wood } \\
\text { fruits and noctars. }\end{array}$ & None. \\
\hline & modium & $\begin{array}{l}\text { Pugped granite hills, quartzite } \\
\text { and sundstone ridges and escarp } \\
\text { ments, Steep vallies encised by } \\
\text { large croeks. }\end{array}$ & Shallow rocky soils. & $\begin{array}{l}\text { Sparse shrub and mixed or asses. } \\
\text { Triodis cletandii, scattered } \\
\text { Acacis, Cessia and Eremophilis } \\
\text { spp. }\end{array}$ & $\begin{array}{l}\text { Wild fruits. } \\
\text { tobacco, water- } \\
\text { holes, some } \\
\text { hunting }\end{array}$ & None. \\
\hline & Iminor & Salt takes. & Water logged clays. & $\begin{array}{l}\text { Unvegetated: samphire, } \\
\text { Molalouca on fringes. }\end{array}$ & $\begin{array}{l}\text { Some waterholes. } \\
\text { rabbits hunted. }\end{array}$ & None. \\
\hline
\end{tabular}

Table 6.2 Land Summary of Docker River Region 
Figure 6.3

Mean rainfall and temperature profiles at Giles

Temperature

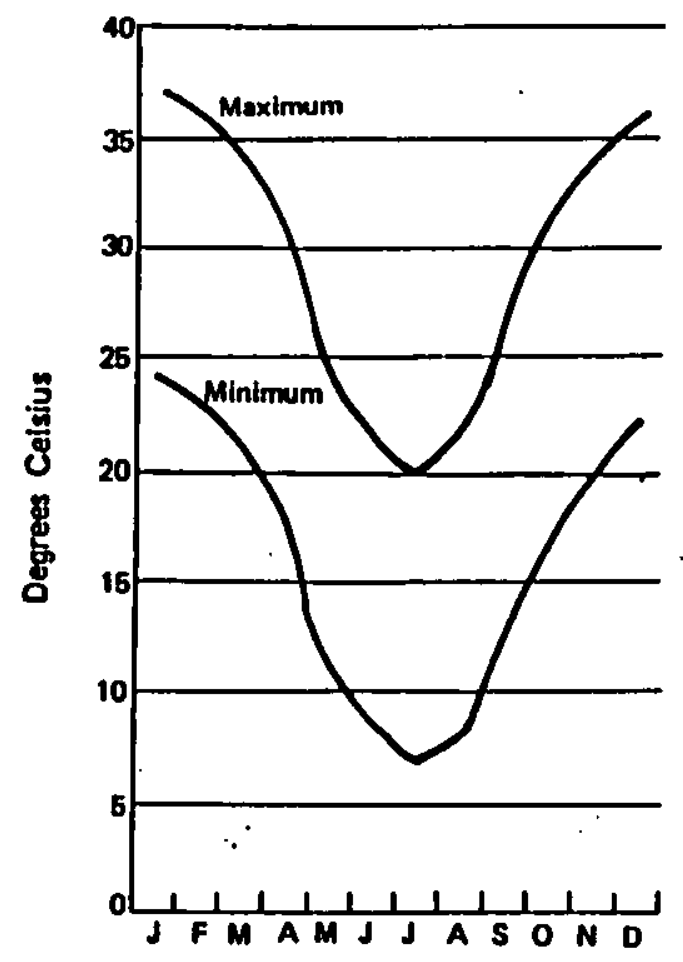

Rainfall

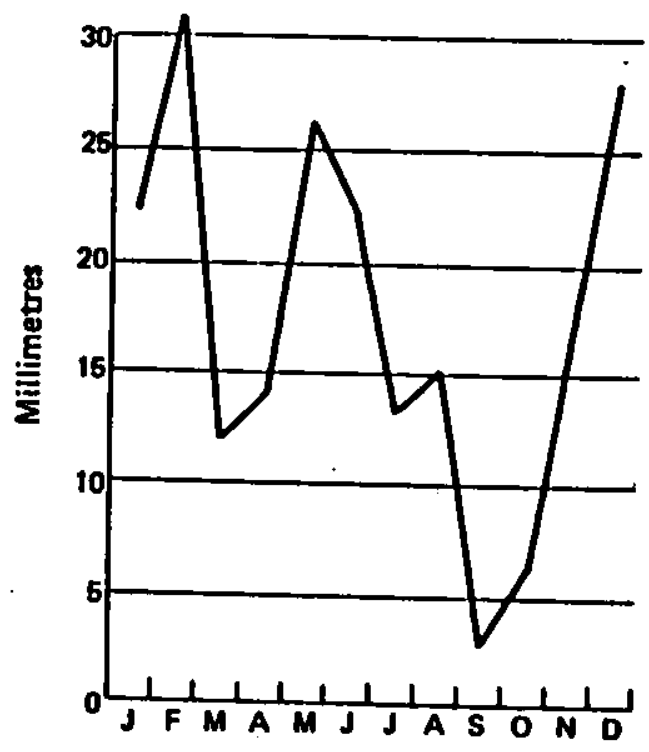


although the Docker River area receives much more pronounced winter rains (Fig. 6.3). Winter temperatures are also slightly lower; ranging between an average of seven and 17 degrees Celsius during the night and 20 to 30 degrees Celsius during the day. There are occasional frosts and the minimum temperature recorded at Giles is -8 degrees Celsius. This is the same as the minimum temperature recorded for Canberra and gives some idea how cold the desert winter can be. Winter rain comes from low pressure systems extending north to the Petermann Range from southern Australia. Winter rainfalls are heaviest in early winter (May, June) but decrease into the dry season during spring. September is the driest month. Summers are hot with occasional humidity. Temperatures range between an average of 32 and 37 degrees Celsius during the day and between 20 and 25 degrees Celsius at night. Rainfall is generally erratic delivered by tropical low pressure systems and highest during the summer months (December to February). The average annual rainfall total for this region is just over $200 \mathrm{~mm} /$ year and evaporation is very high (Hall et al. 1981).

\section{Vegetation}

The largest botanical zone in the region is the sand dune country in the northern portion of the homelands region. Here the plant life is predominantly spinifex with hard spinifex common on the swales between dunes and a feathery topped species common on dune flanks. The deeper sand in this landscape also supports scattered shrubs bloodwood, mallees, desert oak, honeysuckle and quandong. Similar shrubs grow on the sandplain with acacia species, scattered snappy gums and ghost gums.

The vegetation on the alluvial plains is mostly low open woodland. Here dominant species include mulga, witchetty bush, Cassia spp., grasses, and forbs (Heliseterum spp.). Red gums and coolibahs grow on creeks and flood channels through the plains. There is very little vegetation on the hills. Common species include spinifex (T. clelandii) and various species of Acacia, Eremophlia and Cassia.

Vegetation associated with the salt lakes includes various species of samphire, spinifex and melaleuca. There are extensive areas of.dead finish (Acacia tetragonophylla) growing on calcareous sandplains around Lake Hopkins.

\section{Plants of Economic Importance}

The outstations in the country around Docker River have access to some of the vegetable foods found in the northern homelands but, generally the open woodland country most abundant in the area is more suited to hunting than collecting vegetable foods. As a consequence only a few wild vegetables are collected and most of the carbohydrate consumed is brought from stores.

We use white fella mirka (vegetable food). Don't get bush tucker. Young people don't know. Young people can't know. Wangkanyu (grass seed) before. old people using, we don't know. Don't eat mirka; olden time. Can get quandong and other one same (bush plum). Also get yili (wild fig).

These vegetables as well as bush tomatoes, (particularly solanum centrale) and bush onions are still readily collected in the region. They are easily gathered and can be eaten with little or no processing. Wild 


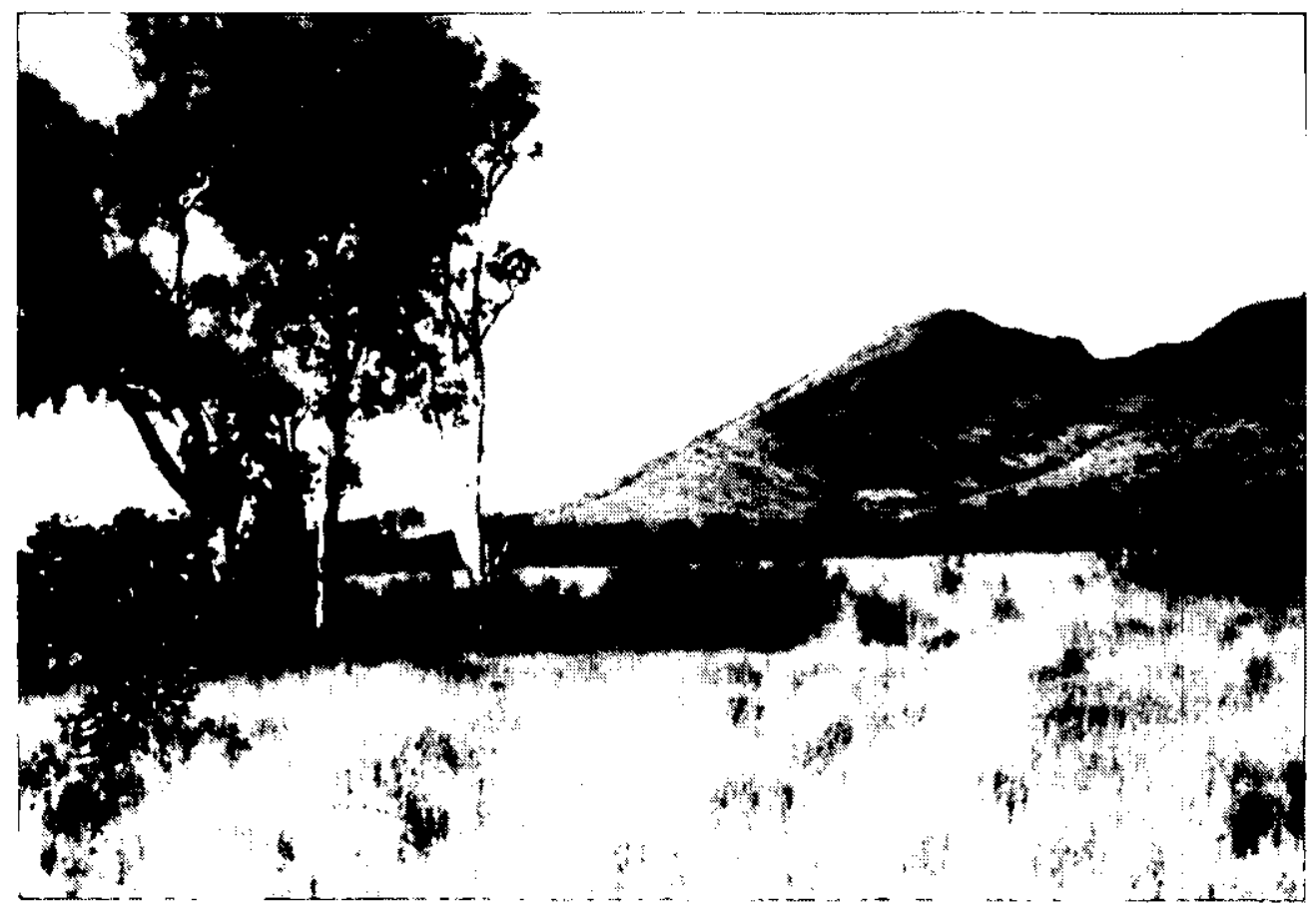

Plate 6.3 Petermann Ranges near Docker River

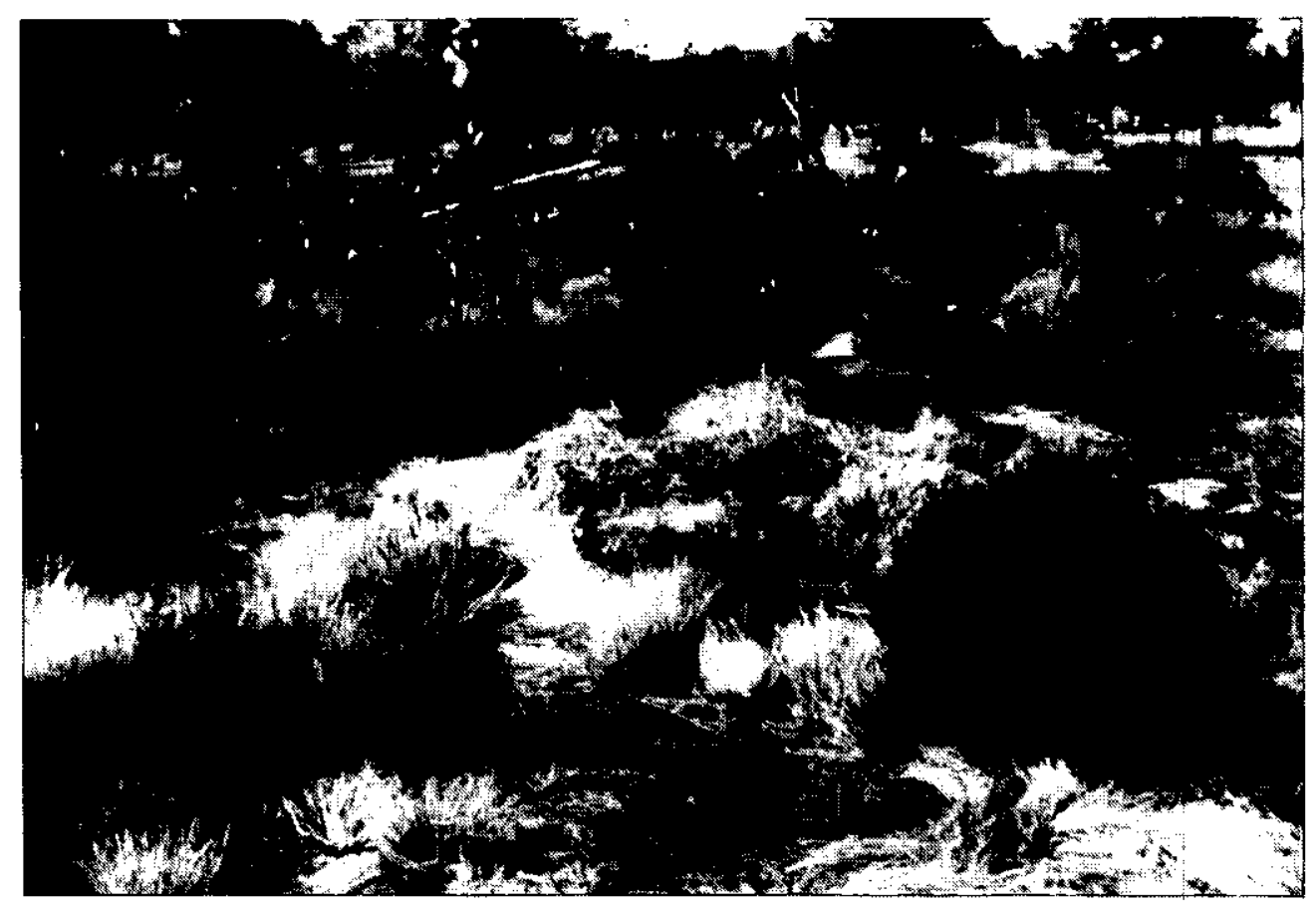

Plate 6.4 Trellised grapes growing in the garden at Puta Puta 
figs are very abundant in the hills and quandong and bush plums are common on the alluvial plains and along creek banks. Bush onions also grow in creeks and areas which get flooded and bush tomatoes grow everywhere along road cuttings, at camps, in overgrown gardens as well as on alluvial plains and sandplains. Other vegetable foods which have remained important in this region are native tobacco, which grows in rocky crevices; mulga sap, which is exuded in winter; coconut apples, which grow on bloodwoods and bush bananas which are available through winter.

Several of the native hardwoods are still used for making wooden implements. Most commonly used is mulga. This is used for making various implements for personal use, trade and sale through tourist outlets (boomerangs, shields, punishment spears, clubs, spear throwers) and other woods such as dogwood, iron wood, coolibah and bloodwood are used for making boomerangs, clubs and wooden dishes. These hardwoods, as well as desert oak are used for building and firewood. Wood is abundant in the region and mulga, the most valuable, is particularly abundant. Another wood which is still important in the region is pandorea doratoxylon found in the hills. This wood is very light and used for making the shafts of hunting spears (see Gould 1970). Traditional adhesives made from spinifex resin is still commonly used in the region as a hafting and repairing agent on dishes, spear throwers and spears.

Animals

Animals are the main component of the bush foods actively used today. The large animals such as kangaroo, euro, emu and bustards are most frequently hunted, although the Aborigines said the population of bustards (bush turkeys) in the region is not very large. People appeared not to be very enthusiastic about collecting goannas. In fact only the more traditional Pintupi and Ngaanyatjara people from Tjukula and Kutjuntari showed any interest in them at all. Rabbits are extremely abundant in the region and have devastated large areas of the mulga plains. These are hunted enthusiastically with rifles during the day and on moonlit nights. Women dig for rabbits using the same technique once used for hunting bandicoots. Two other traditional foods still collected avidly are.honey ants and witchetty grubs. Both are widespread in the region.

Camps and Land Use

With the exception of Tjukula all the camps visited were located on alluvial plains nestled among the hills. This is relatively fertile country and, unlike the salt marshes and sandplains surrounding Tjukula, is abundantly supplied with water and is particularly good country for hunting and gathering witchetty grubs.

Unfortunately, however, because none of the camps we visited were occupied our observations of traditional land use practices for this region are rather limited. We did not have the opportunity to camp at outstations, and thus talk to people living there or to observe the range of freshly accumulated debris at camps. Because of this our comments on the nature of traditional land use are largely generalised and impressionistic.

In the previous section we outlined the most important of the foods still hunted and collected by people today. At the camps themselves the only evidence we saw of the traditional use of local resources consisted of three earth ovens for baking kangaroo at Wangkari, Kutjuntari and Petjalu; holes where people had been digging bush onion at Petjalu and Tjukula; and 


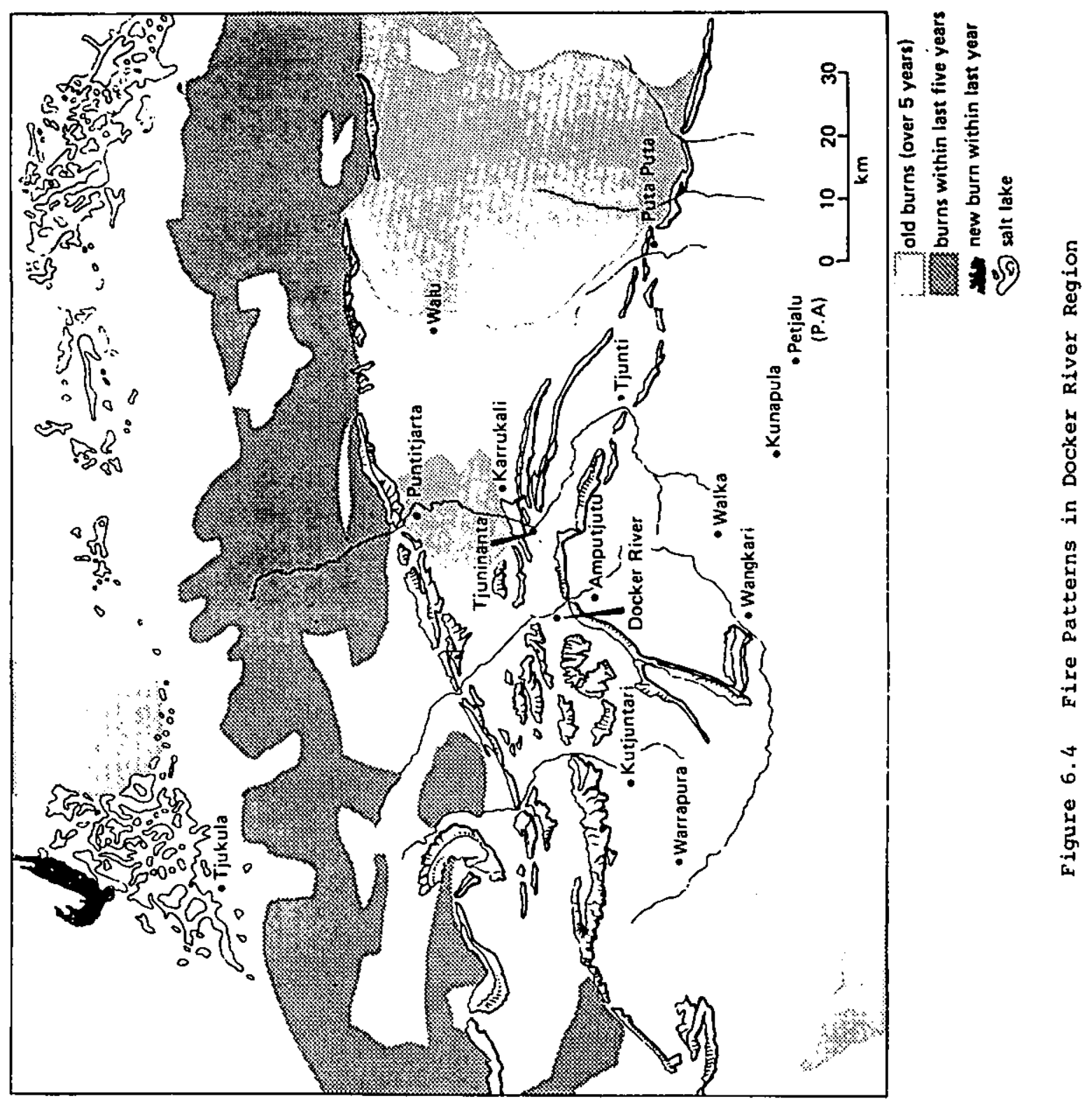


several thrusting spears and clubs cut from Hakea saplings and left at Puntitjarta. The people showed surprisingly little enthusiasm for bush food and the only bush tucker collected by people who travelled with us included a python, collected by pintupi people at Tjukula; one goanna collected by Ngaanyatjara people, at kutjantari; one kangaroo and five rabbits at Wangkari and some mulga lerps (sap) near Puntitjarta collected by different Pitjantjatjara men. All of the Aboriginal people we spoke to confirmed that store food is most popular at outstations and this certainly reflected itself not only in our limited observations, but in the limited extent to which the countryside around the outstations has been burnt. In fact the only areas where we noted areas of 'burn grass' was on the road to Petjalu and between Tjuninanta and Puntitjarta. Furthermore people showed no inclination to burn the country even though we often travelled through large stretches of country where the spinifex was very thick and high and clearly had not been burnt for a long time. The absence of fire associated with the outstation movement in this homeland region generally is confirmed by looking at satellite imagery for the region. Figure 6.4 is redrawn from a photograph taken in October 1983. In this figure one can see the lack of correlation between location of camps and areas of burnt country. There is evidence of an old fire in the area between Tjuninanta and Puntitjarta probably burnt when these camps were first established. There is also a large recent fire across the centre of the region, but its distance from any outstation suggests it is the result of a large wild fire rather than specific attempts to revitalise the country as the outstation movement has developed.

This general situation contrasts with our impression of the extent of traditional land use and land management practices at camps in the Pintupi, Luritja and Walpiri Homelands. The reasons for this difference in land management practices are obscure but it is our suspicion that the people living around Docker River are further removed from the traditional methods of bush subsistence. Our impression is that the Aborigines have become more dependent on European food over a longer and more consistent European contact and thus have lost the taste and/or skills necessary to process some of the bush foods still used by the northern western Desert Aborigines. We observed that the process of change is even more. marked at outstations in the vicinity of Ernabella (see chapter 7).

\section{Gardens}

\section{European Land Use}

All but three of the outstations we visited (Amputjutu, Walka and Petjalu) had moderately large gardens. These consisted of rectangular areas of cleared ground about $25 \mathrm{~m} \times 25 \mathrm{~m}$ in size and enclosed with $2 \mathrm{~m}$ weld mesh fences and watered by trickle and drip irrigation techniques.

The earliest gardens in the region were apparently planted in 1980 at Tjunti, Tjuninanta and Puntitjarta. Since then a botanist has been employed to foster horticultural developments at these and other camps and establish a homeland nursery at Docker River.

During out visit the most productive gardens observed were at Puta Puta, Tjunti and Puntitjarta. At Puta Puta the garden appeared reasonably healthy and well maintained (Plate 6.4). It contained small numbers of grapes, figs, watermelons, lemon and orange trees, pumpkins and passion fruit. The garden was shaded and protected from the wind by a deciduous climber (chinese lantern) growing on the fence and strategically placed tressles. Watermelon were ripening at this garden but birds had pecked the 


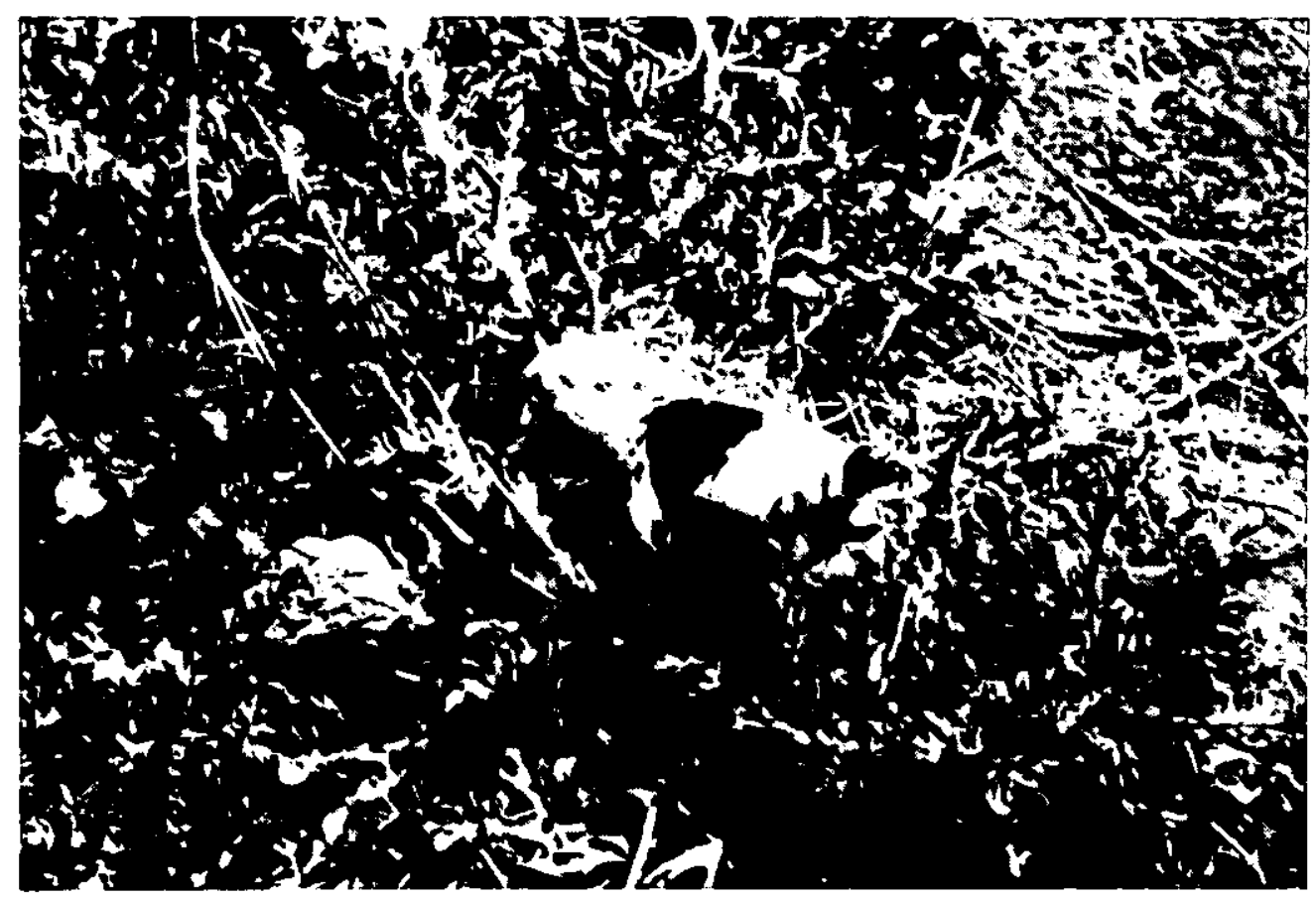

Plate 6.5 Pecked vegetable at Puta Puta

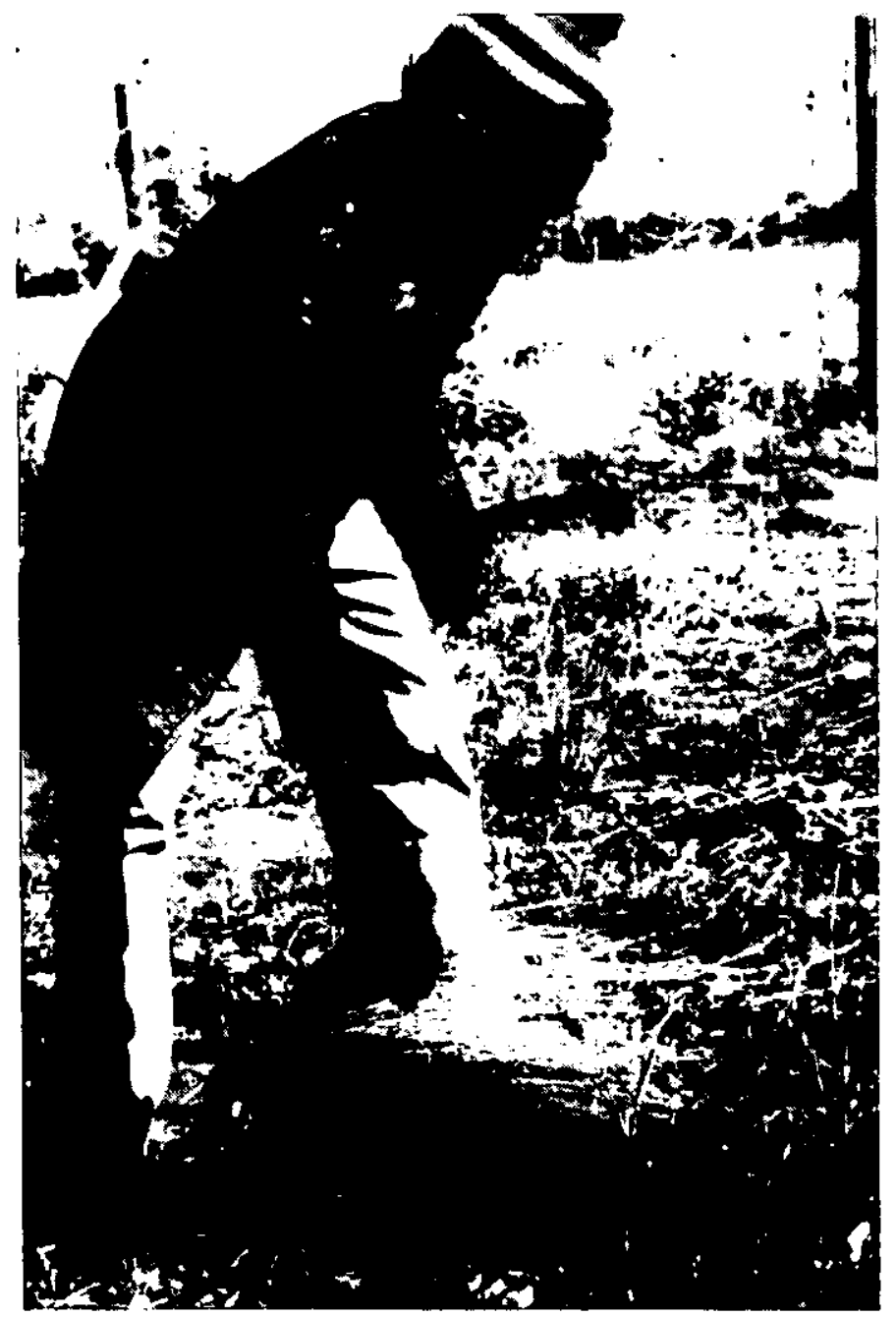

Plate 6.6

Hiding watermelons from birds at Puntitjarta 
flesh out of most of the fruit (Plate 6.5). This was a common problem with all the gardens we saw in this region. The garden at Tjunti also appeared quite healthy and had been recently planted with carrots and peas. Plants which were established at the garden included orange trees, figs, grapes, a large mulberry tree and seven year beans. Shade was again provided by chinese lantern and large white cedar trees. The best garden in the region was at Puntitjarta and the owner of this camp appeared to be the most genuinely interested gardener living at any of the outstations. His garden contained watermelons, pumpkins, figs, large mulberry trees, seven year beans and green beans. His watermelon patch was relatively successful although he also faced a continual battle against birds. To protect the watermelons he had covered them with grass, cloth, galvanised iron and anything else he could find (Plate 6.6). This provided effective protection but seemed to slow the ripening process of each fruit. Five of his watermelons were surviving in this way and last year he sold one in the Docker River store. The melon was said to have fetched $\$ 5.00$ and was the talk of the settlement, even though the customer later complained that the melon had not been ripe. There was also a large pumpkin patch at Puntitjarta which appeared to be thriving. This was located beside the windmill tank and was watered by spillage and overflow from the tank. The patch was very large (Plate 6.7) and had many flowers and fruit.

The gardens at the remaining camps were not as successful as at these three camps. Tjuninanta appears to have once had a good garden, containing watermelons, pumpkins, zucchinis, mulberries, figs, dates, grapes and seven year beans. Now, however, all the melons have been pecked out by birds, the pumpkins and zucchinis are all dried up and the garden is badly overgrown with prickles, grass and bush tomatoes. There also appears to have been a substantial garden at Tjukula and we could still recognise the remains of beans, peas, watermelons and sweet corn. However the garden had not been watered for months, the birds had destroyed the watermelon, rabbits had devastated the beans and the perspex pipe for watering the garden was cracked and punctured and the thread on the tap was damaged and would not stay on. At the other camps the gardens were an absolute disaster. Some of these had only been planted in 1983 but a combination of lack of water, birds and rabbits had left them bare. At Kutjuntari and Warrapura for example, there was nothing left of the gardens except the fences, PvC piping and depressions in the ground where plants had once been put (Plate 6.8). The same situation was encountered at Kunapula and Wangkari although at Karrukali four orange trees had been planted and they still looked to be alive.

Reflecting upon the garden exercises at the Docker River outstations several things are apparent. Most obvious is that despite the skills and enthusiasm of the horticultural adviser the exercise has not been an overwhelming success. There are several reasons for this. One of course is the physical hardships of the region - soils are often thin, gravelly and infertile. The environment is subject to climatic extremes - hot summers, freezing winters, droughts and floods. There are also problems with wind and rabbits, birds and the water quality is often poor. At Wangkari for example the water has a very high salt content and at Kunapula the water is rather alkaline.

However there are also other factors which are of fundamental importance. One is the recalcitrant nomadism of the people - a cultural characteristic not entirely compatible with the long term maintenance necessary to establish productive gardens. In this region all the outstations had been unoccupied for a long time and were thus showing signs 
of neglect (unwatered, overgrown with grass and prickles, vegetables destroyed by birds and rabbits). Added to this was a rather obvious lack of interest in gardening in general. The owner of Puntitjarta may be an exception to this but in general it was apparent that the people did not really care for gardening. None of the people that came with us to the oustations ever attempted to water or tend any plants in their, or anyone else's garden. Furthermore when asked the names of many of the plants the owners of camps often did not know them.

We thus need to stress a recurring point in this report. That is, unless a project is motivated and directed by Aboriginal initiatives it is unlikely to succeed, particularly if subsequently left to Aborigines to run. It seems foolish to set up European style gardens containing European vegetables that require European managment practices, technology and hardware and then expect unskilled Aboriginal people to maintain it with European type enthusiasm.

As a final point it is interesting to note that the gardens in the Docker River region are reminiscent of the earlier gardens in the Luritja Homelands in size and overall design. Given this, in addition to the points already made it seems likely that the gardens at Docker River outstations may also fold up once Europeans leave or cease to provide impetus to look after them. We made the point when discussing the gardens in the Luritja Homelands that incidental cultivation of strategically placed popular European plants in conjunction with traditional food plants may be a viable alternative to the European style horticultural developments at outstations so far discussed. We saw several developments in the region which tended to suggest that this form of incipient agriculture is a realistic option for the future. For example the most healthy and productive part of any of the outstation gardens was the large pumpkin patch at Puntitjarta. This was thriving and yet was growing virtually wild. It required no human presence - being watered by overflow and spillage from the water tank. Also the gardens at Tjuninanta and Kutjuntari were overgrown with bush tomatoes (S. centrale), the garden at Tjunti had a very large bush plum tree growing in it and at Puntitjarta an plate 6.7 and 6.8 exotic species of sweet potato had been planted thus suggesting the possibility for cultivating the native bush potato. At Docker River a local had brought seeds of a large northern bush tomato ( $S$. diversiflorum) from Papunya and had grown plants from them. Another man is also reported to have grown and processed wild tobacco ( N. excelsior) at a camp called kulka in the Pitjantjatjara region (Kalotas: 1984: 51 ).

Given these precedents it would seem there is the potential to domesticate wild food and hardy, popular European crops if the latter are placed in sensible places such as near hand pumps or under water tanks, around soaks and adjacent bores where they can grow with minimal care. It is our impression that this is a realistic alternative to the horticultural methods used so far and that it is the only realistic way of introducing the Aborigines gently to the fundamental principles of horticulture.

\section{Camp Improvements}

Some of the people had planted trees in their camps to provide shade and shelter. This was most apparent at two of the older camps, Tjunti and Tjuninanta where many trees had become established. At Tjuninanta the camp was very attractive, nestled on the banks of the Hull River, shaded by bamboo and rows of red gums, bean trees and jacaranda trees. At Tjunti the same effect had been achieved planting red gums, bean trees and white cedar 


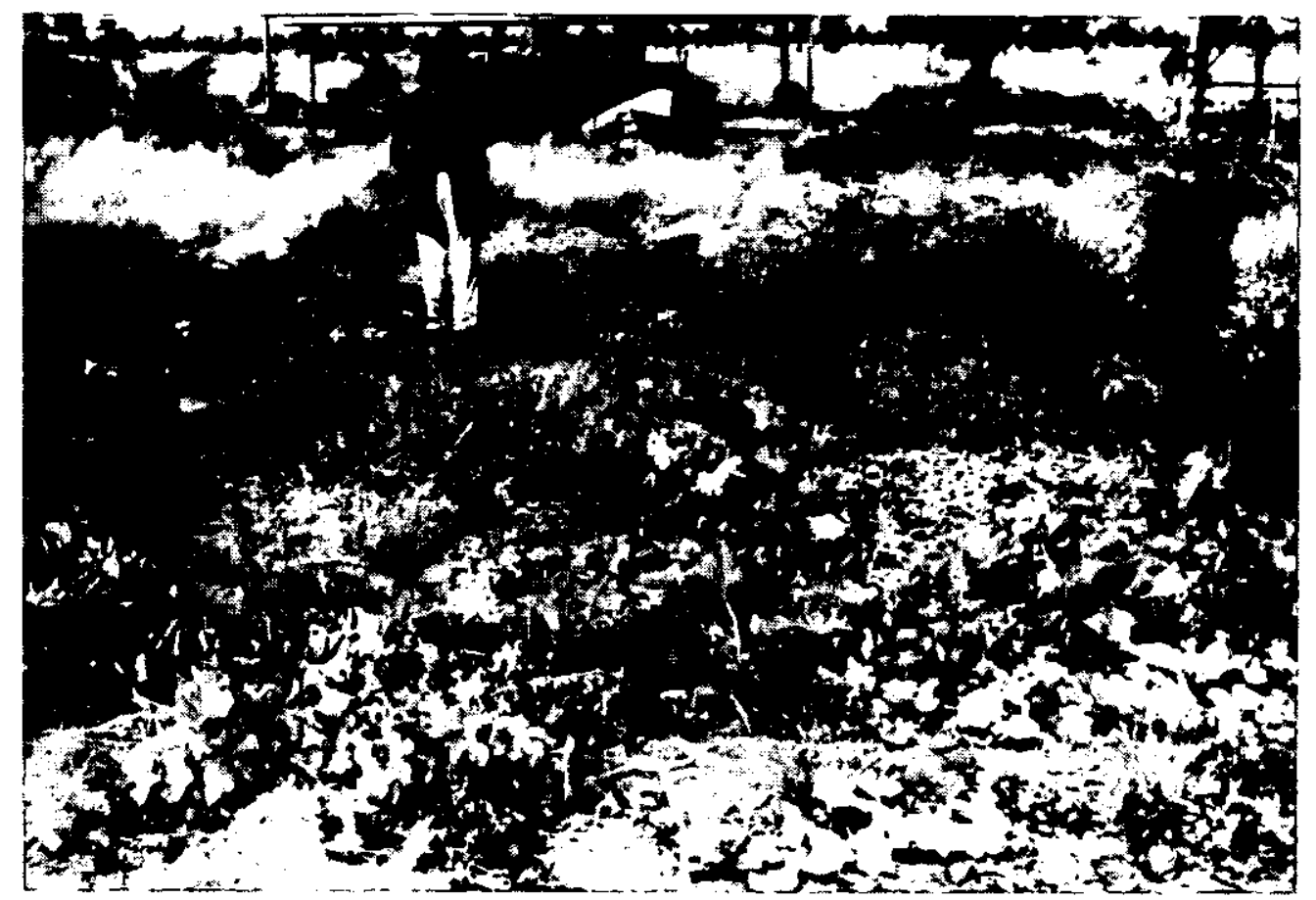

Plate 6.7 Large pumpkin patch at Puntitjarta

(note humpy underneath hexagonal shelter in background)

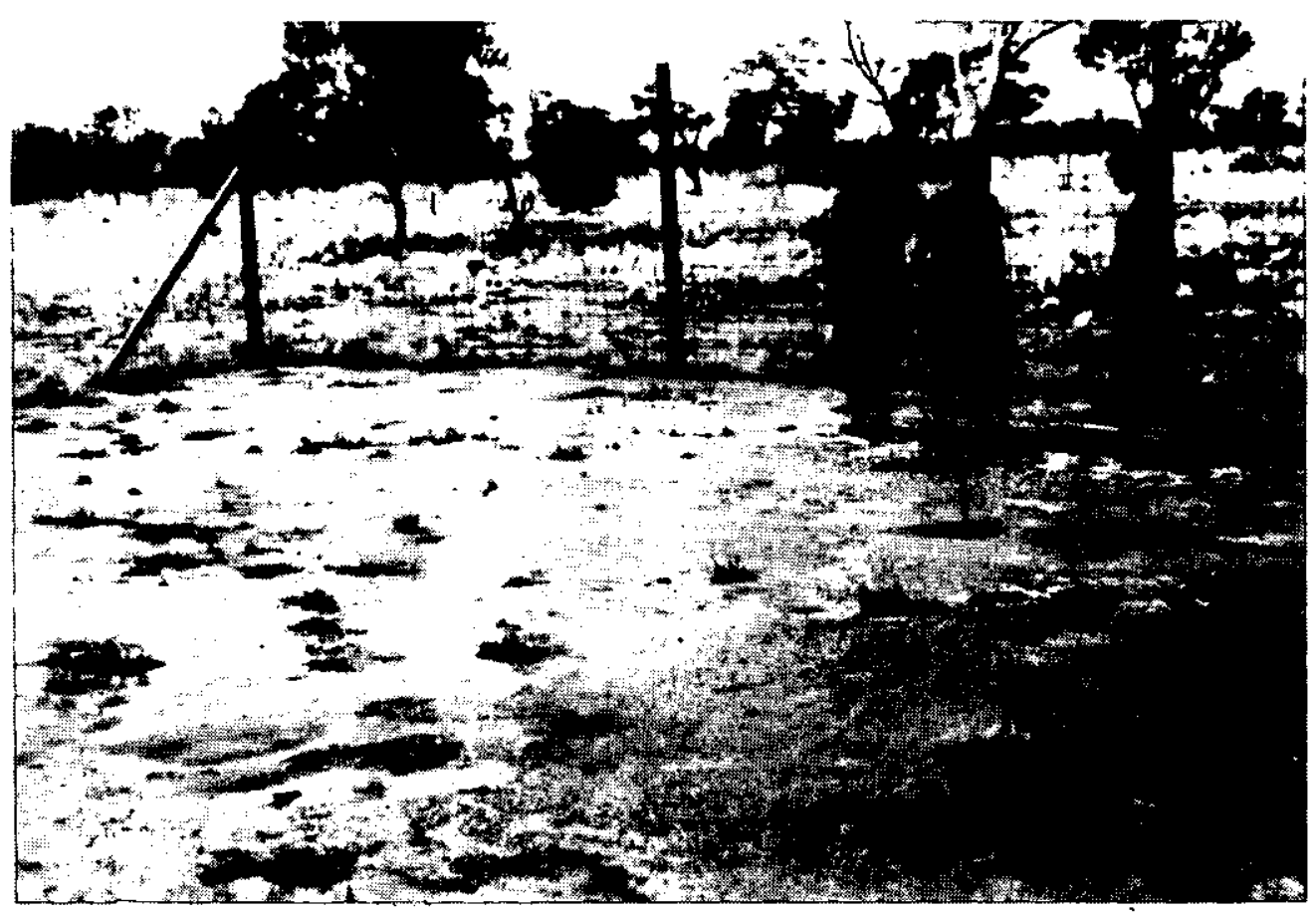

Plate 6.8 Dead garden at Warrapura 
trees. Native bean trees are quite popular in the region and had also been planted at Kunapula and Tjunti. They do not grow this far south naturally and the plants we saw had been planted by the Aborigines from seeds collected at Papunya. Most of the trees were growing well and appeared to be surviving despite occasional frosts and cold winters. Several camps had also used the creeper chinese lantern to provide shade around shacks. We were particularly interested in one shack at Kunapula. Here the creeper was falling attractively all over the verandah of the camp and we noted that the Aborigines ridiculed the owner because his shack looked 'like a whitefella' home. We were interested in this comment as it made us wonder if this apparent distaste of appearing too much like a 'white fella' was universal and if so to what extent this feeling was an inhibiting factor in the aesthetic and economic development of outstations generally.

Animal husbandry

No one we spoke to from any of the outstations expressed any interest in any form of animal domestication. Nathan and Djabanangka (1983:142) recorded that the people from Tjukula had plans to muster camels but this appears not to have eventuated yet. The people from Tjukula did have a young camel at Docker River when we were there but this escaped a few weeks after we left. The owner of Kurkatingara had some goats at Docker River which he had obtained from an outstation south of wingelina. These goats were apparently causing havoc at Docker River by eating people's food, windbreaks and shrubs which had been planted around houses. The Aborigines generally dislike the goats and had even volunteered to take them back to Wingelina for the owner if he would let them. Goats are a potential source of meat and milk for camps in the rocky country around Docker River but the Aborigines were not interested in attempting to run them; claiming it was impossible to keep a garden as well as goats because of the damage they did. Furthermore, the ecological risks of wild goat herds in conjunction with the large rabbit population could be quite substantial (Plate 6.9).

\section{Tourism}

There is potential for the people at Docker River and the local outstations to capitalize on the emerging tourist industry in central Australia. The countryside around Docker River is very beautiful and presently collects some of the tourists which spill over from Ayers Rock who simply 'want to get off the beaten track' and return to Perth via the Gun Barrell Highway. Tourists invariably stop at a cave on the road adjacent Tjunti (in which Lasseter lived just before he died) and also stop at Docker River for food and petrol. The Aborigines do little to capitalise on this - although some of the women do make a few wooden bowls, clapping sticks and model animals for sale. Currently most of these goods are sold through Ayers Rock - although most of this outlet is tied up by Amata and Ernabella. We would imagine that an outlet set up at Lasseter's Cave by the people from Tjunti or at Docker River would provide a supplementary source of income for the locals.

Currently about one vehicle a day passes through Docker River and for some good reasons the Aborigines resent this. The tourists tend to be overly curious, a little too free with their cameras while remaining remarkably tight fisted with their money. Tourists have also been known to trespass sacred sites and thus the Aborigines would rather keep tourists away altogether. Once, for example there was a plan to develop a large painted cave near Walka as a tourist attraction. A road and car park were prepared by Ayers Rock rangers but the Aborigines told them to go away. 


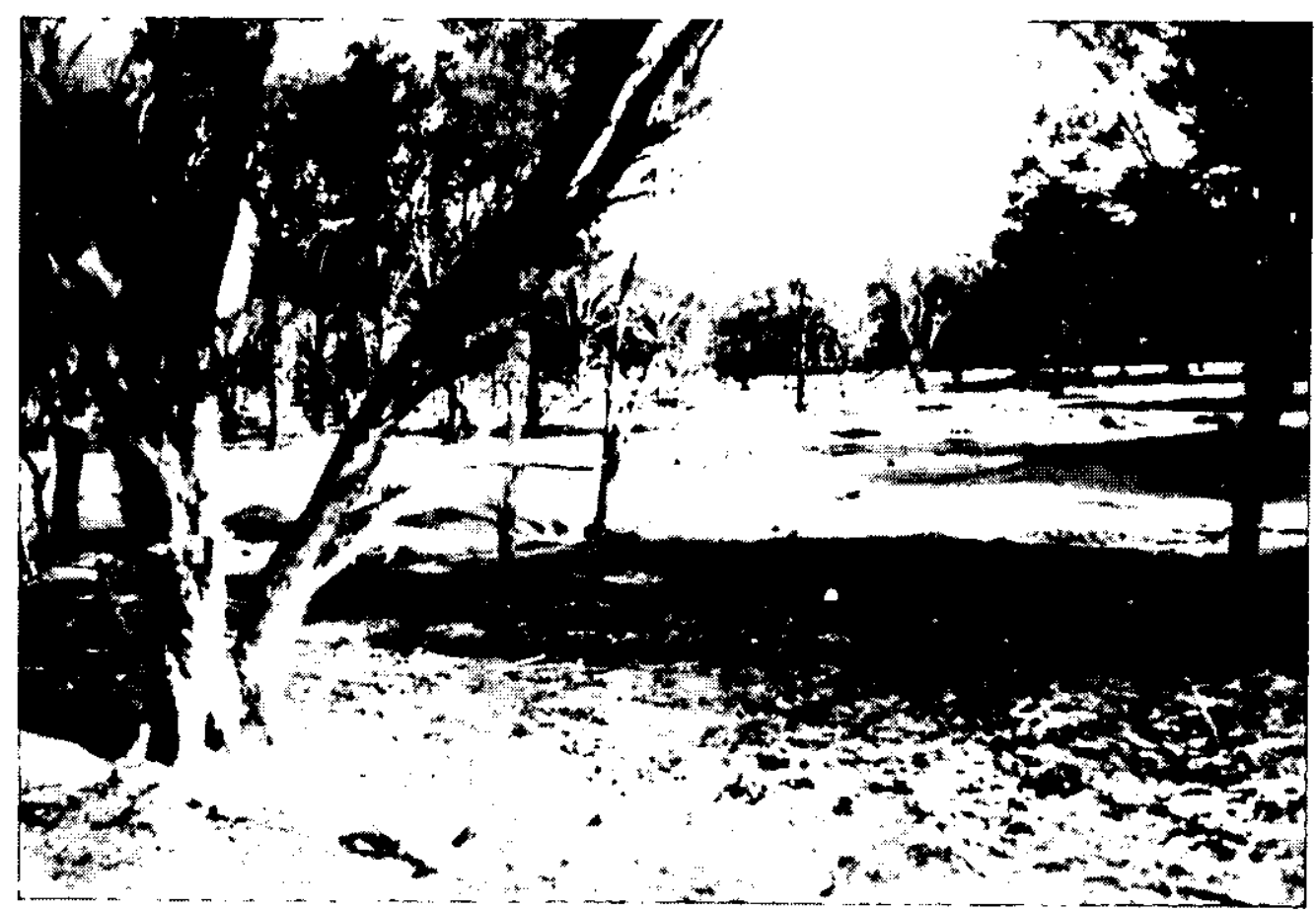

Plate 6.9 Destruction of ground cover around areas of rabbit infestation

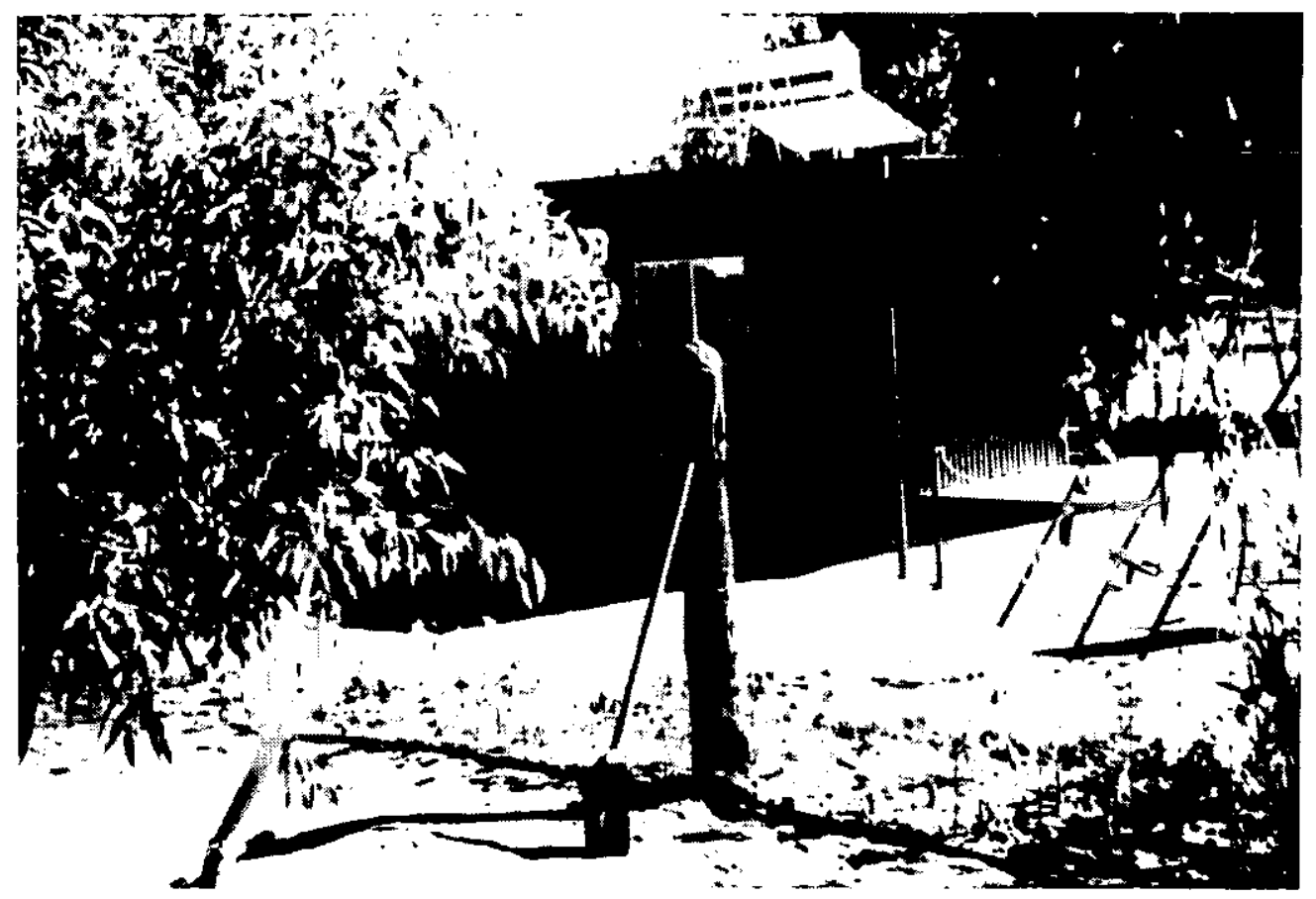

Plate 7.1 Fibro house at Katjikatjitjara - note geraniums behind fence and abundance of red gums planted near house 
Chapter 7

Pitjantjatjara/Yangkuntjatjara Homelands

Background

The history of the Pitjantjatjara/Yangkuntjatjara people in the vicinity of Ernabella is basically the same as the history of the population of Pitjantjatjara/Ngaanyatjara living near Docker River. The same explorers (Giles, Gosse, Tietkens, Carruthers) travelled through the country. The same pastoralists set up properties in the general region and the Aborigines also came into regular contact with prospectors and doggers. Two developments of critical importance in this region, however, were the construction of the Adelaide to Alice Springs telegraph in 1872 (Willis 1981) and the establishment of Ernabella Mission in 1937. The former attracted Yankuntjatjara people east, away from their traditional lands in the Musgrave Ranges and these were subsequently occupied by Pitjantjatjara people from the Mann Ranges. Ernabella Mission attracted these Pitjantjatjara and remaining Yankuntjatjara people from the bush to the European settlement (see Hilliard 1968; Layton and Rowell 1979; Last 1978; Toyne and Vachon 1984 for history of the region).

Ernabella Mission was established following suggestions and recommendations of Duguid (1972) and Love and Balfour (Hilliard 1968) in the early 1930s. Ernabella Station had already been set up in 1933 and by 1936 (the year before the establishment of the mission) contained 1,950 sheep, 16 unbroken horses, four camels, 220 goats, 20 fowls and a garden with vines and fruit trees (Hilliard 1968). The original objective of the mission was to prevent the severe culture shock which was expected if the nomadic Aboriginal population from the region came into contact with European society unprepared, rather than purely to provide the Aborigines with christian enlightenment. The concern expressed for the Aboriginal people by Europeans in those early years seems to have pervaded the subsequent history of Ernabella (see Last 1978) and it was our experience that the contemporary European staff generally had a higher level of commitment to, interest in and understanding of local Aboriginal culture than at other communities we visited. For example, the majority of Europeans who had been in the community longer than six months could speak Pitjantjatjara; a situation unparalleled in any other community visited.

The Pitjantjatjara/Yangkuntjatjara people living in the Ernabella region today have a long and varied history of contact with Europeans. They have been in contact with Europeans for over 100 years and during that time have worked and lived with rail workers, doggers, miners, explorers, pastoralists, doctors, missionaries and tourists. Even academics were visiting the region before the establishment of the Mission and since then there have been others (see Basedow 1904, 1914; Tindale and Hackett 1933, Edwards 1966; Silberbauer 1971; Yengoyan 1968). Hilliard (1968:84) correctly points out that before the establishment of the mission the Aboriginal population had 'seen white man at his best, his worst and most curious'.

This relatively long and diverse experience with white people seems to have reflected itself in the Aboriginal community living at Ernabella and the neighbouring outstations. The Aboriginal people appeared more sophisticated than other Western Desert people we worked with. This is a difficult concept to quantify and perhaps only means that the Aborigines have adopted more European ways. We visited Ernabella directly after working at Kintore and were struck by the social and behavioural differences. We noticed that, 
for example, at Ernabella the children were always dressed and were usually well dressed. Very few had runny noses or bung eyes and most had clean hair. We frequently saw women driving cars and noticed many women had modern European hair styles, were fashionably dressed and wore earrings. Everyone lived in well kept houses and people drove private vehicles which were relatively well maintained. The majority spoke English well and camp dogs were better cared for. The school was clean and the settlement less vandalised. We saw very few people walking carrying traditional implements. The Aborigines generally seemed to understand 'white fella' thinking and expectations and there seemed to be a feeling of co-operation and understanding from both sides. The Ernabella people in fact seemed to have moved closer to what we would consider an ideal juxtaposition of cultures; where the Aborigines, have retained those apsects from their culture which they consider important while adopting those from European culture which seem of value. This certainly reflected itself at the outstation movement where aspects of European and Aboriginal culture are clearly interwoven. In most outstations there was a strong sense of traditionalism; exemplified in the selection and preparation of particular bush foods, the construction of traditional implements and participation in ritual myths and songs. At the same time these traditional characteristics were continued with an acceptance of European religion, the use of relatively sophisticated European housing and facilities at camps, the adaptation of European agricultural and hunting methods and concepts of land ownership.

The motivation for outstation development also seemed to be both Aboriginal and European inspired. Some outstations such as Katjikatjitjara and Wintuwintutjara (Fig. 7.1) reflect the deliberate attempt to be close to and look after sites of religious significance. Some camps such as Ngarutjara were set up primarily to alleviate and get away from social problems of drinking and petrol sniffing at Ernabella. Others such as David Well and Eagle Bore were established as somewhere for the owners to 'get away from it all'. In these cases the camps were set up by men who were council chairmen and wanted somewhere to escape Ernabella and the frustrations of council life. Originally, for example, the owner of David Well used to visit his site on weekends. He is a Pitjantjatjara man and wished to set up an outstation on Yangkuntjatjara country. He, like the owners of Tja Tja, Itjinpiri, Eagle Bore and Araluen, had no traditional claim to the area and had to ask the community permission to set up their particular outstations. Emphasising the adoption of European concepts of land ownership we were surprised to find that land surrounding several camps is in the process of being fenced of $f$ and that the owners are very definite about who occupied the land and what formalities were required before visiting. For example we had to receive permission from individual owners and be in their presence before we could visit the camp.

Some of the outstations around Ernabella are particularly well known in relevant government and anthropological circles. They have a successful reputation and their horticultural endeavours are often quoted (Coombs 1978) and have been adopted with varying success in other regions. Ernabella itself is a centre which attracts considerable academic, political and government attention. DAA frequently uses some of the Ernabella outstations (particularly Katjikatjitjara) to impress visiting dignitaries. During our visit to the region someone was conducting PhD research into the development of arts and crafts at Ernabella and a Professor was conducting anthropological research. Two independent government task forces also visited Ernabella to investigate 'womens needs' and there was a major visit by the South Australian Minister for Housing and his entourage. Because of this kind of pressure on the community we were advised against visiting 
Figure 7.1

Location map of outstations near Ernabella

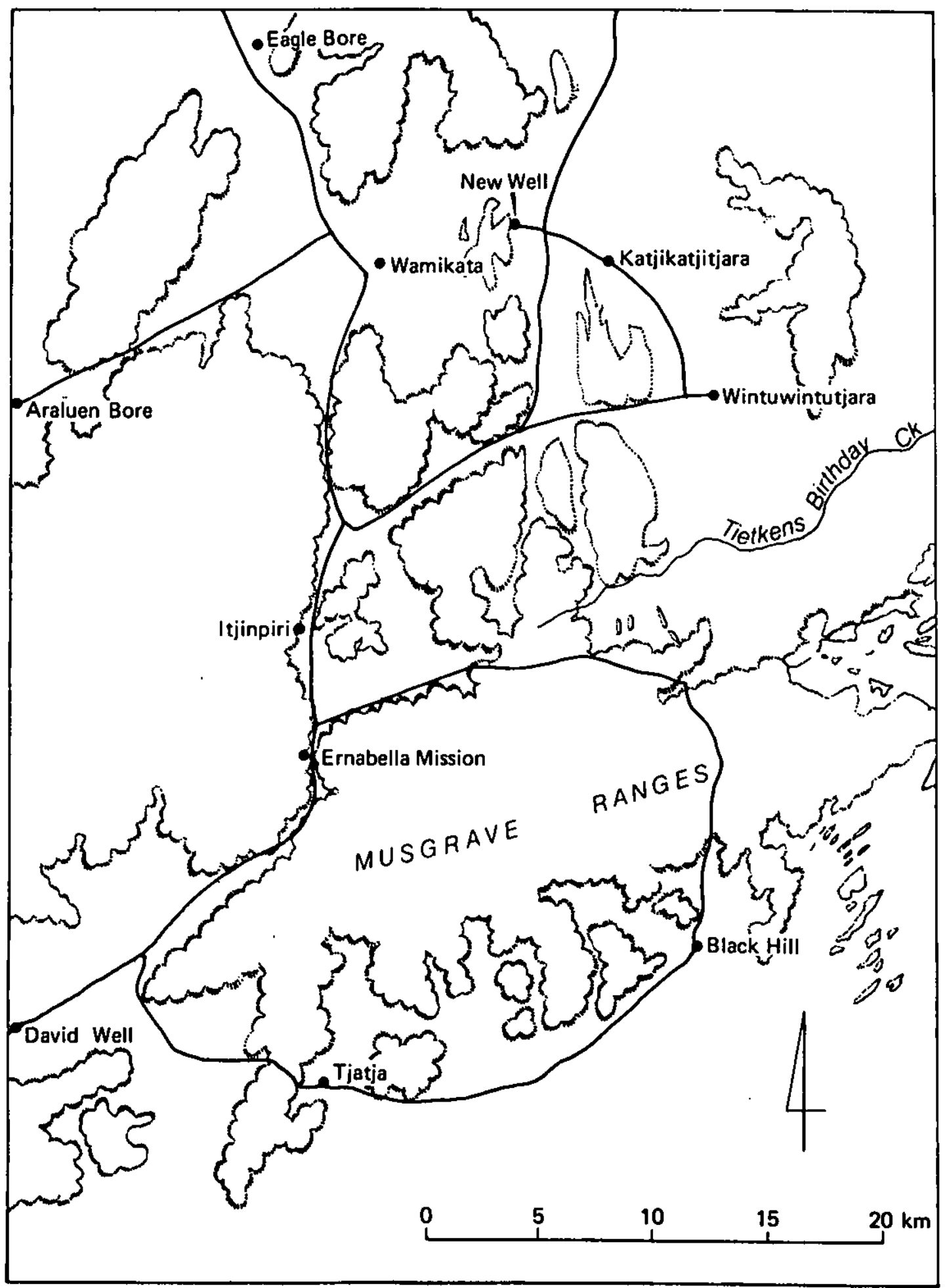


the Ernabella outstations. We were told they had been 'done to death', and although we know this to be true, there is virtually no published data on the region. In fact we were suprised to find that apart from papers dealing with outstations on a regional basis (e.g. Coombs 1978b; Wallace and Wallace 1977; Brokensha and McQuigan 1977; and Downey 1977) the only documentation of the movement consists of one skimpy report held by DAA $(1978 / 119(2): 167)$, and four community profiles (for Itjinpiri, Wamikata, Katjiktjitjara and Ngarutjara).

Thus the historical outline of outstation development from Ernabella is rather sketchy. It seems the first outstation established from Ernabella was at Fregon in 1961 (this outstation is now classed as a community and administers its own set of outstations). Further east, other outstations such as Wingelina (1966) and Puta Puta (near Pipilyatjara) were established throughout the 1960s (Wallace 1977). Itjinpiri appears to have been the first outstation established in the vicinity of Ernabella and was set up in about 1976. This was closely followed by Katjikatjitjara, Wintuwintutjara and Wamikata. The Aborigines claim that these older camps are 'done now' indicating they are more or less fully equipped and populated. Next were Black Hill, David Well, Tjatja and Ngarutjara and the most recent camps are Eagle Bore, Araluen, Umbaganda and New Well. In the course of our investigation we visited nine of these camps (David Well, Tjatja, Black Hill, Wintuwintutjara, Katjikatjitjara, New Well, Itjinpiri, Eagle Bore and Araluen (Table 7.1). The three camps not visited were Wamikata, Umbaganda and Nganutjara. This was because there had been a death at Wamikata and the remaining camps were unoccupied during our stay. We only made a fleeting visit to Black Hill as the owner was away at the time of our visit.

\section{Location and Linguistic Affiliations}

Unlike outstations in other regions the outstations in the Musgrave Ranges are all very close to Ernabella. In fact the bulk are within $30 \mathrm{~km}$ of the community (Fig 7.1) and the most distant, Ngarutjara, is barely 50 $\mathrm{km}$ away. All the outstations are located in South Australia although one, Eagle bore, is very close to the Northern Territory, border. To the south of Ernabella are David Well, Tjatja and Black Hill. To the east and north east are Umbaganda, Wintuwintutjara, Katjikatjitjara and New Well and to the north are Itjinpiri, Eagle Bore, Araluen and Ngarutjara. There are no camps in the country immediately west of Ernabella.

All these camps are situated on Yangkuntjatjara land, vacated in the early 1900s. The Yangkuntjatjara are in the process of reclaiming the land and one can sense a simmering uneasiness and some divisions between the Yangkuntjatjara and Pitjantjatjara people. This tension manifested itself prior to our visit in prolonged debate over who should become the outstation chairman. The final choice was a Yangkuntjatjara man from Katjikatjijara. Yangkuntjatjara people pointed out that Pitjantjatjara country is 'really bush country' to' the west but now Pitjantjatjara are living 'in Yangkuntjatjara place'. They say 'now we've been giving him to Pitjantjatjara people'. Pitjantjatjara people are certainly the dominant group among the outstation owners and only the owners of the eastern camps (wintuwintutjara and Katjikatjijara and possibly New Well) were Yangkuntjatjara and have traditional claims to this land. The southern and northern camps belonged to Pitjantjatjara people and in each case the owners had to gain permission from the community council before being established. We were not in the region long enough to determine if this disquiet will eventually destabilize the homeland movement as it did in the Luritja Homelands, but for reasons set out below we consider this unlikely. 


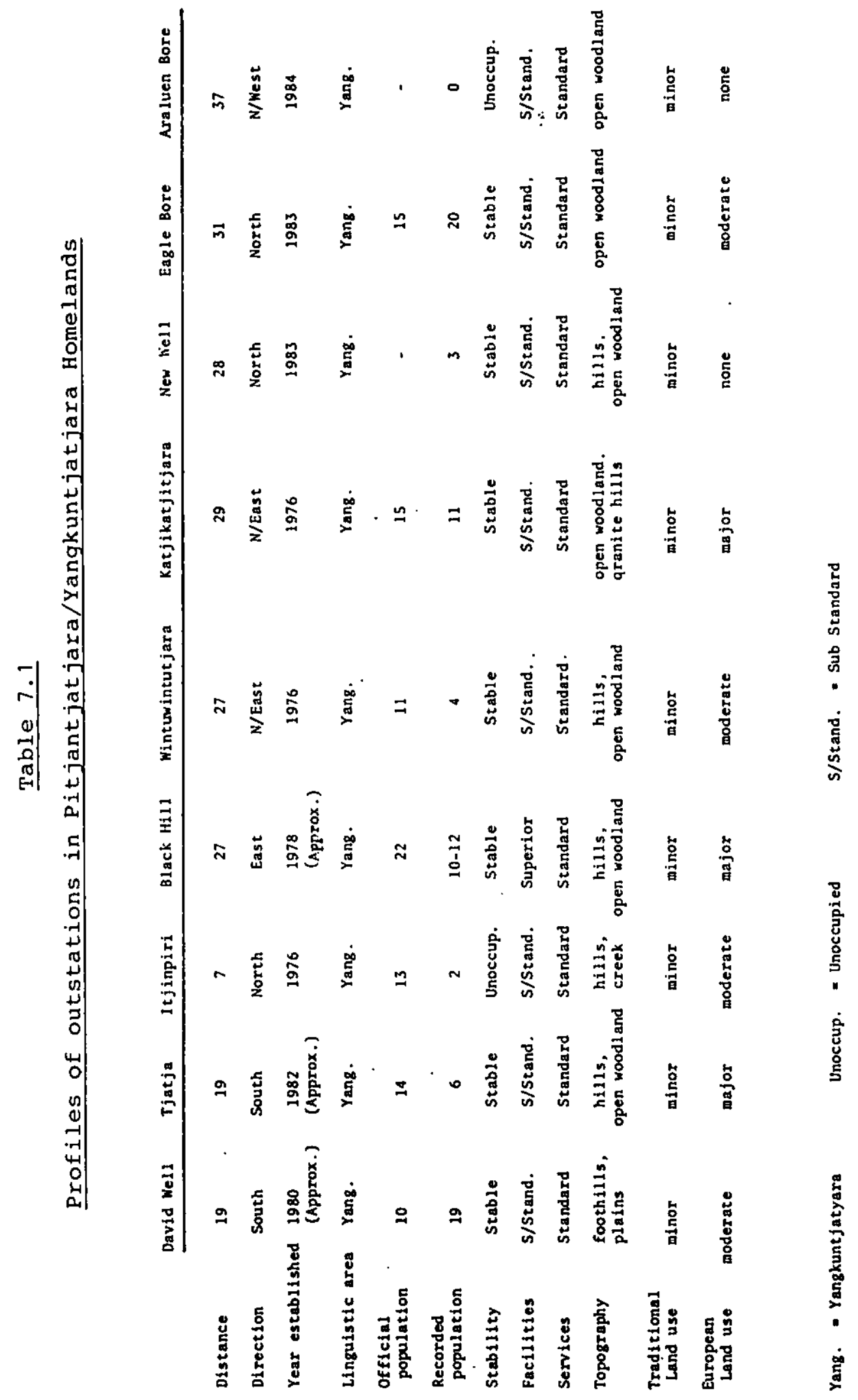




\section{Population}

\section{Number and Composition}

We were told there were approximately 130 people living on outstations in the Musgrave Ranges; about half the original population of Ernabella itself. During our visit to the region about half that number (70 people) were at camps. The largest groups of people were at David Well and Eagle Bore. Nineteen people were camped at David Well although this number fluctuated somewhat as the group included a couple from $T$ jatja and half a dozen visitors who were taking part in a period of ritual singing at the camp. The composition of the group at David Well was well balanced and contained six children under the age of 16 , seven single men, two middle aged women, one middle aged man and three male pensioners. About 20 people were camped at Eagle Bore. This group contained people from Wamikata who had moved following a recent death in the camp and some people from Itjinpiri. The sex and age composition of this group appeared quite well balanced, but we did not attempt to obtain accurate figures because of the 'sorry business' in the camp.

Smaller groups of people were living at Katjikatjitjara and Black Hill. There were 11 people at the former and the group was made up entirely of pensioners with the exception of one little boy who was visiting from Papunya. There were about nine people at Black Hill but again we do not have accurate figures as the owner was away and we could not obtain permission to make a detailed investigation.

Smaller groups of people were camped at Tjatja, Itjinpiri, Wintuwintutjara and New Well. One middle aged man and two middle aged women were camped at New Well. There were four people at Wintuwintutjara; a young boy, his parents and the owner of the camp. Prior to our visit a car load of about five people from wintuwintutjara had driven to Ernabella for supplies. There were only an old man and woman at Ijinpiri. This couple owned the camp and but were only staying for a short time to tend the garden and check on the camp. They, and the rest of their family were presently living at Eagle Bore where they said there was more wood. The couple told us that supplies of wood were poor near Intjinpiri and the winter was cold. These people were apparently intending to return to Intjinpiri in the summer. It seems likely that the seasonal occupation of Intjinpiri will continue.

Six people were living at Tjatja - two middle aged adults and four young children. An elderly couple owned Tjatja but were living at David Well during most of our visit. The old man had an arthritic leg resulting from an old spear wound and was camping at David Well because a vehicle was available there if he needed to go to Ernabella for treatment.

\section{Stability}

As mentioned in the introduction all the outstations in the Musgrave Ranges are very close to Ernabella. As a result they are as much like outer suburbs of Ernabella as typical outstation camps. Because of their proximity to Ernabella (and other communities such as Kenmore Park, Fregon and Mimili) there is considerable daily movement between the camps and the communities. It is not unusual for example, to see people from outstations in town every day and returning to their camps at night. People come into 
town frequently to work, get pay cheques, buy food, see the doctor, sell crafts, go to church and take children to and from school. The people from David Well for example, travelled to Ernabella and back daily to deliver and pick up children. The children from Tjatja go to school in Fregon and the wife of the owner at Black Hill is a teacher at Kenmore Park and travels with her children each day. Her husband is currently working on a fencing project near Fregon. At Ngarutjara the owner was a pastor at Ernabelia and thus spends most of his time in town.

There is also a strong tendency for people at Ernabella to visit and use the outstations as weekenders. To highlight this point we noted that the people at New well only used the camp in weekends and were travelling regularly from Alice Springs while it was under construction. We were also suprised to note that people travel great distances to play football and during the first weekend we were at Ernabella most of the outstations were vacant as people had gone to the football at Pipalyatjara. This is a distance of $750 \mathrm{~km}$ return. The weekend before they had apparently driven all the way to Jamieson - another $180 \mathrm{~km}$ to the west. (This is comparable to people from Canberra driving to Melbourne over corrugated dirt roads each weekend to watch a football match!). We were told by several people that there is a constant movement of Aboriginal people between Oodnadatta and Warburton through the Pitjantjatjara Homelands. Outstations are dotted all along the main road and thus provide an additional function of food and water stops as well as family outstations. Apart from the very obvious mobility of Aboriginal people in this region there was very little evidence of instability in the homelands movement around Ernabella. The only camps which were not occupied during our visit were Ngarutjara, Intjinpiri, Umbaganda, Araluen and Wamikata. In each case there was a good reason for this. For example, the owner of the Ngarutjara camp spends much of his time at Ernabella as the local pastor. The people from intjinpiri were camped at Eagle Bore because of the cold but were regularly checking the camp and maintaining their gardens. The people from Umbaganda were in the process of setting up their camp and were living at Ernabella while waiting for their bore to be equipped. The people from Araluen were in the unfortunate and frustrating position of having to move their camp. They had originally cleared, fenced and set up a camp at an old sheep bore but then discovered the water was poor and had to dismantle and move the whole camp to a new site.

Our overall impression of the outstation movement was one of stability and conviction. We detected a decidedly healthy and purposeful atmosphere amongst outstation dwellers. The only elements of instability we observed were minor and appeared to be a short term in nature. Thus it appeared that the only likely cause for any regional instability was the tension over traditional rights and ownership to land between the Yangkuntjatjara and Pitjantjatjara people. We are not in a position to forsee the long term consequence of this tension but in the light of the pintupi experience in the Luritja Homelands, consider it a problem worthy of attention. We would be surprised however if the situation in the Musgrave Ranges ever developed to a situation where the Yangkuntjatjara forced the settled Pitjantjatjara people off their outstations and back to their own country. It was our impression that the present outstation sites had been selected with care and that approval for the location of camps had been given with due consideration. Also many of the Pitjantjatjara people owning outstations today, were born and/or reared at Ernabella and thus have an affinity with the local landscape rather than with their more distant country which originally occupied by their parents. 


\section{Facilities}

$\underline{\text { Houses }}$

Unlike camps in other homeland areas discussed in this report, the Pitjantjatjara/Yangkuntjatjara outstations have obtained, or are in the process of obtaining, small conventional houses. Six camps already have such houses (Itjinpiri, Black Water, David Well, Wintuwintutjara, Katjikatjijara, Wamikata). These consist of a small floor plan, verandah, glass windows, kitchen dining area, separate bedrooms and toilet with septic tanks. Some of the earlier houses (at Katjikatjitjara, and Itjinpiri) were made from galvanized iron or fibro (Plate 7.1), whereas the latter are made of Besser Brick. These houses cost between $\$ 25,000-\$ 30,000$ to construct.

Recently the Aborigines in this area were asked if they would prefer first stage houses $(\$ 4,000)$ like those in other homeland areas instead of these houses. The Aborigines declined the offer, pointing out that the alternatives were not houses. but tin sheds! The Pitjantjatjara/Yangkuntjatjara people treated their houses more like Europeans and told us that the houses were only for use by the owner of each camp. other occupants and visitors were expected to live in humpies and/or galvanized iron sheds provided by the owner of the camp. This contrasts the situation in other Western Desert areas where several families generally use the same house. Because of this difference the outstation houses around Ernabella were better cared for. For example it was not uncommon to see bottles of washing detergent and antiseptic in kitchen and laundry windows. Accommodation for friends and relatives was provided in various ways. At David Well the owner and several friends had constructed three large tin sheds for visitors from corrugated iron and treated pine logs (Plate 7.2). There were also three sheds at Black Hill, three sheds at Ratjikatjijara and one shed and several humpies at Wintuwintutjara for visitors and family.

At the camps not yet provided with houses the people were living in various shelters, wind breaks and humpies. At New Well the people had constructed a large brush shelter from branches and pine logs (Plate 7.3). At Eagle Bore the people were living in humpies and windbreaks made from sheets of iron, bushes and tarpaulins. At Tjatja the people were camped in several humpies and makeshift tin sheds.

Apparently $\$ 150,000$ has been allocated to the community for outstation houses and this seems sufficient to provide houses at the remaining camps. During our stay at Ernabella a meeting was organized with the Minister for Housing in the South Australian Government. At the time we were working with men from Wintuwintutjara and David Well and were interested to note that these men (as well as men fom Intjinpiri, Black Hill and Katjikatjitjara) had no interest in attending the meeting. We suggested that the meeting was important, and that the Minister was talking about money for houses. The Aborigines still showed no interest replying 'no, we're done now, other mob got to get house now'. Thus stating that their camps had houses and that it was somebody else's turn to set up their camp. This was an enlightening comment given the often repeated assumption that Aborigines want outstations only for the material possessions they can get out of them.

Water

Only two of the camps we visited had not been provided with windmills, tanks and reticulation. These camps were New Well and Araluen and both were 


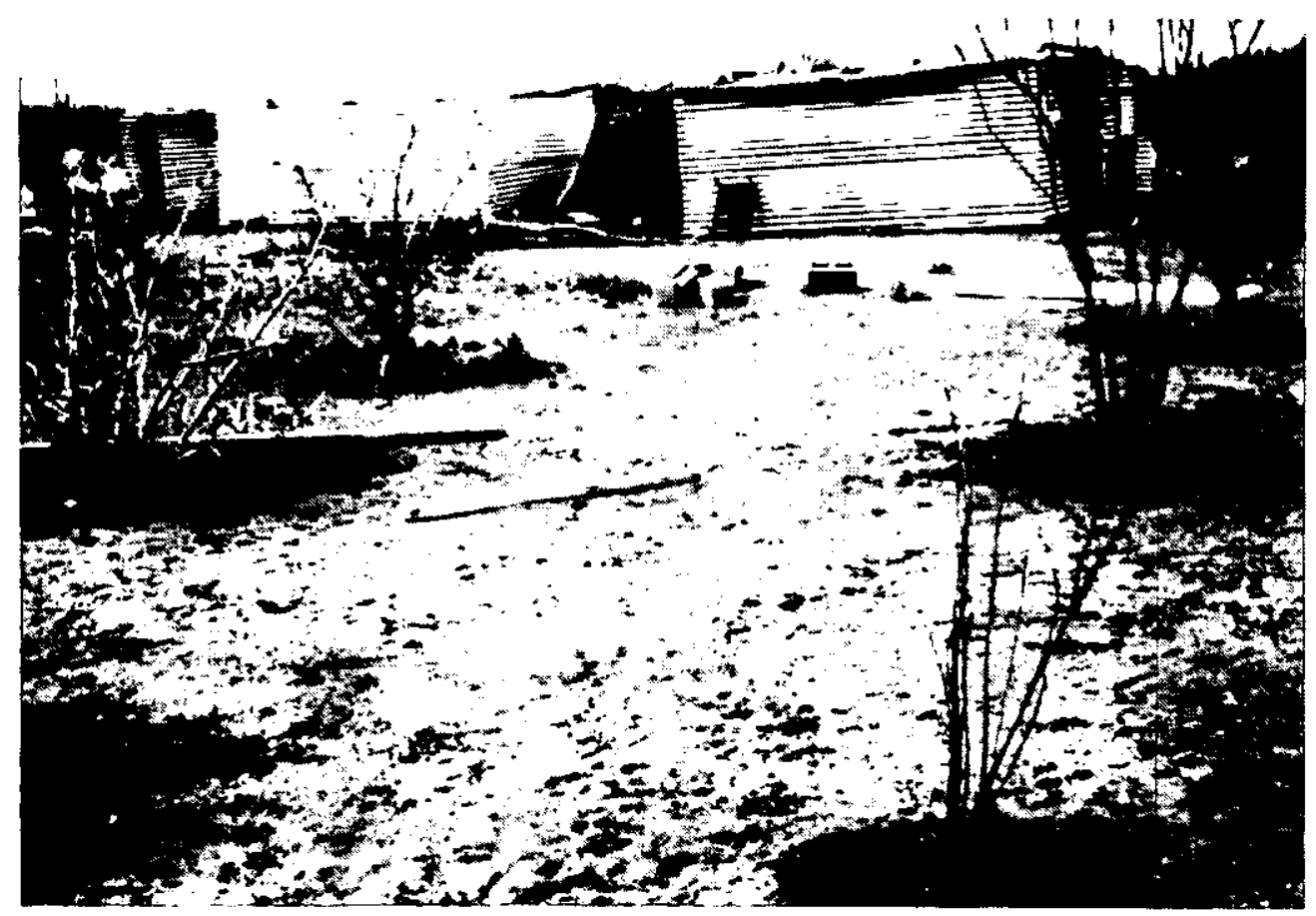

Plate 7.2 Visitor accommodation built at David Well. (Note fruit trees planted in foreground)

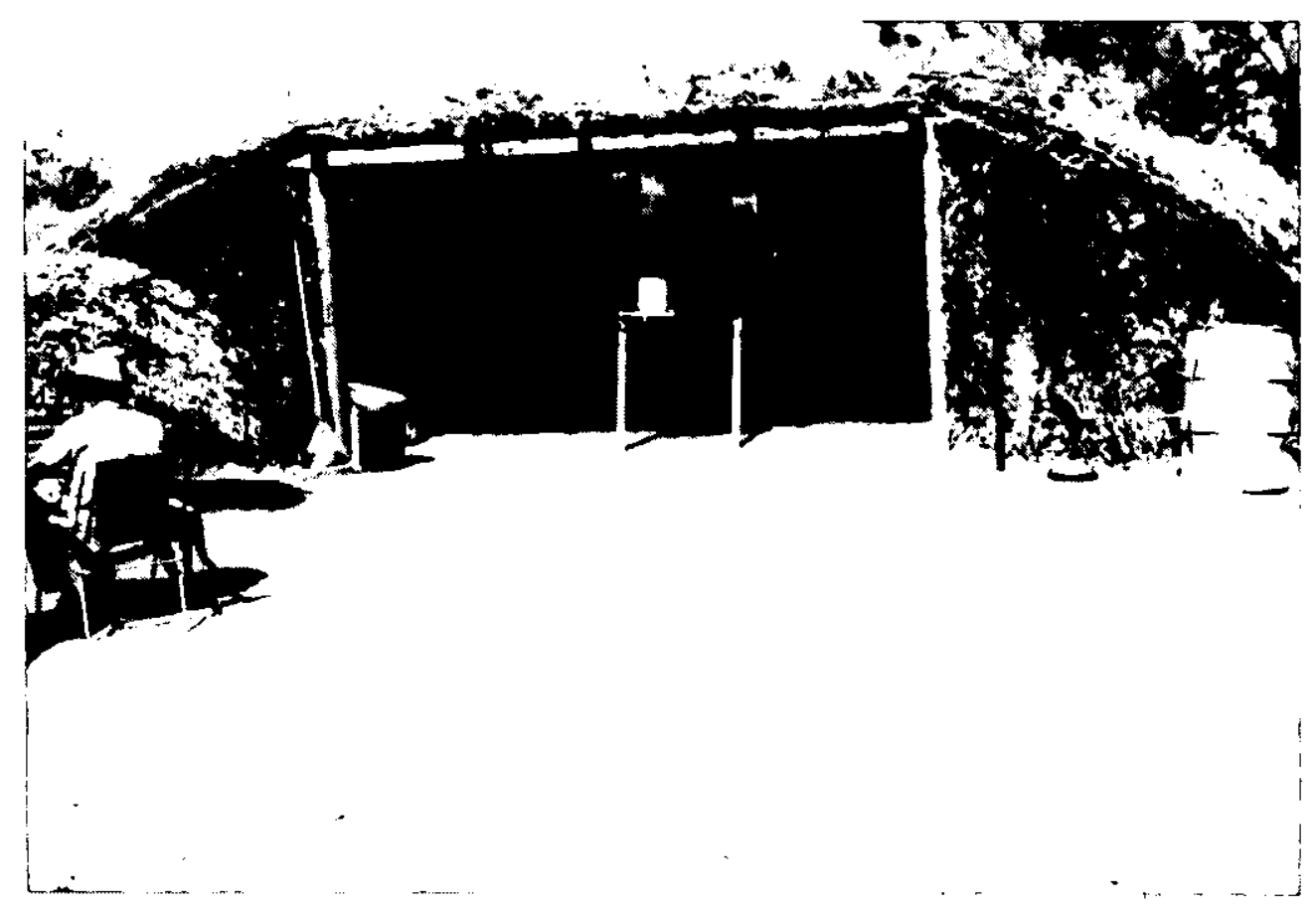

Plate 7.3 Temporary shed constructed at New Well 
located on old sheep bores which were in the process of being repaired. The remaining camps had been supplied with underground water reticulated from tanks to gardens and houses. At some camps the reticulation was quite extensive (at Eagle Bore for instance we counted 11 taps in the camp) and in each case the piping had been laid by the Aborigines. The more sophisticated plumbing, such as attaching taps, and joining pipes, had been done by Europeans. At Black Hill and Wintuwintutjara there were two bores. One of the bores at Wintuwintutjara had been equipped with a diesel pump and this was useful during the summer when the wind did not blow for long periods. Several people expressed a desire for diesel pumps so as to get water during wind droughts during summer months. This, or water tanks large enough to supply water for extended windless periods, would seem a necessity in this region. Some camps (David Well and Katjikatjijara) had rain water tanks but these were small and in any case were not much use when it did not rain.

At Intjinpiri the original windmill was washed away in a flood and the old bore is now located in the middle of the creek adjacent the camp. The creek is continually cutting towards the camp and is now getting close to the second windmill. This raises the very obvious need to plan the development of outstations with care, before they are equipped with expensive facilities.

A recurring theme in our investigation of water resources at outstations in this project has been the general poor quality of water supplies at outstations. For the Ernabella region we obtained data for five camps (Wamikata, Wintuwintutjara, Umbaganda, David Well, Katjikatjitjara) and found that all of them were supplied with water which is technically unfit for human consumption. The water at Wamikata and Umbaganda was over the acceptable levels of nitrate and fluoride respectively. The levels of fluoride were high at David Well $(2.6 \mathrm{mg} / \mathrm{l})$ and because of this the people were spending most of their time next to a soak in a nearby creek. At Katjikatjitjara the water was high in nitrate $(65 \mathrm{mg} / 1)$ and fluoride $(2.6 \mathrm{mg} / 1)$ and at Wintuwintutjara the water contained excessive amounts of nitrate $(111 \mathrm{mg} / 1)$, iron $(2.3 \mathrm{mg} / 1)$ and fluoride $(2.5 \mathrm{mg} / 1)$ (Fig 7.2).

Radio Phones ('radios') and Toyotas

In comparison with other homelands the camps around Ernabella were very badly of $f$ when it came to the acquisition and ownership of toyotas and radios. No camp, for example, had a community toyota. This was a result of the geographic location of the Pitjantjatjara/Yangkuntjatjara outstations in South Australia, beyond the reach of ABTA funds. In fact the people we worked with had never heard of ABTA funds and were puzzled as to why some people living at camps around Docker River, Pipilyatjara and Amata had new toyotas when they did not. The reason was of course that some of these camps were located in the Northern Territory. Instead of community vehicles therefore the people at outstations near Ernabella rely on private vehicles belonging to members of the camps or related family. With regard to radios only one camp (Katjikatjitjara) owned a radio. Fortunately all the camps are quite close to Ernabella, but at camps such as Tjatja where people are old and sick and there is no immediate access to a vehicle there is a definite need for some ready communication with the main community.

\section{other Equipment}

Camps in the region contained the usual array of shovels, axes, crowbars, rakes and fencing materials. The region was also supplied with 
Figure 7.2

Water quality of camps near Ernabella

Nitrate

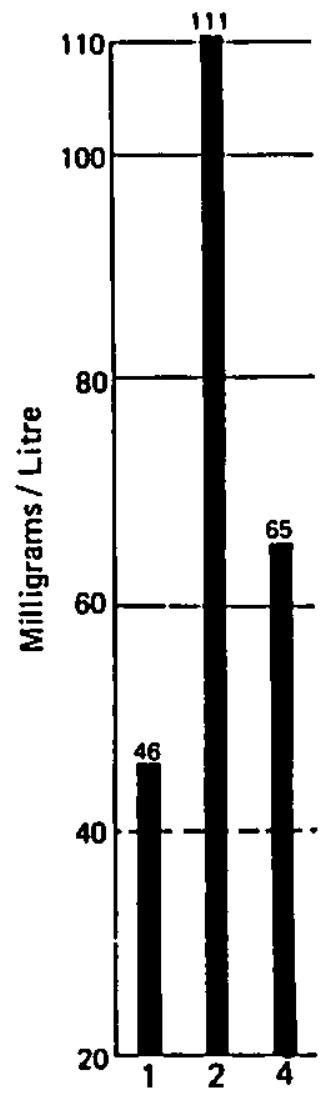

Fluoride

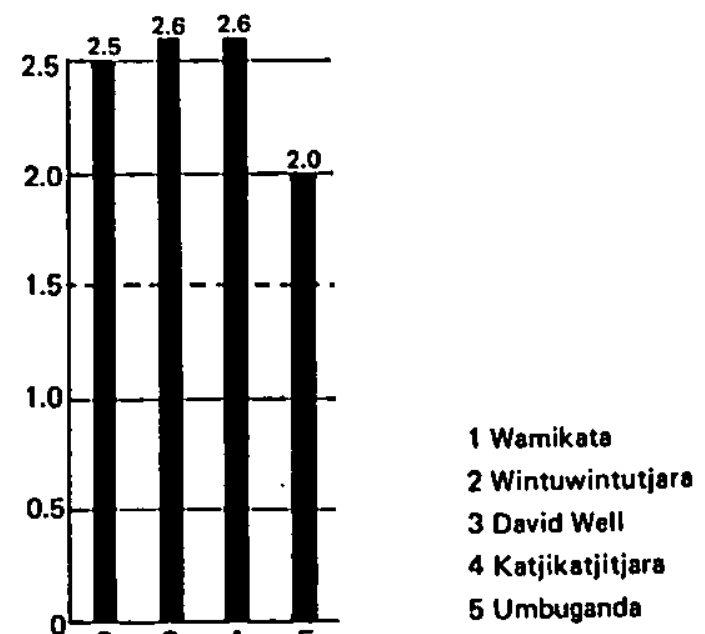

Location

- - - - Recummended Maximm Level 
several wheel barrows and two tractors which were shared between all camps in the region. Houses at most of the camps (David Well, Intjinpiri, Black Hill, Wintuwintutjara and Katjikatjitjara) were equipped with neon lights powered by 12 volt batteries and solar panels. Katjikatjitjara was also equipped with bottled gas for cooking and heating and gas bottles were being installed at Wintuwintutjara. Black Hill had the widest range of equipment. This gear included material necessary for a cattle station branding gear, water troughs, stock yards and so on, although we could not make a detailed inventory because the owner was away at the time of our visit. Large steel framed tin sheds had been built at Black Hill, Intjinpiri and David Well but at the last two camps these were empty and did not appear to be in regular use.

\section{Services}

The health clinic at Ernabella contains one resident doctor and several sisters. They provide an energetic service to the outstations and visit each camp regularly once a week. In addition each camp, with the exception of David Well, has been supplied with a medical chest.

People from outstations commute regularly to buy food and for schooling. This is considerably easier here than at outstations in other areas as the majority of camps are not far from Ernabella. Nevertheless parents still leave children at Ernabella to ensure their schooling. Others transport their children although it was apparent that some of the children living at outations do not attend school. This was a source of some concern to the local headmaster. He stressed that 'you can take food and health care to outstations but you can't take education'. This point of view may have some validity but while there have been very few attempts to take education to outstations here or anywhere else in Central Australia the assumption is difficult to prove. We also were under the impression that the School of the Air program for remote white children was quite successful and see no reason why the same or similar system could not be developed for Aboriginal children.

The school facilities at Ernabella however are very good, All the staff speak Pitjantjatjara and take an active and genuine interest in the welfare and education of the children. The school is well maintained and there is a good canteen and good sport and recreational facilities compared to other community schools we visited. We also noted that rock and roll music was played at the school during recess and lunch breaks and felt this was rather symbolic of the wholesome attitude the teachers had for their pupils.

\section{Topography}

Landscape and Land Use

The dominant topographic feature in the Pitjantjatjara/Yangkuntjatjara Homelands is the Musgrave Ranges. These mountains are made of schist and granite and rise over $1,000 \mathrm{~m}$ above sea level. The largest mountain in South Australia, Mt. Woodruff is located in these mountains. The rugged country is very beautiful and reminiscent of the Petermann Ranges although the hills are more rounded, and the escarpments and valleys less dramatic. In the eastern region around Katjikatjitjara and west near Ngarutjara large rounded granite inselbergs are common, rising from the plain like many small. 'Ayers Rocks'. Some large creeks such as Tietkins Birthday Creek dissect the plains and run out vanishing into the sandplains (Table 7.2). 


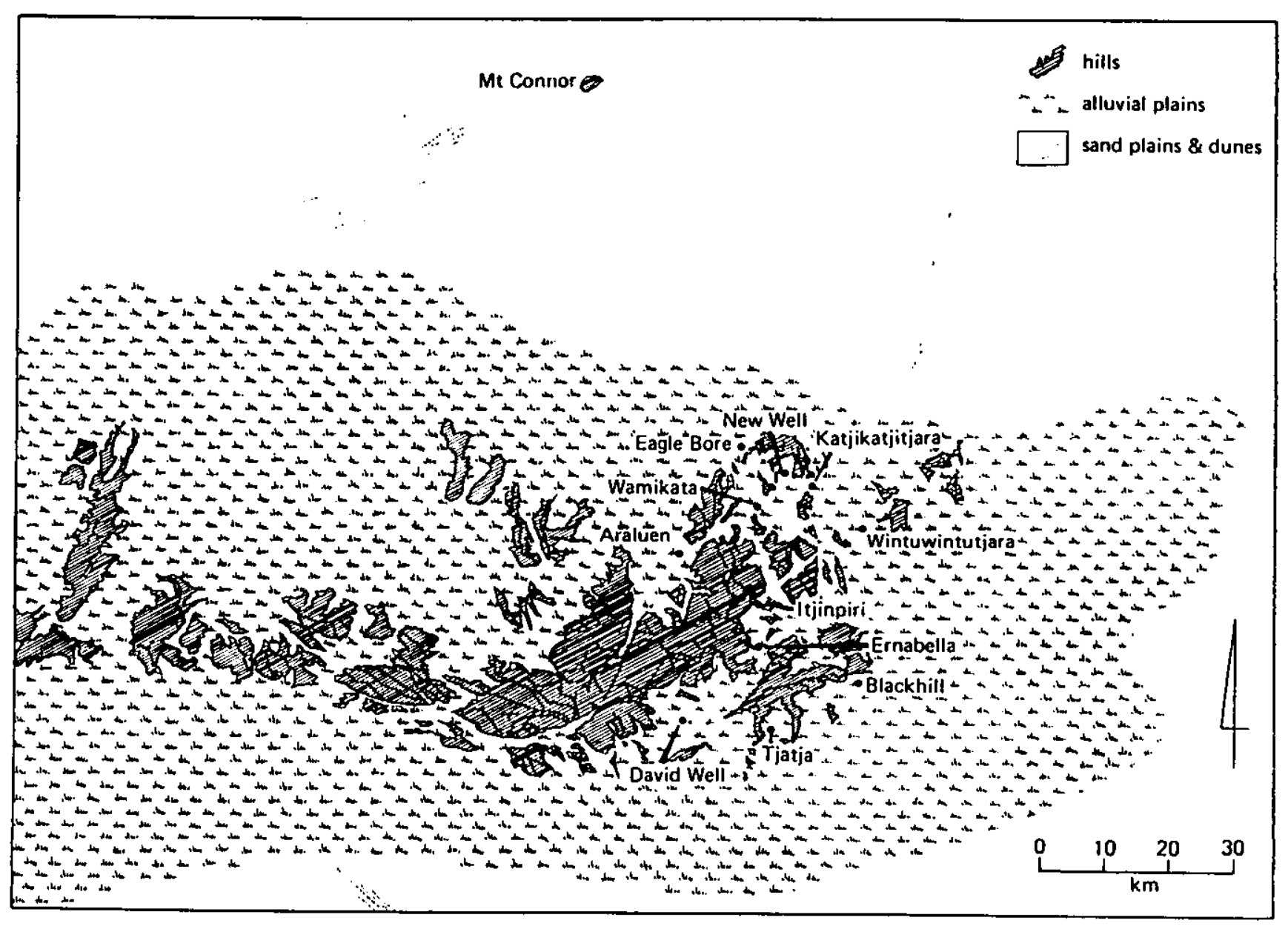

\begin{tabular}{|c|c|c|c|c|c|c|}
\hline UNIT & AREA & LANDFORM & SOIL. & VEGETATION & TRAOITIONAL & EUROPEAN \\
\hline & medium & $\begin{array}{l}\text { Mountains made of granite and } \\
\text { schist. Steep rocky talus slopes } \\
\text { fringe ranges and extend into } \\
\text { surrounding alluvial plains. }\end{array}$ & $\begin{array}{l}\text { Shallow gravelly } \\
\text { soil. }\end{array}$ & $\begin{array}{l}\text { Often bare with spinifex (T. } \\
\text { irritans and } T \text {. clelandii). } \\
\text { native pine (Callitris colume/. } \\
\text { faris) and Acacia spp. }\end{array}$ & $\begin{array}{l}\text { Source of water. } \\
\text { Euros, tobacco } \\
\text { and wild figs. }\end{array}$ & None. \\
\hline & medium & $\begin{array}{l}\text { Extensive alluvial plains inter. } \\
\text { spersed with rocky outcrops and } \\
\text { rounded granite hills. Flood } \\
\text { plains channelled with inter. } \\
\text { mittent streams. Some small } \\
\text { sand dunes. }\end{array}$ & $\begin{array}{l}\text { Course textured } \\
\text { soils and clayey } \\
\text { sands. }\end{array}$ & $\begin{array}{l}\text { Open woodland mulga (A. } \\
\text { anuera), witchetty bush (A. } \\
\text { kempeana), Hakea spp. and } \\
\text { Eucalyptus intertexta over } \\
\text { grasses and forbs. }\end{array}$ & $\begin{array}{l}\text { Hunting, collection } \\
\text { of honey ants and } \\
\text { witchetty grubs. } \\
\text { Solanum fruits and } \\
\text { firewood. }\end{array}$ & $\begin{array}{l}\text { Some cattle, and } \\
\text { sheep pastures. } \\
\text { small gardens. }\end{array}$ \\
\hline & large & $\begin{array}{l}\text { Sandplains and dunes, occasiona! } \\
\text { low limestone rises and mobile } \\
\text { sand. }\end{array}$ & Red sands. & $\begin{array}{l}\text { Shrub and tree steppe, spinitex } \\
\text { with sparsely scattered shrubs } \\
\text { (Hakes, Grevillea, Acacia) and } \\
\text { trees (Casuarina decaiseana). }\end{array}$ & $\begin{array}{l}\text { Rabbits, and } \\
\text { wild fruits. }\end{array}$ & None. \\
\hline
\end{tabular}

Table 7.2 Land Summary of Ernabella Region 
$\underline{\text { Climate }}$

The climate of Ernabella has broad similarities with Docker River, although the former is generally slightly colder and slightly wetter. For example winter temperatures are consistently a few degrees below those of Docker River, with a daily range average between 19 and 27 degrees Celsius during the day and between 4 and 11 degrees Celsius during the night. The region gets about 20 days of frost each year (Hall et al. 1981). In addition to summer rain, winter rain comes from southern low pressure systems. Rainfall decreases in late winter and spring and september is the driest month. Temperatures increase during sumer to mean daily maximum of between 30 and 35 degrees Celsius and mean minimums of between 18 and 26 degrees Celsius. The countryside receives most of its rain in summer from thunderstorms extending south from tropical low pressure systems. Annual rainfall is variable with an average of $240 \mathrm{~mm} /$ year. Here, as in other homeland regions the evaporation rate is very high (Silberbauer 1971; Bureau of Meteorology 1975) (Figure 7.3).

\section{Vegetation}

The vegetation cover on the mountain is rather scarce. Native Callitris pines and wild figs (Ficus platypoda) grow in sheltered sandy pockets but most of the vegetation is either grasses or spinifex (Triodia irritans, T. clelandii). The plains are largely covered by low open woodland and as in other areas mulga and witchetty bush dominate the vegetation. Other common species include Cassia nemophila, Eremophila longifolia, Acacia brachystachya, A. victoriae, A. pruinocarpa, Hakea eyreana and Eucalyptus intertexta above grasses (Aristida contorta, Enneapogon spp.) and forbs. The sandplain and dunes are largely covered with spinifex with scattered Hakea, Grevillea and Acacia shrubs. Desert oaks are common on sand dunes.

\section{Plants of Economic Importance}

The range of plants frequently collected by people living on outstations around Ernabella is relatively small. It was our impression that these people are sufficiently removed from the traditional pattern of subsistence not to be interested in going to great lengths to obtain bush food and, like the people living near Docker River get most of their carbohydrate from the community store. Thus one finds that only the fastest and easiest plants to collect are still gathered with any vigour by people living on outstations.

The most frequently collected plants include wild figs and native tobacco from the hills; bush tomatoes (particularly s. centrale), from the plains; bush plum and bush onion from creeks. Witchetty grubs are also collected enthusiastically from abundant witchetty bushes in the area.

Local hard and softwoods are still used for making artefacts both for sale and ceremonial use. Mulga is the most popular wood and men also make spear shafts from Pandorea doratoxylon. The women make wooden dishes from Eucalyptus hardwoods and various model emus, snakes and lizards from the roots of red gums. 
Figure 7.3

Mean temperature and rainfall for Ernabella

\section{Temperature}

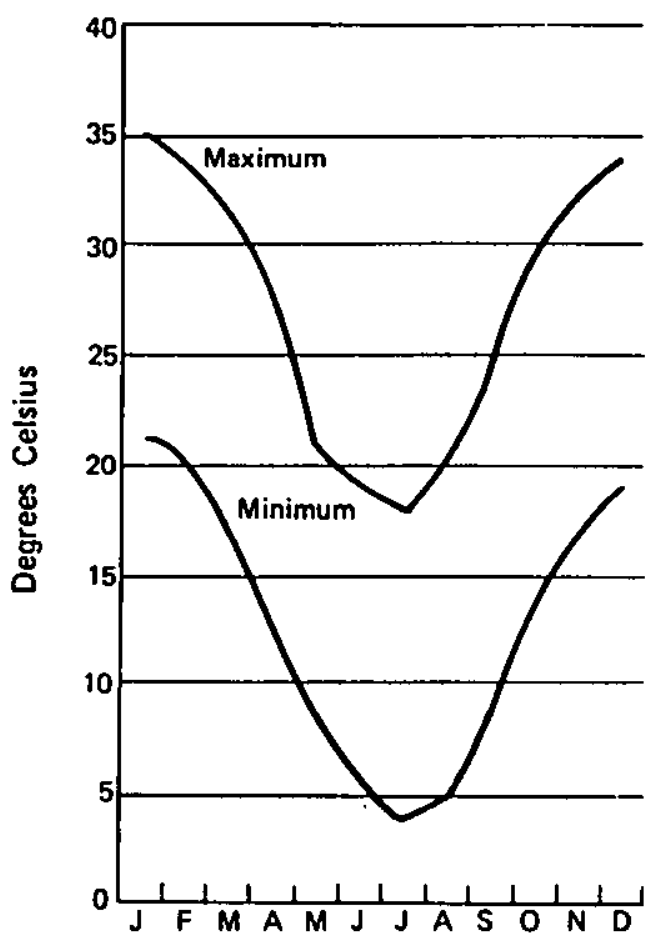

Rainfall

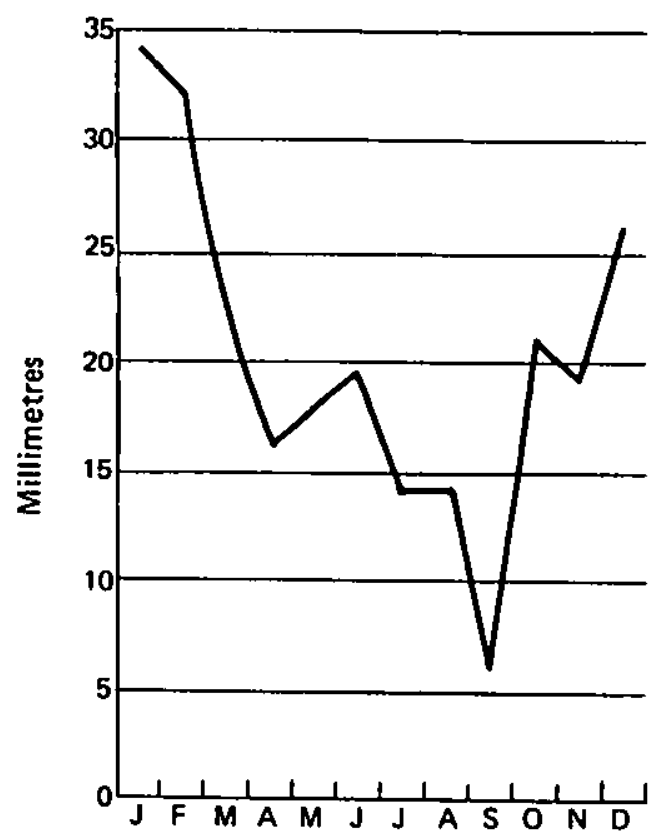


Animals

Animals still play a substantial part in the diet of people on outstations. The Musgrave Ranges, like the Petermann Ranges, provide excellent hunting grounds and it is not uncommon to see herds of 20 to 30 kangaroo hopping through the scrub. Euros are also very common in the hills and rabbits are abundant on the alluvial plains. Kangaroos are the main focus of the hunter's attention although rabbits and euros are often taken if seen when travelling.

Unlike the men we worked with in the Luritja, Pintupi and Walpiri Homelands the men in this region had good, well maintained guns. Consequently they were much more effective hunters and, for example, on the occasions we went hunting the men always returned with at least one kangaroo. The accuracy with which these men hunt was highlighted on two trips. On one of these the hunter shot two kangaroos from the vehicle while travelling at $45 \mathrm{~km} / \mathrm{hr}$ through the bush. On the other a hunter shot three kangaroos in a row as a herd attempted to flee across the plains. He had already bagged four rabbits (Plate 7.4). Because of the efficiency with which the men hunt, game is a regular part of the outstation diet. Weekends, when relatives visit, are.the main times for hunting and we were interested to note that the Aborigines still adhered stringently to the traditional method of cooking kangaroo. Other aspects however of the hunting routine are no longer maintained. Most significantly for example, reptiles were no longer an important part of the outstation diet. The people we spoke to said they did not 'dig for goanna' (although we did notice they were still very skilled at reading tracks). The Aborigines said that people will occasionally take goannas in the summer when the goannas walk about (come out of hibernation) but were generally disinterested in them as a source component of their diet. This disinterest was highlighted for us one day when we passed a blue tongue lizard warming itself in the afternoon sun. We immediately stopped the vehicle so the people could pick the lizard up but this action was only greeted with surprised looks followed by disinterest. This contrasted a similar episode with Pintupi people where we were almost crushed in the rush to catch a lizard before it got away.

\section{Camps and Traditional Land Use}

Consistent with the apparent reduction in traditional land use in the Ernabella region we recorded far less evidence of burning around outstations. The Aborigines said that 'people don't walk around now so they don't light fires' meaning that there is no longer the traditional emphasis on the wide range of bush food once gathered and thus there is no need to burn the bush to maintain high yields of bush vegetables, hunt goanna or localise herds of game. In Figure 7.4 the general absence of burnt ground is quite apparent. This figure reveals only a small stretch of burnt country east of Katjikatjitjara, a larger stretch of country burnt west of Eagle Bore and several stretches of burnt ground further south outside the homeland region.

Accordingly we saw very. little evidence of traditional land use at the different camps we visited. Kangaroos are frequently eaten at camps and we saw kangaroo meat being consumed at David Well and Araluen. We also observed women gathering witchetty grubs at David Well. On one occasion an old man shot a brown falcon (Falco berigora) and took the tail feathers for ceremonial decoration. At Eagle Bore the people were eating a very sour, prickly species of bush tomato (Solanum cleistogamum) collected at camp. 


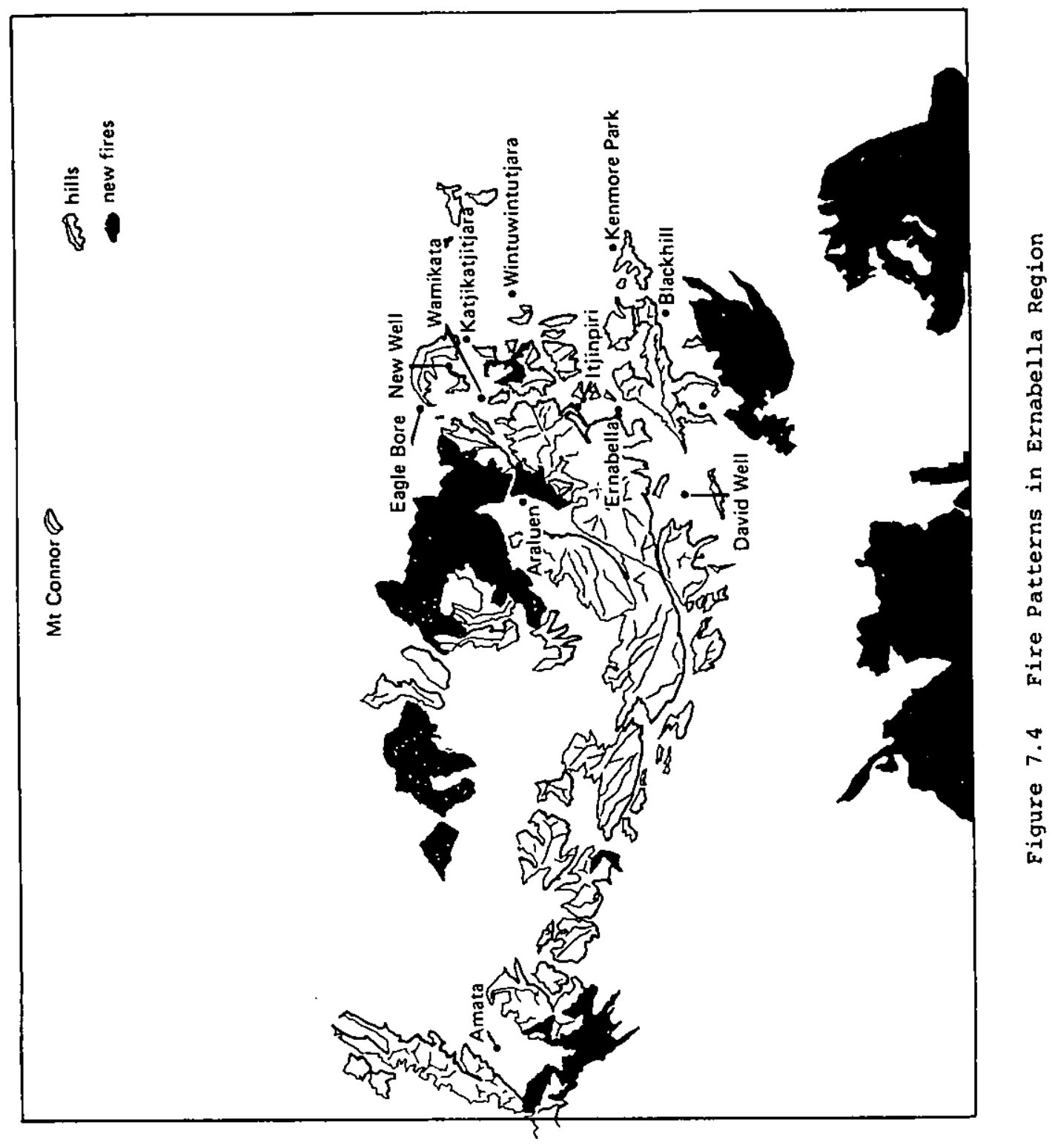


We were also told there are lots of honey ants near Black Hill and that these are collected annually by people from outstations and Ernabella during the end of the wet season.

Supplies of firewood around all the camps we visited were good except at Intjinpiri. In fact the Aborigines said one of the attractions of living on outstations was the abundance of fire wood. Wood is scarce around Ernabella and Aborigines said the quantities brought into the community were never enough to keep everyone warm during the cold winter.

\section{European Land Use}

If we had not included Ernabella in our regional study we would have considered gardening enterprises of the Central and Western Desert outstations a complete failure and treated reviews of the achievements potential of the horticultural developments with scepticism (Mollison 1984; Griffin and Lendon 1979: 7; Brokensha and McQuigan 1977: 121; Coombs 1978b: 37; Coombs et al. 1983:269; Nathan and Japanangka 1983). "However at Ernabella there were established produce gardens which, most importantly, were genuinely desired and cared for by the Aboriginal people. In this region the gardens are quite large (about $50 \mathrm{~m} \times 100 \mathrm{~m}$ in size) and are fenced and laid with drip irrigation. These gardens are essentially the same as those originally established in the Luritja Homelands, and were in fact the model used for those early gardens. Because of this, one is led to ask why the gardens have been successful at Ernabella and not at Papunya or else-where. We felt there were two main reasons for this. In the first place it was apparent that Aboriginal contact with Europeans has been longer - that the Aborigines have become used to a more sedentary life style and, through contact with mission gardens and the local sheep industry, are more familiar with the regular nature of work required to maintain gardens. The people at camps around Ernabella have also been fortunate to have had over 10 years of advice and horticultural expertise from a resident agronomist (Mike Last; see Last 1978; Coombs 1978a:2). Gardens have also been part of the Ernabella Mission since its inception although they have developed to a greater extent since Last's involvement in the region and the funding of a community gardening and reafforestation project by the government in 1972 .

Gardening activities spread to the outstations via experimental work at Katjikatjitjara and now most camps have established their own vegetable plots. The kinds of plants grown are quite varied and we recorded silverbeet, figs, carrots, oranges, lemons, mandarins, mulberries, rockmelon, watermelon, grapes, cabbages, tomatoes, pecan nuts and dates. The most frequently grown crops are grapes, mulberries, oranges and figs.

Among the nine camps we visited all but the newest had gardens. New Well and Araluen for example were not yet set up but nevertheless had very definite plans for establishing gardens. Even camps as recent as Eagle Bore had begun gardens. Here several lines of drip irrigation had been planted with figs, oranges and mandarins. Some of the older camps have more established gardens and at a few camps these are the result of considerable hard work and determination in the face of the environmental difficulties. At Intjinpiri for example, the people have had to establish three consecutive gardens. The first garden was too small. The second was big enough but was washed away by floods.. The third garden is still in existence (Plate 7.5). It is well established and approximately $75 \mathrm{~m} \times 150 \mathrm{~m}$ in size. At Wintuwintutjara the garden is constantly dug up and eaten by rabbits so the people have chosen and cleared a new area where there are fewer rabbits. 


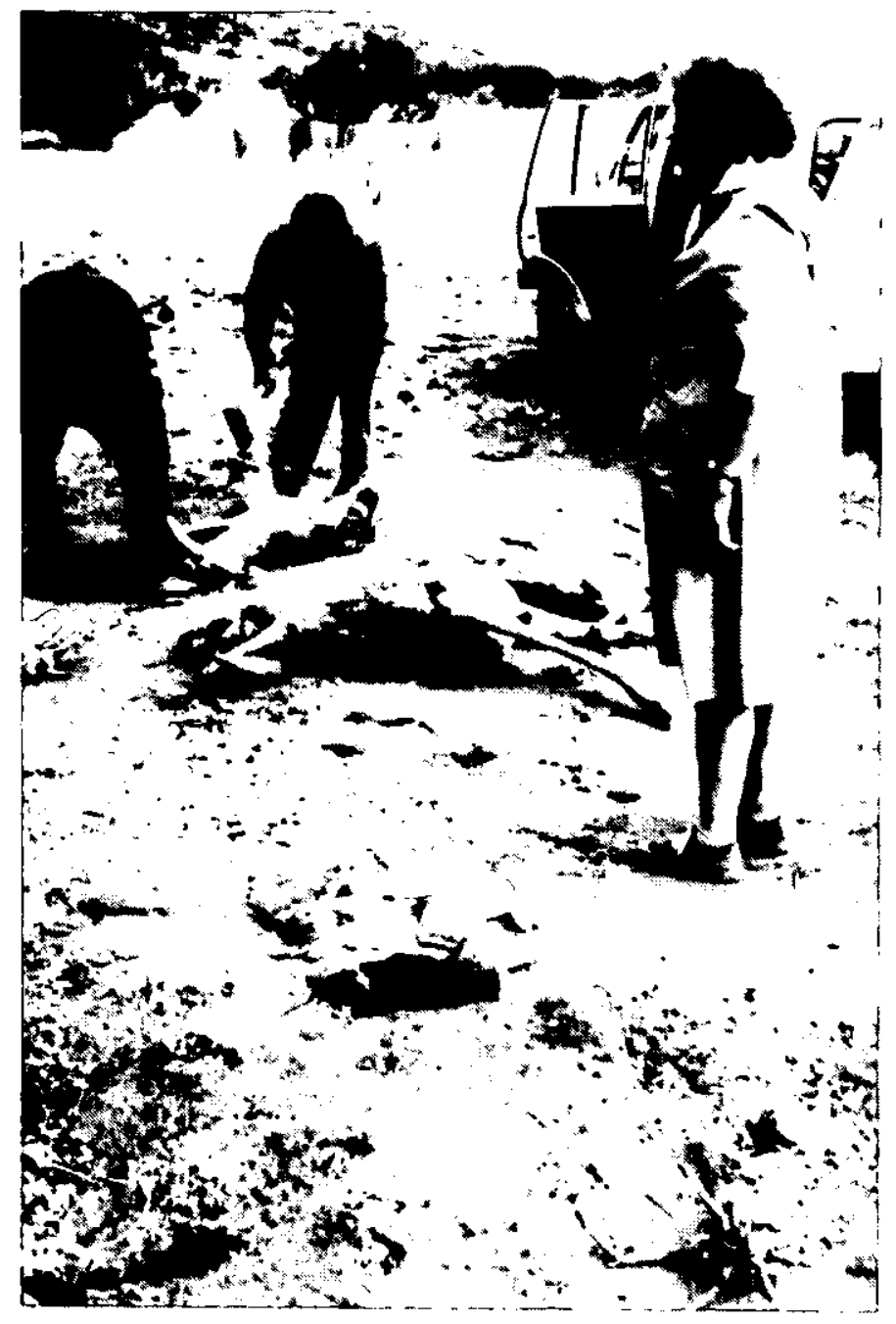

Plate 7.4

Result of an afternoon hunt near Araluen Bore

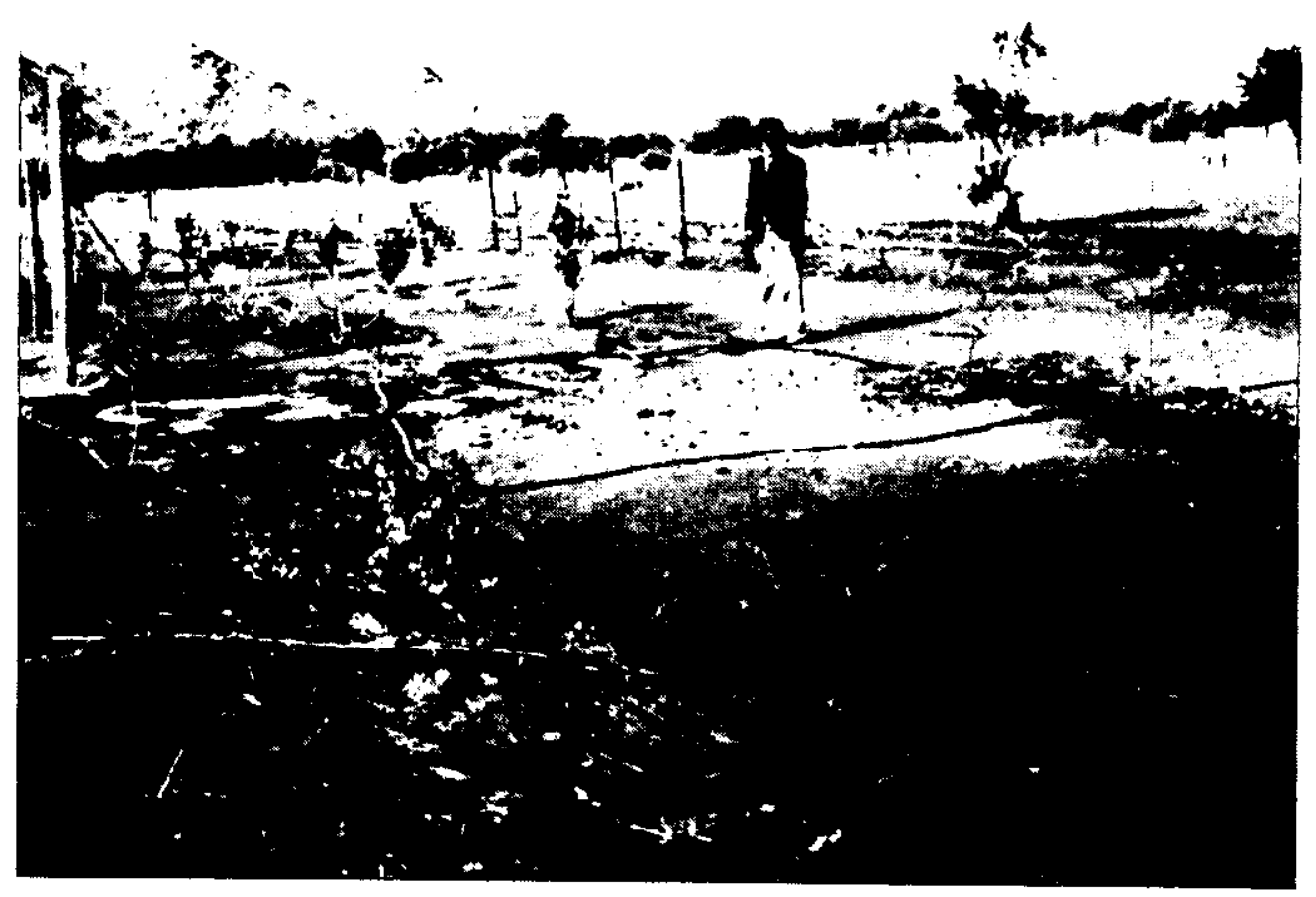

Plate 7.5 Present garden at Itjinpiri 
One of the best known gardens is at Katjikatjitjara. This was the first garden in the region and has remained in use since its inception almost 10 years ago. The present garden is smaller than the original - but still contains numerous oranges, figs, mulberries, peaches and grape trees. The most notable garden was probably at Tjatja. Here an old couple have cleared a large area of ground $(50 \mathrm{~m} \times 75 \mathrm{~m})$ and layed 13 rows of drip lines about $50 \mathrm{~m}$ each in length and planted grapes, figs, oranges, mulberries, watermelons, cabbages, tomatoes and pecan nuts (Plate 7.6). The effort involved in the establishment of this garden is worthy of note as the couple involved are both pensioners and the man has a severely arthritic hip.

Aboriginal concern generally for their gardens was particularly apparent. This was evident each time we were shown around gardens and noticed that the owners straightened sticks, checked drip lines and adjusted grape vines. They were also very firm with children if they were in a garden and we noticed that if the children touched anything they were fiercely reprimanded.

In our opinion one of the most significant aspects of the gardening projects in this area was the prominence of Aboriginal involvement. Each of the gardens we visited had been planned, cleared, fenced, nurtured and maintained by the Aborigines with minimal interference by Europeans.

Most of the crops grown on the outstations are eaten locally but surplus produce, particularly watermelons are sold at Ernabella. The most notable instance of this occurred from the garden at Black Hill. In this case the owner took a truck load of watermelons to an Aboriginal meeting at Kenmore Park, and sold the lot, earning over $\$ 200$ in an afternoon.

Despite our generally favourable and enthusiastic impressions of the horticultural endeavours at camps in the Pitjantjatjara/Yangkuntjatjara Homelands there were also some grounds for concern which should be expressed. For example, we noticed at some camps that some crops appeared to have been grown but not harvested - suggesting to us the selection of crops (either by Europeans or Aborigines) not to the taste of the locals. An example was at David Well. Here rows of silverbeet had been grown but were being left to die. No-one seemed to have any interest in picking and eating the vegetables. We were also surprised that many of the oranges, peaches and mulberry trees growing at some of the oldest camps such as Katjikatjijara and Wintuwintutjara were small (Plate 7.7). This suggested that were only a few years old; whereas the gardens themselves must have been in existence for close to a decade. The implication of this was that the gardens have not always been producing, having possibly been replanted after a period of stagnation and decay. We do not know if this is so, or if so, what the reasons may have been, but nevertheless we felt there was a general lack of expertise for Aborigines to draw on and this may have retarded horticultural practices in the past. Signifying this lack of horticultural advice we noted that most of the gardens were cleared of any litter - thus reducing the long term fertility of the ground and exposing the plant roots to frosts and water Loss. Also vegetables such as cabbage, silverbeet and carrots were not thinned out and the crops were not given adequate protection from the wind and sun. The Ernabella Community does employ a horticultural adviser but he also performs the tasks of outstation Co-ordinator and windmill mechanic. Consequently he does not have time to advise the Aboriginal gardeners adequately. As a consequence the once flourishing community garden is run down and the outstation gardens are 


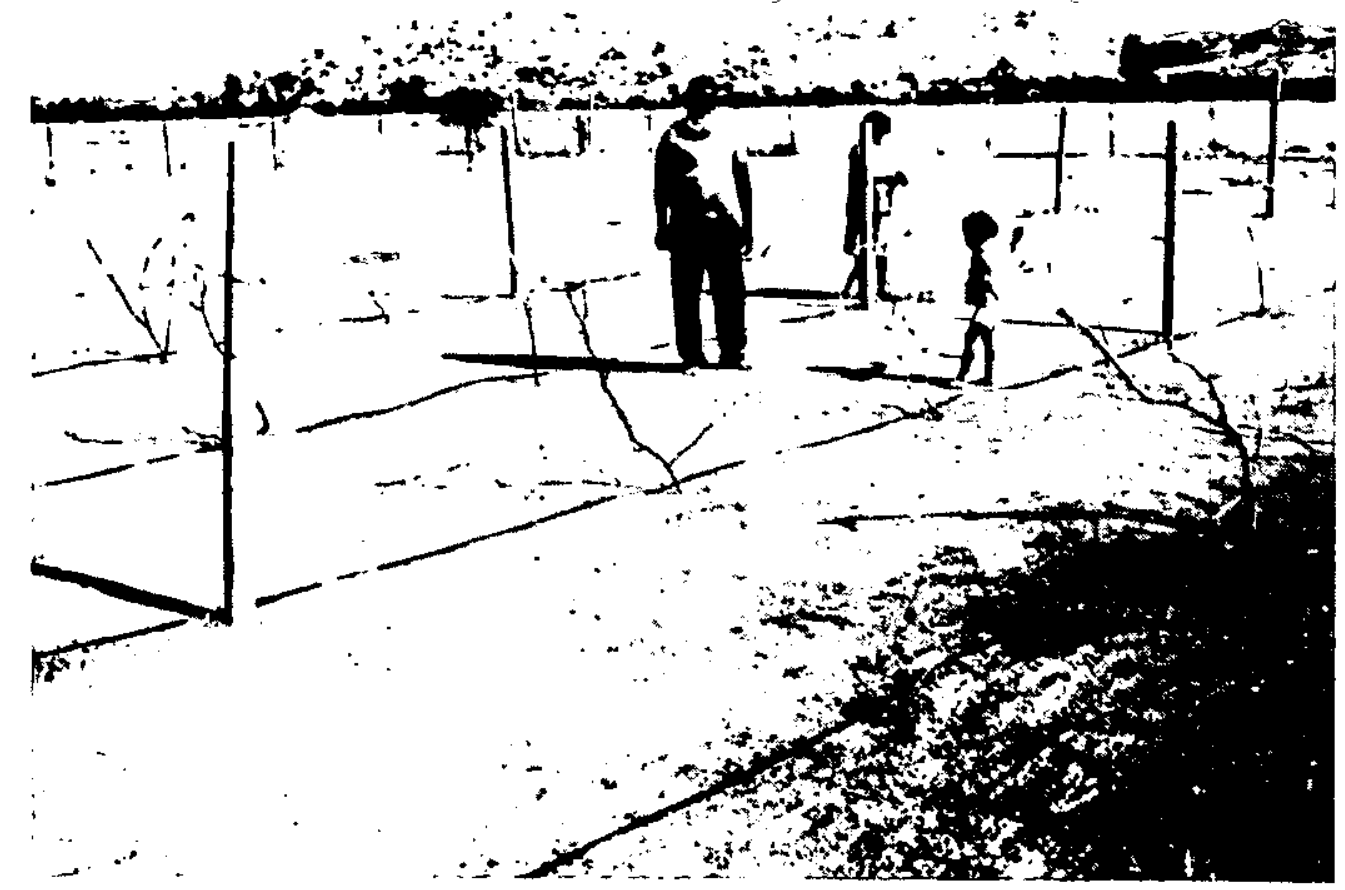

Plate 7.6 Garden at Tjatja

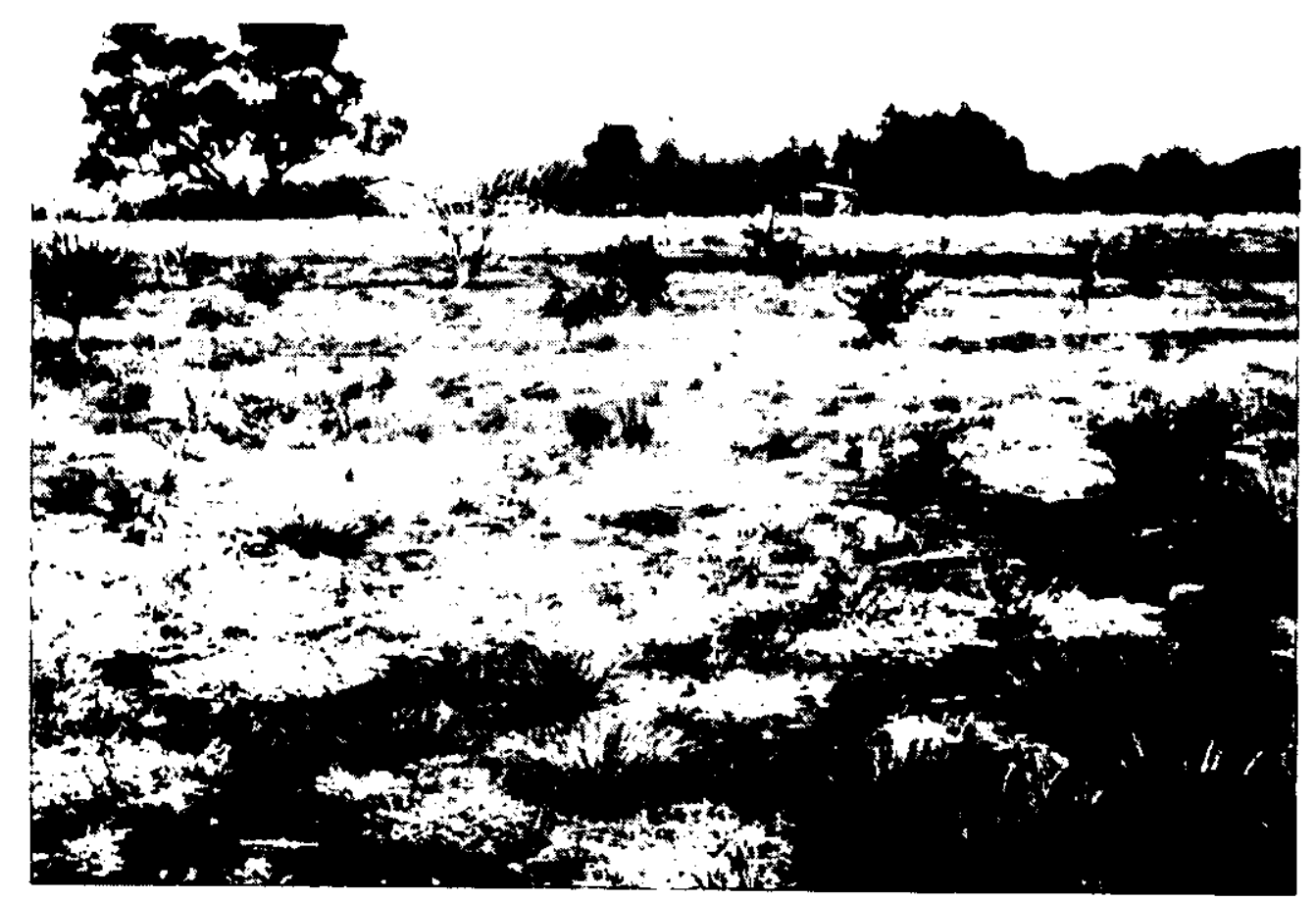

Plate 7.7 Small fruit trees (peaches, mulberry) in garden at Katjikatjitjara 
starting to stagnate. It would seem to us that in this area - where the Aborigines appear to have a genuine aptitude and enthusiasm for gardening, that a horticultural adviser be employed in the region, to advise (not direct) the Aborigines in horticultural methods.

\section{Camp Improvements}

Beside substantial established gardens, many of the outstations also have various fruit and shade trees around the camps. The most impressive camp was undoubtedly Katjikatjitjara, (Plates $7.1 ; 7.8$ ), which is surrounded by an abudance of $4 \mathrm{~m}$ red gum as well as fir trees, cedar trees and castor oil bushes. The people have also planted large windbreaks of cane grass and have even established some lawn around the house. The verandah and fences are overgrown with grapes and, most surprisingly, the people had also planted a garden of geraniums. The overall effect was one of such peaceful tranquillity that Katjikatjitjara is rather well known and is often used as a government show piece. Other camps - such as Intjinpiri have also planted lawn, cane grass and shade trees. In this case the camp is set among two large ironwood trees and is also very picturesque. Some of the newer camps are equally as impressive. At Black Hill for example there are large sunflowers, castor oil trees and shade trees. At David well the Aborigines have planted mulberry trees, cedar trees, fir trees and orange trees.

At all camps we noticed the grounds were well maintained and litter free. The Aborigines receive a small income (equivalent to unemployment benefits) from CDEP funds for keeping their camps in order and this seems to be an effective program. We heard various criticisms of this approach by people who said 'they had never heard anything as ridiculous as getting paid to pick up your own rubbish'. We reserve judgement on this but feel that Aboriginal people are better off getting paid for some activity than just getting 'sit down money' (dole) for nothing. In any case this small payment, in conjunction with the Aborigines' pride in their camps, was effective in keeping the camps in order. As an example of this we recall visiting David Well early one Monday morning. The camp. was in some disarray, littered and generally scruffed about by weekend visitors. However, before anybody left the camp that morning the whole camp was raked and tidied under the watchful eye of the owner.

Perhaps the greatest effort taken to improve the appearance of a camp in the Ernabella region was at Tjatja. Here the old couple owning the camp kept it litter free and had planted three long rows of cane grass for shelter and dust control as well as five mulberry trees, six grape vines, five orange trees, a row of cabbages, 23 exotic trees and 18 red gum trees from a nearby creek.

\section{Arts and $\underline{\text { Crafts }}$}

Some of the people living on outstations were involved in the production of arts and crafts. Arts and crafts were initially begun at the mission in 1948 (Hilliard 1968) with the spinning of sheep wool by Aboriginal women. Since then other forms of craft such as rug making, painting and batik have been encouraged and now batik and the production of wooden artefacts and model animals are well established activities. Most of the wooden artefacts are made from mulga and the animals are made from the roots of red gum trees: Red gum roots are 


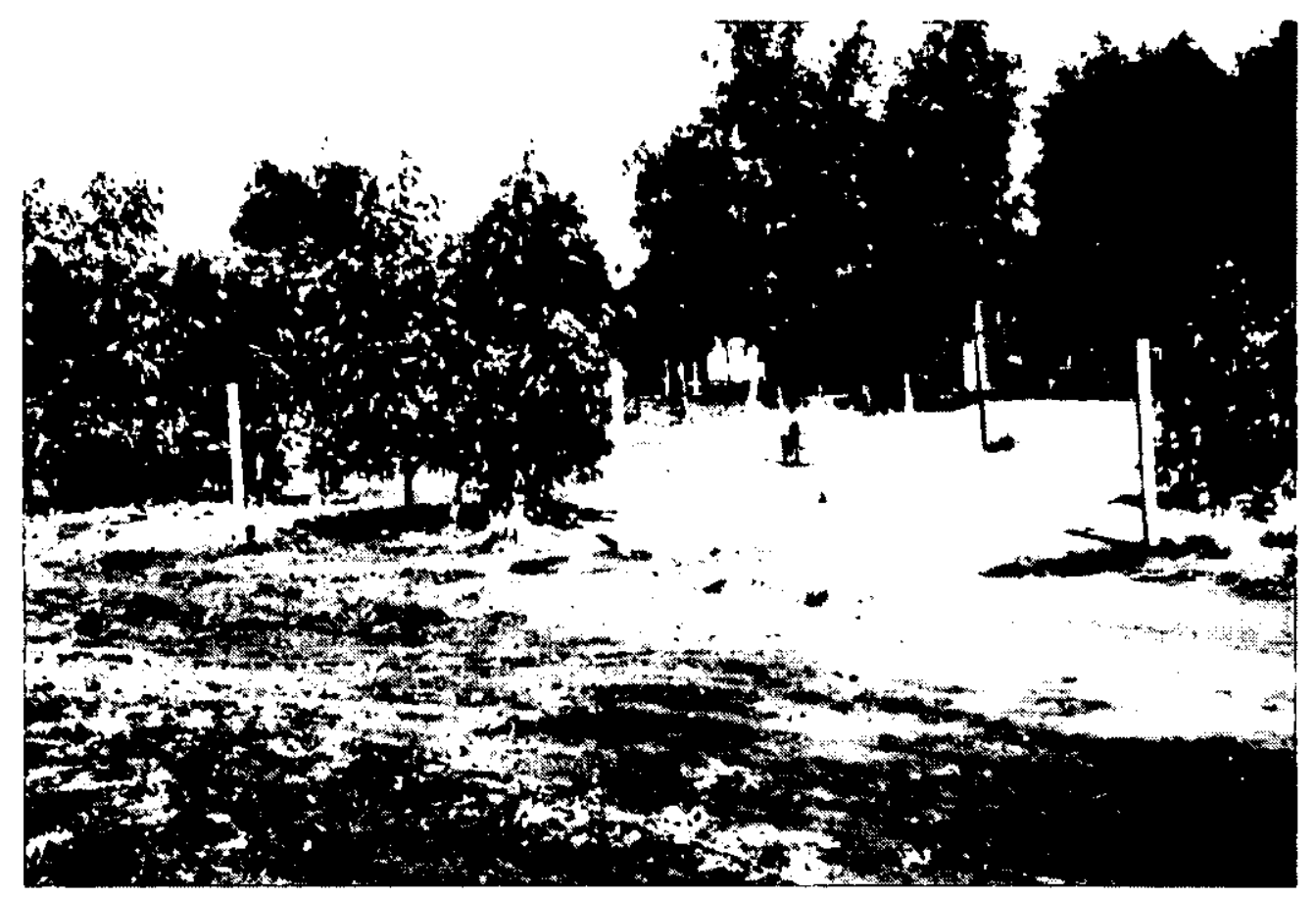

Plate 7.8 Red gums planted around house at Katjikatjitjara 
dug from creek floors and the shape of the animals are cut out with special short handled axes specifically made by the Aborigines. The original roughed out blanks are smoothed with sand paper and the surface is marked with various patterns burnt into the wood with a red hot wire.

We are not sure how many camps are involved in artefact production and the only place we saw this activity taking place was at David Well. Here the men made four boomerangs and the women had made over 30 wooden animals. Apparently there are about 30 women continuously involved in the production of arts and crafts at Ernabella. The crafts are sold through tourist outlets in Alice Springs and at Ayers Rock and this supplies the women with supplementary income and an enjoyable activity. We do not know how much money is actually earnt by individual women but in a comparable situation at Amata about 60-70 people only earn a combined income of $\$ 2,000-\$ 2,500$ a month (Brokensha 1978).

\section{Animal Husbandry}

Ernabella has a strong history of animal husbandry. The mission has grazed sheep since its inception and at the peak of the wool boom in the 1950 s grazed over 5,000 sheep (Dean and Carell 1955). Unfortunately the industry became uneconomic because of crashing wool prices in the 1960s. Before then, Aboriginal people were responsible for shepherding the sheep and many worked with horses and on nearby cattle stations. As a result Aboriginal people in this region have various skills in animal husbandry and these reflect themselves in some of the aspirations and activities of outstation dwellers.

At David Well, for example, the camp boss was originally a horseman. He is partially crippled and has a wooden leg but nevertheless has several ribbons won in local shows for his horse riding skills. His skills have been incorporated in the development of his outstation and the camp includes a horse yard and he has almost completed fencing of $\mathrm{a}$ large valley $1 \mathrm{~km}$ north and south of the camp to run horses. Twelve horses are currently stabled at Fregon and will be taken to David Well as soon as the fencing is finished. At Wintuwintutjara the people have, enclosed a large area around their camp with steel droppers and are in the process of wiring the fence to keep sheep. They have asked the community council for some money under the CDEP program to buy a small flock. Similarly the people at Araluen are planning to run sheep when their camp is re-established. Araluen is located in what used to be a major grazing area and remnants of old shelters belonging to early Aboriginal shepherds are scattered through the area.

Perhaps the most enterprising of the outstation people in this regard is the owner of Black Hill. Two years ago he brought 200 wethers in Port Augusta for $\$ 3$ a head. He transported them to Ernabella for $\$ 4$ a head and sold them at the community for $\$ 50$ a head; thus making $\$ 8,600$ profit on his original investment of $\$ 1400$. At present he is running horses and cattle belonging to Ernabella and is charging the community an agistment fee. He is also doing a fencing contract for Kenmore Park and has asked to be paid in wild horses. He is an aged pensioner and, in conjunction with the achievements of the man from David Well, the pensioners from Katjikatjitjara and Tjatja, give forceful insight into the possibilities and potential of the outstation movement if Aboriginal people are given an opportunity and if economic, social and agricultural projects are geared to capitalise on Aboriginal skills and interest. 


\section{Chapter 8}

\section{The Overview}

The outstation movement in the homeland regions around Papunya, Yuendumu, Docker River and Ernabella began with the Pintupi movement west from Papunya in the late 1960s. Early decentralised movements were being promoted by missions (Fregon 1961) and Government (Amata 1961, Docker River 1969) about the same time although the movement as inspired by Aboriginal people did not really establish itself until early 1970 . The homelands movement in Central Australia paralleled movement elsewhere in Australia, for example at Maningrida (1972: Meehan 1979), Caledon Bay (1970) and Sunday Island (near Derby 1970) (Gerritsen 1982:63). By 1975 there were major outstations set up in Central Australia west of Papunya (Yai Yai and Kungkayunti). By this time outstations were also being talked about and planned in other regions, and the movement began at Ernabella and Yuendumu in 1976, at Docker River in 1977 and extended west from Papunya, past Kintore in 1981. Throughout its short history the movement has grown vigorously and there are now official records and population figures for 100 camps in the desert areas (this excludes camps around Alice Springs, and includes homeland areas around Hermannsburg, Utopia, Warburton, Amata, Indulkina, Pipalyatjara, Fregon, Haast Bluff as well as the five areas $v$ isited in this project). The combined population of these outstations is officially 2431 people (DAA file 78/777; 1983) and although we cannot vouch for the accuracy of these figures (see below) they give some idea of the scale and momentum of the homelands movement. In the regions we worked in the growth of the homelands movement has been equally dramatic. For example in 1975 only five outstations were in use in the general region. By 1980 this number had jumped by 36 to 41 camps. By 1984 another 31 camps had been established, bringing the total to over 70 homeland camps in the western Desert.

The motivation for this homeland movement has been well documented (Meehan 1979; Brokensha and McQuigan 1977; Downey 1980; Coombs 1974, Coombs et al. 1980; Griffin and Lendon 1979; Latz and Griffin 1978; Kimber 1983; Lat 1983 ). Our field work confirmed the general trend of these observations; that people wanted to return to their own country and wished to 'look after' traditional country, needed to look after places of religious importance, wished to return to a more traditional and independent lifestyle, wanted to remove themselves from the social, racial and religious pressures of community life (particularly with regard to the problems of alcohol and juvenile petrol sniffing) and to have more immediate access to natural resources such as bush food and firewood.

Not surprisingly perhaps none of the Aborigines stressed the materialistic benefits of outstations - such as the possibility of obtaining a small house or more significantly of obtaining a toyota. This kind of motivation was stressed by some Europeans with whom we had contact. We interpreted this view as over-cyncial and have no evidence to suggest that this is a major driving force behind the outstation movement. We do not think our belief in the basic honesty with which the Aborigines explained their ideological desires to live on outstations to be naive. We could find no evidence in our region of study for the belief that 'outstations are one card in the competitive game of gaining access to resource distribution that so occupies Aboriginal leaders' (Gerritsen 1982:64). However we do consider that materialistic designs play a part in the establishment of some outstations. This would seem to have applied to some of the 
outstations we visited which were abandoned and had a poor record of permanency (see Wallace and Wallace 1977 for graphic example). Nor do we see a possession of material goods - again the toyota can be highlighted as really important in the long term acquisition of status and prestige within communities in the Western Desert. Such an interpretation reflects a basic misunderstanding of the cultural basis of politics and Aboriginal life in this area (Myers $1980 a$ and b). Here, it is not so much what you have but how you use it for the benefit of others. In this region for example it is not uncommon for people to reject houses or get rid of vehicles because of the never ending social responsibilities attached to their ownership. In one recent example a man we worked with bought a video for his family. For the next week his house was full of children day and night until in despair he gave the machine away. He received no status or prestige by owning this valuable material possession. In the Western Desert a toyota is no substitute for owning country that contains valuable resources and ceremonial sites or having a detailed knowledge of the law or being able to speak English.

Having said this however we should not underestimate the importance of material possessions in the development of outstations once they have been established. We were often confronted with frustrated camp owners who had 'been waiting two years for bore and still nothing'. Of interest however was that most of the anxiety was invariably over the need to obtain permanent water - not toyotas.

Generally we felt such pre-occupations with facilities stemmed from the genuine desire to obtain basic facilities and thus make outstations habitable. Apart from this, however, there is also a tendency among some Aborigines to ask endlessly for European goods. This, however does not reflect an essential materialism in the outstation movement. Rather it is the result of three things. One, as Elkin explained is that 'white and native are foreigners to each other, getting what they can from each other, but sharing little' (1967:56). We recall on one occasion at a housing meeting at Ernabella where one man demanded a three bedroom house with air conditioning, carpets and various other additions. Such a claim was completely out of step with the nature of the meeting and may have resulted from an aggressive bitterness towards Europeans manifesting itself as a genuine desire to milk what he could out of them. Alternatively the man may have been attempting to prove his leadership qualities and his prowess as a spokesman in front of the assembled Aborigines. But it may also be that he, like so many Western Desert people simply does not understand what is a fair thing or 'how much is enough' in European terms. Myers (1980b:2) considers precisely 'this uncertainty underlies much of the claim-making that went on towards whites' in contemporary Pintupi society. This problem is exacerbated by a seemingly never ending stream of government officials, academics, task forces, and irresponsible visionaries who cannot say no, who cannot explain the financial, administrative and political realities of the day and, worse, are forever telling the Aborigines they have been cheated, what they need and what they should get. Under these conditions how can Aboriginal people really judge what is a fair thing and equate their expectations with what they receive?

The point being made here is that by and large the homelands movement reflects the desire of Aboriginal people to improve the social and religious conditions of their lives and to 'look after' their traditional homelands. We can see that materialism and political ambitions are contributing elements to the movement but recognize the cultural basis for the homelands movement as the overriding factor explaining the development of 
the movement. Because of this we believe the movement has substance and if given the initial support it requires, will establish itself very securely and will be here to stay.

Mobility and stability

\section{Population}

The first and most apparent observations we made of the population in the homeland regions visited was that the number of people living at many outstations was significantly lower than official records held by DAA and/or the local communities. For example the recorded total number of people on outstations in the region studied varied between 702 and 747 people, whereas we only counted between 398 and 410 people; 55 per cent of the official total (Table 8.1). This large discrepancy is primarily the result of the total absence of people at outstations in the Pitjantjatjara/ Ngaanyatjara Homelands, whereas the official figures were high (between 377-322 people). In the other area the recorded population figures were about three quarters those of official records; the closest figure being in the Pintupi Homelands and then the pitjantjatjara/Yangkuntjatjara Homelands, the walpiri and Luritja Homelands. This raises a number of questions. For example, do these figures reflect an inherent weakness in the outstation movement? Do they reflect the fact that people claiming they are living on outstations are not doing so or do they mean that people indicating they intended to live on an outstation have not done so? Do they reflect that there are no longer as many people living on outstations as when they were first set up? Alternatively are the original population data unreliable; exaggerated by Aborigines and/or Europeans staff (wittingly or unwittingly) to highlight the success and momentum of the movement in their particular regions or are the official figures simply the result of population projections, taken for fact, of the number of close relatives which would be entitled to live at the site if they chose?

Table 8.1

Comparative number of people recorded at outstations visited official record Field record of official total

\begin{tabular}{lccc}
\hline Pintupi & $84-89$ & $64-69^{\star}$ & 77 \\
Luritja & 241 & $79-89$ & 63 \\
$\begin{array}{l}\text { Walpiri } \\
\text { Pitjantjatjara/ }\end{array}$ & 245 & 180 & 73 \\
$\begin{array}{l}\text { Ngaanyatjara } \\
\text { Pitjantjatjara/ }\end{array}$ & $277-322$ & 0 & - \\
Yangkuntjatjara & 100 & $75-77$ & 77 \\
Total & $702-747$ & $398-410$ & 55 \\
\cline { 2 - 4 } & Note $*$ excludes Kintore
\end{tabular}

Alternatively, is the discrepancy merely the result of the short term nature of our survey? Had we spent more time in each region would the population levels have appeared different? We do not think so and consider our figures generally representative of the population figures for outstations at any point in time. Possibly a combination of the factors out- 
lined above account for the absence of people on camps but there is also another important factor - the high mobility of desert Aborigines. With regard to the former possibilities however we consider that the official population figures for Docker River are exaggerated and that there are no longer the same number of Aborigines using the camps as when they were first established. Similarly the population figures for the Luritja Homelands have fallen - with many Pintupi people leaving the area and moving to new camps around Kintore. Apart from these specific instances we believe population mobility accounts for the noticeable discrepancy between the official figures and ours.

Nomadism is a strong cultural characteristic of Western Desert Aborigines. Traditionally these people lived in a harsh environment, where water resources were pitifully small. The people had to walk great distances to survive and for social and ceremonial interaction with other widely spaced groups of people. Gould (1969) for example believed the Western Desert people were the greatest nomads in the world and research by Cane (1984) recorded people travelling distances of up to $700 \mathrm{~km}$ on foot for ceremonial purposes. That same characteristic pervades Aboriginal society today. The region is still sparsely settled and there are less than 5,000 people (DAA file 78/177) in an area of at least $300,000 \mathrm{sq} \mathrm{km}-$ greater than the size of victoria. With the assistance of toyotas and good roads people are still very mobile, travelling for precisely the same social, economic and religious reasons as in the past. In fact during our study over half the camps visited (64 per cent) were unoccupied (Table 8.2) a figure which no doubt explains some of the discrepancy between our record and the official record of people normally using camps. Some of these camps, particularly those near Docker River appear to have been virtually abandoned but the majority were only temporarily vacated.

Table 8.2

Number of camps in use in the homelands visited

Homelands

occupied

Unoccupied

Abandoned

Total

No. 8

No. 8

No. o

$\begin{array}{lrrrrrrr}\text { Pintupi } & 5 & 83 & 1 & 17 & 0 & 0 & 6 \\ \text { Luritja } & 4 & 33 & 4 & 33 & 4 & 33 & 12 \\ \text { Walpiri } & 8 & 62 & 3 & 23 & 2^{*} & 15 & 13 \\ \begin{array}{l}\text { Pitjantjatjara/Ngaanyatjara } \\ \begin{array}{l}\text { Pitjantjatjara/ } \\ \text { Yangkuntjatjara }\end{array}\end{array} & 0 & 0 & 1^{* *} & 8 & 12 & 92 & 13 \\ & 7 & 78 & 2 & 22 & 0 & 0 & 9 \\ \text { Total } & 24 & 45 & 11 & 21 & 18 & 34 & 53\end{array}$

Notes: * Tjulpungu and Puyurru may not be completely abandoned.

** Puntitjarta showed some sign of recent occupation.

During the course of our field work there was a great deal of movement associated with ceremonial activities. Most of this was focused on Docker River - with people travelling from outstations and communities at Kintore, Yuendumu, Balgo, Papunya, Pipilyatjara, Wingelina, Kalka and Ayers Rock to attend ceremonies there. There seemed to be a great revival of 'business' activities in the Western Desert associated with the homelands movement and 
we would expect this resurgence to continue - increasing the general mobility of people living on outstations during the next few years.

Economic necessity was also a major reason for people moving about. People at more traditional camps spend much of their time away from camps hunting and gathering. Often people from outstations worked at near-by communities (as health workers, office personnel, community councils, schools and in one instance as a pastor) and also travel frequently to obtain food and petrol, send their children to school and to get health care not available at the camps. Mobility of this kind was greatest at camps nearest communities and in homeland areas surrounding Ernabella and Yuendumu where the people still have close economic and social ties with the community. This was particularly evident at Ernabella where most outstations are within $30 \mathrm{~km}$ of the community.

Social activities are also a big part of personal mobility between individual outstations and outstations and the main community. Social activities includes visits to children, close family and friends living in communities, travelling to participate in and watch sports matches, watch video and go to church. Such mobility is often most pronounced during weekends; when camps can be vacated as people travel for sporting and church activities.

The combination of these factors, in conjunction with the distances travelled can mean outstations are vacant quite a lot of the time. This does not mean however, that the Aborigines 'never bloody use them' or that the professed attachment to country and obligation to the 'dreaming' is a sham. Distances are very great and thus the Aboriginal people in this region have to travel extensively to fulfil social and ceremonial obligations and to obtain basic economic necessities. By doing so Aborigines are reinforcing their responsibilities to their cultural heritage, not negating their commitments to it.

Population stability, however, is a slightly different issue. We recorded 18 camps ( 34 per cent of the total visited) which gave the appearance of being abandoned. We are hesitant to describe any of these camps as completely abandoned - inferring they will never be used again, because such a population seems unlikely and obviously we cannot see into the future. The camps classified as abandoned, however, certainly appeared to have been deserted for a relatively long time (3-6 months). Most of these camps (12) were located around Docker River; and these make up three quarters of the 'abandoned' camps recorded. It is hard to believe that in this area none of these camps will ever be reoccupied, and we understand that some camps were back in use several months after we left the region (Kalotas pers. comm., Kenttish pers. comm.) - but whether this was due to the arrival and residence of a DAA official at Docker River at the time or not we are unable to judge.

Other camps however, which seemed abandoned are unlikely to be reoccupied for a long time. Ili Ili for example, in the Luritja Homelands, has a history of instability and there is nothing to suggest this will change in the near future. In the same region Warren Creek and Ilpili will remain unoccupied as deaths have driven people from both camps. Five Mile alcohol related instances have destabilized the camp and this is also likely to have a lasting effect. Other camps such as Puyurru and Tjulpungu which were recorded as abandoned have only been abandoned because of lack of water. Once good water is found it is likely that the camps will be reoccupied. 
Historically the outstation movement throughout the region has been relatively stable. The Luritja experience, however, is an exception. Here the movement was destabilised by a whole range of factors; deaths at camps, shortages of water, alcohol, sorcery (see also Kimber 1977), but primarily because of the movement of Pintupi people through the homelands towards Kintore in the late 1970 s and early 1980s. This appears to have caused a major dislocation to the Luritja movement but it has now passed and the outstation population appears to be in the process of re-establishment and consolidation. At Docker River the movement started securely but has recently broken up. Possible reasons for this were discussed in chapter 6 and briefly included; involvement in 'business' activities at Docker River, that people had returned to the settlement having lost the original euphoria of returning to their traditional land, that outstations were too cold, that people now preferred to live at the settlement because of the available facilities and that the movement had been stifled by too much European involvement. We consider the problem in this area to be of importance and suggest it is worth further investigation, so government bodies can recognize the symptoms of instability in the future and thus help to avoid them. The remaining regions visited appear to have remained relatively stable throughout their history.

An independent issue which is likely to effect the stability of the homelands movement over the next 10 to 20 years is the continued movement of Aboriginal people further into their traditional homelands both as a result of people's desire to return to their own country and as internal pressure is applied by individual linguistic groups who wish to claim land currently occupied by people from other regions. Exploring the first issue further, we would not be surprised for example if Kintore, while remaining a resource centre, experiences a drop in population as people move west to Wala Wala (Kiwikurra) and north and west towards the Kimberleys and Pilbara. We would also expect to see a similar occurrence at Nyirrpi as northern Pintupi leave that community, and move west towards their traditional country in the vicinity of Lake Hazlett. Similarly individual camps such as Yumurrpa (Walpiri), Alkipi (Luritja) and Tjukula (Pitjantjatjarra/Ngaanyatjarra) may be vacated or become smaller as people move towards more traditional country. Figure 8.1 represents an approximation of the location of outstations so far estabi ished in relationship to the Western Desert region. Examining this figure it is immediately apparent that large proportions of the Western Desert are yet to be resettled. Given the extent of this region we can see no reason why Aboriginal people from both existing outstations and communities in the kimberleys and Pilbara will not move back and occupy this country eventually. Historically the tendency amongst these Aboriginal people has been to move back to old country, despite what they may say. For example, when the Pintupi first established yai yai they were 'adamant' that they did 'not want to go back to their own country' (Coombs 1974:138). Whether this was because the Pintupi could not foresee the possibility of obtaining services and facilities in such remote country - or whether they were attempting to appear resolute after previous outstation failure is unknown. Nevertheless during this era people from Amata and Pintupi from Docker River and Warburton were preparing to return to traditional country. Coombs $(1974: 138)$ felt that it is hard not to believe that if adequate facilities.were available there, (further west) some of the Yai Yai group would not move also'. There were 250 people at Yai Yai then (the same population as at Kintore now) and as history reveals Yai Yai was abandoned as soon as there were facilities closer to Pintupi country.

Exploring the second possibility we can foresee increasing pressure building up within certain linguistic units to remove 'foreigners' from 
Figure 8.1

Approximate distribution of camps

in the Western Desert

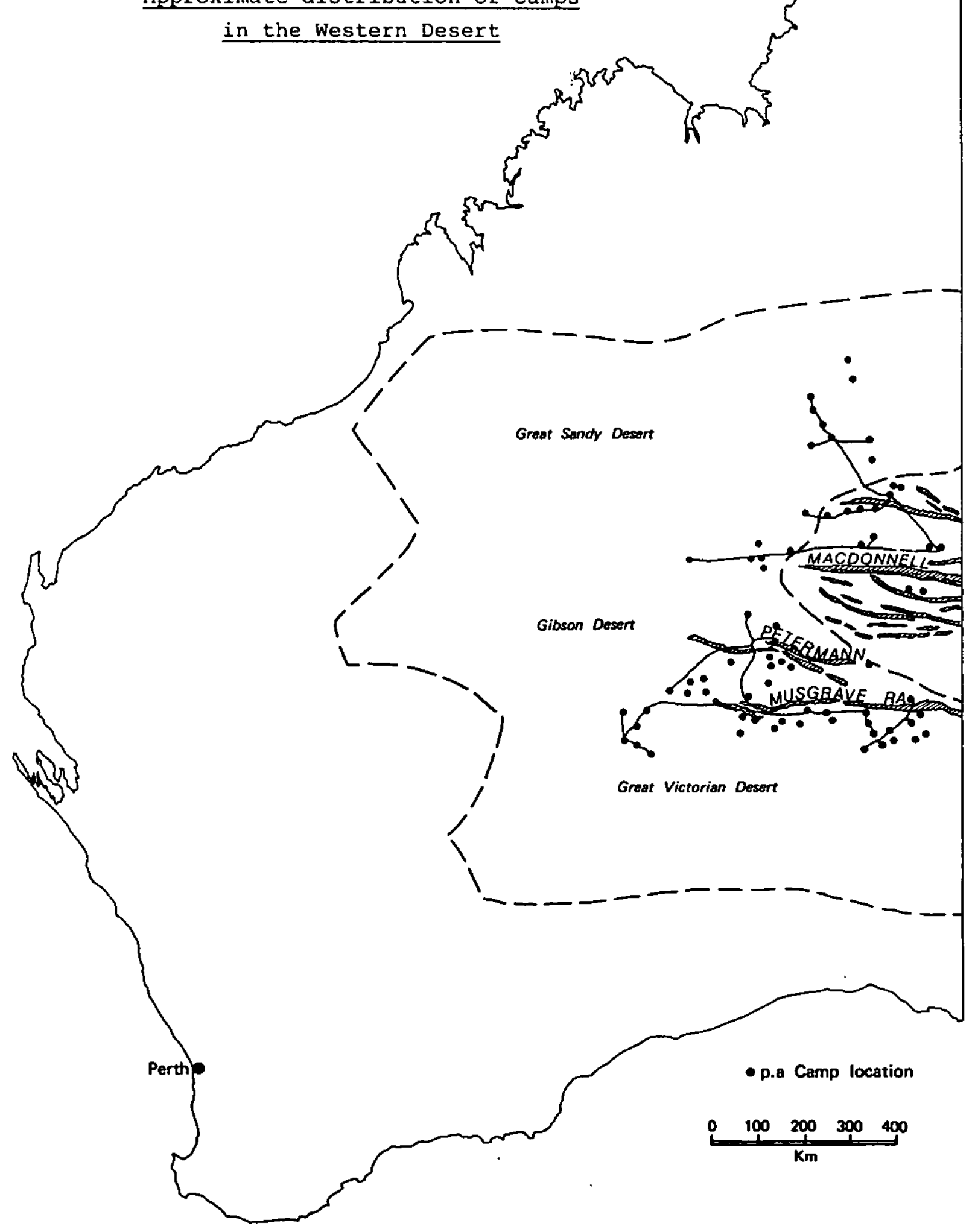


country which does not really belong to them. We can see this occurring as more people seek to establish and own outstations within regions that are more or less fully occupied. In this instance we are thinking specifically of New Bore, Black Water, Alkipi, Ilpili and Warampi in the Luritja Homelands (which are not occupied by traditional land owners and/or Luritja men); and David Well, Eagle Bore and Tjatja on Yangkuntjatjara country. In the latter case there appears to be some resentment by Yangkuntjatjara people of the dominant Pitjantjatjara presence in their homelands. Whether this resentment will develop and destabilize the settlement pattern in this region remains to be seen although we would be surprised if any major upheavels occurred given the long Pitjantjatjara association and attachment to the country around Ernabella.

With the exception of Docker River, our overall impressions of the homelands movement however at the time of our visit was one of optimism. We suspect minor disruptions to the movement will continue to be caused by water shortages, deaths, alcohol, arrival of new toyotas but on the whole we see the movement developing steadily and securely. We consider the question of land ownership and expanding settlement patterns requires further consideration and detailed investigation by skilled anthropologists. Clearly, before government bodies can plan for the future, they must have some clues as to what the future may hold. Thus, the Aboriginal people must be consulted and their intentions clarified so the government can make an informed decision as to whether to fund existing resource centres as growing communities, or use those funds to grade roads, and provide facilities at future outstations. The government thus needs to monitor the homelands movement carefully, identify patterns in its development, and to gather reliable data so it can facilitate the smooth and cost effective growth of the movement in the future.

\section{Population Structure}

In comparison with other Western Desert communities the composition of the outstation population is quite unusual. Using Yuendumu as a typical example (Young 1981) one finds that population distribution for an Aboriginal Community closely resembles that of less developed countries. They have relatively high proportions of young people ( 37 per cent), high proportion of middle aged people ( 56 per cent), and a low proportion of old aged ( 7 per cent). The composition of the outstation population at the camps we visited was markedly different. Here there was a lower percentage of children (28 per cent) and middle aged people ( 40 per cent) and an exceptionally high proportion of old people (32 per cent) (Table 8.3). A high proportion of old people is a typical characteristic of outstations (Latz 1982:163; Young 1981:71) but we should stress that this proportion is unusually high by any standards. For example it is much higher than for the Aboriginal population in Australia generally or the Australian population itself. In fact it is higher than in any other geographic region in the world (Nortman and Fisher 1982). The reasons for this are fairly obvious; the outstation movement is an old peoples movement. They hold the traditional knowledge, most of the authority and have had the strongest desire to return to traditional country. The absence of young people is explained because many of the children.live in communities so as to attend school and young adults work and/or seek entertainment and companionship at the communities.

The implications of this population imbalance on the future of the outstation movement are worth considering. The most obvious implication of so many old people at camps is that during the next 10-15 years many will 
die, thus causing numerous camps to be vacated for an extended period of mourning, causing a prolonged era of instability. Secondly, once this old generation of 'bush people' pass away one must consider whether the new generation of old people, reared on settlements, are going to like living the spartan outstation 1 ife that exists at present or whether they will prefer to live on settlements where there are more services and comforts. Alternatively the next generation old people may acquire as much knowledge of law and the bush as the former generation and thus want to continue living on outstations but with improved living conditions; housing, sanitation, reticulation, sewerage disposal, water quality, electricity, health and education. Furthermore one must consider how todays young - the third generation from the pristine traditional life, are going to view the prospect of outstation life. Are they going to prefer the food, sport and entertainment facilities of the communities - or seek the neo-traditional lifestyle of the outstations. Are they going to wish 'to live in style like a white man' or seek their independence and cultural heritage in the homelands. In other words, once the old bush people die will the homeland movement die too?

Table 8.3

Age structure of people recorded living at camps visited compared to age structure at Yuendumu (after young 1981)

Age group years

Yuendumu \& Camps recorded \&

$\begin{array}{lrc}0-14 & 37 & 28 \\ 15-59 & 56 & 40 \\ 60 \text { and over } & 7 & 32\end{array}$

As a general rule we do not think this will happen. This has not happened elsewhere in Australia where European impact on Aboriginal society has been longer (e.g. in Arnhem Land (Meehan 1979), nor has it happened in other countries - for example the Canadian north west (Asch 1982) or African south (Lee 1979). Symbolising this Lee observed

Hunting is real. Hunting exists and hunting and gathering economies exist and this is to me a new fact in the modern world because twelve years ago at the Man the Hunter conference we were writing an obituary on the Hunters (in Asch 1982).

Instead of the extinction of Aboriginal culture we would expect Aboriginal spiritual and economic attachment to the land and the outstation lifestyle to continue. We would also expect that, as Gerritsen (1982:62) predicts, the 'next generation of outstation leaders will not be as spartan as the present generation' and because of their experience on communities and observation of Europeans, will demand better facilities and better services. To a certain extent we see this pattern establishing itself now where the less traditional people living at outstations around Ernabella expect more sophisticated facilities than those more recently removed from the bush such as the Pintupi. The Ernabella people, for example, are not satisified with tin sheds and want little besser brick homes. Nor are they satisfied with camp fires for warmth and cooking but prefer electric light, gas ovens and heaters. Nor are they satisfied with a handy spinifex bush - 
preferring instead toilets and septic tanks. They will not accept the provision of one hand pump to be shared by 30 people - but expect taps in their houses and adequate showers and ablution blocks. Nevertheless despite these sophisticated elaborations the outstation movement around Ernabella is very strong and traditional values are still very significant. If Ernabella is any sort of model for the future one may find that, rather than seeing traditional culture die out, the Aborigines will redefine and strengthen the traditions they value in the light of what European society has to offer. At outstations in this region we perceived a rationalisation of the values offered by both cultures emerging as a (conscious or subconscious) attempt to incorporate the best of both the Aboriginal and European worlds into their own. This has not occurred to the same extent in Pintupi society, but there is 30 years of European contact separating the Pintupi from the Pitjantjatjara at Ernabella. Falling between these cases are the Walpiri, Luritja and Pitjantjatjara outstations at Docker River. These people seem in a state of flux - where they are as much in the process of rediscovering their own culture as they are rationalising the potential benefits of the west.

If we have understood this pattern correctly then one can define a continuance of change from the Pintupi, through the Luritja, Walpiri, Pitjantjatjara and Ngaanyatjara at Docker River to the Pitjantjatjara and Yangkuntjatjara at Ernabella, emerging from the duration and nature of contact with Europeans. If this model is true then one should be able to predict the likely developmental stages of respective homeland regions according to their particular pattern of contact with Europeans. For example we would expect the outstations around Utopia to be the most like those around Yuendumu, and those at Hermannsburg to be most like those at Ernabella - although given the longer contact history at Hermannsburg their outstations may well be even further developed. The contact of Aborigines in Arnhem Land has been even longer and we would expect these to be even more sophisticated and for these people to have more effectively defined the respective roles of European and traditional culture in their own lives. Because of this juxtaposition of cultures by Aborigional people what may be called acculturation by choice rather than coercion - we expect the outstation movement to survive. With regard to the future of the up and coming young on outstations we would agree with the following observation by Coombs :

\begin{abstract}
If I understand them (Aborigines), they believe that given the security of the homeland context and the confirmation in the Aboriginal way which it may make possible, the young will grow up capable of making use of what white society of fers but being essentially uncorrupted by it; being able to take over the most useful items of its technology, to turn to it for occasional excitement and stimulus but remaining able and happy to return to their own way ... This may be an optimistic expectation and may underrate the meretricious charms of the beer and coca-cola civilisation but it derives from perhaps the only strategy which stands a chance of preserving continuity for Aboriginal society (Coombs 1979:7).
\end{abstract}

\title{
Facilities
}

In this report we have attempted to characterise the facilities available at outstations and thus provide a regional picture from which it may be possible to assess the likely developmental trends on outstations in 
the future. This characterisation is based on Aboriginal expectations of the facilities they need compared to the facilities that we recorded on outstations visited for this report. It was our impression from talking to various Aboriginal people that the basic requirements of almost all the people living at camps in the region studied was to have a bore, equipped with at least a hand pump, have a 2 way radio, an ABTA funded vehicle per camp and have one first stage house per family (or per five people generally). We have called this range of facilities 'standard' equipment - not so much because it is the standard range of gear found on outstations but because it seemed the standard expectation of most people we spoke to. At outstations at which any of these basic facilities were missing we described as 'substandard' and conversely camps with extra equipment were referred to as 'superior'. Obviously such terms are only intended to have broad applicability and do not describe every situation accurately. For example, there are no first stage houses in the Pitjantjatjara/Ngaanyatjara or Pitjatjantjara/Yangkuntjatjara homelands and in these instances one must assess their equivalent in terms of this system of classification. Furthermore, some camps, such as Black Hill - do not meet the specific requirements of the 'standard' category, yet have other facilities, such as a diesel pump, large steel shed, stock yard, solar heating, electricity, extensive reticulation, which are 'superior' to other camps which do meet the 'standard' criteria. The particular details of each region are described in relevant chapters so here it is sufficient to describe the general regional picture.

Table 8.4 represents the numbers of camps at which we attempted to classify the range of facilities recorded (the table excludes five camps in the Luritja Homelands and all the camps in the Docker River region as these appeared to be abandoned at the time of our visit; we should note however, that the majority of camps in the Docker River region were well equipped by regional standards). From this table it is apparent that only 11 per cent of the outstations met the 'standard' criteria described above; that 80 per cent of the camps had 'substandard' facilities and only 9 per cent had 'superior' facilities. Therefore the regional picture reflects that the largest proportion of outstations have fewer facilities than the Aborigines would wish. Thus it seems predictable that in the long term the Aboriginal people will aim to rectify this imbalance and attempt to obtain underground water, adequate shelter, communications and transport at all camps. Government may well be advised to anticipate this and consider the planning and policy implications of such continued development.

$$
\text { Table } 8.4
$$

Level of facilities at camps recorded

Homel ands

Pintupi

Luritja

Walpiri

Pitjantjatjara/

Yangkunt $j a t j a r a$

Total
Substandard

Standard

Superior

Total
6

5

9

8

$28(808)$
-

3

1

-

4 (118)

\section{-}

$-$

2

1

3 (98)
6 
Housing

On a regional level there is some diversity in the type and number of houses allocated to different outstations. In the Luritja, Pintupi and Walpiri Homelands however, the Aborigines have all chosen and received the same kind of first stage houses. In the Pitjantjatjara/Yangkuntjatjara Homelands the Aborigines have sought more conventional brick houses and in the Pitjantjatjara/Ngaanyatjara region around Docker River the Aborigines have been provided with large, open hexagonal shaped shelters. These respective types of house are described in detail in the relevant chapter.

Table 8.5

Number of houses, radios and toyotas at camps recorded

Homelands

Houses

Radios

Toyotas

\begin{tabular}{lccc}
\hline Pintupi & 10 & 2 & 1 \\
Luritja & 32 & 4 & 5 \\
Walpiri & 36 & 4 & 7 \\
Pitjantjatjara/Ngaanyatjara & $15^{\star}$ & 13 & 11 \\
Pitjantjatjara/Yangkuntjatjara & $4 * \star$ & 1 & $0 * \star$ \\
Notes : $\begin{array}{l}* \text { hexagonal shelters } \\
\text { conventional houses } \\
\text { two tractors }\end{array}$ &
\end{tabular}

Discussing the merits of each of these houses it is apparent that first stage houses were popular with the Aborigines who had them. They provided basic shelter for people, protection for food and valuable belongings and privacy. The extent and way in which these houses were used by Aborigines varied from region to region. In the Pintupi Homelands people used the houses for storage and sheltered in them during the rainy season. They preferred to camp in the open behind windbreaks and larger bough shelters during the winter and made brush roofed sun shelters during the hot season. The Luritja used their houses more frequently; sometimes camping inside but more often camping underneath the verandah - and in some instances extending the verandahs into extra rooms. The walpiri use the houses most frequently sleeping inside as well as under the verandah. They, like other Western Desert groups, continue to use bough shelters and sun shelters during the day. The Aborigines gave us the impression that first stage houses were popular in these three homeland areas and we noticed that very few houses had been damaged or vandalized; a contrast to the settlements. Several Aborigines said they wished to have concrete floors put in their houses in order to help keep out mice, scorpions and snakes during the hot season and rain water during the wet season. This seems an entirely reasonable request and is probably a common feeling among the people with first stage houses.

With respect to the allocation of houses in the Luritja, Pintupi and Walpiri Homelands it appeared to us that the present number of houses was roughly proportional to the present core populations. This impression is based on the number of people we recorded at camps-(Table 8.1) adjusted 
with official figures and figures given to us by the Aborigines for camps which were in use but unoccupied during our visit (see regional profiles). It is possible that some of the official figures are exaggerated, thus inflating the population figures given. For example the official figures for Black Water and Ulumparru in the Luritja Homelands were 26 people at each camp - a figure which seems excessive given the transient nature of occupancy at those camps. Putting such possible discrepancies aside however we recorded 36 houses in the Walpiri Homelands for 206 people, (one house per six people); 32 houses in the Luritja Homelands for an adjusted population of 147-157 people (one house per four to five people); and 10 houses in the Pintupi Homelands for between $70-76$ people (one house for seven to eight people). Obviously there are less houses per head of population in the Pintupi region than in the other two regions. Naturally the ratio of houses to people is lower if the official figures for each region is used. These are substantially higher than our own, but given the adjustment for camps which were vacated at the time of our visit, we feel our figures accurately represent the population of these homeland areas at a given time.

Superficially, therefore, a case could be made for adequate housing having been provided to these three homeland areas. However, while partly true, this is not quite accurate for the situation on the ground. One of the most notable problems is that some of the larger outstations do not have enough houses while some smaller camps seem to have enough houses for themselves as well as itinerant visitors. For example, at Yumurrpa there were 16 people, but only two houses; at Emu Bore there were 20 people and only two houses, at Desert Bore there were five families (20-30 people) and only two houses; at Muyinnga there were 20 people yet only two houses; at Nyirrpi there were 120 people and five houses. This compares to Wakalpa where there were five houses for 12-15 people, Wayililinypa where there were six houses for only two people (although official record reveals between 15 and 28 official residents), and five houses at Yaripiilangu for only eight people. These apparent discrepancies reveal a need for accurate, up to date population figures and the logical allocation of houses accordingly. It seems senseless to have houses sitting unused at some camps, while neighbouring camps are overcrowded with little effective shelter.

In the Pitjantjatjara/Ngaanyatjara homelands the outstations have entirely different houses. Here large open hexagonal shaped roofs have been built at each camp. These cost about $\$ 16,000$ to establish (equivalent to four first stage houses) but appear to have only marginal value for the Aborigines. Their large size lends them more towards use by a small community rather than individual families; they do not provide any storage facilities and only give minimal shelter from stormy wet weather. Their main advantage is the shade they provide during the hot season. We are not convinced the Aborigines like the design and cannot help feeling that money would have been better spent constructing four first stage houses at each outstation instead of these. The Aborigines have not been stimulated to construct stone walls around the frames of each hexagon - as the design was intended to do and instead have built humpies underneath the hexagons or live in tin shacks and humpies outside. If we are honest we must state that we consider this type of housing to be a waste of money $(\$ 200,000$ so far) and question the wisdom of their continued construction. This is something that the government should consult the Aborigines about.

At the outstations around Ernabella the people had more sophisticated expectations for housing. They preferred small conventional brick houses costing between $\$ 25,000-\$ 30,000$ to the 'tin sheds' they perceived as being used in other homeland areas. In this region only four of the nine camps 
visited had 'houses' - with people at other camps living in tin sheds or brush shelter and humpies. Funds had apparently been released by the South Australian Government to provide additional houses at the remaining camps. We were under the impression that the Aborigines were generally satisfied with this and, as each outstation was more or less a family affair, single houses were enough for each camp. Visitors at camps seemed content to live in shelter provided by the owners of respective camps.

Throughout the whole region we perceived several other problems relating to Aboriginal housing which are worthy of discussion. One of the most obvious was the apparent lack of co-ordination between the construction of houses at camps and the location of an underground water supply. We are aware of the difficulties in finding water in the desert (see below) and the difficulties of co-ordinating this with the other aspect of camp development. However, without foresight and rational planning there are long term disadvatages to Aborigines and government departments alike. For example, in the Walpiri Homelands there were camps with houses but no water and camps with water but no houses. Because of this imbalance none of the camps were occupied; the people with the houses were not using the camp because there was no water and the people with the water were not living at the camps because there were no houses. It would thus seem more logical to provide water and houses together, systematically developing one outstation before tackling another rather than have everything half done. In this way the Aborigines can observe and foresee the development of individual camps and relevant government bodies can be rewarded by at least a little success for their efforts.

We also felt it was a mistake to set up camps before underground water supplies were located (such as at Puyurru, Pitakatal, Walka, Amputjuru, Tjupulu, Kunapula and many others). This short sightedness and impatience on behalf of both Aborigines and government bodies has meant some camps have had to be moved (Wayililinypa, Nyirrpi, Walka, Araluen), water has had to be reticulated over great distances from windmills (Alkipi, Ilpili, Tjukula, Warrapura) or transported manually from distant hand pumps (New Bore, Muntarti, Warampi, Ili Ili, Kutjuntari). Such frustrations hinders and destabilizes the movement and cause absolute despair to both Aborigines and government departments alike. We are convinced a little foresight, communication and patience on both sides could resolve some of these problems quite satisfactorily.

We also felt that there was not enough Aboriginal participation in the construction of houses and outstation development generally in the region. Teaching and helping Aborigines to build their own houses may be more expensive for Departments and tiresome for builders who seek to finish building contracts quickly and profitably but in the long term it is likely to be of more benefit to the Aborigines. This not only provides a means of employment, but is necessary if the Aborigines really wish to achieve some independence and self determination. At the moment it appears there is almost no Aboriginal involvement in any of the construction activities in the Pintupi, Luritja or Pitjantjatjara/Ngaanyatjara Homelands. In the Walpiri Homelands some Aborigines help in the drilling programs, road grading and fencing projects and in the Pitjantjatjara/Yankuntjatjara region the Aborigines are actively involved in the development of their outstations.

Finally we should add that the housing situation we observed was certainly different from that described by Nathan and Djabanangka in the Western Desert in 1983. Then 'none of the people' at any of the outstations 
they visited (and which were subsequently visited by us) had any permanent housing and camps around Docker River were the worst off (1983:145). Thus, over the last year the housing problem on Aboriginal outstations has met with some degrees of success. Nevertheless humpies and windbreaks are still common in the region (we counted 131 at the camps we visited). There are several reasons for this. In the Pintupi Homelands for example, the people still have a traditional penchant for more traditional style houses although at some camps (Desert Bore, Muyinnga) there are simply not enough houses to go around. This is also the case at some of the walpiri and Luritja Camps (Warrampi, Nyirrpi, Yumurrpa, Emu Bore). In the Pitjantjatjara/Ngaanyatjara region there are many traditional and semi traditional shelters because the contemporary houses provided do not meet the needs of the people. In the Pitjantjatjara/Yangkuntjatjara region people are living in humpies where houses are not yet provided (Eagle Bore; Tjatja) but at other camps they are used by weekend visitors and other transient visitors. Obviously it would be impractical to expect the government to cater effectively for the never ending flux of people at outstations and in the Pitjantjatjara/Yangkuntjatjara Homelands the Aborigines have largely taken over this responsibility themselves. In other areas the Aborigines make do with what they can. At Mt. Liebig for example there are not enough homes because a relatively large number of people have moved there from Ilpili and Warren Creek following deaths. At Warampi the camps regularly doubles in size with visiting relations from Mt. Allen. In these situations we believe all the government can be expected to do is cater for the core population of each outstation.

\section{Water}

Water has always been of paramount importance to Aborigines living in the desert region of Australia. Unlike other arid regions in the world which are dissected by permanent river systems - there are no permanent rivers at all in the Central and Western Deserts. In fact in the Western Desert there are not even any rivers - simply short, ephemeral creeks. Rainfall was thus of prime importance. Its fall determined the distribution and availability of plant and animal food and its abundance determined the size and extent of the seasonal subsistence round and ceremonial gatherings. Traditionally, if rainfall was great people travelled great distances to fertile areas to attend large ceremonial gatherings. Conversely, in times of drought small groups of people were isolated from each other by massive expanses of waterless country, on foraging 'islands' around reliable waterholes. In the old days the high evaporation of surface water rate forced people across the landscape sequentially from the most ephemeral to the most reliable waterholes. Firstly swamps dried up, then claypans, small rockholes and soaks until by the end of the dry season only the largest, best shaded rockholes in the hills and rare springs were left (such as Ilpili, Kutjuntari, Tjukula and Putarti Spring) (see Gould 1969; Peterson 1978; Cane 1984). Water was of critical economic importance and was the weakest link in the desert subsistence strategy. In the Western Desert for example, the countryside was sufficiently fertile to support much greater populations than actually existed. Latz (pers. comm.) estimates there are enough Acacia seeds alone to support a population of 2 million people but water shortages prevented this from occurring. The regional population density was probably in the order of about one person per $150 \mathrm{sq} \mathrm{km}$ (Long 1971; Cane 1984) and the total population was about 7,000 people. The population density was probably higher in the central ranges where springs and large rockholes were more common among the mountains and there were deep permanent gorges along large rivers (Finke, Ellery River). 
Water continues to be just as important today to Aborigines living in the desert and without it sedentary settlement of the desert region is still impossible. Hence the Aborigines stress that water is the number one thing' and constantly emphasise the need to get handpumps and windmills. Water, however, is hard to find - some camps have had up to 5 - 7 bores sunk with no result (Pitakaltal, Puyurru, Walka). Nevertheless 77 per cent (42) of the camps we visited have been supplied with underground water so far and of these about half (25 camps - 47 per cent) have been equipped with windmills. Another 16 camps have been equipped with hand pumps ( 30 per cent), five bores have yet to be equipped and six camps (12.5 per cent) are still relying on carted water or traditional waterholes for survival (Table 8.6).

Table 8.6

Water facilities at all camps visited

Homelands

Windmill Hand only Bore only Drums Total

Pintupi
Luritja
Walpiri
Pitjantjatjara/
Ngaanyatjara
Pitjantjatjara/
Yangkuntjatjara

Total

\begin{tabular}{rlllr}
\hline 6 & 5 & 1 & $\star$ & 6 \\
7 & 5 & $1^{\star \star}$ & - & 12 \\
5 & 1 & 2 & 3 & 13 \\
7 & 5 & - & 3 & 13 \\
\hline $25(478)$ & $16(308)$ & $6(12.58)$ & $6(12.58)$ & 53
\end{tabular}

Notes: $\star 2$ camps still using drums

* equipped with diesel pump
** under repair

We should also note however that there were additional camps we did not visit which had no water. These camps were not visited because they were unoccupied and in most cases the reasons they were unoccupied was because they had no water. DCD informed us that they will not drill for water until an outstation has been recognized by DAA. Yet DAA usually does not recognise an outstation until the group have demonstrated some stability and commitment to their site. We can understand the rationale for this stance, but should underline that it is virtually impossible to live permanently at a camp in the Western Desert and thus demonstrate the necessary degree of commitment without permanent water. This catch 22 situation must be frustrating for both government and Aborigines alike. The only solution we see is to consult regularly with Aborigines and anthropologists who have extensive local knowledge of relevant areas and to employ government field officers to conduct extended (about one month) annual field trips. Our observations suggested that field officers only spend a short time in the field and thus never become well known to the Aborigines and never really 'get to know the people' themselves. It is only through long term contact and familiarity with a community that field officers can get to know the 'genuine' Aborigines from the 'users', get to know which spots are likely to be permanent locations for outstations, and can explain the slow complicated departmental processes which must be gone 
through before facilities can be obtained. In some cases it appeared that government officers are perceived as little more than a source of funds to be milked and in some instances are thought of as nothing more than 'that pukin bastard' who flys in, flys out and never seems to deliver the goods.

\section{Equipment}

Another area worthy of comment was the Aborigines' universal desire to obtain windmills in preference to hand pumps. There are arguments for and against both types of equipment. The Aborigines complain that hand pumps are hard work - a real problem for pensioners aggravated when hand pumps are a long way from camps (Ili Ili, New Bore, Warampi Kutjuntari). Of more significance, they complain hand pumps do not supply enough water to maintain good health among large groups of people and they are inadequate if anybody wants to establish a garden. On the positive side though, hand pumps are relatively inexpensive thus more people can be provided with them from a given budget allocation. They also are virtually maintenance free and easy to repair (Walker 1982) - a significant advantage given Aboriginal claims for independence from European interference and administration. They are also more reliable, less likely to break down and provide water when there is no wind. Windmills however, are much more convenient. If equipped with an elevated tank and effective reticulation, water can be obtained in camp at the turn of a tap. However they are more likely to break down (Ilpili, Five Mile, Kungakyunti) and there are few Europeans at communities with the skills or time to repair them (the outstation adviser at Ernabella spends virtually all his time repairing and servicing windmills but does not have time to do any thing else) and the Aborigines do not have the skills to do this. Furthermore reticulation is often exposed, or laid very close to the surface in black (rather than white) PVC pipes and thus provides very hot water during the summer. Pipes are also left exposed rendering them vunerable to fire, vandalism and crushing by vehicles (Itjinpiri, Tjukula, Warren Creek, Alkipi, Ilpili). Taps invariably leak (creating pools of unhygenic stagnant water and potential snake traps). calcify and become blocked (Mt. Liebig, Five mile). Windmills are also vunerable to wind droughts - thus requiring diesel pumps or extra large reserve tanks. Also there is no guarantee that effective reticulation will be provided. At Ernabella the Aborigines lay their own reticulation (with some European help) and is thus quite extensive (Eagle Bore has 11 taps for 20 people). In other areas, where the Aborigines rely on Europeans to lay reticulation it is often not satisfactory (Mt. Liebig - 1 leaking tap $200 \mathrm{~m}$ from a camp for 60 people).

Overall we feel (and we should note these feelings are not shared by all Aborigines) that hand pumps are superior to windmills and their associated reticulation for many situations. This is because they are simple, cheap and reliable (see Walker 1982). Their major draw back is they are often located a long way from camps and are not ideally suited to gardening. We do not consider the last point to be particularly significant at the moment given the Aborigines' limited involvement in horticulture (see below), but the former point must be tackled. We consider it is essential to locate a water source before a camp is established. Presently camps are set up and then everyone hopes they find water nearby. This is clearly impractical - as water is often not found locally and camps have to be moved (Araluen, Walka, Puyurru, Djulpungu), or extensive reticulation has to be laid back to camp (Tjukula, Ilpili), or people have to walk a long way (half a kilometre) to a hand pump (New Bore, Muntarti, Warampi, Kutjuntai, Kunapula). Patience on behalf of the Aborigines and extra interdepartmental co-operation and detailed field.research is essential to speed 
up the process of finding water and organizing drilling programs at intended outstations before they are equipped. At some camps the Aborigines have been waiting years - at some camps ( $T$ julpungu) almost 10 years to get water at their camps. We are aware of the difficulty in providing water at remote locations and the need to have the quality of water tested before bores are equipped but it is hard to believe that such processes take years to come to fruition. The Aborigines certainly believe delays are unnecessarily long. These delays (along with other broken promises and the gaps between being provided materials and having it installed) sap the enthusiasm of the Aborigines and destabilize camps before they really get the chance to begin.

Water Quality

One of the greatest problems faced by Aborigines and Government Departments is the task of finding water fit to drink. In the course of this study we gathered water quality data for 32 camps and found 31 of these have water which is marginal to very poor in quality. Specifically there were 21 camps with water above the acceptable levels of fluoride (Hart 1974, Department of Health 1980). At these camps the fluoride content varied between $1.5 \mathrm{mg} / 1$ at Desert Bore to $2.6 \mathrm{mg} / 1$ at David Well. Twenty four camps had water with levels of nitrate higher than acceptable standards $(10 \mathrm{mg} / 1:$ ibid). At these camps the level varied from $10 \mathrm{mg} / 1$ at Black Water to $146 \mathrm{mg} / 1$ at Tjinki. Three camps had water with a high iron content and seven camps had water with unacceptable levels of dissolved solids.

Excessive amounts of iron makes water tea coloured, rust tasting and raises the possibility of bacterial contamination. Too many dissolved solids make the water so awful it is undrinkable. High levels of fluoride cause mottling on teeth. This only occurs during the growing stage of teeth (up to the age of $n$ ine) and is not a problem for adults. Low levels of fluoride $(1 \mathrm{mg} / 1)$ are in fact advantageous - lowering the incidence of tooth decay, whereas large quantities $(8-20 \mathrm{mg} / \mathrm{l})$ can retard bone growth and cause reabsorption of the bone. Death can occur if $2.5-4.0 \mathrm{~g}$ of fluoride are consumed in a single dose (Hart 1974). The highest level of fluoride at any outstation was $2.6 \mathrm{mg} / 1$ at David Well. This is unlikely to result in anything more than mottled teeth.

High nitrate levels are more dangerous. Nitrate, when obtained from food or water, is absorbed by the blood, reducing the oxygen carrying capacity of the blood (metahaemoglobinaemia). There is experimental evidence conducted on pregnant rats that this can lead to irreversible brain damage in offspring. Infants are also susceptible to metahaemoglobinaemia as their fluid intake is three times that of an adult per body weight and an infant's digestive track is not sufficiently developed to reduce the level of nitrate absorbed. High levels of metahaemoglobinaemia are also found in babies with respiratory illness or diarrhoea. The last three factors are of significance to Aboriginal people. Research among Pitjantjatjara and Pintupi people revealed they drank and turned over twice as much water as Europeans (MacFarlane 1978) - thus possibly rendering them vulnerable to higher levels of nitrate intake. Respiratory problems and diarrhoea are standard problems for children on Aboriginal communities. There is evidence that high vitamin $C$ intake inhibits susceptibility to the disease - an important factor given the frequent consumption of vitamin C rich bush tomatoes by Aborigines in the desert. Surface water does not contain high levels of nitrate unless heavily polluted with bacteria (e.g. from animal excrement). 
Since 1945 when metahaemoglobinaemia was discovered there have been over 2000 cases, including many fatal poisonings of infants, resulting from the ingestion of water containing high levels of nitrate (Hart 1974:211). The disease has also been reported in infants drinking water with less than $10 \mathrm{mg} / \mathrm{l}$ of nitrate. Hart (1974) and the Department of Health (1980) considers $10 \mathrm{mg} / 1$ of nitrate to be the maximum desirable level of nitrate consumed by people. In South Australia two bores near Mt. Gambier were taken out of action because their nitrate levels were recorded up to 26.2 and $23.6 \mathrm{mg} / 1$. Sixteen bores at Aboriginal camps have higher levels of nitrate than these. There are suggestions that levels of up to $45 \mathrm{mg} / \mathrm{l}$ of nitrate are acceptable (Camp et al. 1978; Walker 1982) in drinking water and in Europeans levels are allowed up to $100 \mathrm{mg} / 1$ (WHO 1981), with the proviso that physicians are advised of the possibility of metahaemoglobinaemia occurring in infants. So far no cases of metahaemoglobinaemia have been recorded in Aboriginal outstations - but this does not mean they do not exist. We would think that close medical attention should be paid to camps if they are to use water with levels of nitrate higher than $45 \mathrm{mg} / 1$ but suspect this would be hard to monitor. Presently 10 of the 32 camps we have data for contain more than $45 \mathrm{mg} / 1$ of nitrate and three camps contain levels higher than $100 \mathrm{mg} / 1$ (see figures in each chapter and Table 8.7).

Table 8.7

Number of camps with excessive levels of nitrate,

Eluoride and other contaminants (data only available for 32 camps)

Homelands

Fluoride Nitrate other

Camps Camps with

tested poor water

\begin{tabular}{llllll}
\hline Pintupi & 2 & 2 & 3 & 5 & 5 \\
Luritja & 6 & 8 & 1 & 10 & 10 \\
Walpiri & 4 & 7 & 3 & 8 & 8 \\
Pitjantjatjara/Ngaanyatjara & 5 & 3 & 1 & 6 & 5 \\
Pitjantjatjara/Yangkuntjatjara & 4 & 3 & - & 5 & $5 *$
\end{tabular}

Note: * We believe three other camps, Itjinpiri,

Black Hill and Araluen have drinkable water.

Because of the dangers inherent in the water at many camps it is fortunate that the Aborigines have retained many basic traditional patterns of behaviour. Babies are usually breast rather than bottle fed until they are two to three years old thus giving themselves time to get over the danger period for nitrate contamination. Also the people are still nomadic - and thus regularly remove themselves from any source of contaminated water.

A satisfactory solution to the problem is difficult to foresee. Even if new bores are drilled at the worst camps there is no guarantee that better water will be found. Currently the responsibility for drinking the water rests with the Aborigines. They are asked to provide written acceptance of the water provided if its quality is doubtful. This seems unsatisfactory as we believe the Aborigines, generally, are likely to sign such a statement to get their bores equipped. and we are not convinced that 
the advice they are given is always satisfactory or that they are always aware of the long term implications of their action.

There are some technical alternatives for improving the quality of water at camps. These include various methods of bacterial, chemical and physical treatment - but all are expensive, technical, and not ideally suited to the outstation environment. The best alternative is probably solar distillation of a sufficient quantity of water for young infants, bottle fed babies and pregnant mothers to drink. The trouble with this technique is that it is expensive and the large glass panels needed for evaporating the water are likely to be broken (see also Camp et al. 1978; Walker 1982). Large artificial dams capturing runoff are also a viable option but these run the risk of being swum in and polluted - thus becoming a source of severe gastric infection. Bacterial pollution of surface water is also a source of nitrate contamination.

We think another more viable option may be to re-open and provide access to major traditional soaks and waterholes. This idea is developed further in the following section on traditional land use, but briefly would require grading a series of simple tracks connecting important rockholes and soaks and passing through important hunting and foraging areas. This is likely to encourage Aboriginal groups to travel away from camps and underground water supplies quite regularly and live and hunt at these (nitrate free) surface waters for periods of time. Such trips would reduce the risk of chronic nitrate contamination.

\section{Communication}

Toyotas: (Table 8.5)

Toyotas are probably one of the most keenly sought after commodities among outstation occupants. Among the camps we visited all but two of the camps near Docker River had ABTA vehicles. Ten of the 13 camps near Yuendumu visited had vehicles, five of the 12 camps had vehicles near Papunya and only one of the six camps visited near kintore had a community toyota. None of the Ernabella outstations had community vehicles - they shared two community tractors.

Cynics have expressed the view that 'toyota dreaming' is the fundamental motive for the development of many outstations. Our experiences of the outstation movement do not support this. We tend to believe the ideological motivation expressed by most Aborigines for the outstation movement in this area, realising at the same time though, the importance of toyotas - particularly once a camp has been established. This was demonstrated at a large Aboriginal Meeting at Amoongana in 1984. The issue, to be discussed at this meeting included water, housing, toyotas, radios and glue sniffing, yet the preoccupation of the Aboriginal leaders was water (not toyotas) and the entire two day meeting centred around this. Furthermore we were never pressured by Aborigines to help obtain vehicles although frustration and anger was common over the lack of water and the lag time between bores being drilled and equipped. Also less than half (45 per cent) the camps visited had ABTA toyotas. If vehicles were the principle motive behind outstation development we would expect the percentage of toyotas to be higher and one would expect complaints about the lack of toyotas to be very vocal.

Toyotas are, however, important to Aborigines once camps have been set up. At camps which are remote it is essential to have efficient, reliable 
transportation. As indicated throughout this study, the Aborigines travel extensively for social, religious and sporting reasons. When children or elderly people are in camp, the Aborigines like to have the security of at least one vehicle in camp for their sake.

However, while toyotas are an integral part of any outstation, their availability also has disadvantages. On the positive side they help improve the nutritional status of people by extending their hunting and gathering range. Socially they are also desirable - as they allow visits to friends and relatives who live a long way away. They also play a dynamic role in transporting people to and from ceremonies. In fact it is fair to say that the strength of contemporary ceremonial 1 ife in the Central and Western Deserts rides very much on the toyotas back. Without toyotas much of the 'business' activities would be severely curtailed. Thus toyotas play an indispensable role in maintaining the cultural well being of outstation people.

On the negative side toyotas temporarily destabilize outstations, are an easy means for obtaining grog and are often physically abused. With regard to the first point it is more accurate to say that toyotas increase the mobility of people than decrease the stability of their camps. Such high mobility is acceptable to Aboriginal people but frustrating for community staff and government officers. We cannot quote any camp (without reservation) and were told of no camp which has been completely destabilised by the arrival of a toyota. Tjulpungu may be close to fitting the bill but as this camp has been frustrated by lack of water for the last eight years one cannot blame the people for being unsettled. In areas such as Docker River where there is evidence for instability this does not seem attributable to the availability of toyotas alone.

Toyotas make it much easier for people to obtain grog. Toyotas have been confiscated at Yuendumu for grog running and alcohol related incidents have destabilised camps in the Luritja Homelands. Several things may be done about this. One is to enforce 'sit down' legislation preventing the removal of alcohol from outlets. Another is to substitute toyotas by tractors, but this has obvious disadvantages and has been unsuccessful in the past. Ultimately we consider the question to be an Aboriginal problem and one which they are aware of. The Aborigines are attempting to distance themselves from alcohol and the homelands movement itself is part of their solution. Problems with alcohol may well diminish as the homeland movement exerts greater control over peoples' lives but no doubt some people will continue to go on binges and young men will continue to orink and return grog to camps.

A third problem associated with toyotas is that they tend to be wrecked quickly by Aborigines. This is partly because of their scarcity and related over-use by many people, but also because they are often driven without adequate servicing. These factors, combined with bad roads, wear even the toughest vehicles down quickly and numerous wrecks of old toyotas are found at the older camps (Nyirrpi, Kungakunti). This situation is also aggravated by the general absence of spare parts and/or people with the mechanical skills to fix them. This could be partially rectified if young Aborigines were given some basic mechanical training.

One last comment needs to be made regarding the importance of the ABTA funding for Aboriginal toyotas. ABTA funds are provided by Aboriginal royalties and administered by DAA. If Aborigines can provide 10 per cent of the purchase price of a vehicle then ABTA makes up the rest. Apart from the 
obvious advantages of obtaining cheap toyotas we consider this scheme has an important educational value to Aborigines. It provides the Aborigines with an achievable monetary goal and thus teaches them something of the value and meaning of money. In our experience the Aborigines take the saving process very seriously and consequently get practical experience with and learn about money in the process. At different times we have observed a constant stream of people coming through community offices checking, withdrawing, and contributing to their savings. In some instances people returned several times a day with a different family member to gloat over their money and work out how much there was to go. The educational value of this scheme is therefore invaluable if Aboriginal people are to remove themselves from their depedency on community advisers and eventually to hand out and organize their own money.

\section{Radio Phones ('radios'): (Table 8.5)}

Thirty two of the 53 camps visited had been supplied with radios. All of the camps in the Pitjantjatjara/Ngaanyatjara Homelands had been supplied with radios, nine of the 12 camps in the Luritja Homelands had been given radios and seven of the 13 camps in the Walpiri Homelands had been given radios. Again the Pintupi and Pitjantjatjara/Yangkuntjatjara camps were the worst equipped - with one radio between nine camps around Ernabella and two radios between six camps near kintore.

Radios are important to Aboriginal people as they are to all people in remote areas. They are a necessity in times of sickness and emergencies and are highly valued for general communication - such as organizing meetings with government officials, arranging community and ceremonial business. Naturally the relative importance of and need for a radio varies according to the proximity of camps to larger communities. Thus camps such as those around Ernabella are probably less in need of two-way radios than remote camps from Kintore, Docker River and Yuendumu. Ideally however each camp should be equipped with an efficient means of communication. Who can predict when a child may break a leg, cut a vein with broken glass, be bitten by a snake or a spider? Anyone who has worked in Aboriginal communities is aware of the chronic weaknesses in effective communication at times when there is a need to organise meetings with the Aborigines, communicate news, locate certain people and request permission to visit groups and communities. Thus apart from the dangers of sickness and various emergencies there is a need for an effective communication network for the benefit of both Aborigines and Europeans alike. Such a network would be made more effective by providing different language groups with different frequencies - or alternatively by separating the 'chatter' from 'business' frequencies.

An additional problem is an obvious need to keep radios at the camps to which they have been allocated and to keep the radios in working order. This is done most effectively at outstations near Docker River, where radios are fixed to houses, well sheltered, have automatic on/off buttons, are powered by solar charged 12 volt batteries and have fixed aerials. All 13 radios in this region were in working order, but this was not the case in other areas. In the Luritja Homelands for example five of the nine radios allocated had been borrowed and never returned and two of the remaining four were broken down - having been left exposed to the rain during the wet season. 'In' order to keep radios operational they must be made automatic, solar powered and immobilized. 
Services: (Table 8.8)

This discussion relates to the provision of essential services (health, education, stores) to the camps which were in use at the time of our visit. The outstations in the Pitjantjatjara/Yangkuntjatjara Homelands and five camps in the Luritja Homelands are not discussed; these camps appeared abandoned and thus were not supplied with essential services during our visit. Among the remaining camps we classified the services allocated to 28 ( 80 per cent) as 'standard' and generally believed this to be an adequate level of servicing. This contrasts with the judgement of Nathan and Japanangka (1983:147-49) who considered the service allocation at all camps in the regions we visited to be inadequate. This is largely because of our differing perception of what constitutes adequate servicing at camps. It was our view that a camp with standard - or adequate - level of services should receive regular weekly visits by a health sister or be within two hours access of a health clinic; be within two hours of a store and one hour of school. It was our impression that this level of servicing was also seen as satisfactory (although maybe not perfect) by the Aborigines. We feel this is reasonable given financial and staffing difficulties in remote areas and meets the needs of most people at outstations and thus should be standard at most outstations. This level of service approximates that of other people in remote stations and towns and is not unreasonably inferior to that obtained in city centres. Even in cities one has to make appointments to see a doctor at least a day in advance - and in casualty wards one may have to wait for hours before being attended by anyone. We have invariably found health care on Aboriginal communites quick and efficient and nurses and doctors to have an excellent local knowledge and expertise in a wide range of areas.

Table 8.8

Level of services. at camps recorded

Homelands Substandard Standard Superior Total

\begin{tabular}{lcccc}
\hline Pintupi & 1 & 4 & - & 5 \\
Luritja & - & 8 & - & 8 \\
Walpiri & 6 & 7 & - & 13 \\
Pitjantjatjara/Yangkuntjatjara & - & 9 & - & 9 \\
\cline { 2 - 5 } & Totai & 7 & 28 & 0
\end{tabular}

In contrast Nathan and Japanangka (1983:147) claim that 'health provisions at all camps are inadequate', claiming that:

As a minimum each camp should have two resident healthworkers to attend the male and female populations respectively, a small caravan to store medical supplies and to serve as a clinic, a radio and a vehicle and regular visits from sisters and doctors (1983:148). 
They also felt 'all camps require the basic educational facilities of qualified teachers and Aboriginal assistants' (ibid.) and that:

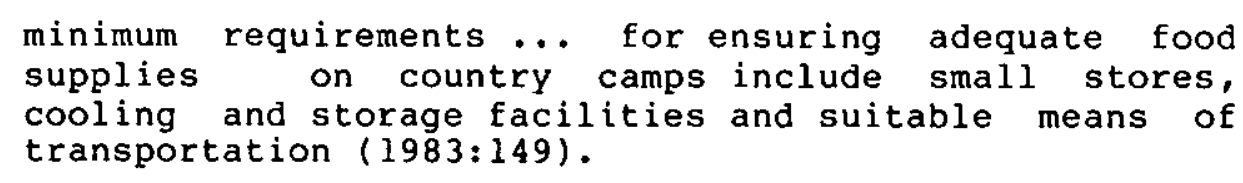

We consider this level of servicing is impractical and doubt if every outstation wants to become a mini-community, or would welcome the imposition of such infrastructure and the Europeans that would go with it. Such recommendations ignore the fact that traditional Aboriginal medicine men still play an active role in Aboriginal health care and should continue to do so. Aboriginal traditions are also learnt by children on outstations and the bush larder is still an important source of food to Aboriginal people. This cannot be effectively replaced by a ready supply of sugar, flour, condensed milk and soft drink from a store.

Table 8.9

Relative importance of bush foods at camps recorded

Homelands

$\begin{array}{ccc}\text { Major } & \text { Moderate } & \text { Minor } \\ (508) & (20-308) & (10-158)\end{array}$

Total

\begin{tabular}{lcccc}
\hline Pintupi & 1 & 4 & 1 & 6 \\
Luritja & - & 4 & 4 & 8 \\
Walpiri & 1 & 6 & 2 & 9 \\
Pitjantjatjara/Yangkuntjatjara & - & - & 9 & 9 \\
\cline { 2 - 5 } Total & 2 & 14 & 16 & 32
\end{tabular}

If we examine each of the particular areas of servicing in detail there are some obvious inadequecies. One of the most obvious is the difficulty of providing reasonable European education (particularly basic reading and writing skills) to Aboriginal children. In Figure 8.2 it is apparent that most of the outstations are relatively close to large communities and thus it is practical for children to commute regularly to schools. This is not the case for more distant camps where children must be either left at the main community or attend part-time schools at the larger outstations (e.g. Mt. Liebig). This is unsatisfactory as it separates children from parents, children get into trouble, camps are destabilised and the part-time schools are under-equipped. Some children (particularly in the pintupi region) simply do not go to school at all. There seem to be two solutions to this; either improve the existing education facilities at larger outstations and increase the number of part time schools at other large, central camps (e.g. Nyirrpi) or, preferably use two way radios to take education to each camp. We have not investigated this possibility but believe that with the co-operation of DAA, DCD, Education Departments, School of the Air and CAAMA a daily 2-3 hour education service could be provided over the radio for Aboriginal chldren with satisfactory results and relative ease. 


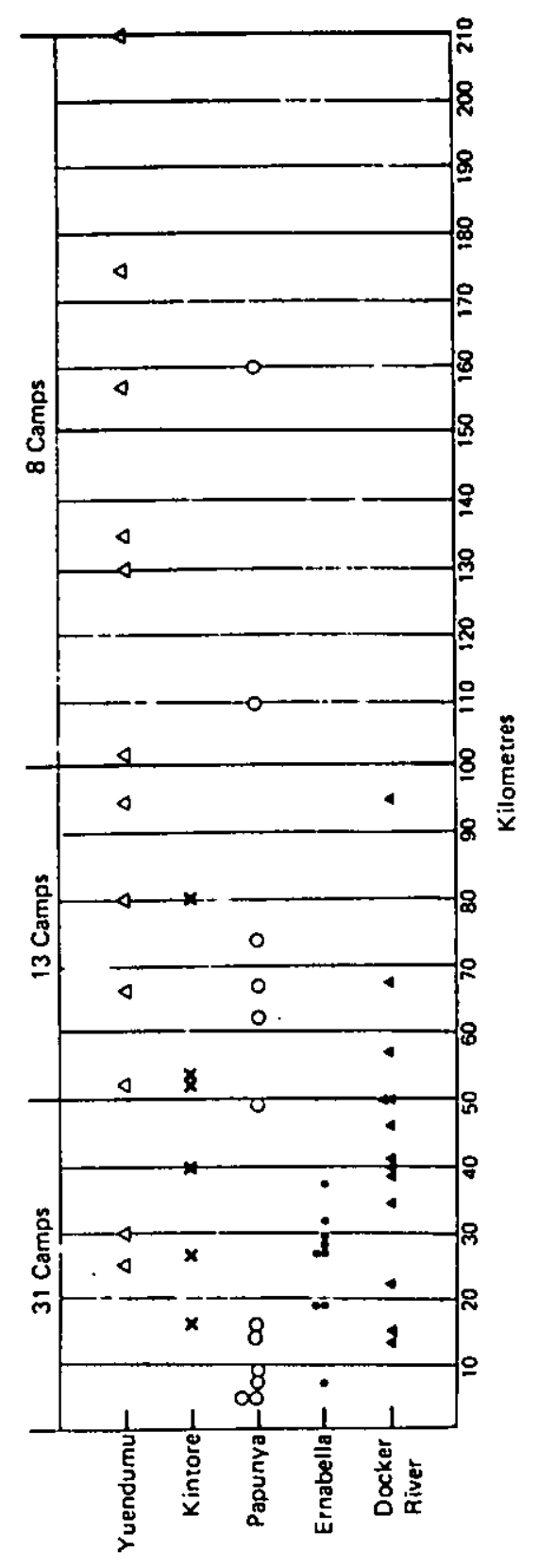


With respect to health services we felt these were generally satisfactory. Again, most camps are close to major communities and access to health care is relatively easy. Furthermore 45 per cent of the camps visited had toyotas (see above) and Young (1982:75) records 62 per cent of Central Australian outstations have private vehicles. There are also Aboriginal medicine men living on outstations and these are very effective with a wide range of medical disorders. It would also be beneficial to provide each camp with a medical chest (as is done around Ernabella) and provide selected people with basic St. John Ambulance first aid training. Naturally there are health risks and dangers living on remote outstations but we believe that the Aborigines generally recognise and accept these risks. Overall we found health staff experienced and comitted to the welfare of outstation communities. Sisters made regular visits to all camps we visited which were in regular use, although as far as we could ascertain some of the camps north of Yuendumu did not receive regular visits and this should and could be rectified.

The provision of store food is also reasonable. Once again the camps close to communities have no trouble getting store food and buy great quantities of food on pay days (Young 1984). Things are not quite as easy at more distant camps but some of these use bush foods quite extensively and get food from small resource centres such as Kintore, Nyirrpi and Mt. Liebig.

As outstations are established further and further away from the main communities the provision of services is, predictably, going to become more and more difficult. The only solution to this is to establish resource and service nodes at outstations strategically located within that development. Such examples are already in existence at Nyirrpi, Kintore and Mt. Liebig and are planned for Walawala (Kiwikurra) west of Kintore. One can predict that as the homeland movement progresses these nodes will become more numerous and distant and may well require a co-ordinated resource supply bringing food, pension cheques medical facilities, mechanical goods, banking facilities - by air or road. We would envisage that such service centres will contain small stores - selling basic items such as meat, tea, sugar, flour, chips, fruit juice, durable vegetables; a basic health clinic with at least one trained Aboriginal health worker, receiving regular weekly visits from a doctor and a small school, reasonably equipped and staffed on a regular part time basis with access to a School of the Air service designed for Aboriginal children.

Apart from the obvious advantages of such service centres we also observed that they act (if Nyirrpi, Kintore and Mt. Liebig are any example) as important keystones in the oustation movement. They provide essential resources and services and thus attract more people. This reduces the mobility of people and increases the social and cultural interaction of people at a local level. Families are not split up and there is not the same necessity for young adults to.go to find 'action' in the larger communities. People do not have to travel great distances to fulfill basic social, family and ceremonial obligations or to get food, go to school or visit children. Consequently these camps and their surrounding camps are usually more stable and the people more satisfied. There is an air of purpose about them, and most importantly there are more children at camps living the 'proper way'. 
$\underline{\text { Land Use }}$

Match Stick Farming

The food gathering life is parasitical; the Aborigines are absolutely dependent on what nature produces without any practical assistance on their part (A. Elkin $1943: 14)$.

Europeans, upon their arrival in Australia perceived a country they considered unused and a race of people who had done nothing with the land. This view, as contemporary research indicates, was erroneous and fire as a tool has probably been used by Aboriginal people since they first arrived in Australia to control resource location, diversity and intensity. Evidence for a florescence of bush fires is recorded approximately 100,000 years ago (Singh et al. 1981) and suggests that this was man's first attempt to manage the Australian environment. This time is 60,000 years before any tangible dates for the presence of man in Australia but is nevertheless within the realm of realistic archaeological speculation for man's arrival in Australia (Flood 1983). Since that time there is continuing paleoenvironmental evidence of fire in the Australian landscape and an associated decline in the original vegetation; sheoaks (Casuarina spp.), pines (Callitris sp.) and various rain forest species, in favour of fire tolerant plants such as gum trees (Eucalyptus) and wattles (Acacia spp.) (Sing et al. 1981; Kershaw 1981; Latz 1981). These species are generally considered characteristically Australian but their abundance is probably a direct legacy of Aboriginal land management practices. Fire has thus had a dramatic impact on the Australian landscape. Aboriginal man used it to alter the structure of vegetation and opening regions of forest for hunting and gathering (Jones 1969); his fires have been responsible for increased rates of sedimentation (Hughes and Sullivan 1981) and may have played a major role in the extinction of giant marsupials which originally roamed the Australian continent (Jones 1968, 1975).

Jones (1969) described this pre-contact burning practice as ifire stick farming'. He records extensive use of fire by Aborigines in Tasmania to manage their environment and the same has been recorded in south east Australia (Mitchell 1847; Flood 1983), South Australia (Giles 1889); Central Australia (Latz 1981), Western Australia (Kimber 1983, Hallam 1975, Gould 1971) and Queensland (Kershaw 1981, Beaton 1982). The practice of 'fire stick farming' thus appears to have been universal in Australia and, as we will outline, fundamental to the hunting and gathering way of life of the Aborigines. It was an integral part of the traditional Aboriginal subsistence strategy in the past and, although firesticks have been exchanged for matchsticks today, burning continues to be important practice in many traditional parts of Australia (Plate 8.1 ).

The reasons why Aborigines burn are various. Major Mitchell perceived the essence of the importance of fire in 1848:

Fire, grass, kangaroos, and human inhabitants, seem all dependent on each other for existence in Australia; for any one of these being wanting, the others could not longer continue. Fire is necessary to burn the grass, and from those open forests, in which we find the large 
forest-kangaroo: the native applies that $f$ ire to the grass at certain seasons, in order that a young green crop may subsequently spring up, and so attract and enable him to kill or take the kangaroo with nets. In summer, the burning of long grass also discloses vermin, birds' nests etc., on which the females and children, who chiefly burn the grass, feed. But for this simple process, the Australian woods had probably contained as thick a jungle as those of New Zealand or America, instead of the open forest in which the white men now find grass for their cattle, to the exclusion of the kangaroo, which is well-known to forsake all those parts of the colony where cattle run. The intrusion therefore of cattle is by itself sufficient to produce the extirpation of the native race, by limiting their means of existence; and this must work such extensive changes in Australia as never entered into contemplation of the local authorities (Mitchell in Mulvaney 1975:242).

Jones (1969) in his original essay recorded six reasons (apart from domestic purposes) for which the Aborigines used fire. These were for fun, to signal one's presence, to clear the ground for travelling, to extend man's habitat, to hunt animals and attract animals and most importantly, to regenerate plant food.

With respect to hunting, Aborigines used fire for the same reason as modern pastoralists burn country today (Beard 1981; Burbige 1943); to clear away old woody plants and stimulate the growth of fresh, edible and nutritious grasses and shoots. By using fire the Aborigines thus attracted large herds of kangaroo to known areas and effectively localised them for the period of regeneration. When kanagroos were abundant the men used to hunt them at will, even maiming some, keeping them alive until wanted (Terry 1974:135). Fire was also used to flush animals out (Gould (1980) records $23 \mathrm{sq} \mathrm{km}$ burnt in the process of catching three feral cats) and to drive animals into ambush or over cliffs (Latz 1981).

The use of fire was probably most effective in regenerating plant foods and traditionally desert Aborigines burnt their country every spring to ensure productive gathering the following year (Cane 1984; Kimber 1983). Fire, for example greatly increases the availability of many edible grass seeds. Burbige (1943:155) records that following fire in the Great Sandy Desert spinifex plains were completely replaced with Eragrostis eriopoda, a very important seed food traditionally. We have recorded precisely the same thing (Cane 1984). Fruits respond equally dramatically to fire and for example, O'Connell et al. $(1981: 28)$ recorded an 80 -fold increase in the production of solanum fruits following fire. In another example, Latz (1981) records that following burning a colony of $\mathrm{s}$. centrale yielded 40150 fruits per plant, weighing $2.70 \mathrm{~g}$ each. This compared to only about 20 fruits per plant weighing only $1.39 \mathrm{~g}$ each, at the same colony after a period of three years without fire. Cane (1984) recorded an equally phenomenal increase in the yields of Ipomoea tubers following fire. In the first year a colony of Ipomoea plantswere almost completely bereft of tubers - but the next year, following fire, people gathered new tubers at the same place at a rate of $2-4 \mathrm{~kg}$ an hour. 


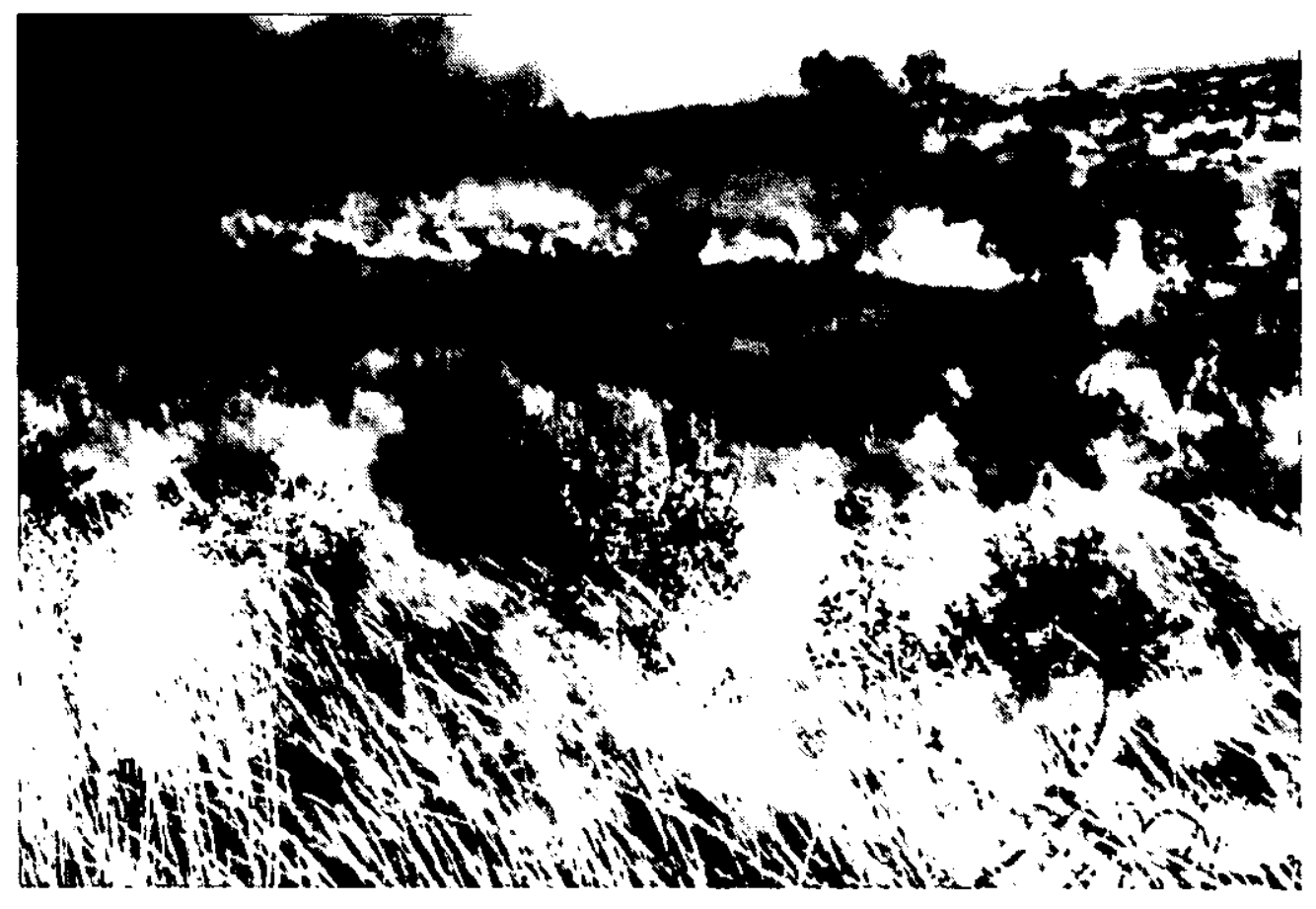

Plate 8.1 Fire lit in spinifex as people walk across plains

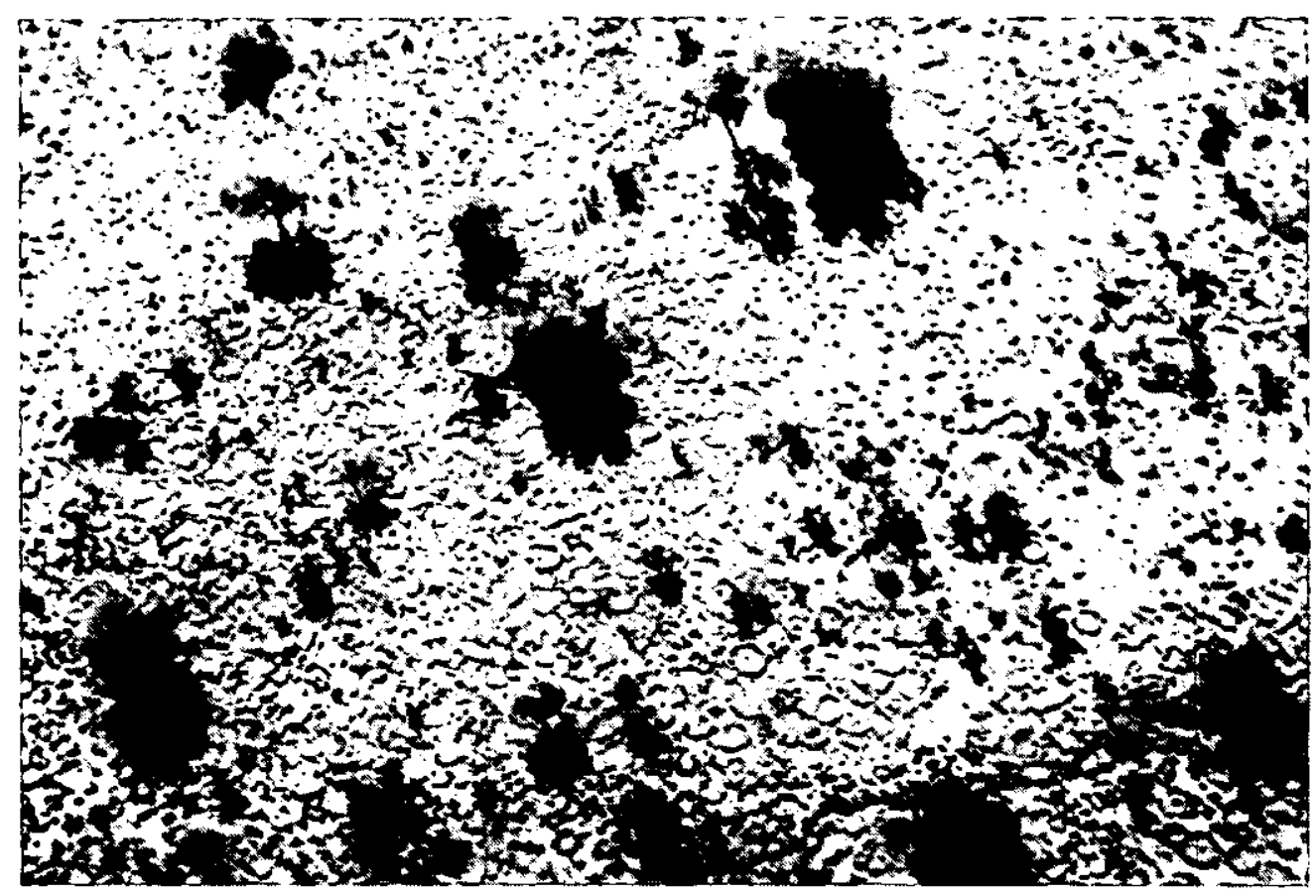

Plate 8.2 'Rings' of spinifex ready for burning 
The value of fire to subsistence hunter-gatherers manifests itself in other ways as well. The overall benefits are best exemplified by describing the sequential advantages to Aboriginal people following initial burning. Once a fire has been lit, the most immediate effect is that the smoke produced provides a means for communication. One of us (Cane) has been in situations where smoke from large fires has been seen $120 \mathrm{~km}$ away. Such smokes are used to signify the presence and activities of others. Smokes tell different Aboriginal groups if somebody is out hunting, or if people are approaching or if a group is travelling to a particular waterhole. Today, as in the past, smokes provide a means of identifying the presence of others. A humorous incident from the Mackay aerial expedition at Ilpili in 1930 highlights this:

\begin{abstract}
All the grass, trees and shrubs that had been cleared to make the aerodrome had been stacked in various heaps about the perimeter of the strip and were to be used as signal smokes for the aeroplanes... When Bob [Buck] put up his first smoke... it was answered north, south, east and west by Aborigines' fires, which would have made it impossible for the machines to pick the correct position of the aerodrome. 'Bob' sent frantic messages through black interpreters to all the country around that no fires must be lit until the great birds came (Kimber 1982:52).
\end{abstract}

\begin{abstract}
The fire itself kills and maims many insects and clears the ground exposing these and living insects to birds - particularly raptors and bustards. When burning, Aborigines anticipate the arrival of bustards soon after the fire dies out and usually go out hunting them the following morning and for several days after the fire has died out. On one occasion Cane (1982) recorded 27 birds feeding on freshly burnt ground and on other occasions flocks of between eight and 23 birds. Freshly burnt ground is also excellent for goanna hunting. When the fire clears the vegetation goanna holes are much easier to find and during fire the heated sand appears to 'trick' the goannas out of hibernation for a short time - thus causing them to leave fresh tell-tale tracks to their burrows. About 7-10 days after the fire has stopped burning the grass and spinifex begin to regrow producing soft nutritious shoots. This regrowth attracts and localises game from a wide area. These are then easily hunted by Aboriginal men. The birds, goannas and kangaroos are the immediate advantages of $f i r e$ and for the few months following initial burning the country is intensely foraged over by Aborigines looking for reptiles, feeding bustards and kangaroo. Following this first stage it is not until the following year that plants have regenerated sufficiently to produce fresh tubers, seeds and fruits for collection. Acacia trees regrow more slowly and begin to produce seed in the second year. Seed production peaks by year three to four and decreases slowly over the next 10 years. One species for example (A. pulchella; which does not grow in Central Australia) produces a maximum of 12,000 seeds at year three or four and decreases to only about 2,000 seeds per plant by its 13th year (Doran et al. 1983:18). Thus during the second stage after burning the Aborigines enjoy the value of open country, easy goanna hunting, relative abundance of grass and acacia seeds, tubers and fruits. However after about five years this productivity declines and spinifex bushes expand from the central tuft and overtake most of the other small plants and grasses and thus decrease the overall productivity of the landscape. After about five years the spinifex bushes have expanded
\end{abstract}


sufficiently to Aborigines need 8.2). carry another fire and it is about this time that the to reburn the country and begin the cycle again (Plate

The Aborigines burn the country repeatedly but as spinifex growth is irregular - (not all spinifex bushes are in contact with each other)- it is difficult to get fires to run over more than three hectares at a time. This factor - added to the fact that different parts of the country are burnt at different times of year and because regions regrow at different rates, means that a mosaic of country in different stages of regeneration is normally spread through a given hunter-gatherer range. This mosaic has economic benefits to Aborigines as it protects the country against hot wild fires which may destroy plants - killing the roots and burning the seeds and it means the foraging environment is diversified. Some parts of the gathering environment may be 'fresh burnt' attracting birds and game, others may be easily in the second stage - providing tubers and solanum fruits, others may be late in that stage, producing maximum quantities of Acacia seeds. Others may be close to reburning - with many dead trees for firewood and large trees for making implements.

Given this regime it is easy to see how fundamentally important fire was to Aboriginal people in the past. Not surprisingly fire continues to be important at outstations where people continue to use traditional bush foods. From an environmental point of view sandplains are the easiest to burn (because of the dominance of inflammable spinifex) and are the most profitably burnt (because of the presence of goanna and greater abundances of vegetable foods). Mulga woodlands must also be burnt in order to localise game but these must be burnt. less frequently and with more care. This is because large hot fires may kill existing trees and if followed too soon by a second fire regrowth can be destroyed as well (Shaw 1983). This risk is exacerbated in some regions today because the population of rabbits is high. These already eat new seedlings and destroy future trees and ground cover. Too much fire can compound this environmental problem. In mulga woodlands the combination of extreme fire and rabbits has the potential to wipe out existing vegetation - turning relatively fertile areas into dustbowls. These regions require careful range management if their fertility is to be ensured for the future.

In the course of our field work it was apparent that huge areas of ground were being burnt within the Pintupi, Luritja and Walpiri Homelands. This is because so much of this country is sandplain and can be profitably and easily burnt. In these regions bush tucker continues to constitute a significant part of outstation diets and the Aborigines burnt the country vigorously to maintain this component of their economy. These people are living up to their claim that they wish to 'look after their country' and continue the important traditional subsistence methods. Burning is not as widespread in the Pitjantjatjara, Nganyatjara and Yangkuntjatjara Homelands. This is partly because much of the country is open alluvial plains which are not as effectively burnt as the sandplains. But it is also because the people do not pursue the traditional methods of subsistence with the same sort of vigour as their northern countrymen. As we were told by a Pitjantjatjara man 'people do not walk around now' - meaning the Aborigines in the southern areas do not get goanna, that vegetable foods are less important in the economy and game can be effectively hunted, without fire, from the seat of a toyota. 
Table 8.10

Major contemporary bush foods and their cultivation potential

\section{Seeds}

Acacia coriacea

Tubers

Cyperus bulbosus

Ipomoea costata

vigna lanceolata

Fruits

Capparis lasiantha

Capparis lorantifolia

Carissa lanceolata

Cucumis melo

Ficus platypoda

Santalum acuminatum

Santalum lanceolatum

Solanum centrale

Solanum chippendalei

Solanum diversiflorum

\section{Nectors}

Acacia anuera

Grevillea aff. eriostachya

Grubs and insects

Acacia kempeana
Acacia hilliana
Camponotus sp.
Condonocarpus
contifolius
Eucalyptus aspera
" microtheca
terminalis

Artefacts

\begin{tabular}{ll}
\hline Acacia anuera & Mulga \\
Acacia dictyophleba & - \\
Erythrina vespertilio & Bean tree \\
Eucalyptus & \\
camaldulensis & Redgrum \\
Eucalyptus terminalis & Bloodwood \\
I microtheca & Coolibah \\
Pandorea doratoyxylon & - \\
Triodia pungens & Spinifex
\end{tabular}

Bush onion
Bush potato
Native Yam

wild orange

Koulke berry

wild cucumber

Wild fig

Quandong

Bush plum

Bush tomato

" "

Mulga

Honeysuckle

Witchetty bush

wattle

Honey ants

Desert poplar

Coolibah

Bloodwood

Spinifex

$?$
Y Seeds roasted Sand plains

$\begin{array}{lll}\text { Y } & \text { Tuber roasted } & \text { Creeks } \\ \text { Y } & \text { Tuber baked } & \text { Sand plains } \\ \text { Y } & \text { Tuber baked } & \text { Creeks }\end{array}$

Fruit eaten

$$
\begin{aligned}
& \text { Mulga wood- } \\
& \text { "land " } \\
& \text { Swamp margins } \\
& \text { Mulga w/lands } \\
& \text { Rocky ground } \\
& \text { Creeks } \\
& \text { " } \\
& \text { Sand plains } \\
& \text { " " " }
\end{aligned}
$$

Alluvial plns

Sap

Sand plains

Nector

Mulga

woodlands

Shallow, gravelly sand Mulga w/lands

- Honey

Sand plains

Near water

Sand dunes

Wasp gall

$\begin{array}{ll}\text { Many Alluvial plns } & \text { Alunting spears Sand plains }\end{array}$

Hunting spears Sand plain
Y Softwood (tshade) Creeks

- Model animals Creeks

- Wooden dishes Sand dune

- " " Creeks

- Spears Hills

- Adhesive Sand plains 
Table 8.10 continued

Habitat

\section{Tobacco}

Nicotiana spp.

Grevillea stenobotrya

Reptiles

Aspidites spp.

Tiliqua

multifasciata

Varanus acanthurus

Varanus giganteus

Varanus gouldii

Birds

Dromaius

novaehollandie

Eupodotis australis

Game

Felis catus

Macropus robustus

Macropus rufus

Oryctolagus

cuniculius
Pythous

Blue tongue

lizards

Goanna

Perentie

Goanna

Emu

Bustard

Feral cat

Euro

Red kangaroo

Rabbit
- Baked

- n

- n

- "

-

$-$

-

$\begin{array}{ll}- & n \\ - & n \\ - & n\end{array}$

Rocky ground Alluvial pln

Notes: * potential for cultivation:

$$
\begin{aligned}
& \text { Y definite } \\
& \text { ? possible } \\
& \text { - no }
\end{aligned}
$$

\section{Contemporary Bush Resources}

Traditionally over 150 plant resources as well as many different types of birds, insects, reptiles and marsupials were gathered and hunted by desert Aborigines (Cane 1984, Cane and Stanley in press; Latz 1981, Latz and Griffin 1978; O'Connell et al. 1983; Peterson 1978; Meggitt 1982). However with the introduction of European foods and materials this list is now somewhat smaller. The more difficult and tasteless bush foods have been replaced with European food and material objects such as digging sticks, twine, head pads, sandals and stone tools, have been replaced with European materials. Now there are about 50 native plants and animals which are used frequently by Aboriginal people. These are listed in Table 8.10 and include edible seeds, tubers, fruits, nectars, and wooden implements. In addition to these items of continuing economic importance there are various other plants and animals. These include small birds, reptiles and marsupials. These are not actively gathered and generally only taken if encountered when out hunting. They have little contemporary economic importance and need not be discussed here. 
$\underline{\text { Seeds }}$

Traditionally seeds were an important supplement to the diet of Aboriginal people and in the old days the Aborigines used to collect 40-50 Eucalyptus, Acacia and grass seeds at different times of the year (O'Connell et al. 1983; Cane 1984). Most seeds, however, were hard to process, requiring up to six hours labour to produce enough food for one person per day (2000 Kcals: Meehan 1977). Consequently this component of the traditional Aboriginal diet was dropped from the diet very quickly when processed flour was introduced as an alternative (O'Connell and Hawkes 1981). The only evidence we saw for the contined consumption of seed was a grindstone apparently used for seed grinding at Tjila Well; $4 \mathrm{~kg}$ of seed at Yumurrpa and a claim that seeds of dogwood were still eaten by some Walpiri people (and we suspect by some Pintupi people also). In many respects it is unfortunate that seeds have become so unimportant today. They are particularly abundant and very nutritious, comparing favourably with domesticated grain and bread, and some of the large seeds such as dogwood which could be roasted rather than ground, yield very high calorific returns. O'Connell et al. (1983) record returns from dogwood seeds as high as 4000-5000 Kcals an hour (enough food for two people for a day).

With respect to the nutritional value of important wild grass seed it is apparent that they have an approximate calorific value of $400 \mathrm{Kcal} / \mathrm{lo0g}$ and contain about $12 \mathrm{~g} / 100 \mathrm{~g}$ protein and $40 \mathrm{~g} / 100 \mathrm{~g}$ carbohydrate (Cane 1984 ). This compared to maize and barley which contain about $350 \mathrm{Kcals} / 100 \mathrm{~g}$, $10 \mathrm{~g} / 100 \mathrm{~g}$ protein and $70-80 \mathrm{~g} / 100 \mathrm{~g}$ carbohydrate (Thomas and Cordon 1977 ). Traditional bush damper made from wild seeds also compares favourably with processed flour and bread. Bush damper provides approximately 240Kcals/ $100 \mathrm{~g}, 30 \mathrm{~g} / 100 \mathrm{~g}$ protein and $50 / 100 \mathrm{~g}$ of carbohydrate. Flour and bread contain between $250-300 \mathrm{Kcals} / 100 \mathrm{~g}, 7-1 \mathrm{lg} / 100 \mathrm{~g}$ protein and $50-72 / 100 \mathrm{~g}$ carbohydrate. With respect to the abundance of seeds Doran et al. (1983) estimate there are up to $12 \mathrm{~kg}$ of mulga seeds per hectare. This is equivalent to 62,844 Kcals (using Peterson 1978 analysis) or enough food for five people for six days. Mulga, along with other important seeds (Portulaca spp., Panicum decompositum) are abundant on the alluvial plain but most of the edible seeds (Acacia coriacea, Panicum, Eragrostis, Fimbristylis) are found on the sandplains.

Given the abundance and nutritional value of wild seeds it is unfortunate that they are no longer processed by the Aborigines. The reasons for this, as mentioned above, is that seed processing was a time consuming and difficult task. Traditionally the process fell into four stages: seed collection, winnowing, grinding, baking the damper (see o'Connell et al. 1983; Cane 1984). Among these steps, seed grinding is the most diff $\overline{i c u l t}$. Aboriginal women can gather the seeds quite effectively and some are collected naturally into large piles by ants. The older women are also very efficient at winnowing the seeds clean, but the grinding is long, back breaking work. If this step in the process could be made more efficient, wild seed foods could again become a viable modern food source. Traditionally women used a simple pestle and mortar to grind the seeds and if this implement could be replaced with a more efficient tool such as a rotating grindstone like those used by Nepalese peasants, or preferably a simple manual mechanical grinding apparatus seed processing by Aboriginal people on outstations may become a viable economic option in the future. It may be possible for a body such as the Appropriate Technology section of the Community College of Central Australia to devise an efficient seed grinding mechanism and thus arrest the loss by Aborigines of collection and winnowing skills and provide them with a valuable economic option for the future. 
We can also see potential for cultivating some of the larger seeded acacias (particularly dogwood) which do not require grinding before they are eaten. To cultivate these trees one may only need to burn a few hectares around a camp and sow the seed after boiling them in water for 5-30 seconds and letting them cool (Doran et al. 1983). Acacia seeds are exported and planted extremely effectively in other countries and there is no reason why this could not occur in Australia as well.

At present the only economic value the Aborigines get out of wild seeds is pocket money from the sale of certain seeds overseas. Many overseas countries - particularly in Central Asia, the Mediterranean and Northern Africa buy Australian seed to get fast growing, drought resistant wood for fire wood, shelter, dust control, beautification of roads and town and to stabilize eroding ground. The most popular seeds from the desert are acacias (A. coriacea, A. holoserica, A. cowleana, A. anuera) and eucalypts (E. papuana, E. camaldulensis) (Midgely and Gunn 1983, Doran et al. 1983). The demand for seed is quite great, although it tends to fluctuate. At present there are seven government and 25 private suppliers of Australian seed. Aboriginal women are very good at collecting and cleaning seed for sale and get paid about $\$ 25$ a bucket for doing so. Resale value for seed is usually around $\$ 60-\$ 80 / \mathrm{kg}$ but some of the more valuable and difficult seeds to obtain (particularly E. camaldulensis) fetch between $\$ 200-\$ 300 / \mathrm{kg}$ (CSIRO pers. comm.).

It seems to us that as the viability of this enterprise often relies heavily on Aboriginal labour it would be possible for some Aboriginal organisations to capitalize on this market. To do so they would need to establish reliable stock piles of seeds in order to provide regular, prompt supplies of seed when needed and perhaps travel to market countries to establish and maintain contacts. The advantage to the Aborigines would be the involvement of women in an activity which may be quite acceptable as it requires semi-traditional skills and could provide an alternative income supplement. When approached by people to obtain seeds at present the Aborigines do so with great enthusiasm - often returning with tonnes of seeds by the bucket within days of the initial request.

Fruits

Most of the fruits eaten traditionally are still eaten today. The most important are bush tomatoes, konkle berries, wild figs, bush plums and quandong. All except two species of bush tomatoes (Solanum chippendalei and $S_{\text {. }}$ diversiflorum) can be eaten without processing. Those that requi re processing need only be opened and have their seeds cleaned out before the flesh is eaten. The fruits are found in various habitats. Wild figs grow on rocky country. Bush plums and quandong grow along creek iines. Bush. tomatoes grow on the sandplains and on alluvial flood plains. Konkle berries grow on the alluvial plains. All the fruits ripen during winter and spring and have a wide geographic region. Exceptions here are two species of bush tomatoes with large fruits (s. chippendalei, S. diversiflorum) (Plates 8.3, 8.4), which are only found in the northern Pintupi and Walpiri Homelands, and quandong which only grows in the southern homelands.

Bush tomatoes are by far the most important of the native fruits. They respond well to fire and are quick to colonize disturbed ground around outstations and along roadsides. They are tasty, nutritious and easy to obtain. They can be collected at a rate of $5 \mathrm{~kg} /$ hour thus yielding over $9000 / \mathrm{Kcals}$ - or enough food to feed four people for a day for only one 


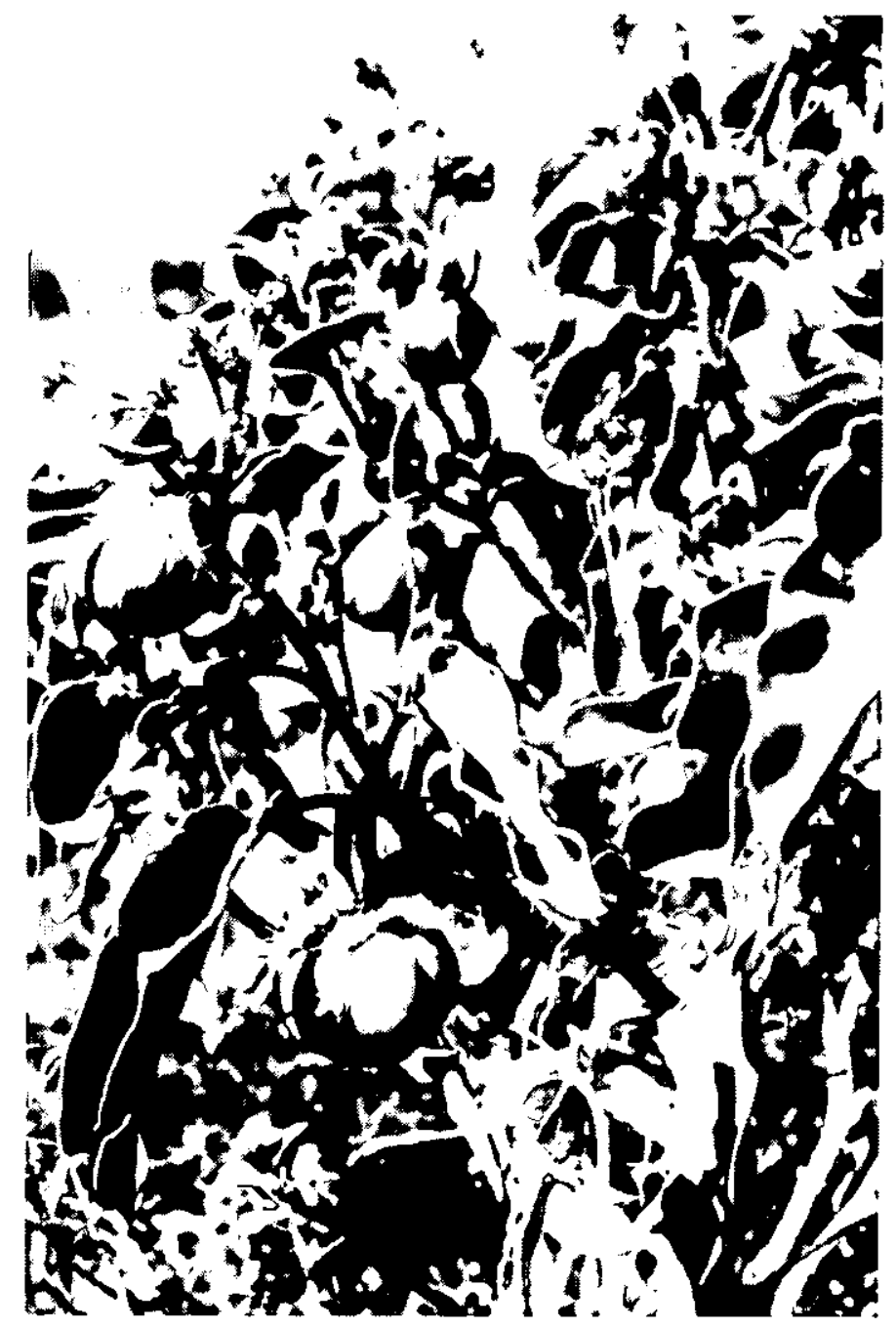

Plate 8.3 Large solanum fruits ready for picking

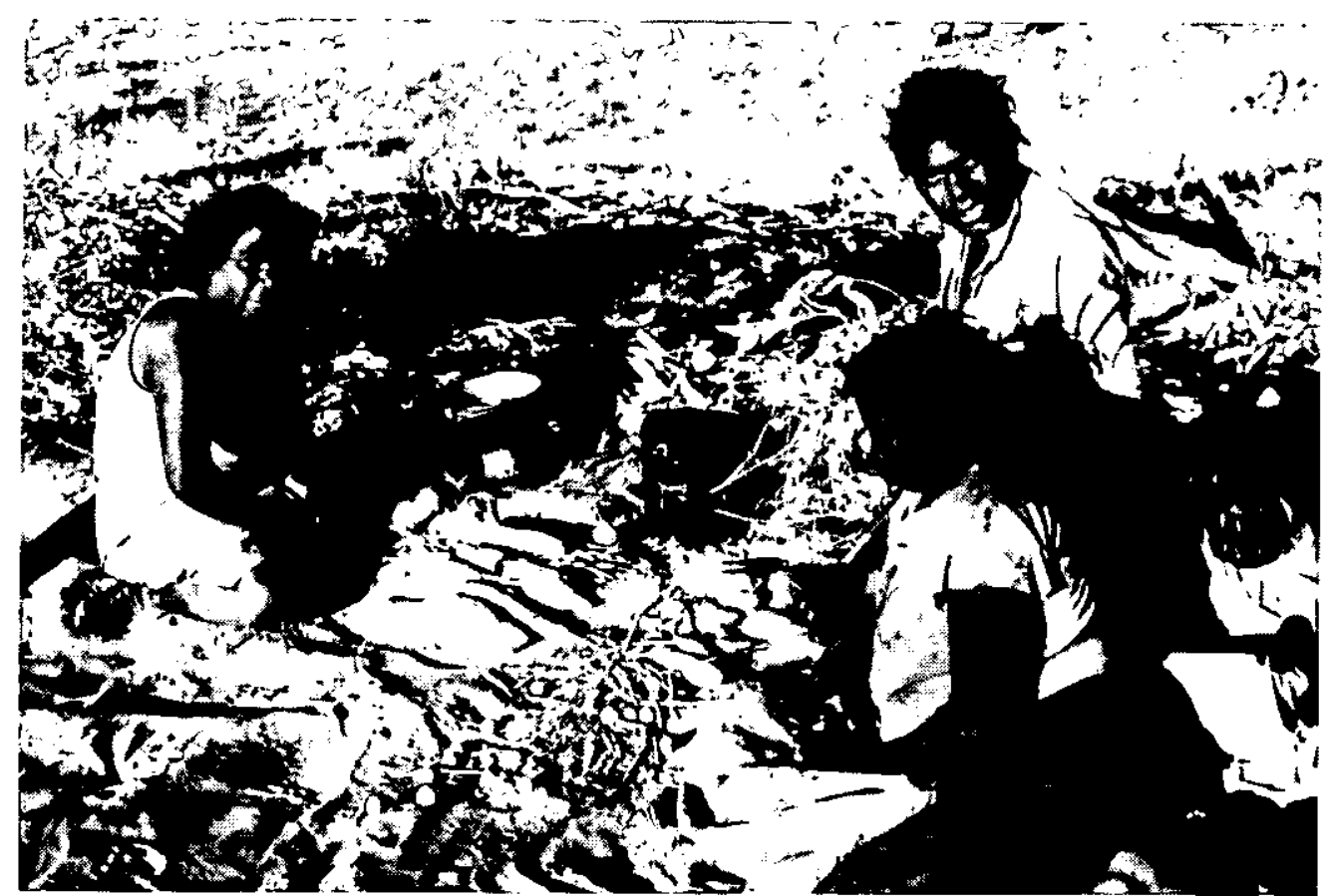

Plate 8.4 Pintupi people with a collection of bush potatoes (large), native yams (skinny) and bush tomatoes (round) 
hours' work (Cane 1984). Solanum fruits also have high nutritional value and contain high levels of vitamin C. For example Solanum chippendalei and s. centrale contain approximately $5 \mathrm{~g} / 100 \mathrm{~g}$ of protein, $20 \mathrm{~g} / 100 \mathrm{~g}$ carbohy $\mathrm{d}$ rate, $35 \mathrm{mg} / 100 \mathrm{~g}$ ascorbic acid and between $100-200 \mathrm{Kcals} / 100 \mathrm{~g}$ of fruit (Cane 1984; Peterson 1978). This compares to oranges and tomatoes which contain $\mathrm{lg} / 100$ protein, $4-1 \mathrm{lg} / 100 \mathrm{~g}$ carbohydrate, $35 \mathrm{mg} / 100 \mathrm{~g}$ ascorbic acid and only $30 \mathrm{Kcals} / 100 \mathrm{~g}$ of fruit.

Because of the adaptability of solanums to environmental disturbances such as ground clearing and road clearance they have excellent potential for intensified domestication. This is already happening to a certain extent naturally as solanum fruits growing from spilt seeds readily colonise cleared areas around camps. There is no reason not to extend the distribution of solanums for hectares around camps, spreading seed systematically away from the camp and burning the plains to germinate the seeds. Using this technique the Aborigines could create bush orchards of different species of solanum fruits.

In the southern, colder homeland regions it may be necessary to experiment with some of the larger solanums which do not grow there naturally. The remaining fruits also need to be experimented with. We observed one large bush plum tree growing at Tjunti and imagine this species, along with quandong and konkle berries could easily be planted and grown in small groves at outstations. Wild figs may be more problematic because of their preference for sheltered rocky habitats, and because some southern Aboriginal groups consider the tree sacred (Coombs et al. $1983: 25)$.

Tubers and Bulbs

Three traditionally important tubers (Ipomoea costata, Vigna lanceolata, Cyperus bulbosus) (Plate 8.4) remain important in outstation economies today. Vigna and Cyperus tubers are found throughout the homeland region we visited - along creeks and in ground that is seasonally inundated with water. Ipomoea tubers grow on sandplains but are only found growing in the norther $\vec{n}$ Pintupi and Walpiri Homelands. All the tubers are easy to process: Cyperus bulbs are simply dug from the ground and cooked in camp fires; Ipomoea tubers are roasted and then baked in the ashes of fires (Plate 8.5). Ipomoea and Cyperus tubers are available all year, being most abundant during autumn and winter. Vigna tubers are only available during late winter and spring.

These foods, like other bush foods, are easy to gather and are nutritious. Cyperus bulbs can comfortably be gathered at a rate of $1000 \mathrm{Kcals}$ an hour (half a days food) and Ipomoea tubers can be collected at a rate of approximately.1,700Kcals/hour (Cane 1984). The best figure we have recorded was $6,345 \mathrm{Kcals}$ an hour (ibid.) and is comparable to gathering rates in the Alyawarra Homelands recorded by o'Connell et al. (1983:85). These returns are high enough to provide enough energy for three people for a day after only one hours work.

With respect to the nutritional value of these vegetables it is apparent that wild tubers compare favourably with their European counterparts. Ipomoea tubers and Cyperus bulbs for example contain between 30$60 \mathrm{~g} / 100 \mathrm{~g}$ carbohydrate and $130-277 \mathrm{Kcals} / 100 \mathrm{~g}$. Potatoes and onions by comparison contain between 8 and $22 \mathrm{~g} / 100$ carbohydrate and $150-180 \mathrm{Kcals} / 100 \mathrm{~g}$ of vegetable (Cane 1984; Thomas and Corden 1977). 


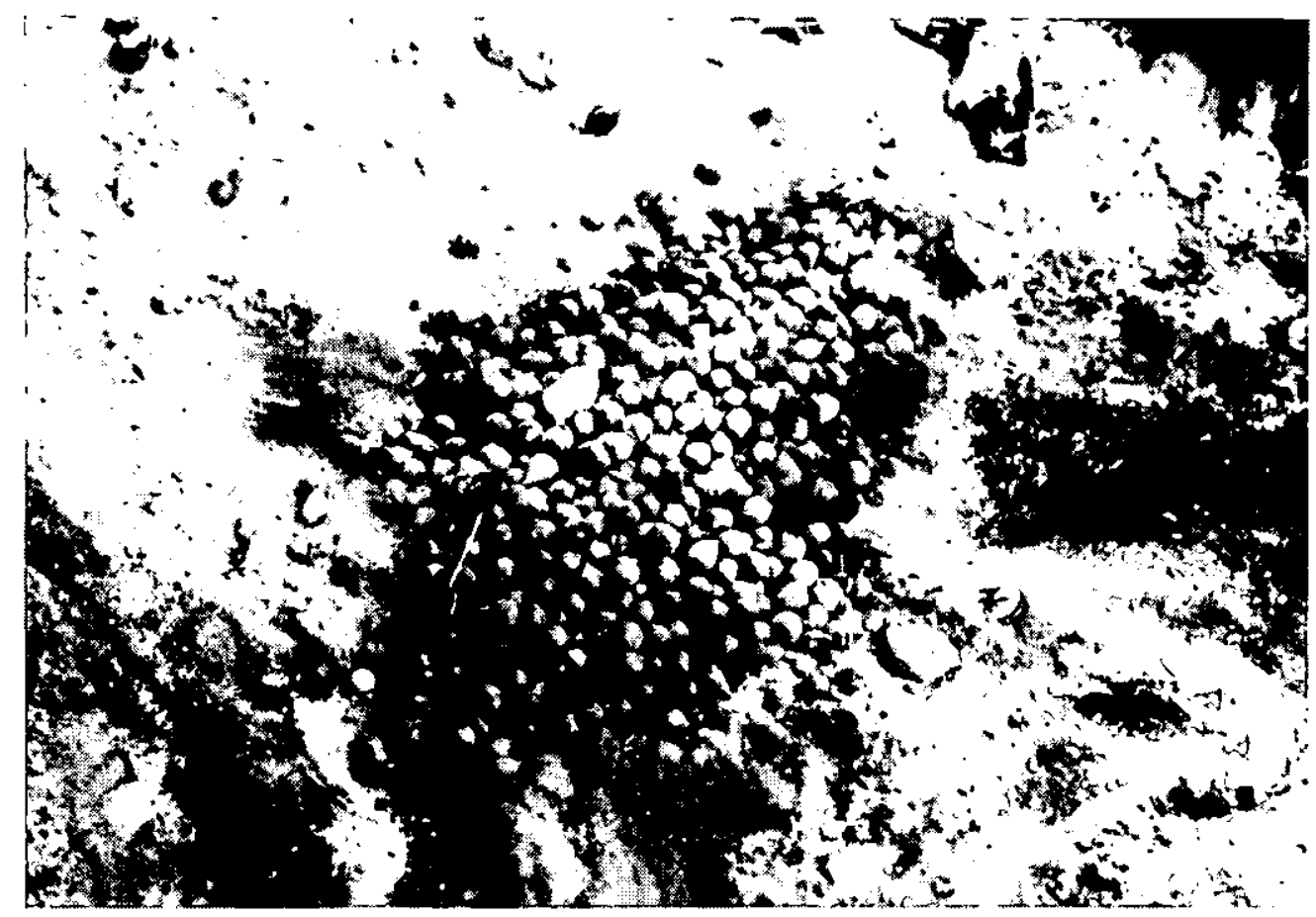

Plate 8.5 Cyperus bulbs roasting in hot sand and coals

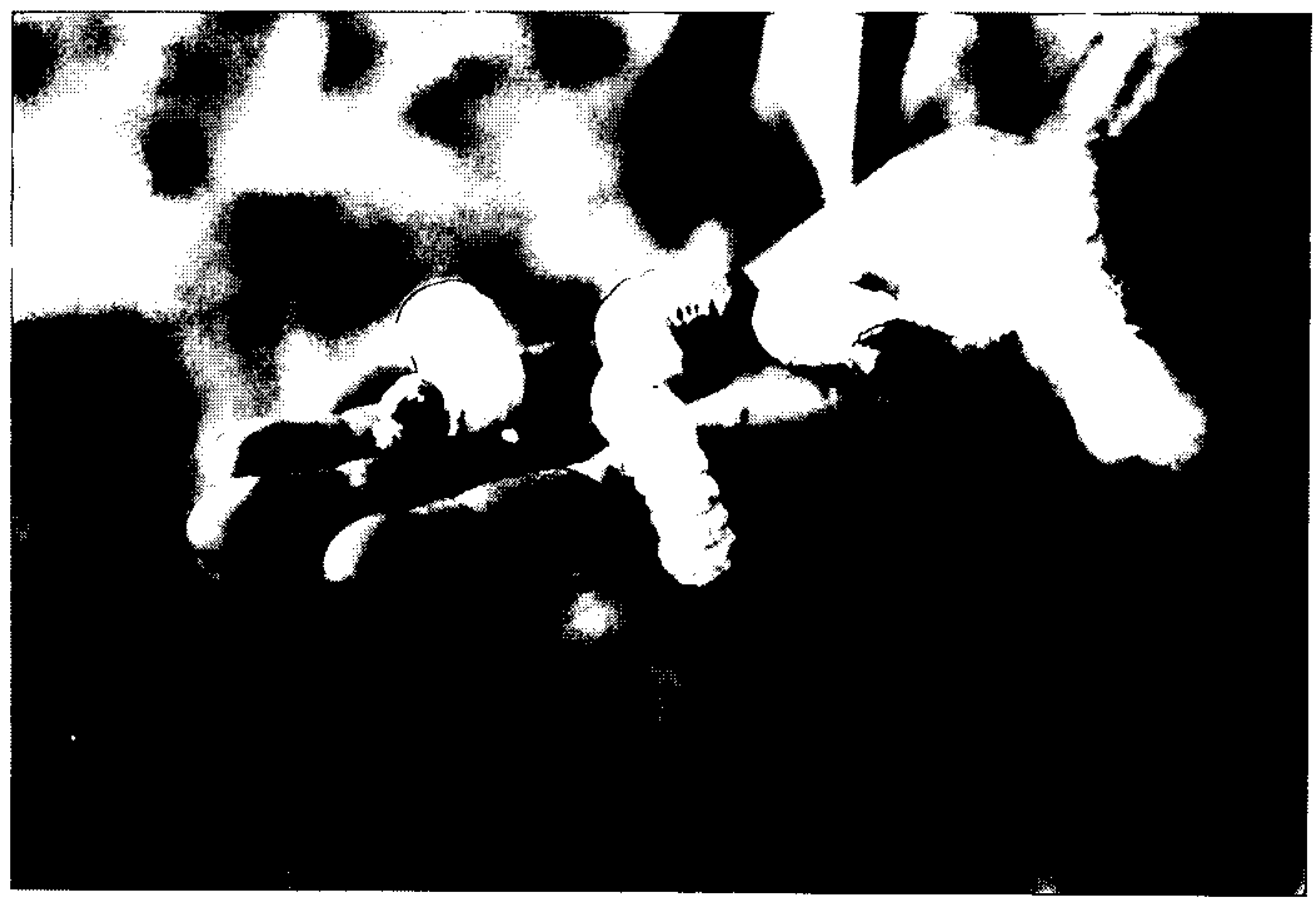

Plate 8.6 Witchetty grubs collected from a coolibah tree 
All three species of wild tubers would seem to have great potential for cultivation at outstations. Cyperus bulbs for example, usually live in clayey ground which is seasonally inundated with water and thus the bulbs may grow well around hand pumps, taps, watertanks and windmills where there is spillage and water flow. Ipomoea tubers may be more successful on sandplains around camps. We saw these colonizing cleared ground at Yariibalangu and have seen one mature plant in an outstation garden near Utopia although this may have been there when the garden was set up. Kimber (1976) recorded one man growing Ipomoea at $h$ is house in Papunya from runners collected in the bush. This would seem to be the best method of transplanting Ipomoea and is the method used to transplant them in the highland of New Guinea (Professor J. Golson pers. comm.; Professor D. Yen pers. comm.). Vigna tubers could possibly be grown at camps by transplanting runners in the same way, although we do not know if this has been tried. Among the three species, Ipomoea tubers probably have the greatest economic potential and we can foresee substantial colonies of these around northern outstations in the long term (10-15 years) - providing a substantial nutritional contribution to these camps. Ipomoea does not grow in the southern colder homeland regions. Plants have been grown and survived in Alice Springs but the likely success of their propagation at camps in more southerly regions requires experimentation. However, given the regeneration rates we have observed following fire in the wild it may be possible to plant runners after the cold season and harvest the tubers the following autumn, before winter frosts set in.

Insects and parasites

Edible insects are still harvested from six plants (Table 8.10). The most common are witchetty grubs and coconut apples which are wasp galls found on bloodwood trees. On the sandplains witchetty grubs can be found in coolibah trees but they are most abundant from the roots of witchetty bushes on alluvial plains in the Luritja, Pitjantjatjara, Yangkuntjatjara and Ngaanyatjara Homelands. Coconut apples are picked from the bloodwood trees (see peile 1980) and are widespread throughout the region.

Witchetty grubs are probably the most important of the insects, and traditionally were a major staple (Plate 8.6). Tindale (1953) records that these were eaten nearly every day by Pitjantjatjara people at certain times of year. In another instance he records that six boys gathered $226 \mathrm{~g}$ of grubs in an hour close to a camp where 400 people were living. We have data for grubs collected from coolibah trees at a rate of $30-40$ grubs $(400 \mathrm{~g})$ an hour. This gives a calorific return of about $1,000 \mathrm{Kcals}$ per hour (Cane 1984; see also O'Connell et al. 1983).

Wood

Many native trees still remain important in outstation economies. Local trees are used extensively for housing, fencing, firewood and making implements. Mulga is the most important and is commonly used for firewood and making implements. The most commonly made today are spears, shields, clubs, spear throwers and boomerangs. These are made for sale and personal use (see Brokensha 1975). The soft wood of the bean tree is also very important. The light wood is still used frequently to make wooden dishes, light shields and model artefacts for sale. The red beans from the trees are used for decoration. Spears are made from Pandorea doratoxylon and Acacia dictyophleba. The latter is a light resilient wood and is important to the Pintupi who trade it to neighbouring linguistic groups (Plate 8.7). Resin obtained from spinifex is still used throughout the region although 


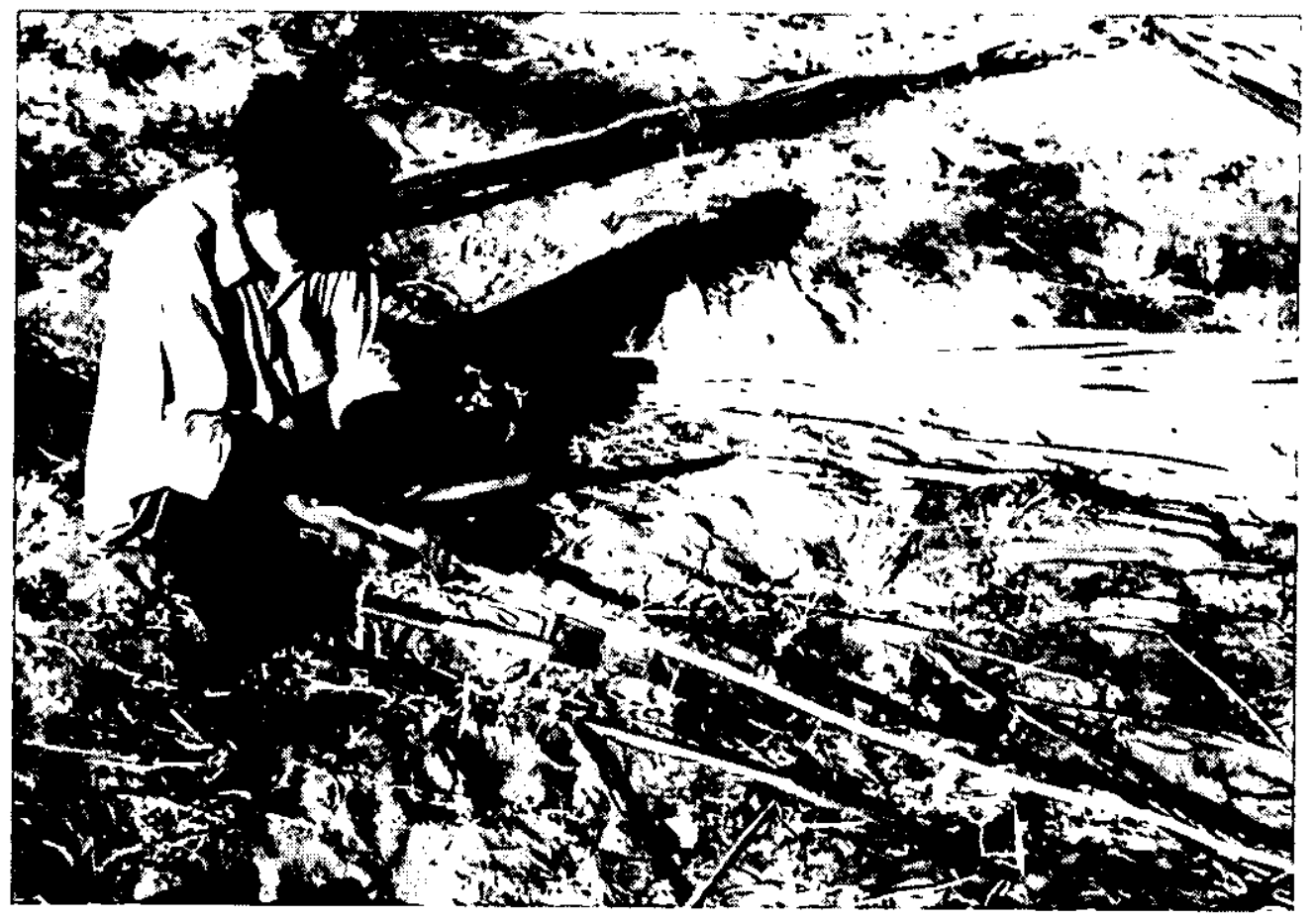

Plate 8.7 Pintupi man preparing spears for trade.

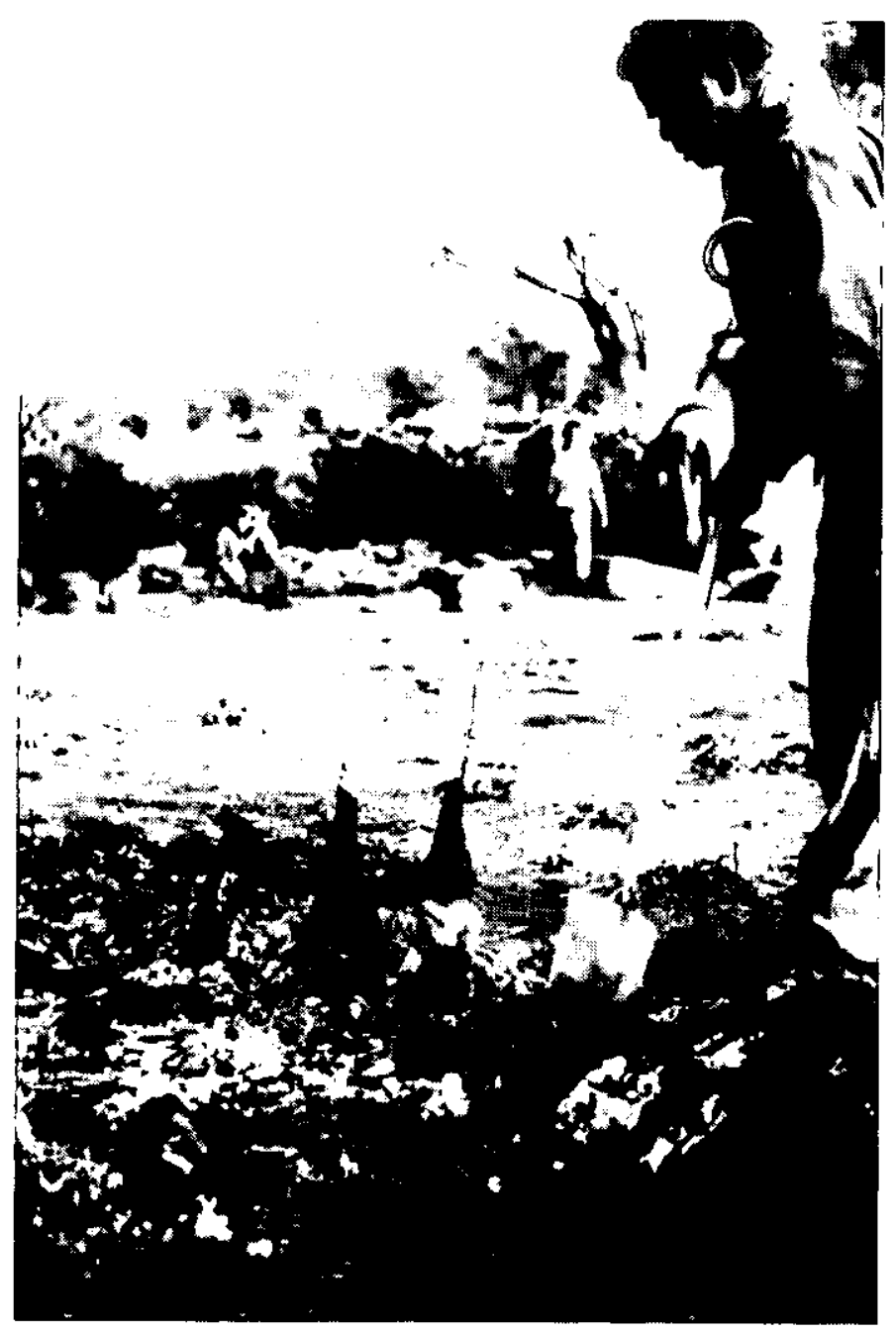

Plate 8.8

Kangaroo being baked in earth oven. 
it is occasionally strengthened with wire. In experimental tests with traditional spears Cundy $(1980)$ found that this was superior to its modern equivalents.

The roots of red gum trees are dug out and used to make wooden artefacts for sale. This activity provides a small supplement to outstation income - particularly at camps near Ernabella. The artefacts are sold through outlets at Alice Springs and Ayers Rock.

Animals

Traditionally a great range of small birds, marsupials and lizards were hunted by Aboriginal people. This situation has changed however. Children, for example, spend less time stoning small birds to eat. Feral cats have reduced the population of small marsupials (Firth 1978). The absence of fire has altered the ecological balance of the land, changing habitats and food supply and thus reduced the population of some species of wallabies (Bolton and Latz 1978) and probably other marsupials as well. Cattle and rabbit populations have denuded large areas of mulga woodland, reducing their carrying capacity for kangaroos. Chippendale (1963) for example recorded that the abundance and density of virgin range land in Central Australia fell by two thirds after only one year but even this was ten-fold that of country that had been grazed for many years.

Larger more abundant animals, such as bustards and kangaroo are still hunted vigorously. In regions where cattle and sheep population have not been introduced or have been absent for a long time (such as around Docker River, Ernabella and Mt. Liebig) kangaroos are quite abundant and easily hunted.

Populations of euros are still high in mountainous country with as yet minimal competition from feral goats. MacFarlane (1978) recorded that a traditional group of Aborigines living at Kutjuntari killed one euro every two days during the time he was there. This rate is much lower today because there are alternative food sources and men tend to shoot euro from toyotas and rarely pursue them (even wounded animals) over rocky terrain if they do not make a direct hit.

The number of emus in the homeland regions appears quite low. Gould (1969) recorded a group of traditional Ngaanyatjara people killing only five emus over a period of four months in a favourable location and we have not seen more than a dozen emus in our travels and have never seen the Aborigines catch any. Bush turkeys are still quite abundant - particularly in the remoter sandplain country in the north and west of the homeland regions visited. They are really easy to hunt and are very popular.

Goanna are still avidly collected in the sandplains and dune country of the Luritja, Pintupi, Walpiri Homelands but are less frequently taken in the Pitjantjatjara and Yangkuntjatjara Homeland regions. They are most nutritious during the winter when they contain large deposits of fat used in hibernation, but are most easily caught during spring when they come out of hibernation and tell tale tracks give away the location of burrows. Goanna are easy to gather and can be collected at a rate of about $730 \mathrm{~g} / \mathrm{hour}$ - or 2,100Kcals an hour (Cane 1984). Thus one person can collect enough food for one day in about an hour.

In the northern homeland regions and at camps located in sandplain terrain goannas constitute the main source of bush protein. In the southern 
region, at camps located in mulga woodland kangaroo are more plentiful and are thus the main source of bush protein. Major supplements to the traditional meat foods are feral cats and rabbits. These are both popular and abundant in homeland regions - although rabbit populations were low in the Pintupi and Walpiri Homelands. Both these animals were in the desert before the arrival of Europeans in the Western Desert (Carnegie 1898:214) and the Aborigines thus consider them a traditional food supply.

All the animal foods are cooked in more or less the same way. They are all gutted, legs dislocated, skin roasted (or fur burnt off) and baked in shallow ovens dug into the ground and filled with hot coals (Plate 8.8). Larger animals are of ten eaten partially raw, blood is usually drunk and the intestines and intestinal fat are roasted and eaten.

Nutritionally bush meats are equivalent to European equivalents. Goanna for example is as nutritious as steak - with high levels of protein $(30 \mathrm{~g} / 100 \mathrm{~g})$, fat $(1 \mathrm{gg} / 100 \mathrm{~g})$ and calorific return $(300 \mathrm{Kcals} / 100 \mathrm{~g})$. Turkeys are also quite nutritious although their fat content also decreases during the winter and some can be pretty scrawny in the late months of the dry season. Large birds can weigh up to $13 \mathrm{~kg}$ and with a calorific return of about $160 \mathrm{Kcals} / 100 \mathrm{~g}$ yield up to $21,000 \mathrm{Kcals}$ - or enough food for 5 people for two days.

\section{Contemporary Importance of Bush Resources}

In the course of our investigations we estimated that traditional bush foods constituted up to 50 per cent of the diet in traditional pintupi camps, between 20-30 per cent of the diet of most Walpiri and Luritja camps and 10-15 per cent of the diet at less traditional camps around Docker River and Ernabella (Table 8.11). These proportional estimates are drawn from casual observations at each camp visited. At each camp we recorded the foods we saw being eaten and the food remains at camps. We also took note of the surrounding environmental conditions and talked to local Aborigines about the types and quantity of bush foods eaten. From this composite picture we estimated the likely intake of bush foods for different regions. We were not at any camps or in any regions long enough to make detailed quantitative recordings and we cannot quantify our estimates in terms of relative nutritional contribution of bush foods compared to European foods (e.g. Altman 1984). Rather, given the available evidence our estimate is based on the likely number of meals provided by bush foods, compared to those provided by store foods. For example we would expect outstation people in the vicinity of Ernabella to get at least one kangaroo a week - probably each weekend. Thus, with additional supplies of witchetty grubs and tubers and rabbits we feel it is no exaggeration to assume bush foods feed Aboriginal people for at least one day out of a week (i.e. 15 per cent of the time). At most of the outstations we would expect this percentage to be higher - in the Walpiri, Luritja and Pintupi camps bush foods generally constitute one meal out of four - or one days food out of four ( 25 per cent of the food eaten).

This is obviously only a generalised figure and we are aware of seasonal and weekly fluctuation in the relative importance of bush foods (see below). Nevertheless, we believe these estimates are quite reasonable. To get more precise data one would need to conduct extended case studies in different regions. Currently there is inadequate data to determine exactly how important the renewable bush is economically to Aboriginal people and what its long term carrying capacity may be. What needs to be determined now is the size and distribution of respective animal and vegetable popula- 
tions, the number of plants and animals harvested and accurate weights of meat and vegetables obtained. We also need to know the types of food favoured by the Aborigines, the distances people travel to get food and the seasonal availability of bush foods. We also need to assess the impact outstations have on their local hunting and gathering environment and determine the maximum sustainable yields of major foods. It may be also necessary to develop techniques to increase harvest above present levels. Other factors which need precise investigation include the weekly variation in the amount of bush foods consumed at outstations given variables such as availability of vehicles, proximity to stores and regularity of paydays.

We have attempted to answer some of these questions in this report, but given our original goal of defining the general characteristics of land use practices at outstations and other considerations outlined in the introduction we have not been in a situation to conduct detailed case studies. Such research clearly needs to be done as the value of renewable resources such as food, water, fibre and power to the Aboriginal people in the long term ( 50 years) may well exceed that of mineral and other nonrenewable resources (Dacks 1981:168) and become fundamental to the survival of outstations.

Returning to our original task of assessing the current importance of bush resources to the outstations visited it is apparent from the regional profiles summarising outstation characterisitics in each chapter, that there were only two ( 6 per cent) at which bush foods were thought to make a major dietary contribution. Fourteen camps ( 44 per cent) used bush foods to a moderate degree whereas there were 15 ( 47 per cent) camps at which we estimated that bush foods were of minor importance. This data accounts for 32 camps and excludes those camps which appeared to be abandoned at the time of our visit. Given the data already presented in this chapter it is apparent that bush foods make an important nutritional contribution to people living on outstations. However, this can be highlighted by examining the relative contribution of bush foods in monetary terms.

For example, we estimate that the weighed average of bush tucker consumed per person at the camps in use is 23.4 per cent of the total diet. If this, as a percentage, of the weekly amount spent on food ( 80 per cent of annual income of $\$ 2,500$ per head $=\$ 40$ per week) is calculated then the value of bush tucker is $\$ 616$ per person per year. Thus, given the estimated population of outstations in use during our visit (442 people) this amount means that the value of bush tucker to the outstation population is $\$ 272,130$ per year! Clearly this is a substantial figure, highlighting the economic value of continuing traditional patterns of subsistence. We imagine that it would be difficult to match the economic benefits of bush production with any alternative European enterprise such as horticulture, grazing or artefact sales.

Naturally the value of this bush tucker has to be set off against the cost of obtaining it - a cost that can also be quite substantial. This can be exemplified by our own experience. In the course of our field work we made four hunting trips. On these trips the Aborigines shot six rabbits, five kangaroo (two large males and three females) and three bustards. This equals approximately $282 \mathrm{~kg}$ of meat (Calaby and Frith 1978; Cane 1983) as the Aborigines eat all the meat, bonemarrow and intestines. To replace this amount of meat with tin meat bought from a store $(\$ 1.10$ per $250 \mathrm{~g}$ tin, Young 1984) would cost $\$ 1,240.80$. However during the hunting trips we spent about $\$ 25$ of petrol, got two flat tyres ( $\$ 16.00$ to repair) and had one blow out ( $\$ 250$ to replace). Thus, while the hunting trips were very 
profitable they cost us $\$ 291$. Nevertheless the value of bush foods in financial terms alone (excluding the nutritional, social and recreational benefits) is clearly quite substantial. Since hunting is regarded as a pleasurable pastime, labour cost can be regarded as nil. Furthermore, if the cost of heating and cooking facilities obtained from the bush at outstations could be measured in monetary terms this would also add substantially to the economic benefits of the bush environment. Current heating and cooking are virtually free - being done with fire wood collected with ease from around camps. Without stretching the point too far we could also look at the cost of replacing traditional Aboriginal shelters currently used at camps. During our visit there were 131 traditional and semitraditional shelters in use and to replace these with the most basic shelters (first stage houses: $\$ 4,000$ each) would cost $\$ 524,000$. Consequently in terms of housing and food alone traditional bush resources provide an economic supplement equivalent to $\$ 964,000$. This stresses the necessity of encouraging and maintaining the traditional patterns of subsistence currently in use at Desert outstations. (Although we are not advocating that houses should not be provided for the sake of saving money.)

The role of bush food in individual economies naturally varied from place to place and from time to time. We found several interrelated factors such as mobility, access, seasonality and geographic distribution influence this. Generally people travelled to the main communities on pay day and bought bulk food. Over the next two weeks as money and stores ran out the quantity of bush food consumed at camps generally increased. The proximity of camps to stores also influenced the quantity of bush food collected. store food generally required less effort to obtain and was thus more popular if access to stores was not too difficult. Thus camps which were close (within $30 \mathrm{~km}$ ) to communities and food outlets (Nyirrpi, Mt. Liebig and Kintore) consumed more store food than camps which were relatively remote. Toyotas also influenced this balance. These worked in two ways. On one hand their availability meant people could travel more freely and consistently to get stores, but they also meant that the Aborigines could travel more extensively to get bush foods. The same pattern existed when camps were visited during weekends by friends and relatives. These visitors often brought store food with them but also frequently came out specifically to get away from the community and go hunting and gathering. They provided transport for outstation people to go with them.

The seasonal availability of bush foods also has a marked impact on the food consumed at camps. The summer is usually the worst time to collect bush foods. Wet season rains make the country quite impassable, herds of kangaroo spread out with the abundant water and most of the tubers and fruits have not yet grown. Goannas and witchetty grubs can still be gathered and honey ants are available and these are collected avidly. During the dry season, particularly winter and spring, food supplies are best. Most of the fruits and tubers are available, goanna comes out of hibernation and populations of large game contract around large waterholes (Cane 1984; Peterson 1978; Gould 1969).

There are also major regional and topographic variations in the availability of different foods. Camps located on the sandplain, for example have access to greater quantities and varieties of plant foods and goannas whereas camps in the mulga woodlands have better access to large game, witchetty grubs and rabbits. On a north-south basis, the northern camps have better access to vegetable foods - notably Ipomoea tubers and bush tomatoes whereas the southern camps have but two southern fruits, quandong and kurrajong and greater access to honey ants, witchetty grubs and game. 


\section{Concluding Remarks}

Summarising the section above it is apparent that bush foods remain an important economic component of outstation life. This importance can be measured in several ways ( nutritional, health, cultural, recreational) and all reveal the vital role of continuing traditional subsistence strategies in outstation communities today. To capitalise on bush resources it is important to select the location of outstations carefully so they have access to the combined resources of the sandplains, hills and floodplains. If camp locations are carefully selected Aborigines can get maximum benefits from the bush - having access to plentiful supplies of tobacco, ochre, figs, euros, water (on the hills), hardwood, firewood, game, tubers and fruits (on the creeks and alluvial plains) and fruits, tubers and goanna (on the sandplains).

Currently there is a tendency for some outstation development to be ad hoc; along road sides and near old cattle bores rather than where the potential productivity of the land is high (e.g. Tjila Well, Yumurrpa, Emu Bore, Waylilinypa, Yaribiilangu). Some camps are located next to important waterholes (Tjukula) but in poor country. The mythological importance of some regions are important reasons for setting up outstations but Aborigines generally do not wish to live too close to sacred sites for fear of women and children seeing them. Traditional estates are usually quite large consequently there is room for the effective planning for camps to be sufficiently spaced to allow effective hunting and gathering without putting too much pressure on the local environment. Thought must be given to this aspect of outstation development if the long term economic viability of camps is to be ensured.

Given the Aborigines' detailed knowledge of these bush environments it is not surprising to find that many camps are in fact located in suitably diverse ecological regions. Many of these camps are located in mulga woodland, with easy access to sandplains and hilly country. This is not the case so much in the Walpiri Homelands where most of the mulga plains is owned by pastoralists. Also, as the homelands movement has developed, much of the heterogeneous country in Central Australia has been settled. Future camps will thus have to begin settling more homogenous and less viable environments further west into the Gibson and Great Sandy Deserts. It is in these areas that care must be taken to locate outstations in the best possible environments. Naturally the quality of the bush environment varies. Some regions are 'proper rubbish' country and others are relatively fertile with the potential - if provided with permanent water - to support relatively high populations. It was such regions which were major ceremonial centres in the past. For example Cane (1984) reveals that the region north of the Stansmore Range in the Great Sandy Desert supported about 300 people when, there was sufficient water in the land. Equally high populations have been recorded by others. For example, in the Tanami Desert Gee (1911:20) recorded '150 male Aborigines holding a corroborree' and Carnegie (1898:369) recorded an encounter with 100 Aboriginal men near Gregory Salt Lake. Both these gatherings must have been accompanied by an equivalent number of women and children, thereby raising the population of each to at least 300 . Meggitt (1962:55) says groups of 400 to 500 walpiri attended ceremonies and records 300 pintupi seen together as recently as 1925. In other areas Gill (1968:11) recorded gatherings of 130 people, Tindale (1939:199) and Hackett (1937:289) recorded between 250 and 270 people and Strehlow (1947:65) recorded several hundred Aranda and Matuntara congregating for four to six months at a time. 
Obviously such areas need to be identified again and used as a focus for outstation development and other areas of potential productivity must be identified. Such areas could be located using satellite imagery and limited ground traverses. From this a predictive regional land use strategy could be derived and this may be of considerable use in the future development of outstations in remote desert regions.

Nevertheless, no matter where an outstation is located or how abundant the traditional resources are, the surrounding environment will become progressively depleted further and further from camps the longer each outstation is in existence. Obviously the better the local environment is in the first place the better it will stand up to long term use. However, we also consider there are two other options which may be taken to increase the viability of the environment surrounding desert camps. Basically these options include extending the range over which Aborigines can effectively hunt and gather and improving the value of the immediate outstation environments.

With respect to the first option it is apparent at present that outstation hunting strategies are largely restricted to what can be hunted from vehicles, and thus what can be caught from road sides. Aborigines also drive off roads into the bush but, more often than not, stick to old tracks, seismic lines, fence lines and roads. Often much of their hunting is done when simply travelling from place to place and consequently game is scarce along such well worn tracks. An alternative approach may be to develop a series of graded tracks connecting resource rich zones, places of mythological importance and major waterholes. Most Aborigines have detailed memories of traditional country, remembering which was 'good kangaroo country', 'good bush potato country' and it should not be difficult to link such resource areas by tracks. Within each network old soaks and waterholes could be reopened and could be used as transient camping places (much like Putardi Spring is used from Mt. Liebig at present). It would even be possible to place isolated rain water tanks or several 44 gallon drums at waterless, but resource rich locations. These would be filled naturally by summer rains and used by people as they systematically exploit different zones within their respective 'regional resource grid'. Such a network of resource roads would effectively provide the opportunity for a form of contemporary nomadism - capitalizing on both the traditional characteristics of the people and the technological conveniences of today to improve the quality of life for outstation dwellers. This would have several advantages. In the first place it would mean people on outstations would have access to previously inaccessible resources and, where bore water quality is poor, would provide an opportunity to get away and use surface water free of nitrate contamination. Obviously this would also increase the opportunity to exploit the environment, thus improving the nutritional status of the people and lessening the impact of hunting and gathering on the immediate outstation environment.

This option may be considered a little fatuous - Aborigines, after all, do go off road when they want to; they already know where the bush resources are and can drive to them if they want too. The trouble is, of course, that this does not happen. People do not tend to travel to remote places on their own. They do not drive long distances over rugged terrain simply to get a few tubers and goannas - to places where there is no water, or communication if they break down. The outstation movement itself exemplifies this. This movement did not develop until the country became accessible. People from Papunya did not go much past Yai Yai before there were decent roads. The Walpiri did not set, up Nyirrpi and the surrounding 
outstations until seismic lines were cut in the area. Likewise the movement south of the Kimberleys has only begun with the construction of seismic tracks. No outstations were set up around Ernabella before decent roads were graded.

The risk of such a strategy in the government's eyes may be that a network of new roads sparks a floresence of new outstations. This need not happen if each network of roads is focused on an existing cluster of outstations (such as around Nyirrpi or Mt. Liebig or Kintore) and does not meander of $f$ widely into the blue yonder.

The second option (which we see as additional rather than an alternative) is to increase the value and productivity of the local outstation environment. This may take longer to develop and originally require specific skills, experimentation and advice, but would aim, within the next five years, to see the cultivation and intensification of suitable bush crops at outstations. The advantages of these crops over European crops is that they are popular, nutritious and already adapted to the environment, (characterized by high summer temperatures, frosty winters, summer floods, prolonged drought, poor soils, fire and low water quality). Most of the crops we consider suitable have been detailed in the section on bush resources (Table 8.10 ). At present there has been very little experimentation with bush foods at outstations, but we feel this definitely warrants further investigation. This option has already been described by Latz and Griffin (1982), who list 30 species which may be suitable for cultivation. Coombs et al. (1983) list 41 species for possible cultivation and Maggs (1978) and MoIlison (1984) suggest other wild crops suitable for investigation. Clearly there is increasing interest in this aspect of outstation development.

Member for Stuart, Mr. Brian Ede, has supported a Government proposal for research into large-scale farming of native foods of central Australia.

He said the sweet potato was a native food which may prove to be commercially viable.

There was a lesson to be learned from the macadamia nut, a native food that was overlooked as a possible commercial product by Australians until it was developed overseas (NT News 7 May 1985).

At present the Aborigines are taking the lead in this regard. Solanum fruits are frequently found at camps where they have colonised the disturbed ground or seeds have been spilt from fruit eaten at camps. We also. noted Ipomoea plants colonising a large area of cleared ground at Yaribilangu. Simílarly we saw a large Ipomoea plant in an outstation garden near Utopia (Kurratjong). Kimber (1976) records a man taking Ipomoea runners and planting them at Papunya and in two other instances records men at Yuendumu planting seeds and cuttings from wild figs and a species of acacia used for making spears. We also saw a large bush plum tree in a garden at Tjunti and Kolatas (Coombs et al. 1983) records a man planting and harvesting a domesticated crop of wild tobacco, and another who planted a northern species of bush tomato at Docker River (pers. comm.). Winfield (1982) records the widespread practice of planting kurrajong seeds at camps and we observed the common practice of transplanting bean trees and red gum trees at camp. All these examples point to the growing recognition by Aboriginal people of the benefits and possibilities of domesticating bush 
crops and thus having bush foods at their finger tips - rather than scattered widely through the bush. It is almost as if the Aborigines are moving into a pre-agricultural state and the question which now needs to be asked is, how can this possibility be given momentum, how much help should be given by Europeans and what techniques can be used to transplant and cultivate wild foods most effectively?

In the past there has been a tradition amongst many Europeans to deride traditional Aboriginal foods and to embarrass Aborigines by refusing food offered or tasting and spitting food out. The following example highlights this:

..Every day Jens was having a busy time, trying to film all aspects of aboriginal life...he had as his subject Leslie, a small aboriginal child, who knew no English but who had appealing eyes, a smile that was seraphic, and the attribute of being almost omnipresent... Jens filmed Leslie eating juicy live witchetty grubs, which the child loved... Jens had some small packets of chewing gum, supplied him by a Danish sweet manufacturer... Jens hit on the idea ...a shot of the boy being given some chewing gum which,...he was to unwrap and eat, throwing away the feast of his non-appetizing grubs. The last close up was to show Leslie's beatific smile at the pleasure of the gum's flavour (Dean and Carell $1955: 136)$.

The effect of the ignorant distaste Europeans have for Aboriginal food has reflected itself within the Aboriginal community - particularly amongst the young - who perceive European fruits and vegetables as in some way better than their own. We observed examples where colonies of Solanum fruits and Ipomoea tubers will be cleared way in favour of having 'neat' camps and for planting orchards of citrus fruits and vegetable gardens. Europeans, and to a certain extent younger generations of Aborigines need to be re-educated to the value of important bush foods. As outlined above they are nutritious, abundant, easy to gather and do not require continual maintenance to survive.

Given the advantage of bush crops it seems logical to select the best of these crops for experimental cultivation at outstations. Consideration when selecting these crops should be given to providing seasonal diversity in the availability of fruits and tubers and the climatic and environmental variations between homeland regions. Crops which would seem eminently suitable are listed in Table 8.10 .

In advocating the domestication of bush fruits, tubers and seeds we are tempted to strike a mutual cultural chord: capitalising on the principle benefits of European domestication and catering for the cultural preference of the Aboriginal people. Advantages of the bush crops are obvious. They are nutritious and are adapted to the difficult desert environment. They do not require constant upkeep - people can move away for extended periods following deaths or during ceremonies, and the crop will still grow. There are not the same needs for equipment - such as extensive reticulation, water tanks and windmills and thus breakdowns do not result in the loss of crops. Bush crops are resistant to pests such as cabbage and hawk moth, eel worm, fruit fly and birds - although pests like rabbits will still present something of a problem. 
The principles of incorporation of natural resources into the outstation environment - particularly as part of an integrated system of European horticulture have been described by Mollison (1984) in his book on permaculture. Although we consider some of the ideas unsuited to the Aboriginal way of life (e.g. gold fish in water tanks and dams (p63), underground waterholes for quails (p68), dove cotes (p76)) and note that some of his models have ceased to function (Ulumparra, Kaapa City, Ernabella Nursery, Warren (reek) we consider many of his basic ideas and principles sound. We would recommend therefore that organisations such as Mollison's permaculture society and other organisations currently on the verge of investigating the viability of bush crops (Pitjantjatjara Land Council, CSIRO, Conservation Commission of the Northern Territory) be given financial support to pursue this line of investigation.

In conclusion therefore, we consider that enriching outstation environments with easy care, popular bush resources is a viable and practical option in the development of arid land outstations. This, in conjunction with the sensible location of camps in resource rich areas and by increasing access to the local foraging environment are practical means of improving the economic and nutritional status of people living at outstations. We would imagine that the planning and development of such options may take five to 10 years - but are necessary for the long term viability of desert camps. We should state however that at this stage we see these options as supplementary. We cannot foresee a situation where desert outstations will be entirely self sufficient, economically independent residental units.

European Land Use

Prehistoric background to cultivation

Before discussing contemporary Aboriginal involvement in agriculture it may be worth looking briefly at the prehistoric involvement of Aborigines in agricultural practices. The question is often asked why the Aborigines remained nomadic hunter gatherers while so much of the rest of the world developed intensified agricultural methods to meet their economic needs (Allen 1974; Peterson 1976; Mulvaney 1975; Flood 1982). Was there for example some environmental constraint preventing the Aborigines from becoming farmers and gardeners? Were the Aborigines too stupid to think of it, or were they too isolated to have come across the idea? Were they too lazy or were their cultural traditions too conservative to adapt to the changes taking place in the rest of the world? Although these questions have been asked this problem is now seen as largely ethnocentric - evolving from the presumption of the value of hard work on behalf of Europeans.

...black men, we wish to make you happy. But you cannot be happy unless you imitate white men. Build huts, wear clothes, work and be useful (Governor Gawler, South Australia 1838 in Mulvaney 1975:238).

Subsequent research has revealed that none of these reasons - environment, conservatism, lack of inventiveness, laziness, were likely to have accounted for the absence of agricultural enterprises. Rather it appears the Aborigines avoided such responsibilities because they saw no economic need to accept them; that the Aborigines did not become peasants because they wished to avoid its drudgery. The Aborigines were definitely not loathe to change and appear to have been quick to accept changes they 
perceived as advantageous. The most obvious was the acceptance and domestication of the dingo some 4,000 years ago (Kimber 1976) and the European dog in the 18 th century in Tasmania (Jones 1970). Aborigines had ample contact with agricultural people. Agriculture was being practised in the New Guinea Highlands 9,000 years ago and the pig had probably been domesticated 10,000 years ago (Flood 1983). At that time New Guinea was part of the Australian mainland - in fact the New Guinea natives were really Australian Aborigines until 5,000-6,000 years ago (Chappell and Thom 1977). Yet none of these agricultural developments were adopted by the Aborigines. Aborigines have also had substantial contact with Indonesia over the last 1,000 years (Macknight 1972) and most likely had contact with Chinese, Polynesians and Arabs as well (Mulvaney 1975). Macassan fishermen (from Sulawesi) hunted trepang (sea slugs) in Australia's tropical waters seasonally. When Flinders circumnavigated Australia in 1803 he was stunned to find more than 1,000 Indonesians working the Arnhem Land coastline. From these fishermen the Aborigines learned Indonesian words for place names and personal names, they adopted songs and myths and aspects of technology and material culture such as iron, sails, dugout canoes, detachable harpoon heads and cloth. Smoking was adopted as was alcohol. In 1876 there were said to be at least 17 Aborigines living in Macassar (Macknight 1972; Peterson 1976; Mulvaney 1975). Aborigines readily accepted cultural changes from these people - but accepted nothing which changed their subsistence base. They did not begin trepanging, use pottery or take up horticulture. The most common accepted reason for this was that there was no economic motive for doing so. The subsistence economy maintained by Aborigines was fairly leisurely (who would trade a few hours hunting and gathering for eight hours labouring in a paddy field?) and allowed ample time for religion, artistic and social pursuits - more than all but a few western composers and artists can afford today. Further, the common property rules, which spread the rewards from the efforts of one person amongst many people, greatly reduce the incentive for production and trade. In the desert the reasons were even more fundamental. Here there was simply not enough water to support a sedentary agricultural population. The nomadic existence was the most efficient subsistence strategy for this environment. Even today, with modern technological and agricultural facilities, Europeans have not been able to settle the core desert region of Australia.

Furthermore the sharing and reciprocating necessary for survival and co-existence in the desert were not conducive to the success of individual agricultural endeavours. Among the Kalahari (!Kung) bushmen for example (a group who have close cultural and environmental parallels with western Desert Aborigines) Lee points out:

There are real contradictions between the organization and ideology of farming and the organization and ideology of foraging. The most important of these is the contradiction between sharing, or generalized reciprocity, which is central to the hunting and gathering way of life, and the saving, or husbandry of resources, which is equally central to the farming and herding way of life. The food of the !Kung camp is shared out immediately with residents and visitors alike; for herders to do the same with their livestock, or farmers with their harvested grain, would quickly put them out of business (1979:142).

Given such lack of economic necessity and the rigour of the Australian desert environment it is really no surprise that European-inspired 
horticultural developments at outstations have met with almost universal failure. What is surprising however is the ignorance and impatience with which Europeans have expected all desert Aboriginal people to jump successfully into intensified agriculture over a period, which to Aborigines, amounts to no more than a chronological snap of the fingers.

European Land Use Overview

Taking an overview of the land use practices recorded at the outstations visited it is apparent that the greatest proportion (68 per cent) of camps employ either minor or no European land use practices at all (Table 8.11). Specifically there are 36 per cent camps with no European land use practices and 32 per cent using minor land management strategies. Another 24 per cent are using European land use methods to a moderate degree but only 7.5 per cent have developed these techniques to any major extent. We should stress that each of these categories are quite relative defined only in terms of contemporary outstation development. For example, what appears to be a 'moderate' degree of European land use within the homelands context would seem quite insignificant to an Alice springs commercial market gardener. We use the term comparatively, as a relative guide to assess the current outstation situation. When describing land use practices as 'minor' (e.g. at Emu Bore, Mt. Theo, Inyillingki) we envisage a camp with a few fruit trees, vegetables or shade trees planted and/or a little animal husbandry (e.g. a chook run). When using the term 'moderate' we are referring to camps with several fruit, vegetable and shade trees planted, and a moderately large (approx. $25 \mathrm{~m} \mathrm{x} 25 \mathrm{~m}$ ) garden and/or rather more established animal husbandry (goats, chickens, horses) (e.g. David Well, Wakalpa, Puntitjarta). The term 'major' refers to camps with large gardens, extensive camp improvements and/or involvement in animal husbandry (e.g. Katjkatjitjara, Tjatja, Ngaligalangu, Black Hill).

Table 8.1:1

European land use practices at desert outstations

\begin{tabular}{lccccc} 
Homelands & Major & Moderate & Minor & None & Total \\
\hline Pintupi & - & - & - & 6 & 6 \\
Luritja & - & 1 & 7 & 4 & 12 \\
Walpiri & 1 & 4 & 4 & 4 & 13 \\
$\begin{array}{l}\text { Pitjantjatjara/ } \\
\quad \text { Ngaanyatjara }\end{array}$ & - & 4 & 6 & 3 & 13 \\
$\begin{array}{l}\text { Pitjantjatjara/ } \\
\text { Yangkuntjatjara }\end{array}$ & 3 & 4 & - & 2 & 9 \\
\cline { 2 - 6 } & & $13(24.58)$ & $17(328)$ & $9(368)$ & 53
\end{tabular}

Looking at each region individually it is apparent that there is virtually no European land use in the Pintupi Homelands, very little in the 
Luritja Homelands, notably more in the Walpiri and Pitjantjatjara/ Ngaanyatjara Homelands and more in Pitjantjatjara/Yangkuntjatjara Homelands around Ernabella. In fact the extent to which different linguistic groups have adopted European land use methods is almost inversely proportional to the amount of traditional land use employed by each group. At either end of this scale are camps around Kintore and those around Ernabella. In the former traditional land use is strong and European land use is nonexistent. In the latter traditional land use is relatively minor and European land use is quite strong. The camps in other areas fall somewhere in between, with decreasing traditional land use strategies and increasing European land use strategies in the Luritja, Walpiri and Pitjantjatjara/ Ngaanyatjara linguistic areas respectively. There seem to be several reasons for this. One of the overriding factors seems to be the duration and consistency of European and Aboriginal contact. The pattern which emerges from our investigation is that the Aborigines, with the longest consistent contact with 'decent' Europeans, have adopted European ways extensively and successfully. The Pitjantjatjara and Yangkuntjatjara at Ernabella for example have a long history of compassionate European contact and are clearly the most sophisticated people we worked with. The Pintupi on the other hand have had a short, unpleasant contact history and this has manifested itself in their fundamental rejection of Europeans and their values. Given another 30 years of contact however, the situation may be rather different and Pintupi developments may more closely resemble those of Ernabella today. We consider that time is the important underlying factor effecting the nature of economic, social and cultural change amongst Western Desert people. Desert people have had to make an enormous jump from nomadic hunter gatherers to 20 th century Australians. So far the changes already made by the Aborigines have been quite dramatic, but obviously more time is needed for these changes to be made comfortably and successfully.

\section{Outstation Horticulture}

With the exception of the gardening enterprise in the Pitjantjatjara/ Yangkuntjatjara Homelands and at a few camps near Docker River Europeaninspired gardening projects at most of the outstations we visited have been largely unsuccessful. There were various personal, cultural and environmental reasons for this and these are worth summarizing here. One of the most obvious factors inhibiting the development of outstation gardens was the general disinterest shown by the Aborigines in the projects. Gardening as an economic activity on outstations is not really compatible with the traditional Aboriginal life style, the high mobility of the people, the numerous visits away from camps to friends and relatives, extended involvement in ceremonial activity and the complete abandonment of camps for several years following deaths.

Given these cultural characteristics the plans and expectations of the original gardening projects in the early 1970 s reflect an extraordinary ignorance by Europeans of Aboriginal culture. Had the Europeans had a better understanding of Aboriginal people it is probable the gardening projects like those begun in the Luritja Homelands may never have been so ambitious. Highlighting this lack of cultural awareness is the fact that Europeans chose and trained Aboriginal men as gardeners. This is in marked contrast to the traditional sexual division of labour. In the past women were the gatherers of vegetable foods - while the men were the ceremonial spokesmen and hunters. In' those days women were the economic backbone of desert. Aboriginal society and, as today, were left at camps with the economic responsibilities of the household while the men immersed themselves in ceremonial business. Given this tradition it would have seemed 
more logical (and probably more effective) to have selected and trained women as gardeners and to have employed female horticultural advisers in the past. We would strongly recommend this if horticultural activities are to continue at outstations in the future.

In addition to these problems are major environmental difficulties. The most obvious environmental difficulties are lack of water, poor water quality, shallow infertile soil, high evaporation rates, strong winds, hot summers, freezing winters, droughts, floods, rabbits, birds, termite and other. insect pests. Successfully gardening under normal conditions is hard, regular work but in the desert these problems make even the most routine gardening activities almost impossible.

These factors, coupled with an almost complete lack of experience and expertise amongst Aboriginal people, makes the prospects for successful horticultural development at outstations very limited. Currently vegetable plots are not thinned out, there is no mulch, no shade or shelter, plants are under-watered as well as over-watered. Furthermore many of the crops planted (spinach, peas, beans, grapefruit, zucchini) are unpopular and unfamiliar to the Aborigines. Gardens also run the continual risk of being vandalised by children.

Given all these complications one wonders why gardens were started at all and this leads one to ask what the responsible personnel were hoping to achieve by promoting horticultural activities at outstations. Was it simply that they wished to give the Aborigines something to do? Did they feel they were providing the opportunity for the Aborgines to enter the economic market place - growing and exporting vegetables to neighbouring town centres? Did they hope that the introduction of European vegetables would improve the nutritional status of outstation dwellers? We suspect all three factors provided motivation for European involvement, but we question the justification of these motives. For. example, we suspect that Europeans' sense of cultural propriety is often of fended when they see Aborigines sitting around talking - 'doing nothing'. If so we might ask ourselves what right Europeans have to enforce their protestant work ethic on the Aboriginal life style. Furthermore how feasible, really, is the export potential of outstation fruit and vegetables? What nutritional contribution can European fruit and vegetables make that the Aborgines cannot get from the bush environment? What we would like to know is what Europeans really thought they were contributing to the Aboriginal people with their horticultural ideas and how compatible was this with the Aborigines' own aspirations.

There are, of course, many instances of the Aborigines 'wanting a garden', but if our understanding of the situation is correct, these requests are largely political (see also Peterson 1976). It was our impression in most instances (and again Ernabella is something of an exception) that Aborigines were either doing as they had been told or were using the idea of a garden to impress Europeans and thus ensure effective funding, lure the provision of a windmill, demonstrate to Europeans that they are 'committed' to their camps. The evidence suggests to us that the Aborigines see no other benefit in establishing gardens and thus have no real interest in gardening or any other agricultural enterprise. Kimber (1983: 179), lists 14 agricultural ventures which have been unsuccessful in the Papunya region alone (vegetable garden, piggery, citrus orchard, carob tree orchard, olive tree orchard, rose gardens, other flower gardens, goat husbandry, re-afforestation, date palms, bee keeping, lucerne crops, poultry and camel domestication). Thus, it is painfully obvious that the 
land use projects motivated by Europeans have been enterprising - but very unsuccessful. It is clear that government departments need to do some hard thinking about what they are trying to achieve, how they are going about it and how their plan corresponds with the Aborigines' own ideas for the future.

It is our opinion that European horticulture does have some advantages to Aborigines living on outstations. Aboriginal people do, after all, like to eat some European fruits and gardens have the potential to improve the value of the local environment. The outstations near Ernabella and Hermannsburg and a few of the camps near Yuendumu and Docker River are testimony to this. The question which needs to be addressed is how can horticultural development be made more effective and more appealing to Aborigines.

It is our opinion given the environmental and cultural difficulties outlined above, that horticultural development at this stage should be small and basic at most camps. The crops need to be hardy - requiring minimal maintenance and be popular with Aborgines. They also need to have been proven successfully elsewhere in Central Australia. Suitable crops would thus appear to be mulberries, oranges, dates, pumpkins, rockmelons, grapes and figs. Other authors have suggested a greater variety of crops (Maggs 1978, Mollison 1984) which may be suitable at arid outstations - but our feeling is that the number should be kept low - restricted to 'tried and true' varieties. Initially garden plots should be small ( $5 \mathrm{~m} \times 5 \mathrm{~m})$, planted in strategic locations such as in the shade of houses and sheds, adjacent to taps, water tanks, windmills and hand pumps, near rock seepages, old soaks areas, near natural or harvested runoff, along river beds and in old stock yards where the soil is more fertile. Mollison (1984, 1978) outlines a wealth of suitable cultivation techniques which may be sucessful if developed on a small scale. Also, as indicated above we suggest that it may be wiser to educate women in horticultural skills and employ female horticultural advisers to assist them.

Thus the general theme we recommend is to start with a few hardy, popular crops from which the Aborgines can get a physical result and in doing so they learn the basic principles and benefits of horticultural activities. From these smaller gardens, larger gardens may well develop of their own accord. Obviously it is better to start small, learning the necessary skills and developing more diverse gardens as skills are acquired than to start big, without the managerial or technical skills required and have the gardens fail.

It was our impression that in some areas the Aborigines are trying their own hand at establishing small manageable plots of hardy, tasty fruits and vegetables. It seemed to us that these incipient gardens reflect an attempt by Aborigines to capitalise on European horticulture, within the confines of the outstation environment and lifestyle. Humble attempts of this kind were recorded at some Luritja camps (Alkipi; Inyilingki, New Bore) and to a more successful degree in the walpiri Homelands (Wayililinypa, Wakalpa, Yaribiilangu, Nyirrpi). As yet these gardens have little productive potential but do have an important educational value. Most importantly they are Aboriginal-inspired, are manageable and generally appear to be surviving. These gardens may well sow the seeds for more extensive horticultural success in the long term. However, the Aborigines in these regions are still very inexperienced and are in need of advice from a horticultural expert. 
We would envisage that such advice be organised along the lines of a team of regional horticultural advisers servicing specific areas such as the Pintupi, Luritja and Walpiri Homelands or alternatively the Yangkuntjatjara, Pitjantjatjara, Ngaanyatjara Homelands. Individual advisers would need to make regular (monthly) visits to camps interested in gardens (and we should stress here that not all Aborgines are green fingered and will want gardens) to give advice, provide practical assistance and deliver fruit and vegetable seedlings. It is important, however, that such advisers have patience, advise the Aborigines carefully and work at a pace conducive to the Aborigines. It is important that such advisers do not enthusiastically develop Aboriginal attempts, take over and direct the horticultural developments at camps. We envisaged such a task would only produce small results over a long period of time (10-15 years) but see it nevertheless as an essential step in the process of horticultural development which the Aborigines and government bodies will have to go through if horticulture is ever to become a viable part of the outstation economy. If, in this way, the Aborigines can be introduced to the techniques and benefits of horticulture and, if European crops are planted in camp alongside an intensified range of bush species (as advocated in the preceding section) there seems to be real potential for increasing the amount of food grown at outstations for local consumption, improving the nutritional status of outstation occupants and generally improving the value and productivity of the outstation environment.

There are some camps however which do not require such fundamental beginnings and at which horticultural techniques are already being employed with some obvious success. Such camps include Puta Puta, Tjunti and Puntitjarta near Docker River and most of the camps with gardens near Ernabella. There are several obvious reasons for this. One of these is that the Aborigines at these camps have a genuine interest in their gardens and consequently retain the desire to maintain them. Also the Aborigines, particularly around Ernabella, have had long constant contact with agricultural advisers and thus have now learnt some of the skills necessary for successful horticulture. Thirdly, Aborigines in both regions have had access to professional advice. In the case of Ernabella they had 10 years of teaching from a professional agronomist (M. Last) and at Docker River, three years of advice from a botanist horticulturalist (A. Kolatas). The experience and expertise of both men are invaluable and, particularly given the unique success of the Ernabella experience, are worth documenting for future advisers along with guidelines and other suggestion for working with Aborigines, crop selection and effective planting methods.

Animal Husbandry

Various camps in the homelands visited have, or have had, some involvement in animal husbandry, such as domesticated goats, cattle, chickens, horses, sheep and camels. However, with the exception of Black Hill, which runs cattle belonging to Ernabella at a profit most of the camps we visited appeared to be doing this without any sort of profit tangible result. The only other camp involved in any major cattle work was Ngalijalangu, and although we could not obtain specific data about this operation our impression was that this enterprise was not healthy. The profitability of the cattle industry generally in the Northern Territory appears doubtful. It is an industry that requires high capital investment, specific management skills and is faced with rising costs of labour and transportation. It can only return a modest living for a small number of people and difficulties are currently magnified by the costs of meeting the Federal Government Tuberculosis and Brucelosis Eradication Campaign. 
Furthermore some of the country on which outstations are situated has already been heavily grazed and is in need of time to regenerate (particularly near Yuendumu and Papunya - but see also Shaw 1983 for Utopia). Some camps are also located on spinifex sandplains and these have no value for stock at all. Thus camps such as Tjila Well, Kungkayunti and Wayililinypa which talk of running cattle really have no chance of doing so successfully near their camps. Some of the alluvial plains around Docker River and Ernabella present good cattle country. They are vegetated by grasses, herbaceous vegetables and edible shrubs and could support up to five head of cattle per sq km (Perry 1960). However we would recommend against this as such development would require high capital investment with no guarantees the operation would be successful (see Shaw 1984). Furthermore such cattle industries would require increased involvement by Europeans in outstation organisations (transport, maintenance, inspection, marketing of cattle) and this is inconsistent, at this stage, with the Aborigines' goals of independence and self determination. Also cattle present a severe environment threat (see Frith 1978), particularly in regions where rabbits are abundant. Cattle destroy the bush and foul waterholes and are in direct competition with the native population of macropods. This was highlighted around Ernabella and Docker River where much of the country is in good condition. Here the numbers of kangaroo were relatively high. Conversely, at Mt. Singleton (Yuendumu), which was once good kangaroo country, there are large numbers of cattle but not many kangaroo. Thus in the long term it may be wiser for Aboriginal people to avoid the cattle business and stick to hunting kangaroo. Small 'killer' herds, however may be a viable option for outstations in the more fertile regions. They have the potential to provide a source of protein and require fewer management skills and have minimal ecological impact.

Sheep may also be a viable option for camps located in fertile country. One camp (Wintuwintutjara) has fenced of $f$ a large area around their camp and intend running sheep. In the past sheep were an integral part of Aboriginal life around Ernabella. Women wove wool using traditional techniques and made large woollen rugs to sell. The wool could also be used for clothing and the animals were used for meat. Sheep appear to have been an acceptable industry among Aborigines in the past as they fitted in with their traditional way of 1 ife - allowing the Aborigines to move about the countryside shepherding sheep from one waterhole to another (Last 1978). Thus the potential of sheep flocks at outstations in more fertile areas may well be worth investigation for the future.

Goats on the other hand do not appear to have been very successful at any outstations. There were apparently some in the mountainous country near Wakalpa but others let loose at camps on the sandplains had just walked away. Angora goats had been tried at Black water but failed. There are some goats at Docker River but these are unpopular with the Aborigines because they do so much damage. Goats have the potential to provide a source of meat and.milk at outstations near mountains but we would advise against the domestication of goats given the potential environmental threat they pose - and the competition they present to euros and rock wallabies, which are important traditional sources of meat.

Some of the Walpiri camps (Yumurrpa, Yarribiilangu, Wakalpa) and one Yankuntjarra camp (Katjikatjitjara) had established small chook runs. This is an interesting aspect. of outstation development as it has the potential to provide a regular supply of protein to outstation occupants. At the Walpiri camps however the chooks and eggs are rarely eaten, children smash the eggs and dingoes and feral cats eat the chooks. Nevertheless chooks are 
popular and with a little advice and better coops, feeding and watering methods, they have the potential for becoming a useful component of local outstation economies.

\section{Camp Improvements}

With the exception of camps in the Pintupi Homelands, most camps made some attempts to improve the appearance of their camps. Sometimes these attempts were relatively minor - consisting of the planting of a few red gums and bean trees (Emu Bore, Yumurrpa) or more extensive rows of exotic trees, bamboo and cane grass (Tja Tja, Katjikatjitjara). These plants provide shelter, shade and improve the appearance of camps. One of the bizarre aspects of this particular process however, is that when camps are set up the local vegetation is usually savaged - trees are cut down for windbreaks, children ring bark trees, shrubs are cleared and the surrounding area burnt. Clearly Aborigines view camp aesthetics differently from Europeans and do not necessarily see the benefits of improving the visual and environmental quality of their camps. Nevertheless given the likely long term sedentary nature of Aboriginal settlement we suggest policies of re-afforestation, camp beautification and dust control, and that education towards these goals be continued.

\section{Mining}

No camps we visited were involved in any mining activities - apart from the collection of natural ochre for ceremonial activities. Minerals and gems are found in the vicinity of some outstations (chrysoprase, copper, gold, tungsten) but none of these are mined for economic return by the Aborigines. To be profitable small. scale mining ventures at outstations would have to mine very valuable ores. Tungsten and gold thus present the most viable option if Aborigines choose to pursue this line of endeavour in the future. Chrysoprase has been mined at Pipalyatjara with some success (Coombs 1978b:29) but this has remaind a relative small operation (Griffin and Lendon 1979).

Large scale European mining is also a potential source of income. Currently there are no mining operations in the regions we visitd but there are plans to mine gold near Bloods Range in the Pitjantjatjara/Ngaanyatjara Homelands and at the Granites in the Walpiri Homelands. There is also interest in natural gas and oil in the desert region. It was our impression that the Aborgines have no major objections to this kind of development if sites of significance are not disturbed and they receive adequate payment. The impact of these developments on the Aborigines and their effect on the outstation movement will require careful monitoring. The Aborigines will also need to be regularly consulted and advised as to the long term implications of such development.

\section{Tourism}

Tourism has perhaps the greatest economic potential for Aborigines in remote communities and outstations. Currently movement of tourists through Aboriginal land is rather uncontrolled - people drive virtually where they like, are very free with their cameras and have been recorded damaging and stealing sacred objects (Latz 1983). For these reasons Aborigines discourage tourism and get quite annoyed when tourists travel unannounced through Aboriginal country. 
The type of tourists visiting Aboriginal land vary from region to region. There are more 'conventional' tourists around Ayers Rock, more adventure package tourists on the Tanami Track and more outback adventurers on the Gun Barrell Highway and crossing the Central Australia in pintupi country. Objections by Aborgines are usually channelled through Community Advisers or Land Councils. Thus attempts to stop tourist movements are rather indirect and largely ineffective. The Aborigines themselves are superficially polite and sociable to tourists and rarely challenge them directly.

It is our opinion that tourists are going to continue to travel through Aboriginal land, and increase rather than decrease in number. Thus it may be that the only way the Aborigines can control the movement of Europeans through their land may be to take part in it; thus exercise direct control over access, number and areas visited rather than stand aside impassively. Direct involvement in the industry would also provide direct and indirect employment for Aborigines - as guides, rangers and education officers teaching tourists about Aboriginal traditions, subsistence strategies, religion and bush flora and fauna. There is no point employing Aborigines solely as cleaners, groundsmen and parking attendants as is the case in other parks in the Northern Territory. The exact nature of employment would depend on the nature of the particular development Aborigines chose to support. These could vary from high paying groups taken on 'adventures' through traditional country or the Aborigines may simply wish to sell artefacts to passers by and through outlets at major tourist centres. Another alternative may be to cater for the growing number of bush walkers in Australia in search of the wilderness experience. The desert landscape is certainly beautiful and wild enough to attract large numbers of hikers. The Aborigines could capitalize on this; modelling the development on the trekking methods used in Nepal. Here treks are either led by local people - or hikers walk along predetermined trails, from village to village where they stop each night paying for basic shelter, food and refreshment. If organised properly such an operation could have substantial, reliable, economic benefits to outstation groups with little unwanted inconvenience or impact on Aboriginal culture. suitable areas for this $k$ ind of development may be where there are clusters of camps in close proximity to beautiful country (for example east and south of Docker River, around Ernabella, near Mt. Liebig). Winter would probably see the greatest influx of hikers.

At present the Aborigines are against tourism but over the next 10 years or so they may be wiser to become involved in the direction and development of local aspects of the industry than offering passive resistence to developments that may take place anyway. 


\section{Concluding Recommendations}

This chapter lists the main recommendations included in this report. To provide justification and comment on these recommendations, the chapter (c) and page number (p) where the issue is discussed in the text are indicated thus $(c ; p)$.

\section{Resources}

1. Substantial economic growth has taken place in central Australia and is likely to continue to take place in the areas of tourism and, to a lesser extent, mining and tourism support industries. However, outstation people generally are unlikely to benefit from these developments in terms of incomes and employment unless the developments take place on Aboriginal land. There are social costs of this, of course $(2 ; 9,11)$.

2. Changes in the structure of the cattle industry, which have been induced by the BTEC program, have greatly reduced the usefulness of large-scale cattle enterprises for Aborigines. However, cattle activities, in the form of small killer herds, could be very useful in providing sources of protein, provide training in stock work, and they could reduce environmental pressures arising from traditional land use practices. Small killer herds would not cause the widespread environmental damage and other problems which result from large-scale cattle operations. Sheep could also be held in small flocks, to provide meat and wool $(2 ; 11)$.

3. The fundamental economic circumstances of people living on outstations are such that their employment prospects are bleak. For most people, cash incomes will be largely made up of DSS incomes, supplemented with incomes from occasional employment and artefact making. Bush tucker is, and will remain, an important way of supplementing these very low cash incomes. Because cash incomes will remain low, funds for social overhead capital will have to continue to come from government sources $(2 ; 19)$.

4. Funds allocated to outstation support have come from a wide range of government bodies with different philosophies and allocation criteria. These philosophies and criteria need to be re-thought and more coordination between departments dealing with outstations is needed $(2 ; 30)$.

5. Because the resources which outstation people receive are, and will remain few it is important that their allocation conform as closely as possible to Aboriginal tastes. The CDEP scheme and the tentative attempts at block funding which are being made by DAA are steps in the right direction. Greater changes need to be made towards allowing the appropriate Aboriginal organisations to allocate funds. The CDEP scheme, particularly, needs to be encouraged, with some modifications. wages received under the scheme, for instance, should be supplemented to reflect skills which some workers possess. The government should fund these supplements $(2 ; 31)$. 
6. The movement to outstations has meant that many young people have less access to educational and training facilities. If our expectations for 1 ifestyles and employment prospects are correct then there is a need to re-think the nature and roles of training and education to aid people to live in their new environments $(2 ; 31)$. Schools in the outstations are very poorly equipped and there is the need to channel more resources into them and 'School of the Air' programs should be produced for the children in outstations $(8 ; 178)$.

7. Overall, DAA profiles are reasonably accurate in terms of their descriptions of housing, radios, vehicles, water equipment and schooling. However, their estimates of population were greater than we found at outstations, and some outstations were not recorded in DAA profiles at all $(8 ; 157)$.

8. Radio and water equipment were often missing or did not work or required maintenance. The fact that people may be absent from their outstations for a long time (perhaps two years if someone has died) makes routine maintenance difficult and stresses the need for the installation of low maintenance equipment. Maintenance personnel ought to be employed by outstation organisations and other representative bodies for the purpose of maintaining the equipment $(8 ; 170,177)$.

9. The outstation movement seemed to be a success in the sense that, with the exception of the Docker River outstations, the great majority of outstations appeared to be in use. The occupants are often away from the outstations for substantial periods of time however, to attend 'business', sporting, social or political events and to go hunting. They often travelled great distances for these purposes $(8 ; 159)$.

10. It is very likely that the pintupi people will continue to move further west and north. This will raise a number of intergovernmental and resource issues. The Western Australian, Northern Territory and Commonwealth governments will be involved in this move and coordination of their policies will be needed. The likelihood of this movement also has implications for the ways in which resources should be allocated to the Kintore outstations. We would like to see overt attempts being made by relevant government departments to discover where the Pintupi, who were originally from the west and north-west of Kintore, would like to settle and to provide facilities to assist them in their move. The sooner this is done, the better, otherwise resources may be allocated to projects around Kintore which are of no long-term use $(8 ; 160)$.

11. The average age of people living on outstations is much greater than for the Aboriginal population overall. Lack of schools is an important reason for this. The age of the population, however, has important implications for the stability of outstations. Over the next 10-15 years many old people will die and people may have to leave the outstations to which they belonged for a period of two years. This movement should not be interpreted as abandonment of outstations however $(8 ; 163)$.

12. In many cases there was a lack of coordination between departments supplying water and housing: some outstations had houses but no water, while others had water but not houses. Attempts are needed to coordinate the provision of these facilities $(8 ; 168)$. In particular, a suitable water supply needs to be found before an outstation is 
developed. Overall, first stage houses were successful and were liked: they provided shelter from the rain and wind, protection for possessions and privacy. The hexagonal shelters at Docker River, however, were more costly and were not nearly as successful. There needs to be much more Aboriginal employment in the construction of houses. This could have a substantial training effect and assist people in learning house maintenance $(8 ; 168)$. More Aboriginal involvement is needed in the provision of water equipment and in the development of the outstations generally.

13. Subterranean water, generally, was of very poor quality. This has a number of policy implications. Firstly, the peoples' health should be monitored in an attempt to detect any health problems. Secondly, they should be instructed on the health dangers associated with consuming water of poor quality. Thirdly, where the problem is serious, tracks should be made to allow people to gain access to major surface water supplies. Finally, research into cheap water purification processes should be encouraged $(8 ; 173)$.

14. The government needs to monitor the homelands movement carefully, identifying patterns in the development and to gather reliable data so it can facilitate the smooth and cost effective growth of the movement in the future. As part of this monitoring process, field officers need to spend longer, regular periods in the bush. Ideally these officers would be Aboriginal people or officers with anthropological training. $(8 ; 162,171)$.

15. As the homeland movement expands, minor resource centres will become more numerous and distant. This may necessitate a co-ordinating resource supplier delivering goods and services to these centres $(8 ; 180)$.

16. The ABTA practice of funding of the purchase of vehicles on a 10 per cent contribution by the purchaser should continue. We believe that the need to save their contribution has an important educative effect for Aborigines and limits trivial demands for vehicles $(8 ; 175)$.

17. Generally, the quality of services provided to outstations was adequate, with the exception of education $(8 ; 177)$. There are likely to be demands for improved facilities in the future, however $(8 ; 164)$.

Land Use

18. Certain traditional land use practices continue to be important and traditional food production contributes significantly to Aborigines' incomes. Indeed some practices have grown in importance in recent years with the development of the outstation movement. Fire remains the most important tool of traditional land management and its continued use is necessary to maintain the productivity of the land. Any general attempt to discourage the use of fire will create hardships for people who already have very low incomes. In some areas where fire is causing environmental damage, modification of this practice may be necessary. In general, we believe that cash incomes will remain low in the indefinite future and that bush production will continue to be an important supplement to cash incomes. Seed collection and artefact production for sale are cash spin-offs which accompany continued bush production $(8 ; 196)$. 
19. To capitalise on bush resources it is important to select the location of outstations carefully so they have access to the combined resources of the desert environment. The more fertile desert location could be located using satellite imagery and limited ground traverses. From this a predictive regional land use strategy could be developed to assist government departments and Aborigines alike in choosing locations for outstations $(8 ; 200)$. Currently Aboriginal men are trained as gardeners. This is in marked contrast to the traditional sexual divisions of labour. Consequently women should be trained as gardeners and female horticultural advisers employed $(8 ; 206)$.

20. Damper made from traditional sources is considerably more nutritious than that made from European flour, and the seeds are greatly abundant throughout much of the year. The problem with their use is that the grinding process is very arduous and the use of traditional flour would be encouraged if a simple and effective hand mill could be devised. The appropriate technology unit of the Alice springs Community College, or some similar body, should be encouraged to undertake such a project $(8 ; 188)$.

21. Bush fruit, roots and tubers are highly nutritious and many are easy to collect. These will continue to play an important part in the diets of outstation people. Attempts should be made to encourage the development of informal gardens of these plants $(8 ; 189)$.

22. A system of vehicle tracks should be made to major but inaccessible areas of bush resources. This would aid bush production, improve hygiene, provide access to surface water and relieve pressure on bush resources near the outstations $(8 ; 200)$.

23. In 68 per cent of outstations we visited there was little or no European land use practice evidence. For a range of reasons, normal European farming activities are unlikely to succeed. The approach to horticulture most likely to succeed is small scale and based on permaculture principles. Both the Pitjantjatjara and Docker River outstations employ horticulturalists with considerble experience and knowledge in this area and their experiences need to be documented to aid future horticultural developments. Resources should be made available for this to be done $(8 ; 205)$.

24. Unless a project is motivated and directed by Aboriginal initiatives it is unlikely to succeed; particularly if left to Aborigines to run. It is unwise to establish European style gardens containing European vegetables, requiring European management practices, technology and hardware and then expect unskilled and unenthused Aborigines to maintain it $(6 ; 126)$.

25. Finally we believe that large-scale grazing is inappropriate for areas where outstations have been established. These activities provide little employment, are likely to make a loss on operations, may cause strife amongst outstation people over land use and ownership of cattle and are likely to destroy bush tucker resources. Rather, we believe that the best use of land in the area of study involves the continuation of traditional land use practices, small-scale gardens of traditional and introduced plants, and the keeping of killer herds of cattle and sheep. 
Appendix 1

Names and linguistic area of camps visited

Alkipi
Amputjutu
Araluen Bore
Blackhill
Blackwater
David Well
Desert Bore
Eagle Bore
Emu Bore
Five Mile
Ili Ili
Ilpili
Inyilinki
Itjinpiri
Katjikatjitjara
Karrukali
Kunapula
Kungkayunti
Kutjuntjari
Mitakutjiiri
Mt Liebig
Mt Theo
Muntarti
Muyinnga
New Bore
New Well
Ngaligalangu
Nyirrpi
Petjalu
Pintitjarta
Puta Puta
Puyurru
Tjatja
Tjila Well
Tjinki
Tjukula
Tjulpungu
Tjuninanta
Tjunti
Ulumbarru
Wakalpa
Walka
Wangkari
Warampi
Warren Creek
Warrapura
Wayililinypa
Wintuwintutjara
Yaribiilangu
Yatjulu
Yininti
Yintjirimirri
Yumurrpa
Mutiong

Luritja

Pitjantjatjara/Ngaanyatjara

Pitjantjatjara/Yangkuntjatjara

Luritja

Pitjantjatjara/Yangkuntjatjara

Pintupi

Pitjantjatjara/Yangkuntjatjara

Walpiri

Luritja

$$
\text { " }
$$

Pitjantjatjara/Yangkuntjatjara

Pitjantjatjara/Ngaanyatjara

Luritja

Pitjantjatjara/Ngaanyatjara

Pintupi

Luritja

Walpiri

Pintupi

Luritja

Pitjantjatjara/Yangkuntjatjara Walpiri

Pitjantjatjara/Ngaanyatjara

walpiri

Pitjantjatjara/Yangkuntjatjara

walpiri

Pit jantjatjara/Ngaanyatjara

Walpiri

Pitjantjatjara/Ngaanyatjara

Luritja

Walpiri

Pitjantjatjara/Ngaanyatjara

Luritja

Pitjantjatjara/Ngaanyatjara

Walpiri

Pitjantjatjara/Yangkuntjatjara

Walpiri

Pintupi

walpiri
Papunya

Docker River

Ernabella

Papunya

Ernabella

Kintore

Ernabella

Yuendumu

Papunya

"

$"$

Ernabella

"

Docker River ,

Papunya

Docker River

Kintore

Papunya

Yuendumu

Kintore

"

Papunya

Ernabella

Yuendumu

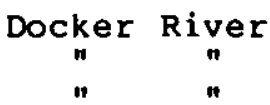

Yuendumu

Ernabella

Yuendumu

Docker River

Yuendumu

Docker River

Papunya

Yuendumu

Docker River

(

Papunya

Docker River

Yuendumu

Ernabella

Yuendumu n

Kintore

Yuendumu 
Appendix 2

\section{Check 1 ist of data recorded in project}

1. Name of camp

2. Location (geographic, nearest settlement, direction, distance)

3. Age of outstation

4. Reason settled (country, mythology, conflict, material benefits)

5. Estate owner (leader)

6. Linguistic area

7. Linguistic, social affiliations of camp occupants

8. Population (pensioners, adults, school children, infants: $m / f$ )

9. Number of family units

10. Mobility (extent of movement - schools, stores, payday, visitors)

11. Accommodation at camp

12. Range travelled: wood, food, water, social contacts (km, direction, location)

13. Topography (landscape, geology, vegetation)

14. Introduced animals (abundance and type)

15. Traditional land use

plants/animals

- species

- number/abundance

- techniques

- economic contribution

actual observations

casual impressions (e.g. economic viability, food preferences, seasonality)

16. Traditional resources available but not used

17. Traditional water used (seasonality)

18. European land use

plants/animals

- species

- number/area cultivated

- economic contribution

- people involved

19. Impact on traditional resources 
Appendix 2, continued.

20. Aboriginal preferences for food types

21. Use of store foods (delivery, kind, extent)

22. Other economic activities (mining, artefacts, stock work)

23. Services and facilities

- water supply (quality, adequacy)

- power

- roads

- airstrip

- vehicles

- stockyards, butchering yards

- fences

- store

- handtools (spade, axe, hammer)

- guns

- skilled labour

- available labour

24. Europeans attached (number, capacity)

25. Local community

- access

- movement between

- mechanical services

- health services

- education services

- food supply

- voting in council

- influence on O.S. enterprises

- supply of O.S. services

26. External income

- U/B cheques

- pensions

- endowment

- enterprises

- bulk payments

- C.D.E.P.

27. Expressed needs (e.g. get cattle, want bore, grade roads, fences, radio) 


\section{Appendix 4}

Addresses of people and organisations referred to in report

Central Australian Aboriginal Congress,

78 Hartley Street, Alice Springs.

Phone: 523377

Central Australian Aboriginal Media Association,

Radio Station, Gap.

Phone: 523744

Central Land Council,

75 Hartley Street, Alice Springs.

Phone: 523800

Commonwealth Scientific and Industrial Research Organization, Heath Road, Alice Springs.

Phone: 524255

Conservation Commission of the Northern Territory, Gap Road, Alice Springs.

Phone: 508211

Department of Aboriginal Affairs,

Cnr Bath and Gregory Streets, Alice springs.

Phone: 504211

Department of Community Development,

Government Centre, Parsons Street, Alice springs.

Phone: 503611

Department of Education,

Gregory Terrace, Alice Springs.

Phone: 504211

Department of Primary Production,

33 Stuart Highway, Alice Springs.

Phone: 503777

Department of Transport and Works (Water Division), Browns Building, Stuart Highway, Alice Springs. Phone: 503327.

Horner, R., (seed supplier),

1 Grundy Street, Alice Springs.

Institute for Aboriginal Development, 3 South Terrace, Alice Springs. Phone: 522688

Kolatas, A.,

C/- Docker River Community,

PMB by Alice Springs 5751 .

Last, M. ,

C/- Pitjantjatjara Land Council

37 Bath Street, Alice Springs.

Phone: 523655 
Appendix 4, continued.

Latz, P.K. ,

C/- Conservation Commission of the Northern Territory, Gap Road, Alice Springs.

Phone: 522344

Low, W.A.,

Ecological Services,

Isotoma Road, Alice Springs.

Phone: 524047

North Australia Research Unit,

PO Box 41321, Casuarina, NT 5792

Phone: 275688

Mollison, B.,

C/- Permaculture Consultancies

PO Box 96, Stanley, Tasmania.

Phone: 7331

Permaculture Consultancies,

Po Box 96, Stanley, Tasmania.

Phone: 7331

Pitjantjatjara Land Council,

37 Bath Street, Alice Springs.

Phone: 523655

School of the Air,

Department of Education,

Gregory Terrace, Alice Springs.

Phone: 522122 


\section{References}

\section{Abbreviations}

$\begin{array}{ll}\text { AGPS } & \text { Australian Government Publishing Service } \\ \text { AIAS } & \text { Australian Institute of Aboriginal Studies } \\ \text { ANU } & \text { Australian National University } \\ \text { ANZAAS } & \text { Australian and New Zealand Association for the } \\ \text { Advancement of Science } & \\ \text { CAAC } & \text { Central Australian Aboriginal Congress } \\ \text { CLC } & \text { Central Land Council } \\ \text { CRES } & \text { Centre for Resource and Environmental Studies } \\ \text { CSIRO } & \text { Commonwealth Scientific and Industrial Research Organisation } \\ \text { DAA } & \text { Department of Aboriginal Affairs (Commonwealth Government) } \\ \text { DCD } & \text { Department of Community Development (Northern Territory } \\ \text { NARU } & \text { Government) } \\ & \text { North Australia Research Unit }\end{array}$

Allen, H., 1979. The Bagundji of the Darling Basin: Cereal Gatherers in an Uncertain Environment. World Archaeology, 39(5) 610-16.

Altman, J., 1983. Aborigines and Mining Royalties in the Northern Territory, AIAS, Canberra.

Altman, J., 1984. Hunter-Gatherer Subsistence Production in Arnhem Land: The Original Affluence Hypothesis re-examined, Mankind 14(3) 179-90.

Arts Research, Training and Support Ltd, June 1981. Improving Focus and Efficiency in the Marketing of Aboriginal Artefacts, report prepared For the Australia Council and Aboriginal Arts and crafts pty Ltd, Sydney.

Asch,M., 1982. Dene Self-Determination and the Study of Hunter-Gatherers in the Modern World, in Leacock, E. and Lee, R. (eds), Politics and History in Band Societies, Cambridge University Press, Cambridge.

Australian Bureau of Statistics, 1982. Persons and Dwellings in Local Government Areas and Urban Centres, Northern Territory, Cat. no. 2407.0, Canberra.

Basedow, H., 1904. Anthropological Notes made on the South Australian Government North-West Prospecting Expedition, 1903, Royal Society of South Australia, Transactions 28:12-51.

Basedow, H., 1914. Journal of the Government North-West Expedition (March 30th-November 5th) 1903, Royal Geographic Society of Australasia, South Australian Branch, Proceedings, 15 57-2 42.

Beard, J.S., 1981. Vegetation of Central Australia, in Jessop, J. (ed), Flora of Central Australia, Australian Systematic Botany Society, Reed, sydney.

Beard, J.S. and Webb, J., 1974. The Vegetation survey of Western Australia. University of Western Australia Press, $\overline{\text { Perth. }}$ 
Beaton, J., 1982. Fire and water: Aspects of Australian Aboriginal Management of Cycads, Archaeology in Oceania, 17(1) 51-58.

Birdsell, J.B., 1970. Local Group Composition among Australian Aborigines: a Critique of the Evidence from Fieldwork Conducted since 1930, Current Anthropology 11(2) 1967:100-55.

Bolton, B.L. and Latz, P.K., 1978. The Western Hare-Wallaby Lagorchertes hirsutus in the Tanami Desert, Australian Wildlife Research 5, 285-93

Brady, M. and Palmer, K., 1984. Alcohol in the Outback, Monograph, NARU, ANU, Darwin.

Brokensha, P., 1978. The Pitjantjatjara and Their Crafts, Aboriginal Arts Board, Australia Council, Sydney.

Brokensha, P., 1977. Listen to the Dreaming: The Aboriginal Homelands Movement, Australian Natural History 19(4) 119-23.

Brokensha, P. and McQuigan, C., 1977. Listen to the Dreaming, in Australian Natural History, $19(4)$.

Burbidge, J., 1943. Ecological succession observed during regeneration of Triodior pungeus after burning, Royal Society of Western Australia, Journal, 28, 149-56.

Bureau of Meteorology, 1974. Temperature: Climatic Atlas of Australia, AGPS, Canberra.

Bureau of Meteorology, 1975. Evaporation: Climatic Atlas of Australia, AGPS, Canberra.

Camp, Scott, Furphy, Pty. Ltd., 1978. Ilpilly Qutstation Water Quality Report, St. Kilda Road, Melbourne.

Cane, S.B., 1984. Desert Camps. Unpublished PhD, thesis, Department of Prehistory, RSPaCS, ANU.

Cane, S.B. and Stanley, O.G.P., Plants of Use to Aborigines in the Central and Western Deserts, CSIRO, in press.

Central Land Council, 1981-82. Annual Report, Alice Springs.

Carnegie, D. W., 1898. Spinifex and Sand, Pearson, London.

Chappell, J. and Thom, B., 1977. Sea Levels and Coasts, in Allen, J, Golson, J. and Jones, R. (eds), Sunda and Sahul, Academic Press, London.

Chippendale, G.M., 1963. Pasture degeneration in Central Australia, Journal of the Australian Insitute of Agricultural Research, 29 84-9.

Cogger, H.G., 1983. Reptiles and Amphibians of Australia, Reed, Sydney.

Coombs, H.C., 1974. Decentralisation Trends Among Aboriginal Communities. Search, 5(4) 135-43. 
Coombs, H.C., 1978a. Aboriginal Nutrition and the Ecosystems of Central Australia: Summing Up, Aboriginal Nutrition, 4, 1-4.

Coombs, H.C., 1978b. Some Aspects of Development in Aboriginal Communities in Central Australia, CRES working paper, CRES, ANU, Canberra.

Coombs, H.C., 1979. The Future of the Outstations Movement. CRES working paper, CRES, ANU, Canberra.

Coombs, H.C. and Stanner, W.E.H., 1974. Report on visit to Yuendumu and Hooker Creek, AGPS, Canberra.

Coombs, H.C., Dexter, B.G. and Hiatt, L.R. 1980. The Outstation Movement in Aboriginal Australia, AIAS Newsletter (14) 16-23.

Coombs, H.C., Brandl, M.M. and Snowden, W.E., 1983. A Certain Heritage. CRES monograph, CRES, ANU, Canberra.

Cousins, D. and Nieuwenhuysen, J., 1984. Aboriginals and the Mining Industry, George Allen and Unwin, Sydney.

Cundy, B., 1980. Australian Spear and Spear-Thrower Technology, Unpublished MA thesis, ANU, Canberra.

Dachs, G., 1981. A Choice of Futures, Methuen, Toronto.

Davidson, A.A., 1905. Journal of Explorations in Central Australia by the Central Australian Exploration Syndicate Limited, Government Printer, Adelaide.

Dean, B. and Carell, V., 1956. Dust for the Dancers. Ure Smith, Sydney.

Denny, M., 1983. Animals - native and feral, in Messer, J. and Mosley, G. (eds), What Future for Australia's Arid Lands? Australian Conservation Foundation, Melbourne.

Department of Community Development, 1983. Outstation funding for Kintore, Papunya, Yuendumu and Docker River Outstations, Darwin.

Department of Community Development, 1984a. Water quality reports supplied by DCD, Darwin.

Department of Community Development, 1984b. Outstations profiles for Docker River compiled during visits 14-18 May, Darwin.

Department of Health, 1980. Desirable Quality for Drinking Water in Australia, AGPS, Canberra.

Department of Primary Production, 1984. Northern Territory Primary Production statistics, 1982-83, Darwin.

Doran, J.C., Turnbull, J.W., Boland, D.J. and Gunn, B.V., 1983. Handbook on Seeds of Dry-zone Acacias, Division of Forest Research, CSIRO, Canberra.

Downey, J., 1980. The 'Outstations' or 'Homelands' Movement, Unpublished paper. AIAS, Canber $\overline{r a}$. 
Duguid, C., 1972. Doctor and the Aborigines, Rigby, Adelaide.

Edwards, R., 1966. The Need for Preservation of Aboriginal Cave Art, Royal Geographical Society of Australasia, South Australian Branch, Proceedings, 67 9-19.

Elkin, A.P. 1967. Reaction or Interaction: A Food Gathering People and European Settlement in Australia, in Bohannan, P. and Plog, F. (eds), Beyond the Frontier: Social Process and Culture Change, Natural History Press, Garden Ci

Flood, J., 1983. Archaeology of the Dreamtime, Collins, Sydney.

Frith, H.J., 1978. Wildlife resources in Central Australia, in Hetzel, B.S. and Frith, H.J. (eds), The Nutrition of Aborigines in Relation to the Ecosystem of Central Australia, CSIRo, Melbourne.

Frith, H.J. and Calaby, J.H., 1969. Kangaroos, Cheshire, Melbourne.

Fry, H.K., 1933. Body and Soul: A study from western Central Australia, Oceania, $3(3) \quad 247-56$.

Gee, L.C.E., 1911. General Report on the Tanami Gold-fields and District (North-Western Australia), Geologícal Dept., Adelaide.

Gerritsen, R., 1982. Outstations, differing interpretations and policy implications, in Loveday, P. (ed.), Service Delivery to Outstations. Monograph, NARU, ANU, Darwin.

Giles, E., 1889. Australia Twice Traversed, Samson Low, Marston, Searle and Rivington, London. (Facsimile edition Macarthur Press Sydney).

Gould, R.A., 1969. Subsistence Behaviour Among the Western Desert Aborigines of Australia, Oceania 39(4) 253-74.

Gould, R.A., 1970. Spears and Spear Throwers of the Western Desert of Australia, American Museum Novitates, 2403, 1-43.

Gould, R.A., 1971. The Archaeologists as Ethnographers in World Archaeology 3, 143-77.

Gould, R.A., 1980. Living Archaeology, Cambridge University Press, Cambridge.

Gosse, W.C., 1874. W.C. Gosse's Explorations, 1873: Report and Diary of Mr: W.C. Gosse's Central and Western Exploring Expedition, 1873 , Government Printer, Adelaide.

Gregory, A.C., 1969. Journals of Australian Explorations, AGPS, Canberra, (facsimilie of $188 \overline{4 \text { edition). }}$

Griffin, G.F. and Lendon, G., 1979. A Report on Visits through Three Aboriginal Homelands in Central Australia, Division of Land Resources Management, CSIRO, Perth.

Hall, N., Wainwright, R.W. and Wolf, L.J., 1981. Summary of Meteorological Data in Australia, Divisional Report 6, CSIRO, Canber 
Hallam, S.J., 1979. Fire and Hearth, AIAS, Canberra.

Hart, B.T., 1974. A Compilation of Australian Water Quality Criteria. Australian Wate $\bar{r}$ Resources council Technical Paper No.7, AGPS, Canberra.

Haynes, C.D. 1982. Man's Fire Stick and God's Lightning: Bushfire in Arnhem Land. 52nd AnzaAs Congress, Section 25A, Sydney, May.

Heathcote, R.L., 1983. The Arid Lands: Their Use and Abuse, Longman, London.

Hilliard, W.M., 1968. The People in Between: the Pitjantjatjara People of Ernabella, Hodder and stoughton, London.

Hughes, P.H. and Sullivan, M.E., 1981. Aboriginal burning and late Holocene geomorphic events in eastern NSW, Search, 12, 277-78.

Industries Assistance Commission, 1982. Bovine Brucellosis and Tuberculosis Eradication Campaign, Report, No.297, AGPS, Canberra.

Jessop, J., 1981. Flora of Central Australia, The Australian Systematic Botany Society, Reed, sydney.

Jones, R.M. 1969. Fire Stick Farming. Australian Natural History, 16, 22428.

Jones, R.M., 1970. Tasmanian Aborigines and Dogs. Mankind 7, 256-71.

Kalotas, A. 1984. Botanical information, in Coombs, H.C., Brand1, M.M. and Snowdon, W.E., Certain Heritage, Appendix 8, CRES, ANU, Canberra.

Kershaw, A.P., 1981. Quaternary Vegetation and Environments, in Keast, A. (ed.), Ecological Biogeography of Australia, Junk, The Hague.

Kesteven, S.L., 1978. A Sketch of Yuendumu and its Outstations, Unpublished thesis, CRE $\bar{S}, \overline{A N U}$, Canberra.

Kimber, R., 1976. Beginnings of Farming? Some Man-Plant-Arrival Relationships in Central Australia, Mankind 10(3) 142-50.

Kimber, R., 1977. Aboriginal Organisation - and Examination of Some Potential Problem Areas, Aboriginal Nutrition 3, 2-4.

Kimber, R., 1982. Walawurru, the Giant Eaglehawk: Aboriginal Reminiscences of Aircraft in Central Australia, 1921-1931, Aboriginal History 6(1) 49-60.

Kimber, R., 1982. The Pintupi and the Rintore Ranges, Kintore review, unpublished paper, DAA, Alice Springs.

Kimber, R., 1983. Future land use trends and possibilities in Aboriginal land use, in Messer, J., and Mosley, G. (eds), What Future for Australia's Arid Lands?, Australian Conservation Foundation. Melbourne.

Kimber, R., 1983. Black Lighting, Aborigines and Fire in Central Australian and the Western Desert, Archaeology in Oceania 18(1) 38-45. 
Kolars, J., 1966. Locational Aspects of Cultural Ecology: the Case of the Goat in Non-Western Agriculture, in Geological Review, 56.

Last, M., 1978. The Ernabella Community and its development. In Herzel, B.S., and Frith, H.J., (eds) The Nutrition of Aborigines in Relation to the Ecosystem of Central Australia, CSIRO, Me lbourne.

Latz, P.K., 1982. Bushfires and Bushtucker: Aborigines and Plants in Central Australia, unpubīished thesis, University of New England, Armidale.

Latz, P.K., 1983. The Ecological Implications of Current Trends in the Use of Aboriginal-Controlled Arid Lands, in Messer, J. and Mosley, G. (eds) What Future for Australia's Arid Lands? Australian Conservation Foundation, Melbourne.

Latz, P.K., and Griffin, G.F., 1978. Changes in Aboriginal Land Management in Relation to Fire and to Food Plants in Central Australia, in Hetzel, B.S., and Frith, H.J., The Nutrition of Aborigines in Relation to the Ecosystem of Central Australia, CSIRO, Meibourne.

Laut, P.: et al, 1977. Environments of South Australia, Province 8 , Northern Arid, Division of Land Use Research, CSIRO, Canberra.

Layton, R., and Rowell, M., 1979. Ayers Rock = Mt Olga National Park and Lake Amadeus Traditional Land Claim, CLC, Alice Springs.

Lee, R.B., 1979. The Kung San: Men, Women and Work in a Foraging Society, Cambridge University Press, Cambridge.

Long, J.P.M., 1957. Pastoral report, unpublished report, November, DAA.

Long, J.P.M., 1964. Papunya: Westernisation in an Aboriginal Community, in Reay, M.) (ed.) Aborigines Now: New Perspectives in the study of Aboriginal Communities, Angus and Robertson, Sydney.

Long, J.P.M., 1970. Change in an Aboriginal Community in Central Australia, in Pilling, A.R. and Waterman, R.A., (eds) Diprotodon to Detribalization: Studies of Change Among Australian Aboriginals. Michigan State University Press, East Lansing.

Long, J.P.M., 1971. Arid Region Aborigines: The Pintubi, in Mulvaney, D.J. and Golson, J., (eds) Aboriginal Man and Environment in Australia, ANU Press, Canberra.

Love, J.R.B., and Balfour, L.J., 1968. Report on Ernabella Mission, in Hilliard, W.M.' The People In Between: the Pitjantjatjara people of Ernabella, Hodder and Stoughton, London.

Low, W., 1984. Summary of $\frac{\text { Lands }}{\text { Department }}$ Files on Chilla weli,

MacFarlane, w.v., 1978. Aboriginal Desert Hunter/Gatherers in Transition, in Hetzel, B.S. and Frith, H.J., (eds) The Nutrition of Aborigines in Relation to the Ecosystem of Central Australia, CSIRO, Melbourne.

Macknight, C.C., 1972. Macassans and Aborigines, Oceania 42:283-321. 
Maggs, D.H., 1978. The potential for horticulture in Central Australia, in Hetzel, B.S. and Frith, H.J. (eds) The Nutrition of Aborigines in Relation to the Ecosystem of Central Australia, CSIRo, Melbourne.

McKay, D., 1926. Report on the McKay Exploring Expedition C.A., Australian Archives CRS $\overline{\mathrm{A} 431} \mathrm{I}$ tem $\overline{47 / 1} \overline{640 .}$

Meehan, B., 1977. Man Does Not Live by Calories Alone, the Role of Shellfish in a Coastal Cuisine, in Allen, J., Golson, J. and Jones, R. (eds) Sunda and Sahul, Academic Press, London.

Meehan, B., 1979. Australian Aboriginal Outstation Movement: Return to the Past of Preparation for the Future, paper from 14th Pacific science Congress, USSR. Department of Prehistory RSPacSANU, Canberra.

Meggitt, M.J., 1962. Desert People: a Study of the Walbiri Aborigines of Central Australia. Angus and Robertson, sydney.

Midgely, S.J. and Gunn, B.U., 1983. Seed Collection for International Provenance Trials of Acacia aneura, unpublished paper, Division of Forest Research, Cs TRo, Canberra.

Mitchell, T.L., 1848. Journal of an Expedition into the Interior of Tropical Australia, Longmans, Brown, Green and Longmans, London.

Mollison, B.C., and Holmgren, D., 1978. Permaculture one, Ealing, England.

Mollison, B.C., 1984. Permaculture 2, Tagari, Stanley, Tasmania.

Morice, R.D., 1978. Women Dancing Dreaming: The Homelands Movement, in Hetzel, B.S., and Frith, H.J., (eds) The Nutrition of Aborigines in Relation to the Ecosystem of Central Australia. CSIRo, Melbourne.

Moyle, R., 1979. Pintubi Songs, AIAS, Canberra.

Mulvaney, D.J., 1975. The Prehistory of Australia, Rev. ed. Penguin, Sydney.

Myers, F.R., 1976. To Have and to Hold: a Study of Persistence and Change

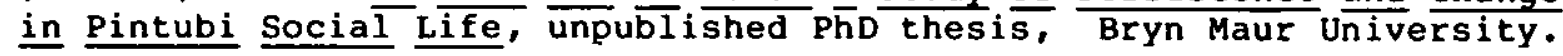

Myers, F.R., 1980(a). A Broken code: Pintubi political theory and contemporary social life, Mankind, $12(4) 311-26$.

Myers, F.R., 1980(b). The cultural basis for politics in Pintubi life, Mankind 12(3) 197-214.

Nathan, P., and Japanangka, D. 1983. Settle Down Country, Kibble Books, Melbourne.

Northern Territory Tourist Commission, 1984. Initiatives for Tourism Facilities, Darwin.

Nortman, D.L., and Fisher, J., 1982. Population and Family planning Programs: a Compendium of Data, Population Council, New York. 
O'Connell, J., and Hawkes 1981. Alyawara Plant Use and Optimal Foraging Theory, in winterhalder, B. and Smith, E.A., (eds) Hunter-Gatherer Foraging Strategies: Ethnographic and Archaeological Analyses, University of chicago Press, Chicago.

O'Connell, J.F., Latz, P.K. and Barnett, P., 1983. Traditional and Modern Plant Use Among the Alyawara of Central Australia, Economic Botany. 37(1) 80-109.

Palmer, K., 1983. 'Owners' and 'Managers': Ritual Co-operation and Mutual Dependence in the Maintenance of Rights to Land, Mankind 13(6) 517-26.

Pearse, M., 1985. The Tourist Industry of Central Australia: a Regional Application of Input-Output Analysis, in Loveday, P. and WadeMarshall, D. (eds): People and Economy in the North, Monograph, NARU, ANU, Darwin.

Penny, D., Davis, K., and Hunter, J., 1977. Papunya: History and Future Projects, report for DAA.

Perry, R.A., 1960. Pasture Lands of the Northern Territory, Australia, Land Research Series No.5, CSIRO, Melbourne.

Perry, R.A., (ed.) 1962. General Report on Lands of the Alice springs

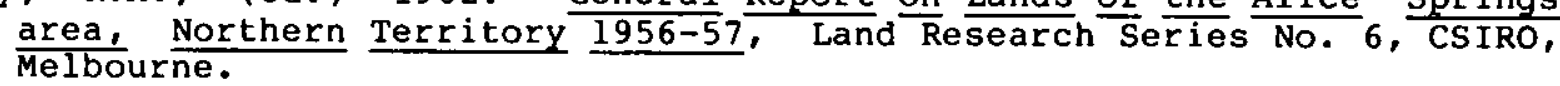

Peterson, N., 1976. Ethno-archaeology in the Australian Iron Age. In Sieveling, G., Longworth, I.H., and Wilson, K.E., (eds) problems in Economic and Social Archaeology, Duckworth, London.

Peterson, N., 1978. The Traiditional Pattern of Subsistence, in Hetzel, B.S., and Frith, H.J.' The Nutrition of Aborigines in Relation to the Ecosystem of Central Australia, CSIRO, Melbourne.

Peterson, N., Wild, S., and McConnell, P., 1976. A Claim to Areas of Traditional Land by the Walpiri and Kartangaruru, $C \frac{1}{L} \frac{C l a i n}{\text { Alice }}$ springs.

Phillpot, S., 1985. Aspects of Labour Usage in Aboriginal Operated cattle Activities in Central Australia, in Loveday, P., and Wade-Marshall, D. , (eds) Economy and People in the North, Monograph, NARU, ANU, Darwin.

Peile, A.R., 1980. Preliminary Notes on the Ethnobotany of the Gugadja Aborigines at Balgo, Western Australia, Western Australian Herbarium
Research notes $1(3)$ 59-64.

Robin, D., 1979. Papunya: Seeking a Solution, in Aboriginal News 3(6) 9.

Shaw, L., 1983. Utopia Land Resources: Their Condition, Utilisation and Management, Department of Primary Production, Alice Springs.

Silberbauer, G.B., 1971. Ecology of the Ernabella Aboriginal Community, in Anthropological Forum 3(1) 21-36. 
Singh, G., Kershaw, A.P., and Clark, R., 1981. Quaternary Vegetation and Fire History in Australia, in Gill, A.M., Groves, R.H. and Noble, I.R., (eds) Fire and the Australian Biota, Australian Academy of Science, Canber ra.

Slater, P., 1970-1974. A Eield Guide to Australian Birds. Vols 1 and 2, Rigby, Adelaide.

Sommes, and Mitchell, 1976. Report on visits to Papunya, September 3rd, DAA.

Spencer, W.B., and Gillen, F.J., 1912. Across Australia, MacMillan, London.

Stanley, O.G.P., 1976. Aboriginal communities on cattle stations in Central Australia, in Australian Economic Papers, 15, 158-70.

Stanley, O.G.P., 1982. Royalty Payments and the Gagudju Association, in Loveday, P., (ed.) Service Delivery to Remote Communities, Monograph, NARU, ANU, Darwin.

Stanley, O.G.P., 1983. An Aboriginal Economy: Nguiu, Northern Territory, Monograph, NARU, ANU, Darwin. Australia Research Unit, Monograph.

Stanley, O.G.P., 1985(a). Economic Development Problems in Remote Aboriginal Communities, in Loveday, P., and Wade-Marshall, D., (eds) Economy and People in the North, Monograph, NARU, ANU, Darwin.

Stanley, O.G.P., 1985(b). The Mission and Peppimenarti: An Economic Study of Two Daly River Aboriginal Communities, Monograph, NARU, ANU, Darwin.

Stanley, $0 .$, forthcoming. The Economy of Mornington Island, Monograph, NARU, ANU, Darwin.

Stead, G., 1982. Kintore Review, unpublished report, DAA, Alice Springs.

Strehlow, T.G.H., 1947. Aranda Traditions, Melbourne University Press, Melbourne.

Strehlow, T.G.H., 1968. Forward, in Hilliard, W.M., The People In Between. Hodder and Stoughton, London.

Stuart, J.M., 1863. Explorations Across the Continent of Australia with charts, 1861-62, Bailliere, Melbourne.

Sweeney, G., 1947. Food Supplies of a Desert tribe, Oceania, 17(4) 289-99.

Terry, M., 1931. Hidden Wealth and Hiding People, Putnam, London.

Thomas, S., and Corden, M., 1977. Metric Tables of Composition of Australian foods, AGPS, Canberra.

Thomson, D.F., 1975. Bindibu Country, Nelson, Melbourne.

Tietkens, W.H., 1891. Journal of the Central Australian Exploring Expedition, 1889, Government Printer, Adelaide.

Tindale, N.B., 1935. Initiation among the Pitjandjara Natives of the Mann and Tomkinson Ranges in South Australia, Oceania, 6(2) 199-224. 
Tindale, N.B., 1953. On some Australian Cossidae including the Moth of the Witjuti Witchetty Grub, Transaction of the Royal Society of South Australia, 76, 56-65.

Tindale, N.B., 1965. Stone implement making among the Nakako, Ngadadjara and Pitjandjara of the Great Western Desert, Records of the South Australian Museum, 15(1) 131-64.

Tindale, N.B., and Hackett, C.J., 1933. Preliminary Report on Field Work among the Aborigines of the North West of South Australia. Oceania, 4(1) 101-5.

Tonkinson, R., 1974. The Jigalong Mob: Aboriginal Victors of the Desert Crusade, Cummings, $\overline{\text { Cal }} i$ fornia.

Toohey, J., 1979. Uluru (Ayers Rock) National Park and Lake Amadeus National Park Land Claim, AGPS, Canberra.

Toyne, P., and Vachon, D., 1984. Growing Up the Country: the Pitjantjatjara Struggle for their Land, McPhee Gribble, Melbourne.

Walker, B., 1982. Water and related services to remote communities, in Loveday, P., (ed.) Service Delivery to Outstations, Monograph, NARU, ANU, Darwin.

Wallace, P.N., and Wallace, N., 1977. Killing Me Softly: The Destruction of a Heritage, Nelson, Melbourne.

Warburton, P.E., i875. Journey Across the Western Interior of Australia, Sampson, Marston, Low and Searle, London.

White, S.A. 1915. Aborigines of the Everard Range. Transactions of the Royal Society of South Australia, 39(1) 725-32.

Wilkinson, L., 1981. The Development of the Aboriginal Outstation Movement in the N.T, BA Hons. Thesis, LaTrobe University, Me 1bourne.

Willis, J.H., 1981. The History of Botanical Investigation in Central Australia, in Jessop, J., (ed.) Flora of Central Australia, Australian Systematic Botany Society, Reed, Sydney.

Winfield, C., 1982. Bush Tucker, Mimili Aboriginal School.

World Health Organisation, 1981. Guidelines for Drinking Water Quality, World Health Organisation, Geneva.

Yengoyan, A., 1968. Demographic and Ecological Influences on Aboriginal Australian Marriage Sections, in Lee, R.B. and De Vore, L., (eds) Man the Hunter, Aldine, Chicago.

Young, E., 1981. Tribal Communities in Rural Areas, Development Studies Centre, ANU, Canberra.

Young, E., 1982. Outstations, 1981: The Wider Setting, in Loveday, P., (ed.) Service Delivery to Outstations, Monograph, NARU, ANU, Darwin.

Young, E., 1984. Outback Stores: Retail Services in North Australian Aboriginal Communities, Monograph, NARU, $\overline{\text { ANU, Darwin. }}$

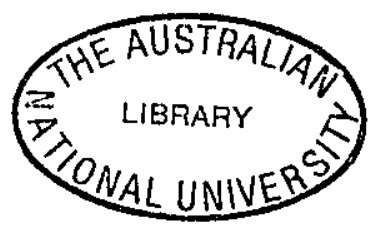


is

1.

13 3525?

I

- $C$

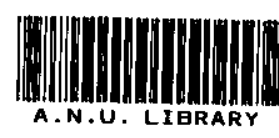

$\therefore$

. $i$

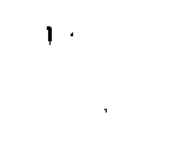

$\|_{R Y}$

i

i

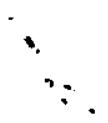




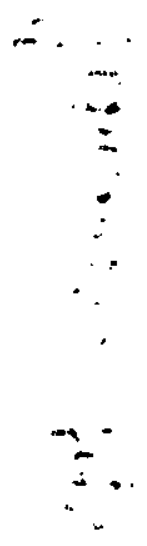

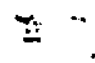

